\title{
Entertaining Prospects: Garrison and Gold Town Theatre in New Zealand c.1850-1870
}

Maggie R. Blackburn

\begin{abstract}
A thesis
submitted to Victoria University of Wellington

in fulfilment of the requirements for the degree of

Master of Arts in History
\end{abstract}

Te Herenga Waka Victoria University of Wellington 2021 



\begin{abstract}
Theatres established throughout New Zealand during the mid-nineteenth century offered colonial audiences, even those in smaller settlements, access to a vast array of live performance and popular dramatic amusements. Examining several garrison and gold towns and experimenting with the use of various digital quantitative and spatial methodologies, this thesis explores the interplay between playhouses and colonial audiences. The study focuses particularly on the extent to which theatre operated as a vehicle and arena for the spread of Anglo culture, performance of gendered work, and the production or degradation of colonial respectability.

Providing collective excitement, diversion, and respite from otherwise monotonous or solitary activities, theatres were significant features of civic society and cultural life between 1850 and 1870 . Garrison amateur dramatics in Auckland and New Plymouth performed by soldiers stationed in New Zealand during the quieter 1850s proved that there were prospective constituencies of theatregoers with both appetite and appreciation sufficient to support regular theatrical amusements. Theatre expanded as gold fever spread across Otago and then the West Coast during the 1860s. From 1862, Dunedin's theatre scene exploded as gold attracted diggers and auxiliaries from far and wide.
\end{abstract}

Theatres were prominent markers of civic development. Whether in transient gold town settlements or commercial urban centres, playhouses shared a common repertoire introduced by performers and managers from across the Anglo-world. Performing contemporary plays from Britain, Australia, and North America, theatre companies in colonial New Zealand brought with them experience and reputations cultivated on touring circuits elsewhere. Analysing how these theatre people acted as conduits of cultural transmission, the study utilises network and spatial analyses to demonstrate how theatre provided access to contemporary theatre culture and thus situated playgoers within a constituency of cultural consumers throughout a vast Anglo-theatre network.

The thesis also investigates the characteristics of theatres as colonial workplaces. Focusing predominantly on commercial theatre, the study explores how, in operating outside broader social conventions, playhouses enjoyed flexibility in defining acceptable work. Quantitative analyses of house size data highlighting the fluctuation of audiences, and debtors' petitions filed by theatre professionals, demonstrate the economic precarity of theatre business. Nonetheless, theatre women enjoyed greater freedom and opportunity for advancement than in other professions. The analysis demonstrates the uneven extent to which gender was used as grounds for criticism in New Zealand.

Colonial settlements were sensitive to ideas of reputation and progress. As public spaces, theatres featured heavily in contemporary discussion and debate which interpreted venues and repertoire as variously civilizing and corrupting. Alongside amusement and leisure, playhouses were also sites of commerce, social mixing, heightened emotion, drunkenness, and disorder. Assessing how theatre and theatregoing played into a broader discourse of respectability reflecting societal anxiety over colonial reputation, the study argues that theatres were hotly debated because public entertainments were taken to reflect the general character of colonial inhabitants.

\title{
NOTE:
}

This thesis was completed between 1 April 2020 and 31 March 2021 during which time various restrictions were in place to respond to the Covid-19 pandemic. New Zealand was in Level 4 lockdown from 26 March - 28 April 2020. Level 3 restrictions, which impacted access to research repositories, were in place from 29 April - 13 May 2020. 


\section{Acknowledgements}

Thanks must go, first and foremost, to my supervisor Professor Charlotte Macdonald for her energy, constructive feedback, and continual encouragement to experiment and push ideas to make this thesis the best version of itself. Thank you for your incredible support, wisdom, and enthusiasm for this colourful theatrical world.

To the rest of the History programme - especially Beth, Tommy, and Lydia - thank you for the entertaining, supportive, and collegial environment which made Old Kirk the best place to work.

I owe an enormous debt of gratitude to Brenda Joyce and Julia Paton for the support they provided by donating the Jack Pearce Scholarship in New Zealand or English History and the Buchanan Scholarship in New Zealand History and Society. Their generosity provided the financial support necessary to complete this thesis. Research trips were funded by the Victoria University of Wellington Faculty of Humanities and Social Sciences Joint Research Committee.

To staff at Hokitika Museum, the Hocken Library, and the Dunedin branch of Archives New Zealand - thank you for your assistance in locating sources even when some proved elusive. An especial thank you to Lynn Benson who offered both enthusiastic conversation and generous hospitality. Thanks also to Phuong Do, for the same, and continually reminding me that my trip to Dunedin coincided with the coldest week of the year.

To my parents Kirsty and Phil, and my brother Ian, for reading drafts, cooking dinners, and everything in between. Thank you, you're good. Also, to Kaley, for your ongoing enthusiasm, encouragement, and genuine excitement at the prospect of proof-reading.

A nod of thanks to my immediate and extended Wellington theatre whanau, both backstage and front, and to Bern McCabe who provided unwitting inspiration by observing that, 'it's not the bricks and mortar that make the theatre' but 'the people who inhabit the theatre and love it into being.'

Finally, to my Nana Vi who lived for the magic of the stage. I will love you always. 


\section{Contents}

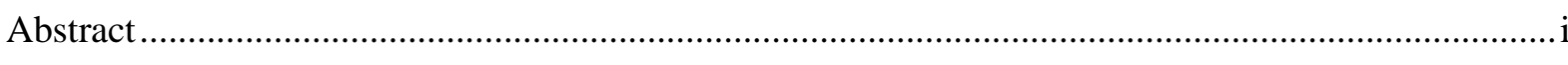

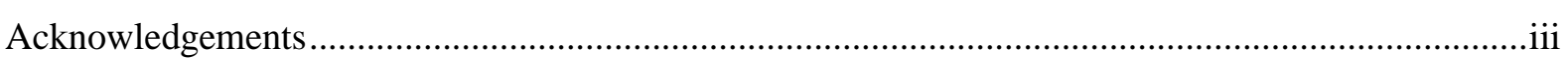

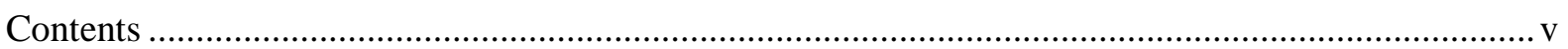

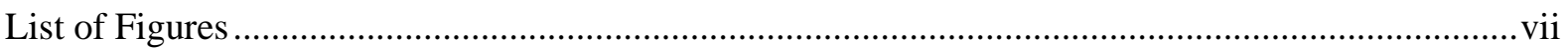

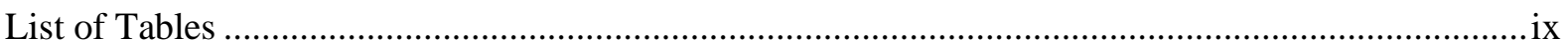

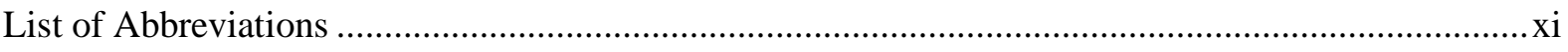

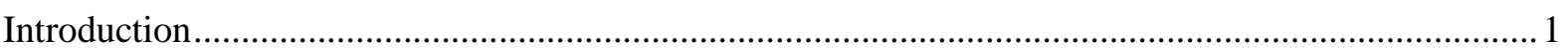

Theatre, Culture, and Colonisation …................................................................................... 7

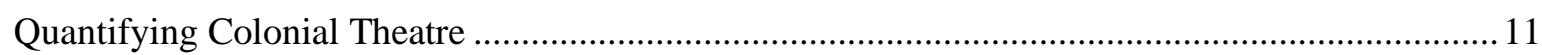

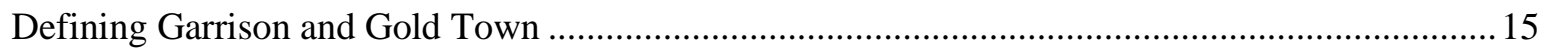

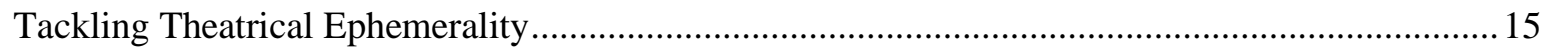

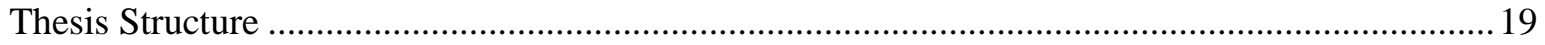

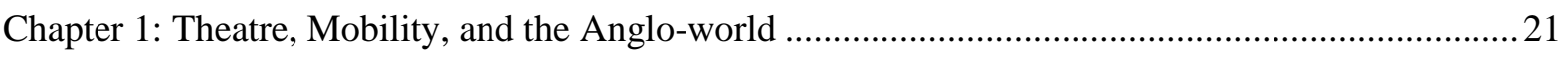

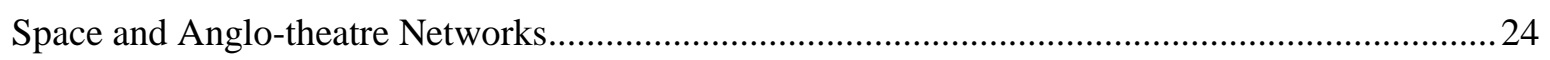

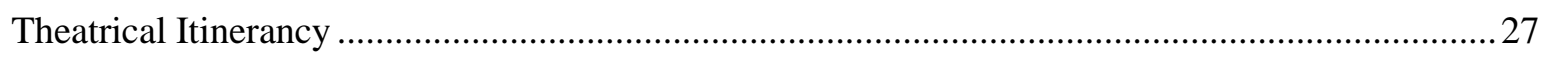

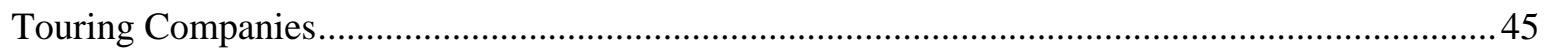

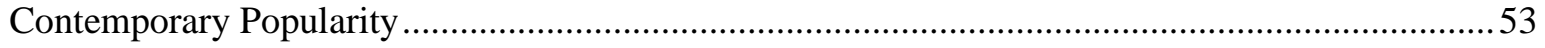

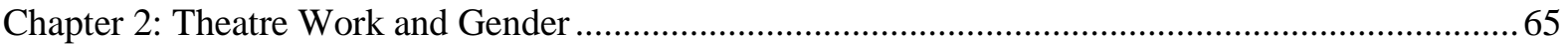

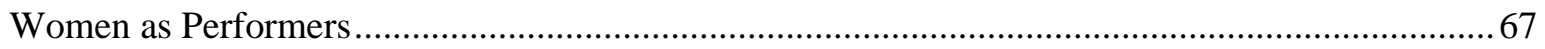

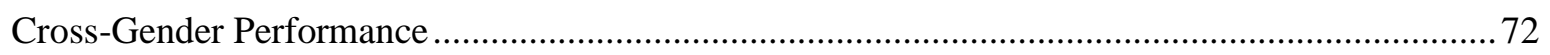

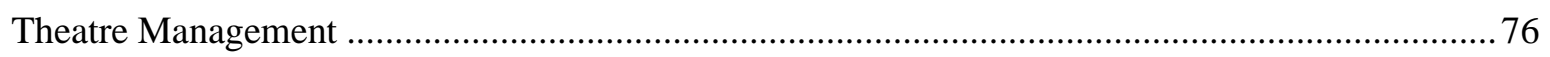

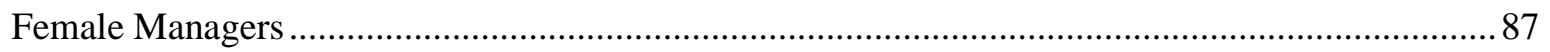

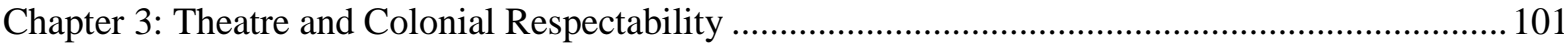

Victorian Respectability and Colonial Perceptions of Theatre ..................................................... 117

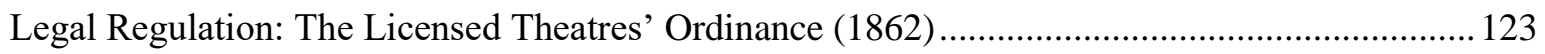

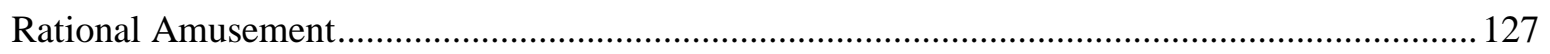

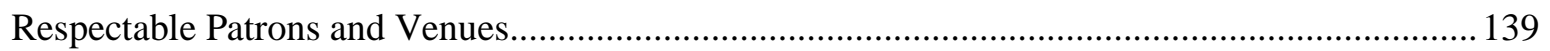

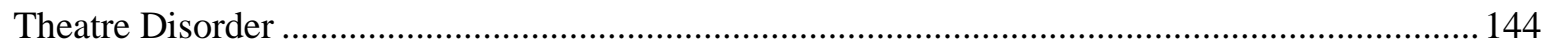

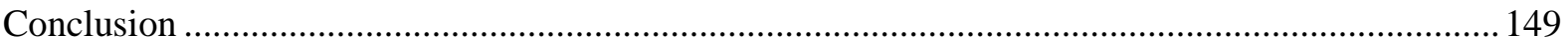

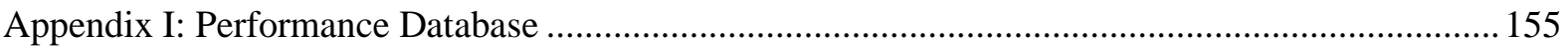

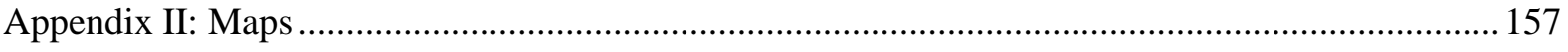

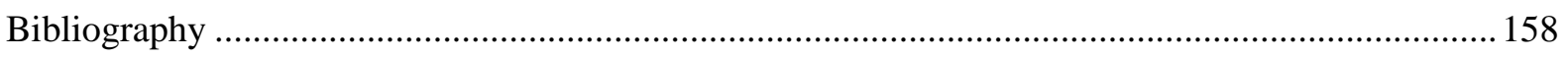

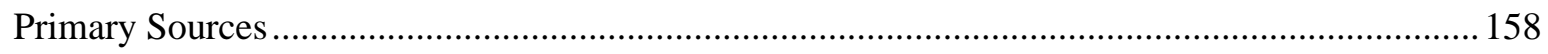

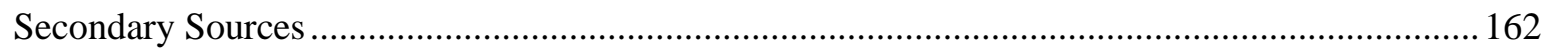




\section{List of Figures}

Figure

Page

$1.1 \quad$ Settlements with Theatre Venues $1840-69$

Amateur Dramatic Societies 1840 - 70

Dolly Green's Seven Ages of Woman Tour 1869 - 70

Tom Fawcett's New Zealand Engagements 1862 - 1867 
Figure

Page

4.4

Genre Analysis: New Plymouth

121

4.5

Genre Analysis: Queenstown

122

4.6

Genre Analysis: Hokitika

123

4.7

Genre Analysis: Greymouth

124 


\section{List of Tables}

Table Page

$1 \quad$ Lyster's Royal Italian and English Opera Company Itinerary 50

$2 \quad$ Lenton Troupe Itinerary 53 


\section{List of Abbreviations}

AJHR

ANZ

ATL

AWMM

DSC

$G R A$

$L W M$

NLA

NZJH

$O D T$

OW

SF

TH

WCT
Appendices to the Journal of the House of Representatives

Archives New Zealand

Alexander Turnbull Library

Auckland War Memorial Museum

Daily Southern Cross

Grey River Argus

Lake Wakatip Mail

National Library of Australia

New Zealand Journal of History

Otago Daily Times

Otago Witness

San Francisco

Taranaki Herald

West Coast Times 


\section{Introduction}

Visitors to Shadrach Jones' Horse Bazaar on the morning of 5 February 1862 were surprised to discover the auction space in the yard behind Dunedin's Provincial Hotel bustling with activity. Overnight, the place had been 'invaded by a little army of carpenters' with workmen pulling up floorboards and hammering from perches in the rafters to make additions overhead. 'It was almost', the Otago Daily Times noted, 'as if the place had been converted into a carpenters' shop or builders' yard.' ${ }^{1}$ In reality, preparations were underway for the arrival of a ship from Melbourne carrying members of Dunedin's first professional theatre company.

The renovations were being made to allow the building to serve dual purposes - continuing its function as a horse sale yard by day and transforming by night into a venue for theatrical amusement. The Otago Daily Times observed the developments with interest:

This novel idea suggests some curious speculations - as, for instance, will the horses be removed from the premises or merely shut up in their stables; and, if the latter, will they - as compensation for being deprived of their natural rest - be allowed to turn their heads where their tails should be, and see the performance? Or, if the horses are turned out, will their 'stalls' be converted into theatre stalls, and the 'loose boxes' correspond with the dress circle? And, in such a case, will the smell of the stable add a peculiar zest to the performance? ${ }^{2}$

The editors were amused but felt, despite their witty inquiries, that the novel proposition was a good one. As alterations neared completion, attention turned to the arrival of the troupe and the prospect of having 'the legitimate drama introduced into Dunedin under circumstances more promising than could well have been anticipated. ${ }^{3}$

By the end of February, the Bazaar had been skilfully transformed, with 'a series of mechanical contrivances', into a first-class colonial theatre. ${ }^{4}$ The house was decorated by an artist of Australian fame noted for his work on the Princess Theatre and Theatre Royal, two of Melbourne's principal playhouses. A detailed proscenium arch culminated in a design of cupids and flowers, coloured and gilded to contrast the surrounding Corinthian pillars and the front of the stage which was characterised "more by a chaste simplicity than by any attempt at gaudy display. ${ }^{5}$ An elaborate drop scene had been ordered, and a green baize curtain cloaked the stage. Two chandeliers and fifty lamps lit the auditorium, while kerosene lamps with reflectors threw floodlights on the performers. Although measuring 32 feet by 22 feet, the stage could be folded up to allow passage through the centre of the building by day.

\footnotetext{
${ }^{1}$ Otago Daily Times (ODT), 6 February 1862, p.2.

2 ibid.

${ }^{3}$ ODT, 26 February 1862, p.5 supp.

${ }^{4}$ ibid.

5 ibid.
} 
Christening the new establishment the Royal Princess Theatre, Jones set about promoting the horse bazaar's transformation and the theatre's name was swiftly painted and illuminated on the side of the building.

On 4 March, after some delay, the company arrived. The next evening, the Princess Theatre opened to the public with a double-bill programme comprising William Murray's Scottish drama Cramond Brigg and That Rascal Jack, a farce by English playwright Thomas L. Greenwood. ${ }^{6}$ The new theatre was capable of seating upwards of 1000 people, the majority in the pit and stalls with 250 seats in the highest-priced boxes stretching along either side of the auditorium. With the horses concealed behind canvas screens, a crowd of more than 900 gathered on opening night as Dunedin welcomed a brand of entertainment which the press hoped would become a 'permanent accession' to the presently limited repertoire of public amusement. Within less than a year, theatre cemented itself as a prominent feature of social life in goldrush Dunedin as the Princess and Dunedin's second professional playhouse, the Theatre Royal, staged more than 230 productions.

Theatre expanded as gold fever spread across Otago and then the West Coast throughout the remainder of the 1860s. The lucrative prospect of new goldrush audiences eager to spend their discretionary income attracted contemporary stars, many of whom had established their reputations touring the goldfields of Victoria or California. As gold towns materialised and expanded at great pace, so too did their capacity for professional entertainment. While many theatres were simple performance spaces connected to hotels, others developed into grand enterprises. Hokitika, for example, a mere collection of temporary structures in early 1865 , boasted its own 1400 -seat opera house by the beginning of 1866. Between 1850 and 1870, throughout the colony, theatres became significant civic features of society and cultural life, providing collective excitement, diversion, and respite from otherwise monotonous or solitary activities.

Theatres were markers of civic progress which provided an indication of a settlement's progression beyond the provision of bare necessities required for survival. In colonial towns particularly sensitive to measures of progress and reputation, respectable venues for entertainment were often much prized. John Logan Campbell, visiting San Francisco in 1851, wrote of the comparison between the California goldrush centre and the fledging social scene in Auckland, which he termed the 'Capital of Monotony." San Francisco, he noted, with 'shops, warehouses, inns, saloons, theatres and gambling houses', made one feel 'in the world, not expatriated as in the Antipodes. ${ }^{8}$ In 1863, a report on the Otago goldfields presented to the House of Representatives highlighted similarly pleasing progress of the settlement at Queenstown. 'Although only seven months old', the report noted, the town already consisted of 'several streets closely lined with numerous stores and hotels, with concert rooms and a

\footnotetext{
${ }^{6}$ ODT, 5 March 1862, p.5.

${ }^{7}$ Quoted in R.C.J. Stone, Young Logan Campbell, (Auckland: Auckland University Press, 1982), p.172.

${ }^{8}$ J.L. Campbell to Dr J. Campbell, 30 May 1851, quoted in Stone, p.171.
} 
theatre for the votaries of pleasure, and with churches for the service of the Deity. ${ }^{9}$ In Dunedin, the Princess Theatre had remedied a noted absence. In early January 1862, the press revived an old grievance when they commented on the unsatisfactory state of public entertainment and expressed a tentative hope that the void would soon be filled:

As regards amusements, there is a 'very plentiful lack' of anything of the kind; the only entertainment having been that of the San Francisco Minstrels, who have had a long and profitable campaign in Otago. We are promised, however, a series of theatrical entertainments by Mrs Foley's company. Doubtless the want of a theatre will have operated to some extent in deterring theatricals from visiting Dunedin. This want, we presume, will shortly be supplied by the enterprise of some of the spirited Victorian speculators, who have been attracted to these shores. ${ }^{10}$

The crowd which gathered at the Princess on opening night thus welcomed both a fresh brand of entertainment and a crucial milestone in the civic development of the settlement at large.

Two groups of men played an instrumental role in developing theatre in New Zealand. The first were soldiers of the British army stationed in the colony from the 1840s right through to 1870 who brought with them a tradition of military dramatics. Amateur dramatics were viewed by military elites as a productive means of alleviating boredom and combatting breakdowns in discipline which were most frequent during extended periods of inactivity or garrison duty. ${ }^{11}$ Studies of British troops garrisoned in North America in the decades after the American Revolutionary War have emphasised the influence of extended idle time on the development of amateur theatre. ${ }^{12}$ While the military presence in New Zealand was shorter and included significant periods of active combat, the soldiers of the $58^{\text {th }}$ and $65^{\text {th }}$ regiments stationed here during the quieter years of the 1850 s found time to devote to similar forms of social distraction. ${ }^{13}$ By 1850 , the $58^{\text {th }}$ regiment had woven itself into the fabric of social life in Auckland. ${ }^{14}$ Throughout the following decade, the theatre at Albert Barracks provided public amusement for civilian and soldier alike and the arrival of the $65^{\text {th }}$ regiment bolstered the military theatrical presence in other parts of the North Island. Energetic garrison theatres entertained audiences in Auckland and at Marsland Hill in New Plymouth on a regular basis. Similar entertainments, though on a smaller scale, were also staged by detachments of the $65^{\text {th }}$ in Napier and Whanganui.

\footnotetext{
9 'Report on the Otago Gold Fields', Appendices to the Journal of the House of Representatives (AJHR), 1863, Session I, D-06, p.12.

${ }^{10}$ Otago Witness $(O W), 11$ January 1862, p.5.

${ }^{11}$ Adam Davis, The Furthest Garrison: Imperial Regiments in New Zealand 1840-1870, (Solihull: Helion \& Company, 2019), p.90.

${ }^{12}$ Alex D. Boutilier, 'The Citadel on Stage: The rise and decline of garrison theatre in Halifax', MA thesis, Saint Mary's University, 2005, p.18; Jared A. Brown, 'A Note on British Military Theatre in New York at the End of the American Revolution', New York History, Vol.62, no.2, 1981, pp.177-187; Elinor Senior, 'The British Garrison in Montreal in the 1840s', Journal of the Society for Army Historical Research, Vol.52, no.210, Summer 1974, pp.111-127; Robert Vineberg, 'The British Garrison and Montreal Society 1830-1850', Canadian Military History, Vol.21, no.1, Winter 2012, pp.3-16; David Worrall, 'Theatre in the Combat Zone: The Military Theatricals at Philadelphia, 1778', Linguaculture, Vol.2, pp.11-22.

${ }^{13}$ Charlotte Macdonald, 'Woolwich to Wellington: From Settler Colony to Garrisoned Sovereignty', New Zealand Journal of History (NZJH), Vol.53, no.1, April 2019, pp.50-76.

${ }^{14}$ Una Platts, The Lively Capital, (Christchurch: Avon Fine Prints, 1971).
} 
The second group were gold-seekers who flooded into Otago and the West Coast during the 1860 s in pursuit of fortune and with a demand for amusement. From 1862, the influx of men enhanced the potential viability of professional entertainment first in the South Island and then further afield. Early gold towns were rough settlements populated predominantly by young, single, men - a captive audience for hotelkeepers and dance hall proprietors offering food, drink, and amusement. ${ }^{15}$ The diggers were followed by a vast assortment of actors and variety troupes many of whom had established themselves as goldfield entertainers in Victoria and California. Gold-seekers fundamentally challenged more structured, 'orderly', and familial forms of colonisation and settlement partly because they arrived as large groups of unattached and unsettled men but also because success on the goldfields was more commonly characterised by luck than hard work and dedicated application. ${ }^{16}$ Towns like Hokitika started life as masses of canvas tents and grew rapidly and haphazardly as the diggers were joined by merchants, publicans, and performers. ${ }^{17}$ Alcohol and gambling were popular leisure pursuits, and women were scarce. These tent towns, 'caused consternation' Barbara Brookes argues 'for those who had hoped for a land of settled families' but they also offered opportunity for many to capitalise on the comparatively loose social structure. ${ }^{18}$ By 1870 , the initial gold frenzy dissipated as towns throughout Otago and the West Coast emptied rapidly or settled into a more sedate pace of life.

Professional theatre in Otago emerged within a moment of collision which distinguished it from the experience in Auckland, Wellington, and much of the rest of the colony. The goldrush migrants who flooded the Free Church settlement at Dunedin had overwhelmed the Old Identity with 'footloose, single, drunken, whoring, gambling young men...beyond the reaches of the Kirk' who 'pursued pleasure unredeemed by moral purpose. ${ }^{19}$ Catering to the resulting demand for entertainment, theatre - itself threatening to poison the orderly Scottish settlement with vulgarity, spectacle, and frivolity expanded at great pace, under the ever-watchful eye of the Otago Provincial Council. Developing within the Otago World founded by Cargill and Burns, which was already grappling with the cultural shock of the goldrush, theatre was met with suspicion as well as excitement as measures were quickly put in place to regulate public amusements.

Despite preoccupation with gold-seeking and military routine, inhabitants of New Zealand's garrison and gold towns were also eager cultural consumers with an appetite for news, stories, and

\footnotetext{
${ }^{15}$ S.N. Brown, James Flanagan, and John McCormick in E.M. Story, 'Stories of the Gold Diggings: Collected from the Gold Diggers Settled in New Zealand', Ref: fMS-Papers-7868, Alexander Turnbull Library (ATL).

${ }^{16}$ David Goodman, Gold Seeking: Victoria and California in the 1850s, (St Leonard's: Allen \& Unwin, 1994); Christopher Herbert, 'Life's Prizes are by Labor Got: Risk, Reward, and White Manliness in the California Gold Rush', Pacific Historical Review, Vol.80, no.3, 2011, p.340.

${ }^{17}$ William and Mary Hay, 'Letters from William and Mary Hay, Hokitika', Ref: MS-Papers-3779, ATL; Caroline Chevalier, 'Chevalier, Caroline: A short description of a journey across the South Island of New Zealand from East Coast to West Coast and back from West to East Coast', Ref: MS-0143, Hocken Library, Dunedin, p.40; John Henry Watmuff, 'The journals of John Henry Watmuff - New Zealand extracts, 18611864/transcribed by Stephen Arnold (1861-1864(2006))', Ref: Misc-MS-2000, Hocken Library, Dunedin, p. $2 / 298$.

${ }^{18}$ Barbara Brookes, A History of New Zealand Women, (Wellington: Bridget Williams Books, 2016), p.93.

${ }^{19}$ Erik Olssen, A History of Otago, (Dunedin: John McIndoe Ltd, 1984), p.56.
} 
gossip. Providing information and entertainment first and foremost, newspapers and literature also allowed colonial inhabitants to retain and foster a sense of connection with places from which they were geographically separated. ${ }^{20}$ Reading and collective discussion of literary works offered colonists 'a reminder of civilization and social forms. ${ }^{21}$ J.E. Traue argues that print culture - newspapers, periodicals, and novels - also offered 'the most effective means' of retaining connection. ${ }^{22}$ Popular culture consumed through literature and print was, Traue suggests, a 'necessity of life' in remote settlements where 'cultural curiosity was stimulated by distance. ${ }^{23}$ Examining the development of theatre in the American West, Carolyn Eichin argues that, to some degree, being part of a theatre audience 'ameliorated a lack of community' in transient societies. ${ }^{24}$ Consumption of contemporary news and literature aided in maintaining and fostering links across empire and the wider Anglo-world. It is worth considering the extent to which theatregoing extended this agenda through collective experience which differed from reading by fostering both a sense of connectedness with other metropolitan and colonial populations and a stronger sense of more immediate community through the emotive atmosphere and experience of the auditorium.

As evidence of reading's importance, Traue highlights the speed with which access to print culture and literary material was achieved in gold town communities through the opening of subscription libraries. These services were, he argues, one of several important 'institutions of settlement' constructed in the wake of the rushes which fundamentally altered patterns of Pākehā settlement in the South Island. ${ }^{25}$ Libraries were markers of settled culture, developed after the frenetic energy of the alluvial goldrush. ${ }^{26}$ Theatre and other live entertainments, by contrast, followed the waves of migration, opening within months of initial rushes, often as small venues attached to hotels. Examining how these institutions developed to cater to the cultural needs of fluctuating populations in the early years of feverish goldrush activity is critical to understanding the extent to which engagement with popular culture more broadly was a 'necessity of life' in haphazard, often short-lived, settlements.

Exploring the scale and content of theatrical entertainment, the precarity of theatre work, and the size and composition of theatre audiences, this study experiments with the utility of quantitative and spatial methodologies to extend the available archival material and enrich a broader historical analysis. Theatre, with its grounding in performance, was ephemeral by nature. The collective experience of the auditorium - the emotions elicited, mechanical effects produced, and behaviour (or misbehaviour) of the audience - did not generate a permanent record and is thus impossible to recapture in full. Moving

\footnotetext{
${ }^{20}$ Sam Hutchinson, Settlers, War, and Empire in the Press, (London: Palgrave Macmillan, 2018).

${ }^{21}$ Lydia Wevers, 'Dickens in New Zealand', Literature Compass, Vol.11, no.5, 2014, p.325.

22 J. E. Traue, 'Reading as a 'Necessity of Life' on the Tuapeka Goldfields in Nineteenth-Century New Zealand', Library History, Vol.23, no.1, 2007, p.48.

${ }^{23}$ Traue, p. 48.

${ }^{24}$ Carolyn Grattan Eichin, From San Francisco Eastward: Victorian Theater in the American West, (Reno: University of Nevada Press, 2020), p.7.

25 Traue, p. 41.

26 ibid, pp.41-48.
} 
beyond repertoire, this study examines theatre players and theatregoers; those who produced theatrical amusements, and those who consumed them. These populations were transient, and the relationships fleeting, connecting people who often had little more in common than coming together on a specified night to see a play.

As such, this thesis is not a history of theatre in isolation but a cultural history which explores the interplay between playhouses and colonial society beyond the stage to analyse theatre as a component of cultural life for those who brought it into being as performers, managers, and patrons. The present study examines culture at two levels, articulated succinctly by Raymond Williams. ${ }^{27}$ The first focuses on theatre's role as a feature of a wider settler or colonial culture which informed and gave meaning to the lived experience of colonial communities. ${ }^{28}$ The second focuses on theatre as a form of culture and a means of engagement with contemporary trends. Here, culture is defined as 'the works and practices' of intellectual and artistic activity. ${ }^{29}$ In examining contemporary culture, this study assesses the spread and uptake of new modes of intellectual and artistic thought and practice - including dramatic works, thematic conventions, and advances in stage design - and how people engaged with those developments.

Focusing on the period c.1850 - 1870, the study examines several garrison and gold town locations to investigate the significance of amateur dramatics and the influence of goldrush wealth on the growth of professional entertainment in New Zealand. Assessing theatrical itinerancy, this study explores the extent to which New Zealand's gold and garrison towns offered touring performers and producers the opportunity to expand into new and lucrative markets thereby connecting New Zealand to wider Anglo networks of cultural and material exchange. Taking a social and cultural historical approach, concentrated analysis examines how the movement of people and theatre culture, working relationships and identities of women and men, and debates over societal morality and respectability shaped the production and success of theatre in this settler colonial context.

Emphasising the centrality of theatre in colonial society, and foregrounding its participants, this thesis analyses how theatres developed and were subsequently used, regulated, and perceived by managers, performers, patrons, and critics. Examining theatre as a place of work allows for analysis of how wider gender dynamics influenced theatre employment, the perception of theatre women and female patrons, and the extent to which social reaction was influenced by British and developing colonial ideals of femininity and proper womanhood. Playhouses were morally ambiguous spaces. Examining the influence of metropolitan spectrums of respectable amusement formulated in London, this study also analyses how contrasting interpretations of theatre as productive of civility or disorder manifest in colonial society. A powerful nexus and marker of metropolitan proximity, theatre served as

\footnotetext{
${ }^{27}$ Raymond Williams, Keywords: A vocabulary of culture and society, (Oxford: Oxford University Press, 1985); Anna Green, Cultural History, (London: Palgrave Macmillan, 2007), p.2.

${ }^{28}$ Williams, p.52.

29 ibid.
} 
a barometer of social civility and connection with the standards, fashions, and trends of Britain, the United States and Australia. Overall, this thesis extends beyond performance to analyse theatre as a vehicle or arena for the spread of Anglo culture, generation of imagined and material connection, performance of gender, and production or degradation of societal and personal respectability in colonial New Zealand.

\section{Theatre, Culture, and Colonisation}

Theatre played a significant role in creating the empire at home in Britain and Ireland. The interaction between empire and popular culture, and the extent to which cultural content was used to bring the concept of empire to the metropolitan context, has been well studied. ${ }^{30}$ Addressing the relationship between empire and the stage more specifically, scholars have assessed the ways in which theatre was utilised to buttress or critique imperial agendas in Victorian Britain. ${ }^{31}$ Marty Gould argues that theatre was 'the privileged vehicle for the transmission of socially reaffirming imperialist discourse,' surpassing the oft-emphasised novel by offering a collective experience which served a 'socially cohesive function. ${ }^{32}$ Theatre reached a wider audience, he argues, because it brought socially and economically diverse groups together in a single space. Through performance, 'the empire itself came to life in London's popular theatrical venues. ${ }^{33}$

Articulating the broader role of culture in colonial societies, Peter Gibbons notes that colonisation was not just a physical process but a cultural one. ${ }^{34}$ Despite expressed intentions to develop new societies, colonisers sought, Gibbons argues, to 'transform the new world...into a simulacrum of the old' through the introduction of their own cultural traditions. ${ }^{35}$ Colonial society was made not just materially with timber, nails, and livestock, but in the contemporary mind through words, imagination, and reinvention. Theatre played into this discourse of construction and fabrication through the interpretations of power, characters, plots, and communities presented on stage. Popular culture enabled people throughout the empire and Anglo-world to keep pace with trends in larger metropoles. Much of

\footnotetext{
${ }^{30}$ John MacKenzie (ed.), Imperialism and Popular Culture, (Manchester: Manchester University Press, 1986); John M. MacKenzie, Popular Imperialism and the Military, (Manchester: Manchester University Press, 1992); Catherine Hall and Sonya Rose (eds.), At Home with the Empire, (Cambridge: Cambridge University Press, 2006).

${ }^{31}$ Nicholas Ryan Appleton, 'Staging an Empire: How Late Victorian Theatre Represents Public Perceptions of the British Empire', MA thesis, University of Maryland, College Park, 2019; Daniel O'Quinn, 'Theatre and Empire', in Jane Moody and Daniel O'Quinn (eds.), The Cambridge Companion to British Theatre, 1730-1830, (Cambridge: Cambridge University Press, 2009), pp.233-246; Jeffery Richards, 'Drury Lane Imperialism', in Peter Yeandle, Katherine Newey, and Jeffery Richards (eds.), Politics, Performance and Popular Culture: Theatre and Society in Nineteenth-Century Britain, (Manchester: Manchester University Press, 2016), pp.174194; Penny Summerfield, 'Patriotism and Empire: Music-Hall Entertainment 1870-1914', in John Mackenzie (ed.), Imperialism and Popular Culture, (Manchester: Manchester University Press, 1986), pp.17-48.

${ }^{32}$ Marty Gould, Nineteenth-Century Theatre and the Imperial Encounter, (New York: Routledge, 2011), p.10.

${ }^{33}$ Gould, p.2.

${ }^{34}$ Peter Gibbons, 'Cultural Colonization and National Identity', NZJH, Vol.36, no.1, 2002, p.14.

35 ibid, p.8.
} 
the theatrical repertoire consumed by New Zealand audiences during the nineteenth century was British or American in origin. In addition, with its reach beyond the written word, theatre extended the impact of print and writing in circulating notions of Britishness and colonial power, thus aiding and abetting the cultural colonisation of New Zealand. ${ }^{36}$

Theatre was used by different groups to both reinforce and challenge colonial authority. Tobias Becker's analysis of traveling companies in colonial India suggests that gaining some control over access to and provision of entertainment enabled colonised peoples to challenge structures which reinforced power imbalance through social division. ${ }^{37}$ Examining Australia, William Dunstone and Helena Grehan argue that the effectiveness of Anglophone theatre 'as an agent of colonisation depended on the mobility of the means of theatre production across space and time. ${ }^{38}$ As actors and companies spread out in search of lucrative performance opportunities, bringing with them repertoire from the imperial metropole, they constructed a set of social relationships which connected audiences and performers throughout the Anglo-world. Theatrical itinerancy and the movement of audiences facilitated the "mediation of cultural and social values between metropoles and colonised places. ${ }^{39}$

Analysis of colonial space forms a crucial part of the present study. Theatre both collapsed and capitalised on distance to connect geographically dispersed audiences through shared experience. Movement of players, patrons, and repertoire characterised the early years of theatre in New Zealand. The members of Shadrach Jones' inaugural theatre company, for example, were not local thespians but professional entertainers recruited from the Victorian goldfield circuit. Following their season in Dunedin, several performed elsewhere in New Zealand or returned to larger population centres such as Melbourne and Sydney. Others set their sights further afield, departing for the bustle and opportunity of theatre districts in San Francisco, New York, and London. This study places New Zealand within that frame of analysis, examining how theatre mapped and connected the wider Anglo-world, and exploring the extent to which theatre shaped imperial dynamics more broadly - constructing the "empire at home' in Britain and contributing to ongoing processes of colonisation in New Zealand.

Several broad studies of Anglophone theatre have been produced. ${ }^{40}$ It has been some time, however, since a comprehensive study of the history of theatre in New Zealand has been undertaken

\footnotetext{
${ }^{36}$ Lydia Wevers, Reading on the Farm, (Wellington: Victoria University Press, 2010), p.19.

${ }^{37}$ Tobias Becker, 'Entertaining the Empire: Theatrical Touring Companies and Amateur Dramatics in Colonial India', The Historical Journal, Vol.57, no.3, 2014, pp.699-725.

${ }^{38}$ William Dunstone and Helena Grehan, 'Chaos' and 'Convergence' on the Western Australian Goldfields: The Politics of Performance in the 1890s', Australasian Drama Studies, no.70, April 2017, p.39.

${ }^{39}$ Dunstone and Grehan, 'Chaos' and 'Convergence', p.39.

${ }^{40}$ Eugene Benson and L. W. Conolly (eds.), The Oxford Companion to Canadian Theatre, (Toronto: Oxford University Press, 1989); Joseph Donohue (ed.), The Cambridge History of British Theatre: Volume 2: 1660 to 1895, (Cambridge: Cambridge University Press, 2004); William Dunlap, A History of the American Theatre from Its Origins to 1832, (Champaign: University of Illinois Press, 2010); Ron Engle and Tice L. Miller (eds.), The American Stage, (Cambridge: Cambridge University Press, 1993); Jane Milling and Peter Thomson (eds.), The Cambridge History of British Theatre: Volume 1: Origins to 1660, (Cambridge: Cambridge University Press, 2004); Kerry Powell (ed.), The Cambridge Companion to Victorian and Edwardian Theatre, (Cambridge:
} 
and the work which has been done leaves room for extension. Maurice Hurst's Music and the Stage in New Zealand (1944) and Peter Downes' Shadows on the Stage (1975) both dealt briefly with theatre during the colonial period and offer some useful summations of its existence from 1840 to $1900 .^{41}$ As largely general surveys, these works provide a chronicle of events and examination of theatre production rather than detailed analysis of theatre in a wider social and cultural space. How people responded to or interacted with the theatre is not examined and the extent to which theatrical entertainment offers an opportunity for interrogation of New Zealand's broader settler culture remains to be assessed.

In 1995 Adrienne Simpson observed that entertainment in nineteenth-century New Zealand had 'generally been overlooked' by historians. ${ }^{42}$ Simpson's observation still holds true. While some more detailed analyses have emerged in recent years, the history of theatre in New Zealand remains largely under studied, and the development of entertainment during those mid-century decades $(1840-1870)$ has been particularly neglected. ${ }^{43}$ Various potted histories note the significance of the period in question, but no detailed study has been attempted. While much of the theatre on offer during the 1840s and 50s was 'ad hoc in nature and amateur in status', by the 1860s a professional industry had begun to develop, and by 1870 attending professional theatre had become a regular part of social life. ${ }^{44}$

The term 'settler culture' is used, consciously, to define the social parameters of the study, but with several caveats. The study examines colonial theatre specifically as it emerged in New Zealand's garrison and gold towns. It is critical to note, however, that the very populations within which theatre thrived were not settled, and this unsettled nature which marked them as potential threats to wider stability. Mobility, albeit at different rates and propelled by different dynamics, characterised the lives of soldiers, diggers, and actors who tracked various paths of empire and exchange. While not settlers, in the sense of intending to reside on the land long term, the 'audiences', 'constituencies of theatregoers', and 'theatre people' at the centre of this analysis were largely non-Māori. Consequentially, this study examines entertainment predominantly, if not exclusively, produced by Pākehā. While Māori performance culture does not form a large part of the present analysis, there is much to be examined there. Settler culture, then, refers to non-Māori culture and its place in Pākehā society, but it is examined here through analysis of the experience and enterprise of itinerant people who were fundamentally mobile and thus did not 'settle' into that culture themselves.

Cambridge University Press, 2004); Don B. Wilmeath and Christopher Bigsby (eds.), The Cambridge History of American Theatre, (Cambridge: Cambridge University Press, 1999).

${ }^{41}$ Maurice Hurst, Music and the Stage in New Zealand: A Century of Entertainment, 1840-1943, (Auckland: Charles Begg, 1944); Peter Downes, Shadows on the Stage: Theatre in New Zealand: The First 70 Years, (Dunedin: J. McIndoe, 1975).

${ }^{42}$ Adrienne Simpson, 'Putting Entertainment on the Map: The New Zealand Touring Circuits in 1874', Australasian Drama Studies, Vol.26, April 1995, p.165.

${ }^{43}$ Lisa Warrington, 'We Are Amused: Theatre Comes to Dunedin, December 1861-April 1862', Australasian Drama Studies, Vol.62, April 2013, pp.41-55; Lisa Warrington, 'Generally Regarded with a Lenient Eye: Amateur Theatre in Dunedin, 1862-1868', Journal of New Zealand Studies, no.15, 2013, pp.101-113.

${ }^{44}$ Simpson, 'Entertainment on the Map', p.154. 
Theatre, 'legitimate drama', and entertainment are also terms used throughout this thesis and should, therefore, be defined at the outset. Entertainment and amusement are the broadest in definition, encompassing a wide array of leisure activities of which theatrical amusements were a subset. Theatre is used broadly too, referring to all live performances analysed in this study as well as the activity surrounding them, both backstage and front. Legitimate drama, a theatrical term, and one which was used by contemporaries, refers to spoken-word dramas and comedies. While widespread, these productions were not the only entertainments on offer during the period. Musical performances, circus, so-called 'illegitimate' genres, and variety shows were all popular, and theatre programmes were regularly diverse. In an environment which demanded novelty, genre boundaries often blurred, and melodrama, song, and trapeze could all appear in a single programme. 'Theatre' denotes a broader category of live performance which encompasses these diverse bills. Music-only performances are not examined. Some attention has been devoted, however, to opera, in part because it is plot-driven and because the response to this brand of 'high culture' offers an insight into the perception of more ordinary dramatic amusement.

The study examines theatre in the context of empire and the wider Anglo-world. ${ }^{45}$ Both constructs provide useful analytical frameworks which contribute to the overall analysis. For the most part, however, the latter is utilised to place New Zealand within the global context. Anglo-world refers to locations where at least some of the population was English-speaking and could, therefore, engage with the same theatrical repertoire. ${ }^{46}$ Spoken word being a significant component of theatrical entertainment, the focus of the study is defined by similar parameters. The choice has been made in part to include analysis of the United States, but also to emphasise the significance of Trans-Tasman and Trans-Pacific connection alongside New Zealand's relationship with metropolitan Britain. As a result, the present study places New Zealand within the wider web of empire, but simultaneously examines the significance of connection to centres of culture in North America and the importance of TransTasman networks of cultural exchange.

Mobility has emerged as a notable theme in recent studies of empire, informing the way scholars construct and analyse historical space. ${ }^{47}$ Tony Ballantyne's conceptualisation of space as webs of imperial connection has proven particularly influential in this regard. ${ }^{48}$ Several scholars have utilised print and performance to analyse the impact of mobility and imperial connection on colonial New Zealand. Analyses of reading and music have highlighted the importance of shared cultural material in

\footnotetext{
${ }^{45}$ James Belich, Replenishing the Earth: The Settler Revolution and the Rise of the Angloworld, (Oxford: Oxford University Press, 2009).

46 ibid, p.58.

${ }^{47}$ Tony Ballantyne, Moving Subjects: Gender, Mobility and Intimacy in an Age of Global Empire, (Urbana: University of Illinois Press, 2009); Tony Ballantyne, 'On Place, Space and Mobility in Nineteenth-Century New Zealand', NZJH, Vol.45, no.1, 2011, pp.50-70; Tony Ballantyne, 'Mobility, Empire, Colonisation', History Australia, Vol.11, no.2, January 2014, pp.7-37.

${ }^{48}$ Tony Ballantyne, Webs of Empire: Locating New Zealand's Colonial Past, (Vancouver: University of British Columbia Press, 2010).
} 
facilitating a sense of connectedness across geographic space, but few studies have included theatre in this discussion and its significance as a form of popular amusement has been subsequently understated. ${ }^{49}$ Producing, performing, and attending the theatre was a collective activity which, alongside entertainment, facilitated connection through shared experience and emotion. These characteristics distinguished theatre from other, more individual, forms of cultural experience. The speed with which theatres were established in permanent and more transient communities across New Zealand also points to their significance as a source of amusement and means of constructing and maintaining a sense of both immediate and more distant community.

Contributing to analyses of mobility in a colonial context, this thesis examines the itinerant movement of actors and managers. Nicole Berkin's analysis of theatre in antebellum America highlighted the impact of touring as an economic and social activity. Itinerancy was, she argues, 'integral to the daily operations of the nineteenth-century theatre business' but it also enhanced public anxiety over respectability and unchecked social mixing..$^{50}$ The itinerancy of theatre people gave them opportunities to work and construct professional identities but simultaneously threatened their already loose reputations. Colonial audiences demanded novelty because limited constituencies of theatregoers, and their pocketbooks, quickly tired of repetition. Regular movement helped theatre people, both men and women, maintain relevance and enabled them to eke out a living as professional entertainers.

\section{Quantifying Colonial Theatre}

Recent work by Lisa Warrington examining the development of amateur dramatics in Dunedin and the early years of professional entertainment in Otago has significantly enhanced understanding of theatre in colonial New Zealand. ${ }^{51}$ Undertaking a broader quantitative analysis, Warrington's Theatre Aotearoa Database (TADB) highlights the utility of systematic analysis as a tool for social and cultural history. ${ }^{52}$ The database is extensive and offers a presently unmatched record of New Zealand theatre, incorporating performances staged in New Zealand, or by New Zealand companies elsewhere, since 1841. Each entry provides the venue and programme of performance alongside notes on genre, actors, playwrights, and country of origin where such information is available. ${ }^{53}$

Preponderance of twentieth-century source material has left the early years, particularly the mid-nineteenth century, under-represented and under-analysed. Of more than 16,000 entries, the TADB

\footnotetext{
${ }^{49}$ Susann Liebich, 'Connected Readers: Reading Practices and Communities across the British Empire, c.18901930', PhD thesis, Victoria University of Wellington, 2012; Jean Clare Gleeson, 'Owner Bound Music: A study of popular sheet music selling and music making in the New Zealand home 1840-1940', PhD thesis, Victoria University of Wellington, 2019.

${ }^{50}$ Nicole Berkin, 'Economies of Touring in American Theatre Culture, 1835 - 1861', PhD thesis, City University of New York, 2015, pp.6, 9.

${ }^{51}$ Warrington, 'We Are Amused', pp.41-55; Warrington, 'Generally Regarded', pp.101-113.

${ }^{52}$ TADB available: http://tadb.otago.ac.nz/Theatre1/Login/Index.php.

${ }^{53}$ Lisa Warrington, 'Archiving New Zealand Theatre - TADB, The Theatre Aotearoa Database', Australasian Drama Studies, no.60, 2012, pp.223-228.
} 
contains just 40 performances staged during the 1840s, with 121 and 401 for the 1850 s and 1860s respectively. These figures significantly underplay both the geographic spread and overall scale of theatre in New Zealand during the period in question. Systematic analysis of newspaper advertisements reveals that there were upwards of 1500 professional productions in Dunedin alone during the 1860s. Meanwhile, on the West Coast, theatres in Greymouth and Hokitika staged more than 300 pieces between 1866 and 1869. Of those productions, just 14 staged in Hokitika are represented. There are no entries for Greymouth. Likewise, military performances in Auckland and New Plymouth are mentioned but the TADB does not provide a full record.

The Performance Database constructed as part of this thesis extends Warrington's work by undertaking a detailed analysis of theatrical performances staged between 1850 and 1870 (see Appendix I). The database allows several fundamental questions to be addressed. First, with several thousand records, it demonstrates the spread and density of theatre during the focus period, significantly enhancing our understanding of the scale of colonial theatrical activity. The Database includes basic details (what was performed, where, and when), alongside playwrights and genre. In addition, several data series provide details beyond the stage including ticket prices, notes on audience reception, and details of when and where plays debuted. The narrower temporal focus allows for a more in-depth assessment of available records, emphasising and better detailing the sheer volume and diversity of nineteenth-century theatrical entertainment hinted at in previous scholarship.

Analysis of newspaper advertisements also reveals the number of professional venues and amateur groups established prior to 1870 , highlighting the significance of theatre as a public social and commercial activity. During the $1840 \mathrm{~s}$ and $1850 \mathrm{~s}$, theatre venues, like the population, were predominantly situated in the North Island. Demonstrating the significance of garrison theatre, Auckland, New Plymouth, Whanganui, and Napier all had specific military venues. Men stationed in Wellington also participated in the local theatre scene, but they did not establish their own theatre. From the 1860 s, the hub of theatrical activity shifted south with venues springing up across the goldfields of Otago and the West Coast (figure 1.1)..$^{54}$

Alongside professional performance, the uptake of amateur dramatics provides evidence of theatre's significance as a component of colonial culture (figures $1.2 \& 1.3$ ). Garrick clubs, modelled on the London original, were exclusively male and offered their members a space to 'tend to the regeneration of the drama. ${ }^{55}$ Amateur societies, first appearing in New Zealand in the 1840s and increasing in popularity and prevalence throughout the following decades, were typically less official in their gender exclusion but the vast majority appealed to prospective 'gentlemen' when canvassing

\footnotetext{
54 Downes, pp.42-43; Adrienne Simpson, Opera's Farthest Frontier: A History of Professional Opera in New Zealand, (Auckland: Reed Publishing, 1996), p.13; Warrington, 'We Are Amused', pp.41-54.

55 James Winston to David Roberts, 19 August 1831, quoted in James Ballantine, The Life of David Roberts, R.A.: Compiled from His Journals and Other Sources, (Edinburgh: Adam and Charles Black, 1866), p.38.
} 
interest. ${ }^{56}$ The existence of these groups highlights the significance of theatre as a social activity, albeit largely for men, even when professional entertainment was inaccessible.
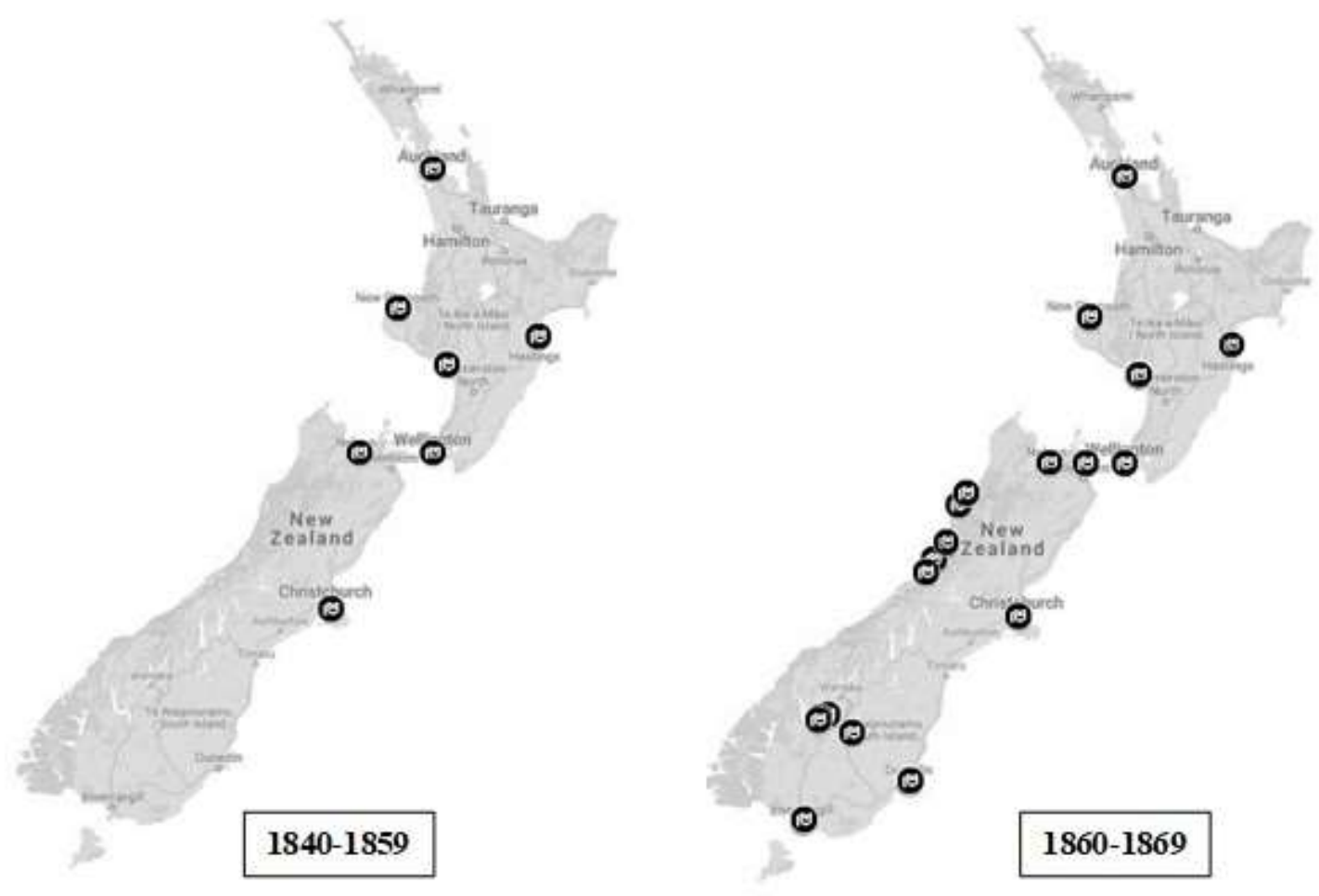

Figure 1.1: Settlements with theatre venues $(1840-1869)$

${ }^{56}$ Lake Wakatip Mail (LWM), 13 June 1863, p.5; Daily Southern Cross (DSC), 12 June 1865, p.1; Lyttelton Times, 26 June 1867, p.3. 


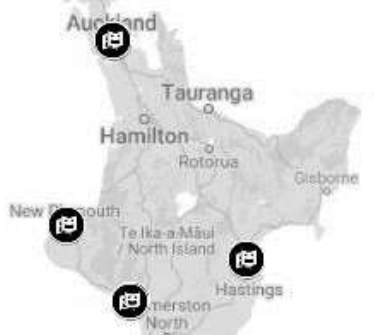

\section{(우 웅}

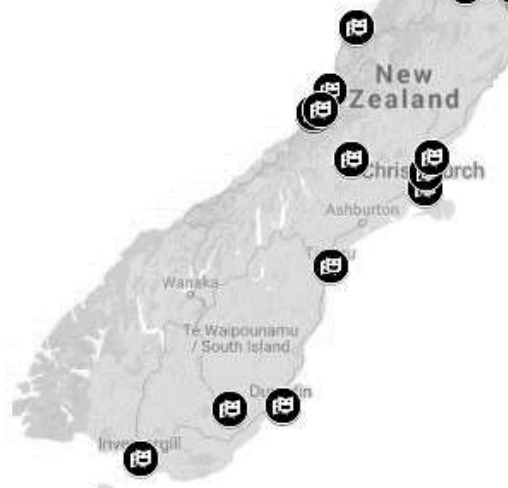

Figure 1.2: Amateur Dramatic Societies 1840 - 1869

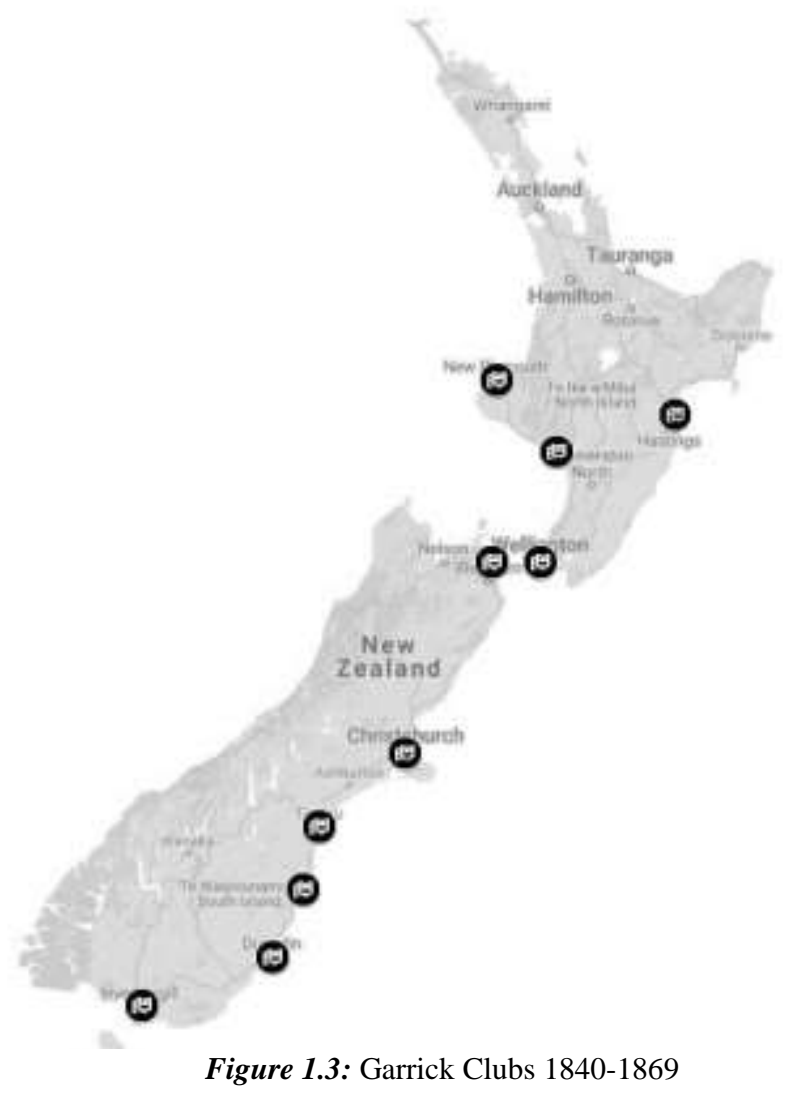




\section{Defining Garrison and Gold Town}

The influence of the Otago goldrush on theatre in New Zealand has been noted in passing by several studies but little scholarship has analysed this effect in greater depth. ${ }^{57}$ The constant ebb and flow of transient wealth marked gold towns as ideal markets for aspiring amateurs or established professional entertainers. Gold towns are defined, for the purpose of this study, as locations where the discovery of gold, and the resulting population boom, most significantly influenced theatre's development. Under this model, Dunedin is included as a 'gold town' where elsewhere it may not be. Prior to 1862, inhabitants noted a 'very plentiful lack' of amusement in the Scottish Presbyterian settlement. ${ }^{58}$ With the discovery of gold, the influx of miners and hangers on dramatically changed the urban landscape, transforming it into a bustling centre of industry and commerce which soon boasted two professional playhouses - the Princess Theatre and the Theatre Royal. Gold transformed Dunedin's theatre scene, and it did the same in Hokitika, Greymouth, and Queenstown.

Garrison theatre is more straightforwardly defined as performances by military amateurs. Auckland and New Plymouth both hosted regiments of the British army during the 1840s and 1850s, and amateur theatres were established at Albert Barracks and Marsland Hill. ${ }^{59}$ Auckland's civilian Theatre Royal was established in 1853, but military performances had provided regular amusement since the late $1840 \mathrm{~s} .{ }^{60}$ While civilian ventures eventually dominated, the $58^{\text {th }}$ regiment contributed significantly to the development of theatre in Auckland. In New Plymouth, the Royal Military Theatre was the settlement's first specific theatre venture, significantly enhancing a civilian amateur scene which was sporadic until $1857 .{ }^{61}$ The $65^{\text {th }}$ regiment occupied the venue until hostilities increased in 1860 and civilian professionals took over when the Royal Princess Theatre was opened on Brougham Street in $1864 .^{62}$ Amateurs of the $65^{\text {th }}$ regiment also performed in Wellington but the city already possessed an established and lively civilian-driven theatre scene.

\section{Tackling Theatrical Ephemerality}

The comparative neglect of theatre in analyses of nineteenth-century settler culture may be attributed in part to several challenges which continue to shape theatre history scholarship more broadly. The most

\footnotetext{
${ }^{57}$ Downes, pp.42-43; Simpson, Opera 's Farthest Frontier, p.13; Warrington, 'We Are Amused', pp.41-55.

${ }^{58} \mathrm{OW}, 11$ January 1862 , p.5.

${ }^{59}$ For analysis of the British garrison in New Zealand see: Adam Davis, 'The Imperial Garrison in New Zealand with particular reference to Auckland', PhD thesis, University of Luton, 2004; Davis, The Furthest Garrison; Macdonald, 'Woolwich to Wellington'; Charlotte Macdonald and Rebecca Lenihan, 'Paper Soldiers: The Life, Death and Reincarnation of Nineteenth-Century Military Files Across the British Empire', Rethinking History, Vol.22, no.3, 2018, pp.375-402; Vincent O’Malley, The New Zealand Wars Ngā Pakanga o Aotearoa, (Wellington: Bridget Williams Books, 2019).

${ }^{60}$ DSC, 23 September 1848, p.1; DSC, 8 November 1853, p.1.

${ }^{61}$ Dr Peter Wilson to Donald McLean, 1 May 1854, New Plymouth, Ref: MS-Papers-0032-0649, ATL; William Halse to Donald McLean, 2 May 1854, New Plymouth, Ref: MS-Papers-0032-0318, ATL.

${ }^{62}$ Taranaki Herald (TH), 5 October 1861, p.2; TH, 22 October 1864, p.2.
} 
salient, occupying a sizeable portion of the methodological historiography, is the barrier posed by the ephemeral nature of theatre itself. ${ }^{63}$ Performance enabled theatre to overcome barriers of literacy and access to written material to become one of few arts which was truly accessible to a wider audience. ${ }^{64}$ As Judith Flanders has illustrated, the fact that stringent censorship laws were imposed more heavily on playwrights than writers as early as 1695 reflects the degree to which performance differentiated engagement with drama and literature. ${ }^{65}$ Declarations that theatre was 'radical' and 'dangerous', something which 'needed to be contained', owed much to its reach beyond the written word. ${ }^{66}$ Recognising theatre not as text but as an event engaged with collectively by its audience significantly expanded the field of analysis and encouraged historians to undertake social and cultural examinations of theatrical culture and its role beyond the stage.

To a significant extent, the theatrical world was demarcated, even dismissed, as fundamentally ephemeral and thereby, while colourful, impossible to analyse. Identifying theatre as a suitable focus for social and cultural historians succeeded, to some degree, in overcoming this barrier. Richard Schoch was among scholars who advanced this argument, seeking to assert theatre's place as a subject worthy of historical analysis. Schoch's argument emphasised the necessity of examining 'what happened off stage, whether in the pit, the press or Parliament,' to appropriately understand theatre's interplay with society at large. ${ }^{67}$ Such thinking opened several possibilities for historians of theatre, including identifying new source material not previously considered relevant. The wide range of sources used in subsequent studies highlights the breadth of theatre's influence beyond the stage. Studies in the last decade have used analysis of theatre to engage with various debates including those surrounding gender, power, and politics. ${ }^{68}$ Scholarship on these topics has dealt with the ephemerality dilemma in different

\footnotetext{
${ }^{63}$ Robert K. Sarlós, 'Performance Reconstruction: The Vital Link Between Past and Future', in Thomas Postlewait and Bruce A. McConachie (eds.), Interpreting the Theatrical Past: Essays in the Historiography of Performance, (Iowa City: University of Iowa Press, 1989), pp.198-229; R.W. Vince, 'Theatre History as an Academic Discipline', in Thomas Postlewait and Bruce A. McConachie (eds.), Interpreting the Theatrical Past: Essays in the Historiography of Performance, (Iowa City: University of Iowa Press, 1989), pp.1-18.

${ }^{64}$ Nina Auerbach, 'Before the Curtain', in Kerry Powell (ed.), The Cambridge Companion to Victorian and Edwardian Theatre, (Cambridge: Cambridge University Press, 2004), p.4.

${ }^{65}$ Judith Flanders, Consuming Passions: Leisure and Pleasure in Victorian Britain, (London: HarperPress, 2006), p.292.

66 ibid.

${ }^{67}$ Richard W. Schoch, 'Theatre and Mid-Victorian Society, 1851-1870', in Joseph Donohue (ed.), The Cambridge History of British Theatre Volume 2: 1660 to 1895, (Cambridge: Cambridge University Press, 2004), p.332.

${ }^{68} \mathrm{Jim}$ Davis and Victor Emeljanow, 'Victorian and Edwardian Audiences', in Kerry Powell (ed.), The Cambridge Companion to Victorian and Edwardian Theatre, (Cambridge: Cambridge University Press, 2004), pp.93-108; Laurence Senelick, 'Signs of the Times: Outdoor Theatrical Advertising in the Nineteenth Century', Nineteenth Century Theatre and Film, Vol.45, no.2, November 2018, pp.173-211; Elizabeth Corsun, 'Boxed-In: Women and Mid-Nineteenth Century Farce', Nineteenth Century Theatre and Film, Vol.41, no.1, May 2014, pp.21-37; Jacky Bratton, The Making of the West End Stage: Marriage, Management and the Mapping of Gender in London, 1830-1870, (Cambridge: Cambridge University Press, 2011); Robin O. Warren, Women on Southern Stages, 1800-1865: Performance, Gender and Identity in a Golden Age of American Theater, (Jefferson: McFarland, 2016); Kerry Powell, 'Gendering Victorian Theatre', in Joseph Donohue (ed.), The Cambridge History of British Theatre Volume 2: 1660 to 1895, (Cambridge: Cambridge University Press, 2004), pp.352-368; Kerry Powell, 'Victorian Theatre: Power and Politics of Gender', in Juliet John (ed.), The
} 
ways. Jim Davis and Victor Emeljanow utilised police reports to examine the theatregoing population of Victorian and Edwardian London. ${ }^{69}$ Laurence Senelick assessed legislation in conjunction with promotional material and street photography to provide a detailed analysis of the development of theatre advertising. ${ }^{70}$ Tracy C. Davis made significant use of personal and business papers in her influential analysis of the economics of theatre management during the long nineteenth century. ${ }^{71}$

Despite clear evidence that there was a lively theatre scene in New Zealand, the amount of material remaining in archival repositories relating to the playhouses themselves is vanishingly small. Similar paucity has been encountered by scholars elsewhere. Analysing touring circuits in antebellumAmerica, Berkin noted that the evidence was both 'uneven and limited. ${ }^{72}$ A similar pattern can be observed in New Zealand where, until the 1870s when more established professional companies came to the fore, the transience of theatrical populations significantly restricted the material trail. ${ }^{73}$ While elsewhere large amounts of printed material which accompanied the theatre industry were preserved, few examples remain in New Zealand archives. Playbills, tickets, programmes, and account books have largely not survived. Those that have, therefore, provide an unmatched, but very partial, view of this vibrant theatrical world. ${ }^{74}$

One place records do survive is in newspapers. ${ }^{75}$ The reciprocal relationship of business and patronage between theatre managers and newspaper proprietors was exhibited in an 1862 dispute between Clarance Holt, then manager of Dunedin's Theatre Royal, and the local press. Following a mildly critical review, Holt saw fit to refuse the editors entry to his establishment. ${ }^{76}$ News of the affront reached readers across the South Island. 'The sympathies of the public are with the insulted editors,' the Southland Times commented, 'and decidedly against the lessee, who, I think, will ere long find out

Oxford Handbook of Victorian Literary Culture, (Oxford: Oxford University Press, 2015), pp.675-685; Jane Woollard, 'The Elasticity of Her Spirits: Actresses and Resilience on the Nineteenth-Century Colonial Stage', Australasian Drama Studies, no.70, 2017, pp.7-34; Bill Dunstone and Helena Grehan, 'Making Maps 'Speak': E-Mapping Performance on Western Australia's Coolgardie Goldfield, 1894-98', Australasian Drama Studies, no.62, April 2013, pp.89-99; Dunstone and Grehan, 'Chaos' and 'Convergence", pp.35-56; Peter Eckersall and Helena Grehan, The Routledge Companion to Theatre and Politics, (Milton: Taylor \& Francis Group, 2019).

${ }^{69}$ Davis and Emeljanow, pp.93-108.

${ }^{70}$ Senelick, pp.173-211.

${ }^{71}$ Tracy Davis, The Economics of the British Stage, (Cambridge: Cambridge University Press, 2000).

${ }^{72}$ Berkin, p.16.

${ }^{73}$ Eichin, p.16.

74 'Second and Third Pages of Military Theatre Programme', 1857, Ref: MS-Papers-2808-02, ATL; 'Handbill for Military Theatre, Albert Barracks', $58^{\text {th }}$ (Rutlandshire) Regiment of Foot - Papers, 19 December 1855, Ref: MS-102-OS-2, Auckland War Memorial Museum (AWMM); 'Military Theatre', 27 August 1855, Ephemera, Ref: EPH-W3-16, AWMM; 'Military Theatre, Marsland Hill', 1857, Archives, Ref: ARC2004-203, Puke Ariki; W. Collins - Taranaki News Office, 'Military Theatre', 19 June 1857, Ephemera, Ref: EPH-W3-14, AWMM; 'Military Theatre - Marsland Hill', 1857, Archives, Ref: ARC2004-203, Puke Ariki; W. Collins - Taranaki News Office, 'Military Theatre, Marsland Hill [Playbill]', 3 July 1857, Archives, Ref: A59.664, Puke Ariki; 'Collection of theatre broadsides relating to Lady Don and her tours of Tasmania, Victoria, New South Wales, New Zealand and the United States of America', 1864-1866, Ref: PA Broadsides 53/1-45, National Library of Australia (NLA).

${ }^{75}$ Eichin, p.17.

${ }^{76}$ Southland Times, 14 December 1862, p.2. 
whether the papers can better do without him, or he without the papers. ${ }^{977}$ Newspapers were crucial features of society in colonial New Zealand. Theatre's reliance on promotion in the press, coupled with traditional reviews and sales benefits for papers from public interest in the activities of the dramatic population, has left newspaper archives with a critical insight into the theatre world.

Alongside newspapers, several other caches of material provide a glimpse of the mechanics of theatre during the focus period. Alongside personal papers which offer a critical first-hand account of theatre management and attendance, useful material has survived from instances where theatre intersected with government. Examination of legislation introduced to regulate theatrical performance and debate surrounding the introduction of those ordinances provides some insight into the official perception and perceived purpose of colonial playhouses. Theatre managers' requirement to adhere to the Licensed Theatres Ordinance (1862) invoked by the Otago Provincial Government is one area worthy of analysis. The fact that the theatre was also a site and source of commercial exchange offers another point of entry. The financial precarity of theatres and their workforce can be assessed through examination of petitions of insolvency filed by theatre practitioners.

Building upon these sources, this study employs several spatial and quantitative methods to test the utility of such tools in extending analysis of archival material. The Performance Database, constructed through detailed examination of several newspaper collections, forms one component of this analysis which attempts to systematically analyse fundamentally qualitative material. Similar methods are used to examine other sources, including data on thefts, assaults, and general disorderly behaviour pulled from the Dunedin Resident Magistrate's Court and the Otago Police Gazette which offer a view into the often-raucous world of the auditorium. These techniques have proven useful for theatre scholarship. Warrington's work has been noted, and further work of this nature has been done in Australia with the Australian Live Performance Database (AusStage). ${ }^{78}$

Spatial analysis has been less widely used but some notable studies provide scope for expansion. Jacky Bratton's analysis of the West End sought to foreground the influence of urban space and mobility on the experience of management, performance, and theatregoing for women in nineteenth-century London. ${ }^{79}$ In Australasia, Dunstone and Grehan have produced two noteworthy pieces of scholarship using data from the AusStage dataset. ${ }^{80}$ Examining performance culture on the Western Australian goldfields, the authors employed social geographer Doreen Massey's interpretation of space as social relations 'stretched out' to analyse how physically isolated gold town theatregoers were 'inalienably and reflexively affiliated with metropolitan centres of theatre production and consumption' throughout colonial Australia and the wider Anglosphere. ${ }^{81}$

\footnotetext{
77 ibid.

${ }^{78}$ AusStage: https://www.ausstage.edu.au/pages/browse.

${ }^{79}$ Bratton, West End Stage.

${ }^{80}$ Dunstone and Grehan, 'Making Maps 'Speak", pp.89-99; Dunstone and Grehan, "Chaos' and 'Convergence", pp.35-56.

${ }^{81}$ Dunstone and Grehan, 'Chaos' and 'Convergence", pp.35-56.
} 
Working across seven locations, situated within a wider framework of migration and cultural transmission, this study deals with space and place in several different ways. At its most fundamental, the concept of space arises with the geographic spread of theatrical activity and the mobility of theatre people across New Zealand. Placing the entertainment of New Zealand garrison and gold towns within the context of the wider sphere of theatrical performance of the Anglo-world offers scope to expand this analysis beyond New Zealand. The material connection of these spaces can be detailed through the movement of three focus populations - mobilised soldiers, footloose gold-seekers, and itinerant thespians. Connecting New Zealand to the California goldfields, British metropoles, and cantonments in colonial India, the movement of people highlights the importance of analysing space and place as interconnected and multifaceted phenomena. Alongside these material connections, an examination of repertoire sheds light on the cultural and imagined spaces and forces which shaped the mid-nineteenth century Anglo-world.

\section{Thesis Structure}

Each chapter takes a different thematic approach to analyse the production, perception, and experience of theatre in colonial New Zealand. Focusing on mobility, chapter one utilises spatial analysis to explore how theatre in New Zealand was shaped by wider networks of cultural and material exchange. Mapping the movement of personnel and repertoire, the analysis enriches existing understanding of theatrical itinerancy and its role in shaping colonial societies. Viewing theatre people as conduits of cultural transmission, the analysis examines the extent to which an extensive Anglo-theatre network enabled New Zealand audiences to participate in broader cultural trends. The chapter draws extensively on the Performance Database and contributes to ongoing discussion of colonial mobility through examination of a transient population largely overlooked in the context of such debates. Drawing on arguments from historians of empire, the analysis foregrounds space as a means of examining theatre's role in connecting New Zealand settler society with the wider Anglo-world. ${ }^{82}$

Chapter two utilises gender to examine theatre as a place of business through close analysis of the people who produced and performed dramatic entertainments in garrison and gold towns. Exploring how theatre operated as a workplace, the analysis draws on debates around colonial femininity and gender norms. ${ }^{83}$ During the mid-nineteenth century, female performers found themselves in an ambiguous position as the increased commodification of theatrical celebrity throughout the Angloworld, coupled with the comparative sparsity of women on the stage, offered them a gendered advantage

\footnotetext{
${ }^{82}$ Belich; Zoë Laidlaw, Colonial Connections, 1815-45: Patronage, the Information Revolution and Colonial Government, (Manchester: Manchester University Press, 2005); Tamson Pietsch, 'Rethinking the British World', Journal of British Studies, Vol.52, no.2, April 2013, pp.441-463.

${ }^{83}$ John Tosh, Manliness and Masculinities in Nineteenth-Century Britain: Essays on Gender, Family and Empire, (New York: Pearson Longman, 2005); Vivien Gardner and Susan Rutherford (eds.), The New Woman and Her Sisters, (Ann Arbor: University of Michigan Press, 1992); Philippa Levine, Gender and Empire, (Oxford: Oxford University Press, 2004).
} 
in the industry but often at the expense of their private reputations. ${ }^{84}$ Analysing several local case studies, this chapter assesses how the place and expected role of women in colonial society was complicated within the theatrical sphere. Building on work by Tracy Davis, Jane Woolard, and Catherine Bishop, analysis of the precarity of theatre business examines the extent to which a stage career was a viable prospect for women in male-dominated communities within a settler colonial context characterised by expectations of female domesticity. ${ }^{85}$

Chapter three takes us to the auditorium, assessing theatre through the lens of colonial respectability to examine how it was perceived and utilised as both civilizing and corrupting. Analysing arguments for or against theatre, this chapter engages with scholarly discussion of Victorian respectability and its implications for colonial society. The chapter examines the extent to which the discourse of respectability influenced the way theatre was regulated - both by law enforcement and public opinion. ${ }^{86}$ Examination of audience behaviour forms a key part of this analysis, which includes discussion of managers' attempts to regulate patrons as a means of promoting the propriety of their venues. Assessing the theatre industry as a place of respectable amusement, but also of reinvention, social mixing, and disorder, the chapter examines the various ways in which theatre promoted or undermined attempts at reinforcing an image of respectable settlement and civility.

\footnotetext{
${ }^{84}$ Amy K. DeFalco Lippert, Consuming Identities: Visual Culture in Nineteenth-Century San Francisco, (Oxford: Oxford University Press, 2018), p.328.

${ }^{85}$ Tracy C. Davis, Actresses as Working Women: Their Social Identity in Victorian Culture, (London: Routledge, 1991); Woollard, pp.7-34; Catherine Bishop, Women Mean Business: Businesswomen in New Zealand, (Dunedin: Otago University Press, 2019).

${ }^{86}$ Goodman.
} 


\title{
Chapter 1
}

\section{Theatre, Mobility, and the Anglo-world}

\begin{abstract}
What is accounted in London good entertainment is adopted in the provinces and colonial theatres... Wherever the English language is spoken, here or at the other side of the world, theatres there will always be, with daily thousands looking to them for amusement. $^{1}$
\end{abstract}

Daily Southern Cross, 1868

In June 1866, theatregoers on the West Coast were treated to performances of two popular dramas. ${ }^{2}$ Dion Boucicault's Janet Pride and The Corsican Brothers, staged at James Bartlett's Prince of Wales Opera House, reached playgoers in Hokitika through an extensive network which connected theatres, performers, and audiences across the Anglo-world. ${ }^{3}$ Both plays had debuted in London. Janet Pride premiered at the Adelphi in 1855 and The Corsican Brothers, which advertisements noted had 'played in London 400 nights', opened at the Princess Theatre on Oxford Street in $1852 .{ }^{4}$ The pieces were brought to life by performers who had honed their craft in Britain, the United States, and Australia, and with effects replicating those from London's principal playhouses. As the audience of Hokitika miners, hotelkeepers, and merchants settled into their seats on those damp evenings in June they took up their place within a web of theatrical commerce which enabled audiences from London to Philadelphia, Melbourne to New York, to enjoy the same piece of theatre rendered with the original 'grand and startling effects. ${ }^{5}$

Constant movement of people, stage techniques, and plays made theatre one of the most widespread and accessible forms of popular culture in the nineteenth century. Connecting audiences, practitioners, and playwrights, the stage offered its participants the ability to engage with a common Anglo repertoire and thereby foster links across geographic space. With advances in transportation and technological innovations, theatre people, their audiences, and the plays they brought to life tracked and constructed paths of cultural and material transmission. Itinerancy was a fundamental part of theatrical life for all performers, not just those who made their living as members of distinct touring groups. As theatre people travelled, they constructed a broader Anglo-theatre network which facilitated the spread

\footnotetext{
${ }^{1}$ DSC, 23 October 1868, p.4.

${ }^{2}$ West Coast Times (WCT), 25 June 1866, p.3.

${ }^{3}$ WCT, 25 June 1866, p.3; WCT, 30 June 1866, p.3.

${ }^{4}$ WCT, 30 June 1866, p.3.

${ }^{5}$ Illustrated London News, 10 February 1855, pp.11-12; Evening Telegraph (Philadelphia), 25 October 1866, p.5.
} 
of theatre culture and connected audiences across the Anglo-world. Adrienne Simpson argues that the consolidation of steamship links to California in the late 1860s brought New Zealand "within the wider entertainment circuit that already encompassed America and Australia. ${ }^{6}$ While transportation developments undoubtedly accelerated the process, the following analysis demonstrates that such improvements simply served to highlight and enhance existing connections and patterns of movement established throughout the 1850s and 1860s.

Alongside theatre workers and performers, mobile consumers such as soldiers and gold-seekers also facilitated the spread of theatre culture throughout New Zealand. All three groups lived a transient existence, but the nature of their movement was fundamentally different. Soldiers moved purposefully, but subject to military command. As part of a wider pattern of global mobility operating in the name of empire, the movement of regiments constructed a web of imperial control which, beginning in Britain, encompassed parts of India, North America, Asia, Africa, the Caribbean, and Australasia. The movement of the gold-seekers converging on Otago and the West Coast, by comparison, was individual, autonomous and fortune-seeking, tracking paths of migration which connected mineral-rich mountains and creek beds in California to similar environments in Victoria, British Columbia, and New Zealand. Actors and managers, driven by their search for employment, bridged the disconnect between colonial garrison camps, haphazard gold towns, and centres of fashion, population, and industry.

Within New Zealand, the migration of theatre people was heavily influenced by wider patterns of movement, most notably the goldrush migrations during the 1860s. Gold discoveries, which precipitated a population boom in Otago and Westland, saw Dunedin expand rapidly and small settlements and cities of calico tents at Queenstown, Hokitika, Greymouth, and Westport swiftly establish themselves as permanent supply towns. Less than a year after Gabriel Read's discovery of gold at Tuapeka in 1861 instigated the first major rush in Otago, Dunedin boasted two permanent theatres. On the West Coast, Hokitika became a prominent site of theatrical entertainment thanks in large part to enthusiastic actor-manager James Bartlett's 1400-seat opera house which opened in 1866, a year into the first major rush in that area.

To analyse the early years of theatre in New Zealand, the stage must be placed within wider networks of commerce, cultural exchange, and mobility. The following assesses the extent to which movement of performers and repertoire facilitated the development of a vast Anglo-theatre network. In the United States, Nicole Berkin argues, theatre acted 'as a channel for the circulation of ideas, people, and objects. ${ }^{97}$ The movement of theatre people in New Zealand emphasised the cultural impact of wider patterns of mobility, linking the colony to the Anglo-world through direct association with the playhouses of Britain, the United States, and Australia. Steamship routes and the expansion of passenger

\footnotetext{
${ }^{6}$ Simpson, 'Entertainment on the Map', p.154.

${ }^{7}$ Berkin, p.7.
} 
railway played a critical role in extending access to theatrical entertainment, encouraging performers and managers to 'both accommodate and generate new entertainment markets."

Tamson Pietsch's rethinking of imperial relations complicated by interpretations of space as variously material, absolute, and imagined can be used fruitfully to examine how theatre, and patterns of trade and movement which influenced its growth, connected geographically dispersed locations. ${ }^{9} \mathrm{On}$ a material level, the movement of goods and people played a critical role in shaping the accessibility and content of theatre culture. Analysing access to repertoire, players, and stagecraft, assessment of material space illustrates the cultural significance of New Zealand's place within broader patterns of commercial exchange and migration. Additionally, examination of the extent to which theatre constructed an abstract network through shared experience, provides scope to assess how performance and consumption of common repertoire condensed the imagined space of the Anglo-world.

An assessment of the mobility of theatre people, and spread of repertoire, is critical to understanding theatre as a component of New Zealand settler culture during the mid-nineteenth century. To assess both elements, the following chapter is divided into two sections. The first analyses theatrical itinerancy through the movement of the people at the heart of the early colonial theatre scene. Examination of the way actors were promoted opens discussion to assess how the movement of theatre people aided in processes of cultural transmission and the construction of a vast Anglo-theatre network. Taking a sample of eight performers, spatial and network analyses interrogate the complex and intensely interwoven nature of Anglophone theatre during the mid-nineteenth century (see Appendix II). In addition, an assessment of touring patterns within New Zealand, tracing two professional companies, explores the economics and ease of touring in this colonial context.

The second section analyses theatre repertoire to explore how what was staged in New Zealand theatres was informed by various imperial and Anglo networks. Incorporating the stage into wider analyses of popular culture, this section explores the contemporary popularity of theatrical entertainment, and its influence on settler audiences' sense of connectedness with the fashions and tastes of the wider Anglo-world. ${ }^{10}$ Tracing the performance of five plays, the analysis demonstrates the extent to which New Zealand's place within a broader theatre network shaped the repertoire on offer in colonial playhouses. In addition, some discussion addresses the extent to which analysis of networks of personnel and repertoire can be used to assess how theatre, and culture more broadly, constituted relations of empire and aided processes of colonisation.

\footnotetext{
${ }^{8}$ Berkin, p.8.

${ }^{9}$ Pietsch, pp.441-463.

${ }^{10}$ Gleeson; Liebich.
} 


\section{Space and Anglo-theatre Networks}

Seeking to decentralise the nation and challenge models which place undue emphasis on the British metropole, Tony Ballantyne's Webs of Empire presents a strikingly interwoven interpretation of imperial space. ${ }^{11}$ The movement of goods, people, and ideas was, Ballantyne argues, not unilateral metropole to periphery - nor bidirectional. Rather, it constituted a complex web of relationships linking metropole and colony enmeshed with trans-colonial networks operating independent from metropolitan action. Imperial connections were dynamic, constantly made and remade, as they linked "points in space' to create 'strong threads of interdependence.' ${ }^{12}$ Connected through 'practices and sites' where knowledge was 'accessed, made, and shared', colonial centres of commerce, industry, and culture played a crucial role, he argues, in shaping settler communities. ${ }^{13}$

Expanding trans-colonial connections highlighted in Ballantyne's model, Zoë Laidlaw argues that imperial space is best analysed as a series of networks which capture 'the complex and irregular systems of connection' joining people and places across the empire. ${ }^{14}$ Networks varied, she argues, in complexity and scale, but were characterised by the manner in which they 'encouraged the transmission of ideas, and experience. ${ }^{15}$ Laidlaw argues that individual connection through shared experience, vocation, or more intangible endeavour played a crucial role in shaping processes of colonial governance during the nineteenth century. ${ }^{16}$ She defines the significance of networks by the extent to which they succeeded in transmitting 'information, position and power' to 'high-profile individuals in Britain. ${ }^{17}$ Testing the utility of this model to examine other modes of influence opens space to assess the networks of cultural transmission which shaped the construction and experience of empire and the wider Anglo-world.

Playhouses throughout Britain's colonies served as markers of metropolitan influence drawing connections to the West End and symbols of imperial power. Materially, plays and performers linked New Zealand audiences with closer touring circuits in Victoria and New South Wales, as well as celebrated centres of entertainment in the United States. Tobias Becker argues that architecture and venue names illustrated the extent to which theatre fostered connection not just within colonial society but between colony and imperial metropole. ${ }^{18}$ Theatre in New Zealand thus constructed two different forms of association; a largely intangible and imagined connection with Britain and the West End, and a more direct association with playhouses in Australia and North America.

\footnotetext{
${ }^{11}$ Ballantyne, Webs of Empire.

12 ibid, p.295.

13 ibid, p.247.

${ }^{14}$ Laidlaw, p.14.

15 ibid.

16 ibid, pp.13-38.

17 ibid, p. 17.

${ }^{18}$ Becker, p. 721.
} 
Theatres Royal, drawing parallels with the royal patent theatres in Covent Garden and Drury Lane, proliferated across the empire. In the colonies, the regal title regularly denoted nothing more substantial than a hotel backroom. Venues adopting the regal moniker sprang up in settlements throughout New Zealand, New South Wales, and Victoria connecting these settler societies with British populations in Calcutta, Lahore, Firozpur, and Maharashtra. Playhouses invoking the Prince of Wales or Duke of Edinburgh, were also popular, connecting geographically dispersed colonial localities as far afield as Hokitika, Nelson, Sydney, Gulgong, and Simla. Drawing parallels with London's elite theatre district, Haymarket, Lyceum, and Adelphi theatres also appeared throughout the wider colonial world.

Social geographer Doreen Massey's analysis Space, Place and Gender conceives of space not as an 'absolute independent dimension', but a construct shaped by human perception and interaction. ${ }^{19}$ Utilising this interpretation in their analysis of performance culture on the Western Australian goldfields, William Dunstone and Helena Grehan highlight the extent to which theatre connected playgoing populations in the gold towns with contemporaries throughout Australia and further afield. ${ }^{20}$ Dunstone and Grehan thus interpret theatre venues as salient sites of cultural connection which, regardless of scale, constituted 'dislocated fields of social relations "stretched out" over time and space. ${ }^{21}$ As such, they argue, theatre drew a salient connection between past and present, as well as connecting contemporary audiences through shared repertoire and technological innovation.

In a similar vein, Berkin argues that theatres provided channels 'for the circulation of ideas, people, and objects. ${ }^{22}$ Increasing the accessibility of professional entertainment for audiences in smaller settlements, touring also enhanced the status of actors who used their extensive mobility to accrue 'symbolic capital' and construct widespread professional reputations. ${ }^{23}$ Providing a close analysis of the development of celebrity in the nineteenth century, Amy Lippert highlights the extent to which theatrical entertainment connected urban centres across the globe through the commodification and exchange of 'theatrical stars. ${ }^{24}$ Theatrical mobility was facilitated, she argues, by connection with established networks of cultural and commercial exchange defined and characterised by the spread of print, imagery, people, and capital..$^{25}$

Theatre networks, forged by the movement of people, assisted the spread of traditional and popular repertoire. In addition, much like networks identified by Laidlaw, they afforded their members certain privileges. Theatre work was irregular and precarious. Thus, fostering a reputation through both ability and connection was critical for the survival of itinerant performers. Personal relationships were useful for securing contracts and these patterns of individual connection linked playhouses and wider

\footnotetext{
${ }^{19}$ Doreen Massey, Space, Place and Gender, (Minneapolis: University of Minnesota Press, 1994).

${ }^{20}$ Dunstone and Grehan, 'Chaos' and 'Convergence", pp.35-56; Massey.

${ }^{21}$ ibid, p.39.

${ }^{22}$ Berkin, pp.7, 9.

${ }^{23}$ ibid.

${ }^{24}$ Lippert, p.315.

${ }^{25}$ ibid, p.316.
} 
population centres within a web of theatrical commerce. Strong links with the Victorian goldfield circuit played a crucial role in shaping the theatre scene in Dunedin. Here, enterprising managers like Clarance Holt and Tom and Sandford Fawcett capitalised on connections fostered during seasons in Bendigo, Ballarat, and Melbourne to secure engagements with big names touring Victoria. The steamship route between Melbourne and Dunedin was the lifeblood of Otago theatre during its infancy, as managers and performers travelled back and forth across the Tasman.

Empire offered colourful scenes and plots which producers of Victorian popular culture quickly capitalised on. The dramatization of colonial events aided in the construction of imperial identities throughout settler communities and metropolitan Britain. Alongside novels and songs, theatre, Gould has noted, brought the empire to life for paying patrons in all its emotion and spectacle.$^{26}$ Productions depicting settings throughout the empire were rendered for New Zealand audiences. Such plays brought patrons face to face with both exotic and familiar inhabitants of other British colonies. Charles Reade's dramatic adaptation of colonial Australia in Never Too Late to Mend, for example, was staged in Dunedin in 1863 and brought audiences face to face with bushrangers, gold-diggers, and Aboriginal Australians. ${ }^{27}$ Elsewhere, Charles Dance's The Bengal Tiger, performed by military amateurs at Marsland Hill in May 1858, painted a sympathetic, though overly simplified, portrait of British domestic life in colonial India. ${ }^{28}$

The Indian Rebellion of 1857 inspired a plethora of cultural works that brought the tensions and violence of colonial rule to drawing rooms, music halls, and playhouses throughout the Angloworld. ${ }^{29}$ Dion Boucicault's drama Jessie Brown or The Relief of Lucknow, and its cast of imperial soldiers and Indian 'rebels', debuted at Wallack's Theater in New York in $1858 .{ }^{30}$ Boucicault's depiction, centralising the fictionalised experience of two Scottish women caught up in the siege of Lucknow, attempted to culturally legitimise the violence of British imperialism and reinforce derogatory interpretations of the Indian struggle for independence. Various stage techniques enabled theatre to bring the events to life in vibrant colour and vivid detail. Culminating in a chaotic scene of 'shouts and musketry and cannonade' with a 'back scene...covered with a red glow; explosions, as from mines' all accompanied by bagpipes, Boucicault's representation enthralled audiences throughout the Anglo-world. ${ }^{31}$

Dunedin patrons were invited to 'come and see the storming of Lucknow' when Jessie Brown debuted at the Princess Theatre in October 1862 complete with 'the greatest scenic effects ever

\footnotetext{
${ }^{26}$ Gould, p.2.

27 ibid, p.9; ODT, 28 September 1863, p.4.

${ }^{28}$ Gould, p.116; $T H, 1$ May 1858, p.2.

${ }^{29}$ Jill Bender, The 1857 Indian Uprising and the British Empire, (Cambridge: Cambridge University Press, 2016); Kim A. Wagner, "'Treading Upon Fires": The 'Mutiny'-Motif and Colonial Anxieties in British India', Past \& Present, Vol.218, no.218, 2013, pp.159-197.

${ }^{30}$ Dion Boucicault, Jessie Brown or The Relief of Lucknow, (New York: Samuel French, 1858).

${ }^{31}$ Boucicault, Jessie Brown, p.31.
} 
produced' in New Zealand. ${ }^{32}$ The cast itself was dramatic in scale. A performance in Christchurch in 1864 advertised for 50 supernumeraries. ${ }^{33}$ Presenting re-enactments of imperial events, theatre invited audiences to participate through the action they witnessed on stage. Foregrounding the experience of relatable characters, Boucicault's production struck a chord with colonists in Dunedin, inspiring sympathetic outrage and solidarity with the Anglo, or rather Scottish, community in India. Reviews demonstrate the broad social reach of the stage as a conveyor of imperial discourse which presented the trials and tribulations of fellow colonists in other settings, with which many were already familiar through news and print, to the delight of audiences in both pit and dress circle. ${ }^{34}$ Reporting on the Dunedin performances, the Otago Daily Times noted:

The scenic effects were well arranged, and gave a very good idea of the beleaguered fort. There was a proper quantity of firing, and any quantity of "villainous saltpetre" was consumed to the intense delight of the pit...There was a very good house, the pit and stalls were crowded, and the dress circle and boxes respectably filled. ${ }^{35}$

Performances to raise money for charitable causes also often explicitly emphasised broader relations of empire. In garrison settings, widows and orphans of soldiers of the regiment were the most common recipients of such relief. ${ }^{36}$ On occasion, however, benefits were staged for more abstract or distant beneficiaries. The extent to which these performances played into a discourse of imperial patriotism provides an insight into how theatre networks contributed to ongoing processes of colonisation. Garrison performances at Marsland Hill held in aid of the Indian Relief Fund, for example, highlighted New Plymouth's place within a broader colonising agenda. ${ }^{37}$ Two years later, as war raged in Taranaki, civilian performers in Wellington used theatre to raise funds for Pākehā settlers. ${ }^{38}$ Becker has highlighted the extent to which reclamation of theatre space and content challenged colonial structures in India. ${ }^{39}$ While some contemporary work sought to challenge the assumptions and operation of colonial power, charity performances were intended to inspire sympathy and support for British populations, and thus did not offer any critique of colonial processes more broadly. Theatre which drew attention to imperial events and struggles offered colonists a chance to interact with the empire at large.

\section{Theatrical Itinerancy}

Several smaller webs came together to construct broad networks which shaped the development of theatre in New Zealand. British influence played a part in informing available repertoire and

\footnotetext{
${ }^{32}$ ODT, 4 October 1862, p.3; ODT, 6 October 1862, p.3.

${ }^{33}$ Press (Christchurch), 11 January 1864, p.1.

${ }^{34}$ Hutchinson.

${ }^{35}$ ODT, 7 October 1862, p.4.

${ }^{36}$ Arthur Frederick Pickard, 'Diary, Private A F Pickard', 1860-1863, Ref: 76173, MTG Hawke’s Bay.

37 TH, 1 May 1858, p.2.

${ }^{38}$ Wellington Independent, 7 August 1860, p.2.

${ }^{39}$ Becker, pp.699-725.
} 
contributing to the pool of performers, but theatre networks ultimately transcended imperial boundaries. New Zealand's early theatres relied more heavily on intercolonial association with playhouses in New South Wales and Victoria than on direct connection with Britain. In addition, following broader patterns of migration, the cultural world of the United States played a significant role in shaping the discourse, content, and production of New Zealand's theatre repertoire. Britishness, or Englishness more specifically, continued to be viewed as 'the badge of theatrical respectability' but on the ground, in the auditorium, association with the imperial metropole did not have the only, nor the most significant, impact on theatre in colonial New Zealand. ${ }^{40}$

Technicians, players, and managers linked playhouses and audiences through itinerant movement which tracked paths of culture and commerce throughout the empire and wider Anglo-world. Theatre people, acting as conduits of cultural transmission, facilitated the spread of repertoire and technological innovation. The flow of the network ensured that plays and various developments in stagecraft reached New Zealand with remarkable speed. The increase in use of magnesium lamps in American theatres in place of limelight, for example, was noted by the Otago Daily Times in early April $1866 .{ }^{41}$ Less than a month later, Princess Theatre manager Stuart O’Brien announced that he would introduce a new 'artificial light...of lasting and unequalled brilliancy' for the upcoming season, and Christchurch-based scenic artist J.S. Willis secured the loan of a magnesium lamp for $£ 2 .{ }^{42}$

Ownership of rights to stage particular plays and actor expertise were also influential. James Bartlett owned the Australasian rights to Tom Taylor's The Contested Election, and Joey Gougenheim, who was very familiar with Taylor's work, reprised the role of Nell Gwynne in Court and Stage for audiences in Sacramento, San Francisco, Melbourne, Hobart, Dunedin, and Hokitika. ${ }^{43}$ Likewise, Clarance Holt offered Dunedin audiences his 'world-famed' Belphegor, which he had played 'upwards of 500 nights throughout England, America, and the Australian Colonies. ${ }^{44}$ Backstage, machinist George Cooper recreated spectacular effects for The Sea of Ice at Bartlett's Prince of Wales Opera House which he had first produced during the piece's debut season at the Adelphi in London. ${ }^{45}$

With metropolitan fashions shaping theatrical taste and style for settler communities, the transmission of repertoire played a part, as Gibbons argues, in processes seeking to transform the new world into a "simulacrum of the old. ${ }^{46}$ However, the significant influence of theatres and playwrights in Boston, New York, and San Francisco ensured that the material consumed in New Zealand was not

\footnotetext{
${ }^{40}$ Christopher Bigsby and Don B. Wilmeath, 'Introduction', in Don B. Wilmeath (ed.), The Cambridge History of American Theatre, (Cambridge: Cambridge University Press, 1999), p.8.

${ }^{41} O D T, 4$ April 1866, p.4.

${ }^{42}$ ODT, 27 April 1866, p.4; 'WILLIS, John Stanley - Dunedin - Scenic Artist', Schedule B, 1866, Dunedin Debtors Petition Files, Ref: R19952978, Dunedin, ANZ.

${ }^{43}$ Daily Alta (San Francisco (SF)), 25 August 1855, p.2; Sacramento Daily Union, 31 December 1855, p.2; Argus (Melbourne), 21 March 1862, p.4; Mercury (Hobart), 14 April 1862, p.2; ODT, 22 November 1864, p.1; WCT, 7 November 1866, p.3.

${ }^{44}$ ODT, 28 November 1863, p.6; ODT, 27 June 1864, p.6.

${ }^{45}$ WCT, 30 June 1866, p.3.

${ }^{46}$ Gibbons, p.8.
} 
exclusively product of the British metropole. While theatre networks aided in spreading imperial influence, they also linked New Zealand and the United States and thus played a critical role in constructing both a tangible and imagined connection between New Zealand settler society and the wider Anglo-world.

Advertising played a crucial role in illustrating broader networks of theatrical mobility. Capturing a sense of movement and transient connection, whilst simultaneously positioning local audiences within a broader theatre network, players fulfilling short-term engagements in New Zealand were regularly promoted as performing 'en route' to, or imminently departing for, theatre markets further afield. In April 1866, Lady Emily Don performed her final shows at the Princess Theatre 'previous to her departure for Callao' followed, two months later, by popular musicians $\mathrm{Mr}$ and Mrs Joseph Heine who made a farewell appearance 'en route via San Francisco to the American States. ${ }^{47}$ In Hokitika, on countless occasions, James Bartlett emphasised the impending departure for Sydney or Melbourne of star engagements in the hopes of drumming up interest enough to fill his auditorium for a few more nights.

In July 1863, Clarance Holt and Joseph Wolfe - managing Dunedin's Princess Theatre announced engagements with a host of well-established colonial performers (figure 2.1). ${ }^{48}$ The theatrical connection between Otago and Victoria was displayed. Four performers - Annie Merton, Francis Stuart O'Brien, and Messrs Richardson and Newton - were all veterans of the Victorian theatre circuit. Bendigo, Ballarat, and Melbourne were Victoria's largest theatre centres, and performers regularly visited New Zealand after a stint on the Victorian goldfields. Holt and Wolfe's association with Victoria, where they had both enjoyed success themselves, allowed them to negotiate contracts with other performers. It is also worth noting the promoted engagements of Miss Aitken and Mrs Hatta [Hetta] Fleming, both of whom were marketed using their connection to Britain. Fleming, of the Theatre Royal Haymarket, drew instant connection to London's elite theatre district while Aitken, a 'celebrated Scotch Tragedienne and Elocutionist', had performed at 'the principal Edinburgh, Glasgow, and London Theatres. ${ }^{49}$

\footnotetext{
${ }^{47} O D T, 26$ April 1866, p.1; ODT, 7 July 1866, p.1.

${ }^{48}$ ODT, 11 July 1863, p.3.

${ }^{49}$ ibid.
} 
ROYAL PRINCESS' THEATRE. Under the Management of Messrs Holt and Wolfe.

GRAND OPENING NIGHT OP THE

NEW DRAMATIC COMPANY.

MONDAY NXXT, JULY 13TH,

The following Powerful Host of Talent will appear :-

M I S S I T K R $N$,

The celebrated Scotch Tragedienne and Flocutionist,

from the principal Edinburgh, Glasgow, and Londun Theatres.

MRS HATTA FLEMING

(From the Theatre Royal Haymarket, London).

MISS ANNIE MERTON

(From the Theatre Royal, Ballarat.)

MR R. STUART O'BRIEN

(From the Theatre Royal, Melbourne).

MR RICHARDSON

(Brom the Lyceun Theatre, Bendigo).

MR NEWTON

(Rrom the Theatre Royal, Ballarat).

With

MR and MRS CLARANCE HOLT,

J. M. WOLPE.

W. Ryan, R. B. Dale, John Hall, W. D. Shiels

P. Howe, J. Mordaunt,

Miss Montrose, Mess Ellen Holt, LITTLE MAY,

And a numerous force of Auxiliaries, engaged for the New Season.

Figure 2.1: The company engaged by Clarance Holt and Joseph Wolfe in July 1863 highlights the interconnections generated by theatrical itinerancy, and the prestige of particular venues. All visiting stars were advertised as having performed in other locations.

Source: $O D T, 11$ July 1863, p.3. 
As consumers of theatrical culture, theatregoers moving throughout the Anglo-theatre network aided in the construction of trans-continental professional reputations. Such movement made it possible for the likes of comic actress Joey Gougenheim to be greeted as 'a some-time absent favourite' when she first appeared in New Zealand in $1864 .{ }^{50}$ Evidently, the Otago Daily Times reported, the inaugural performance of the actress who had never set foot in Dunedin was not so much a debut as 'a reappearance before a large number of old friends in a new place. ${ }^{51}$ Broader patterns of fortune-seekers moving from California to Australasia laid the foundations of a trans-Pacific network through which goods, capital, information, and people travelled throughout the second half of the nineteenth century. Taking advantage of the demand for entertainment in goldrush settlements, theatre people made extensive use of these new transport and trade routes to foster their own fame and wealth. The extent to which goldrush migration facilitated the movement of not just players but playgoers was significant.

Colonial playgoers retained a remarkable interest in the careers and lives of stage performers. Newspapers both capitalised on and fostered this curiosity, reporting extensively on the ongoing tours of former local favourites. An 1873 correspondence, republished throughout the colony, detailed the movement of several players who had previously performed in Christchurch. Believing information on 'the movements of several members of the theatrical profession' may be of interest, the press noted former favourites now playing or managing variously in Sydney, Bathurst, Adelaide, Brisbane, Calcutta, and China. ${ }^{52}$ In 1876, demonstrating the longevity of the relationship between actor and audience, reports and extended obituaries appeared throughout Otago, Canterbury, and Westland when burlesque star Julia Mathews - who had performed in New Zealand during the 1860s - died in St Louis. ${ }^{53}$ Despite not returning to New Zealand following her departure in 1866, the social relations Mathews had fostered with the Dunedin public saw her death generate 'a feeling of deep regret' among former patrons. ${ }^{54}$

Touring was essential for nineteenth-century theatre people. In Britain, this itinerant mobility offered actors the chance to accrue both experience and capital performing for provincial audiences before venturing to the London stage. ${ }^{55}$ In colonial societies, touring routes increased access to professional entertainment outside urban areas, but the profit-driven patterns also constructed divisions which impacted large swathes of the population. Seeking profit and larger audiences, professional

\footnotetext{
${ }^{50}$ ODT, 22 November 1864, p.4.

51 ibid.

${ }^{52}$ Evening Star (Dunedin), 23 June 1873, p.2.

${ }^{53}$ Cromwell Argus, 4 July 1876, p.5; Dunstan Times, 1 September 1876, p.3; Evening Star (Dunedin), 19 August 1876, p.3; Grey River Argus (GRA), 1 September 1876, p.2; Lake County Press, 5 July 1876, p.2; Timaru Herald, 7 July 1876, p.3; Tuapeka Times, 23 August 1876, p.4; WCT, 2 September 1876, p.3; Westport Times, 18 July 1876, p.2.

${ }^{54}$ Timaru Herald, 7 July 1876, p.3.

${ }^{55}$ Kathleen Barker, 'A Provincial Tragedian Abroad', Theatre Research International, Vol.11, no.1, 1986, p.31.
} 
entertainers prioritised bigger or richer towns and cities over smaller communities which were often harder to reach and did not promise a healthy financial return. ${ }^{56}$

The following discussion analyses the itinerancy of eight performers to assess the structure and geographic spread of theatrical networks which shaped the entertainment in New Zealand's colonial playhouses. Each performer has been traced using newspaper advertisements located in digital archives - Papers Past (New Zealand), Trove (Australia), Chronicling America (United States), the California Digital Newspaper Collection, and the British Newspaper Archive (Britain and India). ${ }^{57}$ The eight performers - actor-managers George, Tom, and Sandford Fawcett, comic actresses Joey Gougenheim, Dolly Green, and Marian Dunn, burlesque star Julia Mathews, and tragedienne Rosa Cooper - all performed at the Princess Theatre in Dunedin during the 1860s. This playhouse serves as a locus of performance. From there analysis of touring patterns and general mobility of each performer reveals the scale and complexity of the nineteenth-century theatre network which connected New Zealand to the empire and wider Anglo-world.

The sample of performers connected Dunedin's theatregoing public to audiences in more than forty towns and cities (figure 2.2). More detailed analysis reveals connections to sixty-five individual venues across New Zealand, Australia, Britain, the United States, and India. These connections have been visualised using a network map (figure 2.3), with venues represented by nodes and theatre people serving as links. Nodes are colour-coded by broader location. To better examine the impact of the Victorian gold town circuit, and Sydney and Melbourne as colonial metropoles, Australia is broken down by colony to allow connections to Victoria, New South Wales, Queensland, and Tasmania to be examined independently. ${ }^{58}$ As performers moved, they constructed a version of space and place which enabled audiences to view themselves as part of a wider network of cultural consumers. Through shared repertoire and personnel, theatre collapsed distance, connecting audiences at the Princess Theatre in Dunedin with those attending the Lyceum Theatre in Ballarat, Maguire's Opera House in San Francisco, the Prince of Wales in Simla, and the Haymarket on London's West End.

\footnotetext{
${ }^{56}$ Michael R. Booth, 'Gold Rush Theater: The Theatre Royal, Barkerville, British Columbia', The Pacific Northwest Quarterly, Vol.51, no.3, 1960, p.97; Douglas McDermott, 'Touring Patterns on California's Theatrical Frontier, 1849-1859', Theatre Survey, Vol.15, no.1, 1974, pp.18-28; Simpson, 'Entertainment on the Map', pp.153-76.

${ }^{57}$ Papers Past: https://paperspast.natlib.govt.nz; Trove: https://trove.nla.gov.au; Chronicling America: https://chroniclingamerica.loc.gov; CDNC: https://cdnc.ucr.edu; BNA: https://britishnewspaperarchive.co.uk.

${ }^{58}$ Full network map: www.entertainingprospects.weebly.com/networks.html.
} 


\section{Network Map: Towns and Cities}

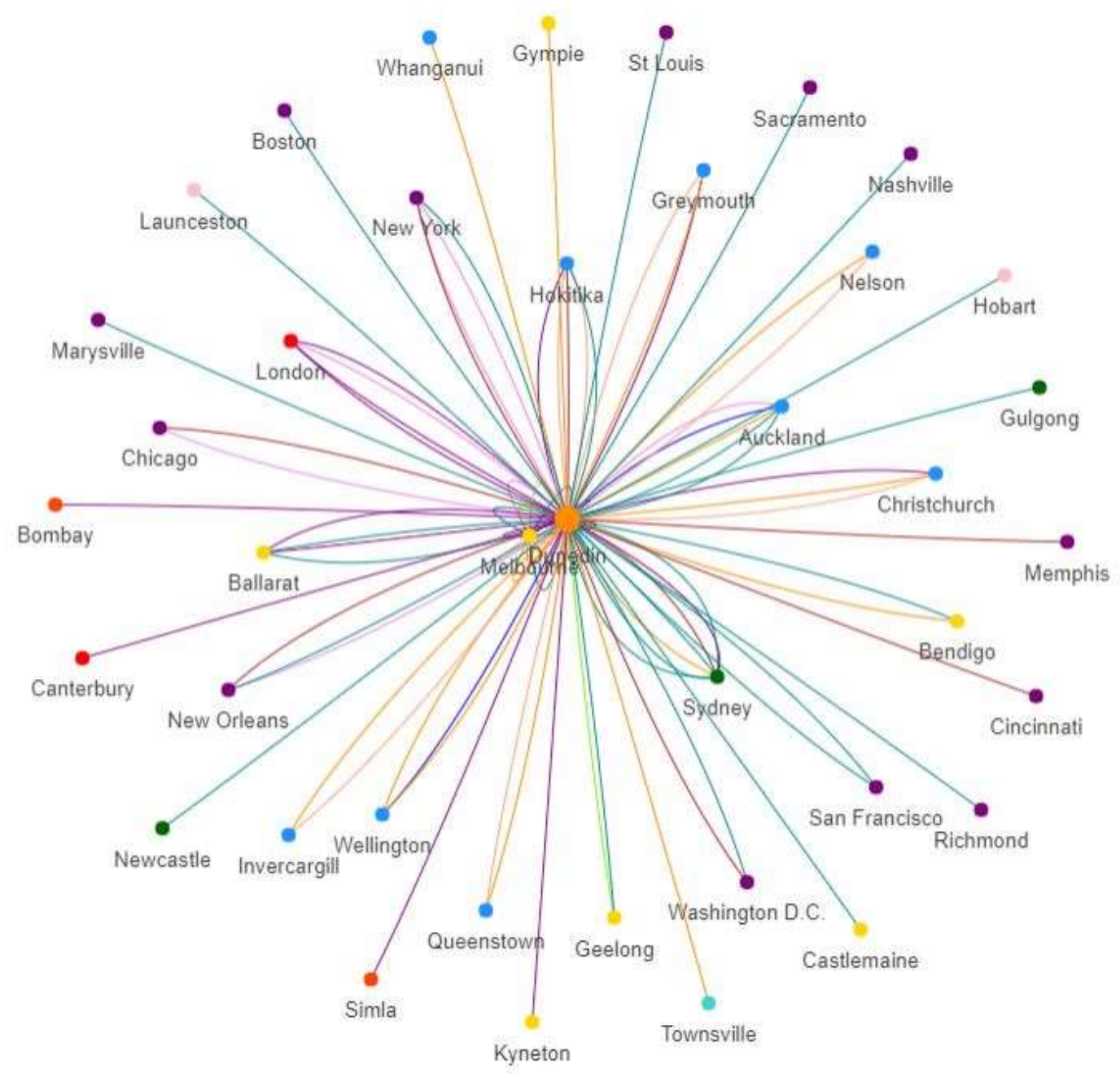

Node Key

Princess Theatre New Zealand Britain

India

NSW

Victoria

Queensland

Tasmania

USA
Link Key

Dolly Green

George Fawcett

Joey Gougenheim

Julia Mathews

Marian Dunn

Rosa Cooper

Sandford Fawcett

Tom Fawcett

Figure 2.2: Network map: Towns and Cities. The movement of the sample of eight actors connected Dunedin to more than forty other cities, towns, and smaller settlements in New Zealand, Australia, Britain, the United States, and India. Tom Fawcett, for example, arrived in Dunedin from Melbourne in 1862 and thereafter performed in Queenstown, Invercargill, Whanganui, Auckland, Christchurch, Nelson, and Wellington before touring Australia.

Network is best viewed digitally: www.entertainingprosepcts.weebly.com/networks.html 


\section{Network Map: Venues}

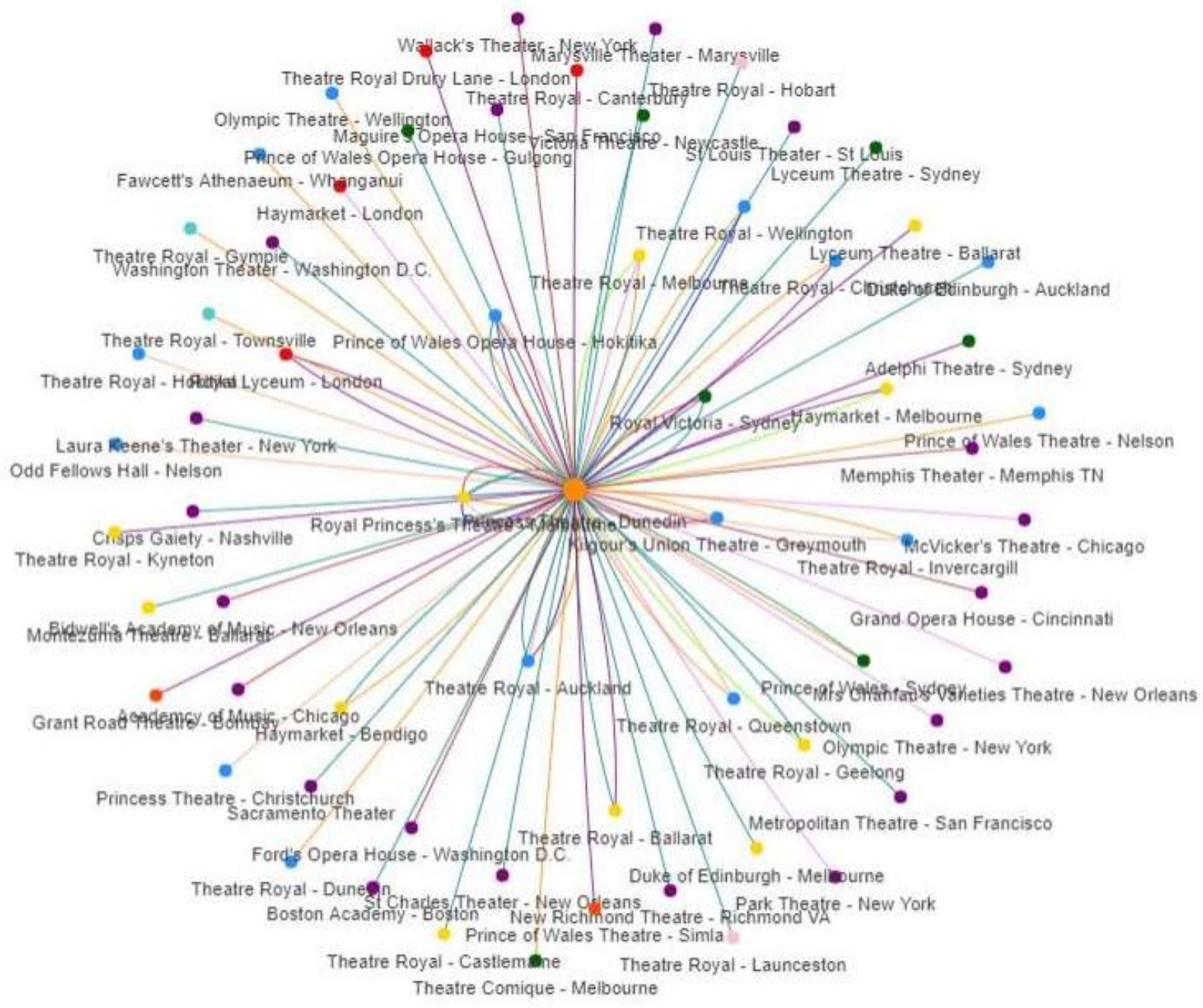

Node Key

Princess Theatre New Zealand

Britain

India

NSW

Victoria

Queensland

Tasmania

USA

\section{Link Key}

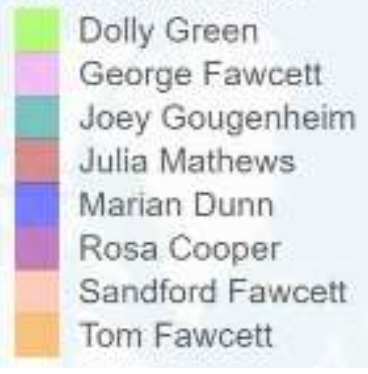

Figure 2.3: Network Map: Venues. The itinerant movement of the sample of performers linked the Princess Theatre in Dunedin to at least sixty-five other venues throughout the Anglo-world.

Network is best viewed digitally: www.entertainingprosepcts.weebly.com/networks.html 
During the mid-nineteenth century, most professionals treated New Zealand as a secondary stop, performing first in Australia - often coupling performances in Melbourne and Sydney with a stint on the goldfields in Bendigo or Ballarat - before venturing across the Tasman. Analysis of the network reveals the extent to which New Zealand's playhouses depended upon the success of Australian theatre circuits. The itinerant movement of performers forged links between Dunedin's theatres and at least twenty-two venues across Australia. During the 1860s, as gold discoveries in the South Island increased the viability of professional ventures, many performers adopted Dunedin as their point of entry to tour New Zealand, typically setting sail from Sydney or Melbourne. While some ventured no further than the goldrush capital, the network of venues examined here highlights the extent to which the allure of gold enriched the theatrical scene further afield. Once in New Zealand, several took their talents to audiences in Christchurch, Invercargill, Wellington, Nelson, Whanganui, New Plymouth, and Auckland.

Laidlaw's analysis of colonial networks highlights the heterogenous connections between individuals across the British empire. Interrogating these diverse connections, she divides her analysis into that of 'weak' and 'strong' bonds. The latter existed, she argues, between individuals connected in several different ways through multiple networks. While the structure of the network presented here, illustrating connections between place rather than individuals, is different to that outlined by Laidlaw, it is possible to undertake a similar analysis. Strong connections existed between the Princess Theatre and several venues in Australia with multiple performers appearing in both locations. Six of eight sample members - Julia Mathews, Marian Dunn, all three Fawcett brothers, and Joey Gougenheim appeared at the Royal Princess Theatre in Melbourne, emphasising the strength of association between Melbourne and Dunedin as nodes within a wider theatre network.

Goldrush migration, coupled with the advent of regular steamship routes, strengthened the link between Otago and Victoria. Extending that analysis to Australia more broadly highlights the wider significance of trans-Tasman links for the development of New Zealand's colonial theatre scene. Multiple sample members also performed at the Royal Victoria in Sydney, the Haymarket Theatres in Melbourne and Bendigo, and the Theatres Royal Ballarat and Geelong. Gold-driven movement of playgoers and performers constructed strong links within New Zealand as well, particularly between Dunedin and the West Coast. Half of the sample (Sandford Fawcett, Joey Gougenheim, Julia Mathews, and Rosa Cooper) performed at Bartlett's Prince of Wales Opera House in Hokitika, and three (Rosa Cooper, Tom Fawcett, and Sandford Fawcett) appeared at Joseph Kilgour's Union Theatre in Greymouth.

Managers benefited from, and played a crucial role in constructing, trans-Tasman links which enabled them to secure contracts with talent performing in Victoria and New South Wales to bolster their companies. The entire inaugural company which opened the Princess Theatre in March 1862 were recruited from theatre circuits in Victoria and New South Wales. Across town at the Theatre Royal, managers Clarance Holt and James Le Roy brought a full company of seasoned entertainers from the 
Victorian circuit with them to Otago. ${ }^{59}$ Popular American actors Joseph Jefferson and J.H. Allen, and English comedic sensation Lady Emily Don were among those engaged by energetic theatre managers to perform in Dunedin following tours in Australia. The enterprise of Dunedin managers benefited theatre in New Zealand more broadly. In Hokitika, Bartlett went to great lengths to capitalise on the steady stream of talent disembarking in Otago and succeeded - through emphasis of his first-class venue - in contracting several colonial stars.

Comic actress Joey Gougenheim's career highlights the significance of goldrush activity and novelty as drivers of theatre networks. Wealth and significant population marked gold towns as ideal targets for touring performers. Such a pattern held true across the Pacific as rushes in California, Victoria, Otago, and the West Coast precipitated intensive periods of theatrical activity. Having established a professional reputation in these settings, many went on to perform in more 'civilized' centres of commerce and population. Joey, the youngest daughter of solicitor Augustus Gougenheim, began her career performing as part of a double act with her sister Adelaide at the Metropolitan Theatre, San Francisco in $1855 .{ }^{60}$ Soon, the Gougenheim sisters were entertaining audiences in towns servicing the California diggings, remaining, predominantly, on the Valley Circuit, where they played engagements in San Francisco, Sacramento, and Marysville without venturing further into the hinterlands of the Sierra Nevada (figure 2.5). ${ }^{61}$

Building on a successful California debut, Joey and Adelaide set sail for Australia in 1856, to perform at Sydney's Lyceum Theatre. ${ }^{62}$ The season stunned critics and attracted 'the admiration of the press and public' by drawing large crowds for an unprecedented seventy-eight nights. ${ }^{63}$ Sydney performances were followed by an engagement at Ballarat's Montezuma Theatre in March 1857 which allowed the actresses to trial their talents in a new goldrush setting. ${ }^{64}$ Further performances in Victoria included four months at Melbourne's Princess Theatre and a short stint at the Haymarket in Bendigo. ${ }^{65}$ Returning to Melbourne in early December, Joey assumed the management and lesseeship of the Princess for a six-month season. ${ }^{66}$ Engagements in Ballarat and Ararat in April and June 1858, followed by a brief return to Melbourne, concluded the Australian tour and the sisters opened at Maguire's Opera House in San Francisco in November. ${ }^{67}$

\footnotetext{
${ }^{59}$ Clarance Holt, 'Twice Around the World or Recollections of an Old Actor', Ref: MS-224/2/1, NLA.

${ }^{60}$ Daily Alta (SF), 14 August 1855, p.3.

${ }^{61}$ McDermott, pp.18-28; Sacramento Daily Union, 7 September 1855, p.2; Marysville Daily Herald, 13

September 1855, p.2; Daily Alta, (SF), 6 October 1855, p.3; Sacramento Daily Union, 24 December 1855, p.3.

${ }^{62}$ Sydney Morning Herald, 26 September 1856, p.8.

${ }^{63}$ Star (Ballarat), 30 March 1857, p.3.

${ }^{64}$ ibid.

${ }^{65}$ Age (Melbourne), 24 July 1857, p.5; Bendigo Advertiser, 14 November 1857, p.3.

${ }^{66}$ Age (Melbourne), 2 December 1857, p.2.

${ }^{67}$ Star (Ballarat), 9 April 1858, p.3; Age, 18 June 1858, p.5; Portland Guardian (Dunolly), 19 July 1858, p.2; Age, 24 July 1858, p.1; Placer Herald (Auburn, CA), 6 November 1858, p.1; Daily Alta (SF), 19 November 1858 , p.1.
} 


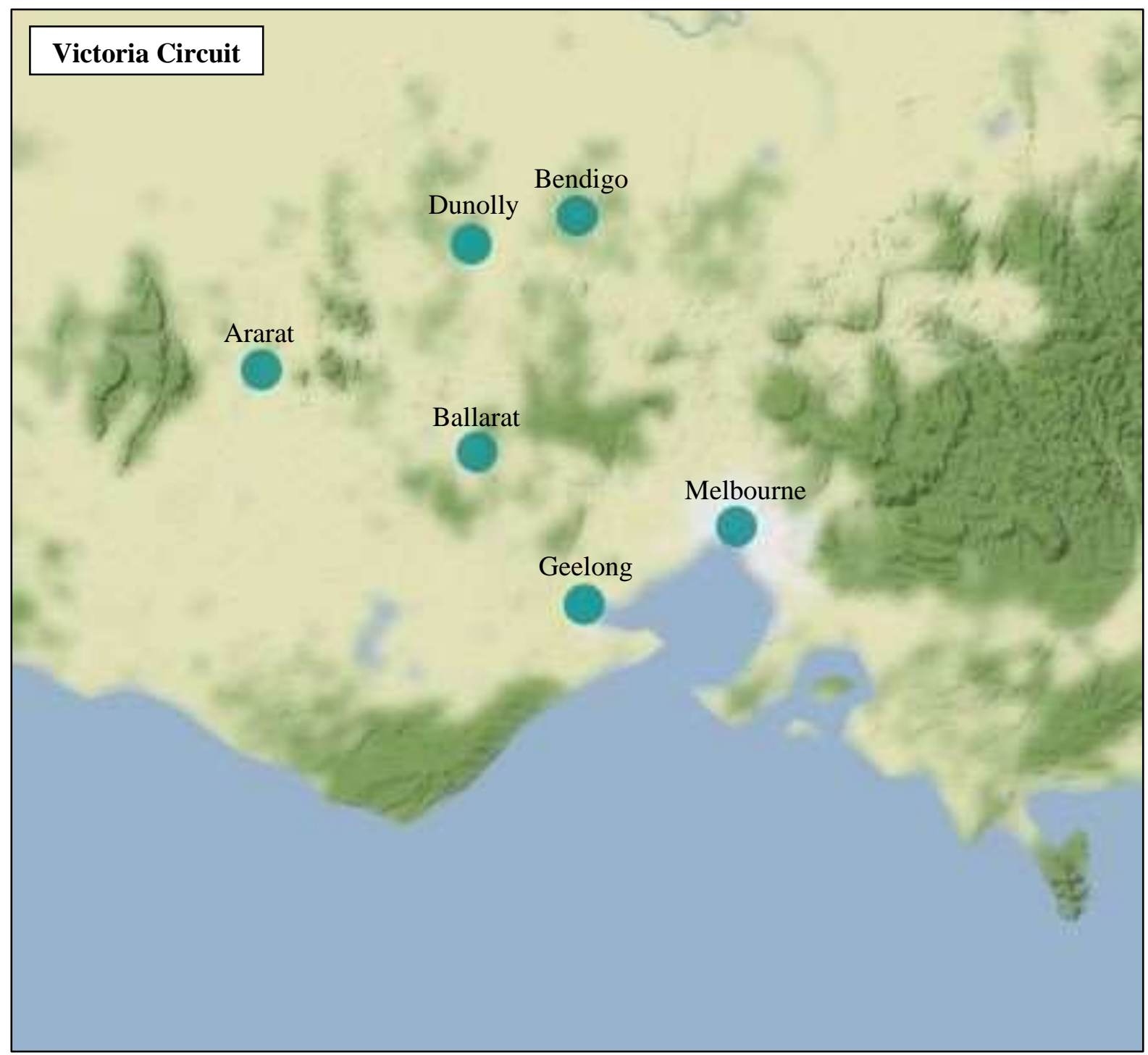

Figure 2.4: Victorian Goldfield Circuit. Melbourne was the theatre focal point with several significant playhouses - the Theatre Royal, Royal Princess's Theatre, and a colonial iteration of the Haymarket. Inland, Bendigo and Ballarat were significant theatre hubs. Smaller towns such as Dunolly and Ararat benefited from the pool of players these centres attracted.

Source: All maps, unless otherwise stated, are based on data from digital newspaper archives. 


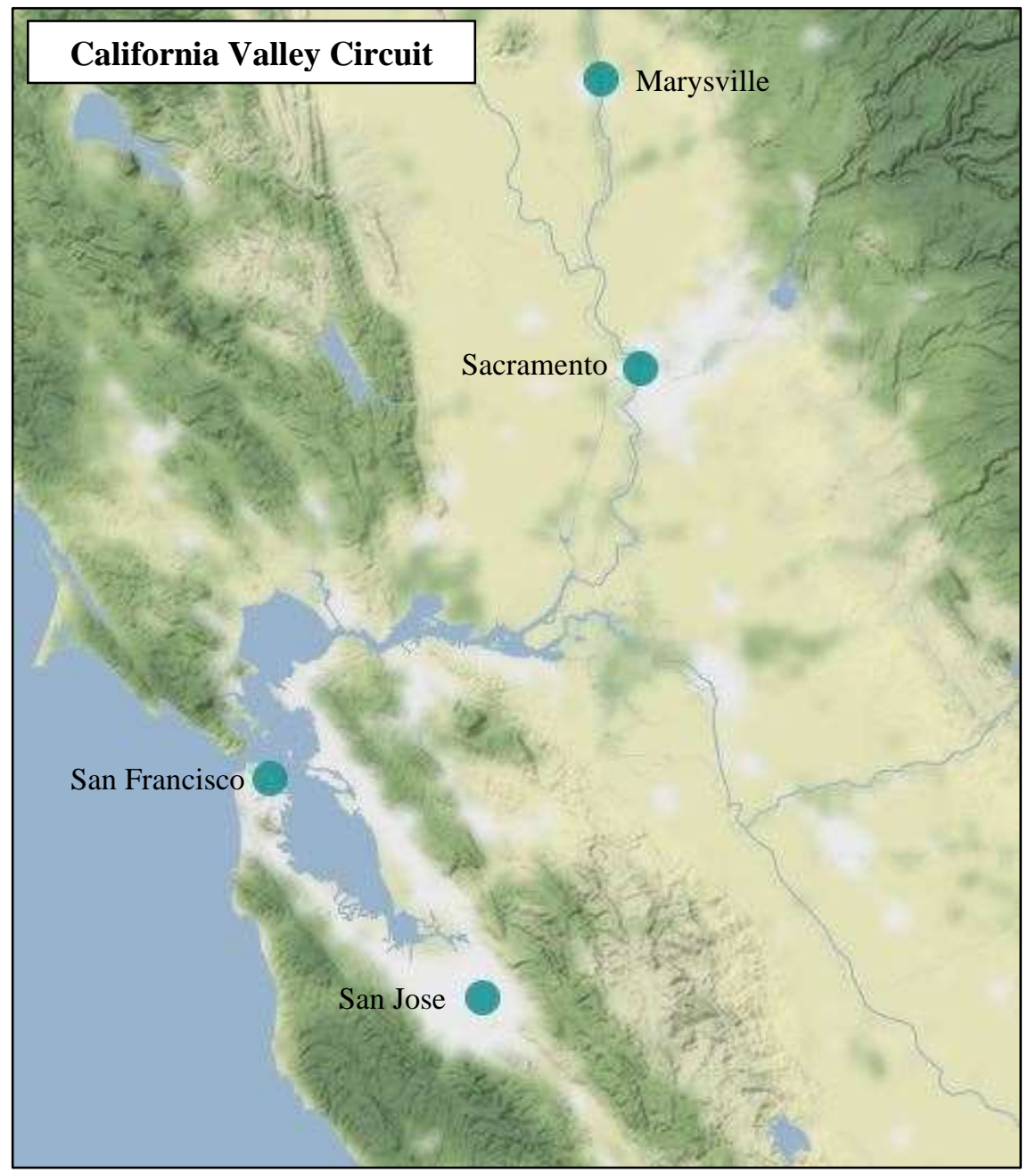

Figure 2.5: California Valley Circuit. San Francisco was the primary port of entry for touring performers arriving in California during the gold rush years. As supply towns were established further inland, along the Sacramento and Feather Rivers, regular touring circuits were established. The Valley Circuit connected theatres in Sacramento, Marysville, and Stockton with the energetic theatre scene on the coast and provided performers with a jumping off point for tours of smaller gold towns in the Sierra Nevada.

Source: McDermott, 'California’s Theatrical Frontier', pp.18-28.

Full map: www.entertainingprospects.weebly.com/maps1.html 
Wealth and reputation cultivated on the goldfields served the sisters well. In May 1859 they secured the management of the summer season at Laura Keene's Theater in New York - a popular playhouse which hosted premieres of Tom Taylor's Our American Cousin (1858) and Dion Boucicault's The Colleen Bawn (1860). ${ }^{68}$ New York offered entry to the theatre circuits of the eastern United States and the sisters subsequently commenced a tour - performing in St Louis, New Orleans, Mobile, Nashville, Richmond, and Boston before Joey departed to try her luck in London in June $1860 .{ }^{69}$ While described later as a 'pronounced success', Joey's stint in Britain was short-lived and she returned to Boston in December, before performing in Richmond, Washington D.C., Philadelphia, and Mobile in early 1861 (figure 2.6 ). ${ }^{70}$

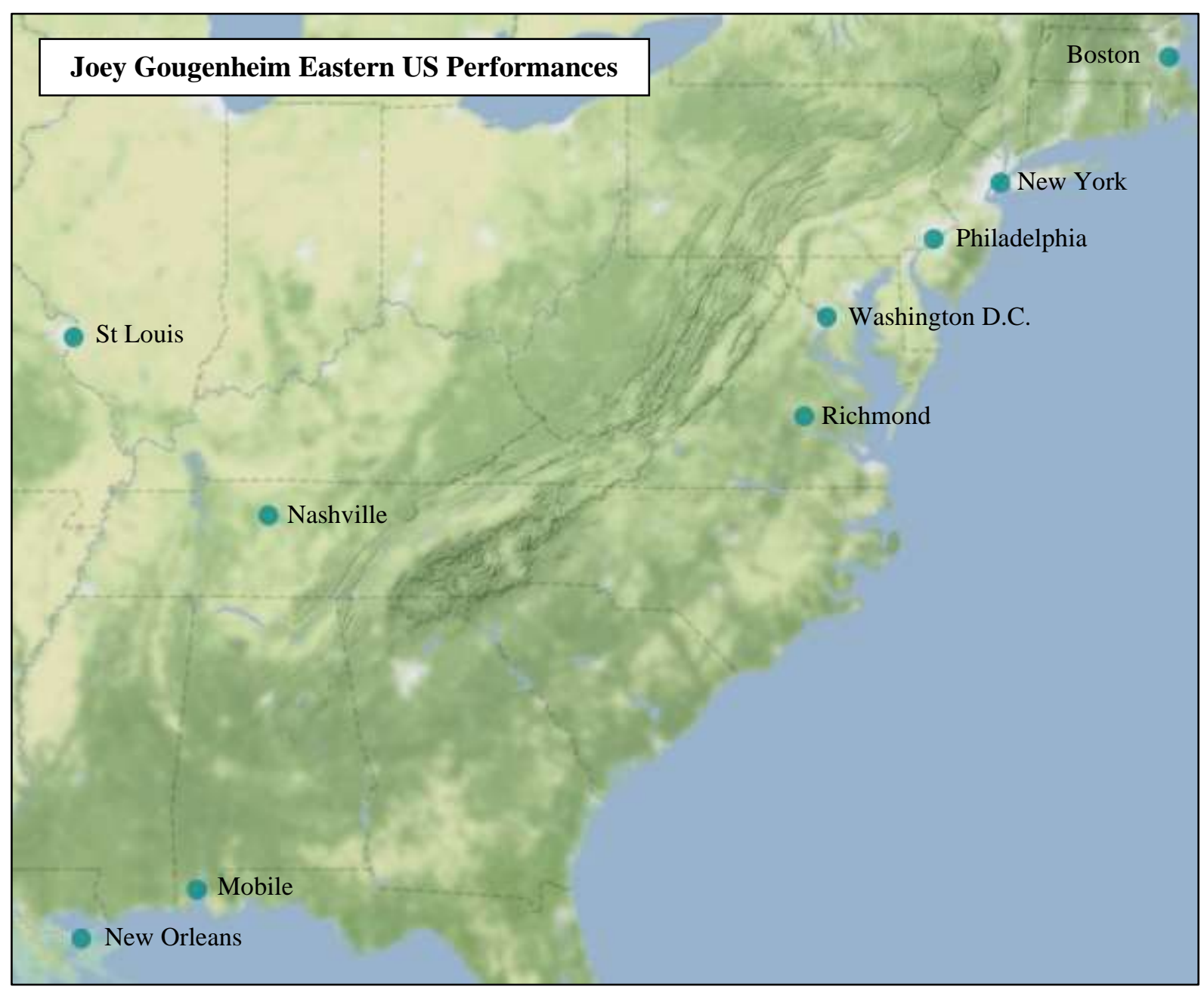

Figure 2.6: Joey Gougenheim's performances in the Eastern United States.

\footnotetext{
${ }^{68}$ New York Tribune, 28 May 1859, p.2; Dorothy Jean Taylor, 'Laura Keene in America 1852-1873', PhD thesis, Tulane University, 1966, p.183.

${ }^{69}$ Sacramento Daily Union, 8 September 1859, p.4; New Orleans Daily Crescent, 24 November 1859, p.1; Sacramento Daily Union, 12 January 1860, p.3; Nashville Patriot, 27 February 1860, p.2; Daily Dispatch (Richmond, VA), 12 March 1860, p.2; Sacramento Daily Union, 14 June 1860, p.8; Sacramento Daily Union, 26 June 1860 , p.1.

${ }^{70}$ Evening News, 13 September 1900, p.4; Sacramento Daily Union, 14 January 1861, p.3; Daily Dispatch (Richmond, VA), 11 January 1861, p.2; Evening Star (Washington D.C.), 21 February 1861, p.3; Sacramento Daily Union, 5 April 1861, p.2; Daily Alta (SF), 18 April 1861, p.1.
} 
In June 1861 Joey, now a well-travelled international favourite, re-joined 'a brilliant galaxy' of theatrical stars drawn west by the promise of accruing both prestige and wealth as California settled into more stable prosperity following the dissipation of goldrush fever. ${ }^{71}$ 'There are now in California' the Nevada Democrat noted, 'a greater number of dramatic stars than in any other part of the world. ${ }^{, 72}$ Among them was Joseph Jefferson who made his Dunedin debut as Rip Van Winkle at the Princess Theatre in January 1864. Several performances in San Jose with the San Francisco Metropolitan Theatre company concluded Joey's professional career in the United States and in March 1862, George Fawcett (by this time manager of the Princess Theatre, Melbourne) announced that he had contracted the popular comedian for a twelve-night season. ${ }^{73}$ This engagement was followed by her Tasmania debut, where she joined the Hobart Theatre Royal company from April until her farewell benefit before a 'crowded and brilliant audience' in July. ${ }^{74}$ For the next eighteen months Joey performed in Ballarat, Melbourne, Sydney, Bendigo, Castlemaine, Adelaide, Geelong, and Launceston. ${ }^{75}$ Finally, in September 1864, the Otago Daily Times announced that she had secured a contract with Joseph Wolfe, manager of Dunedin's Princess Theatre, who had travelled to Victoria with the purpose of securing 'engagements with artists of acknowledged ability. ${ }^{76}$

Having toured extensively, Joey's seasons in New Zealand were comparatively settled and lengthy. In July 1865, she married mining magnate Marmaduke Constable. Shortly thereafter, their first son was born. Three more children in the next five years may explain the slowing of Joey's itinerant movement as she opted instead for longer contracts in Auckland and Gulgong. It is also possible that, having successfully established herself as a colonial star, travel was no longer essential to secure audiences. Having cultivated a reputation of excellence, the novelty previously so integral to ensuring a captive pool of theatregoers could now be achieved by a change in programme rather than location. Joey visited few provincial locations in New Zealand, only appearing in Dunedin, Hokitika, Christchurch, and Auckland where sizeable or affluent constituencies of theatregoers were sufficient to ensure her continued success.

Other actors devoted considerable time, money, and energy to touring New Zealand. Dolly Green, who began her career in Victoria entertaining audiences in Melbourne and Geelong before her Dunedin debut as Ophelia in Shakespeare's Hamlet in May 1864, spent considerable time touring provincial Otago in $1869-70 .{ }^{77}$ Following two spells as 'directress' of the Princess Theatre in Dunedin,

\footnotetext{
${ }^{71}$ Nevada Democrat (Nevada City, CA), 12 October 1861, p.2.

72 ibid; $O D T$, 11 January 1864, p.6.

${ }^{73}$ Daily Alta (SF), 13 October 1861, p.4; San Jose Mercury, 24 December 1861, pp.2-3; Herald (Melbourne), 11 March 1862, p.8.

${ }^{74}$ Mercury (Hobart), 18 July 1862, p.4.

${ }^{75}$ Star (Ballarat), 31 July 1862, p.3; Herald (Melbourne), 7 August 1862, p.8; Sydney Morning Herald, 6 December 1862, p.5; Star, 16 February 1863, p.3; Bendigo Advertiser, 14 September 1863, p.1; Geelong Advertiser, 15 January 1864, p.2; Launceston Examiner, 2 February 1864, p.5; Adelaide Express, 19 May 1864, p.1; Sydney Morning Herald, 23 July 1864, p.1.

${ }^{76}$ ODT, 23 September 1864, p.4.

${ }^{77}$ ODT, 21 May 1864, p.4.
} 
Green toured a monologue entertainment entitled Seven Ages of Woman to many smaller towns in Central Otago including Lawrence, Saint Bathans, and Balclutha (figure 2.7). Similarly, Tom Fawcett, who embarked on his first foray in theatre management in March 1862 when he opened Shadrach Jones' Princess Theatre with his brother Sandford, built on that experience during the remainder of the decade. Beginning in Queenstown in 1863, Fawcett established several venues in Whanganui, New Plymouth, and Auckland with varying degrees of success before returning to Australia to try his luck on the Queensland circuit in 1867 (figure 2.8).

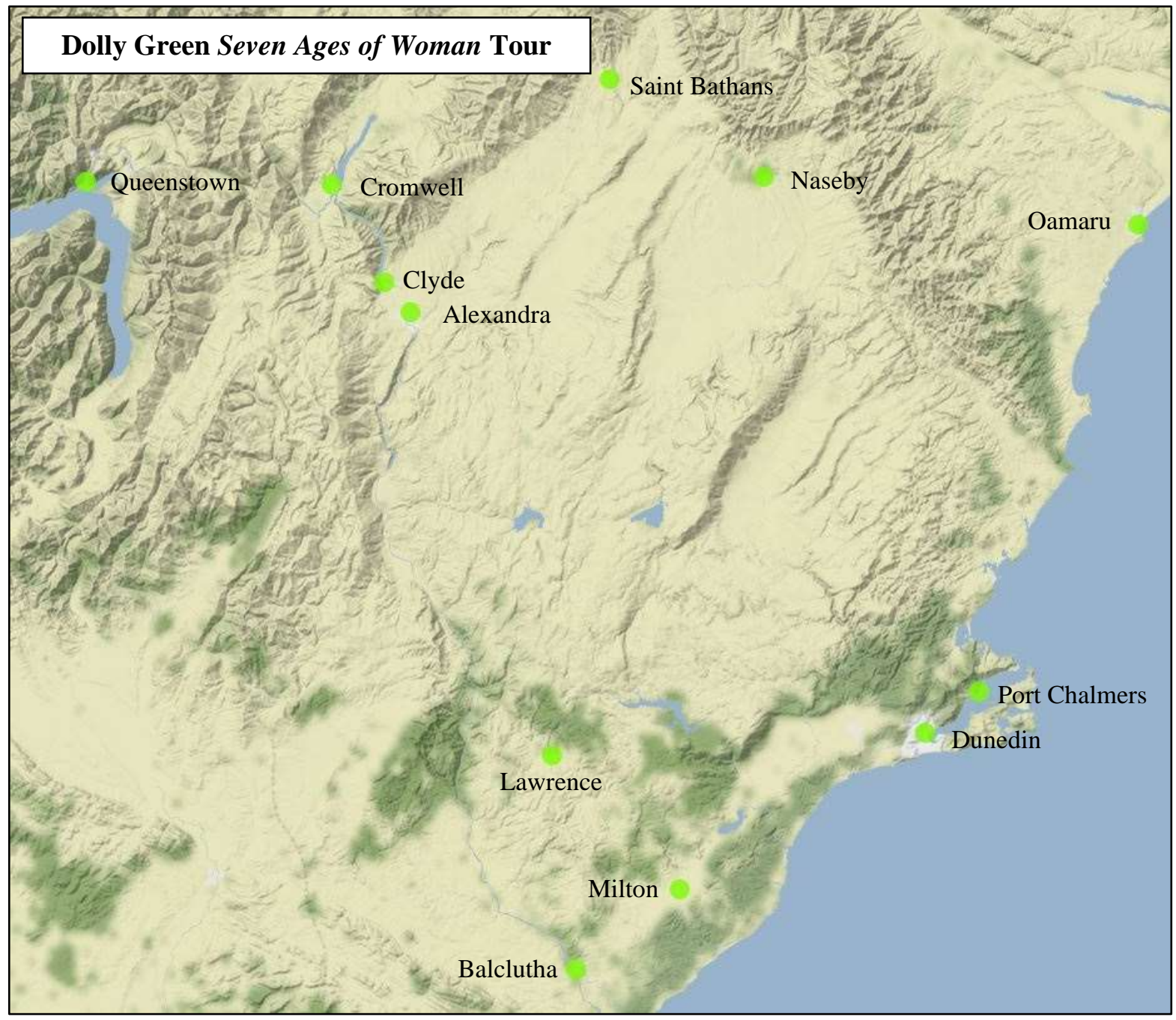

Figure 2.7: Dolly Green's tour of Otago between 1869 and 1870 highlights the increasing possibility for provincial tours during the focus period. Other big names limited their New Zealand appearances to centres of population or commerce, illustrating the potential financial risks of extensive touring. 


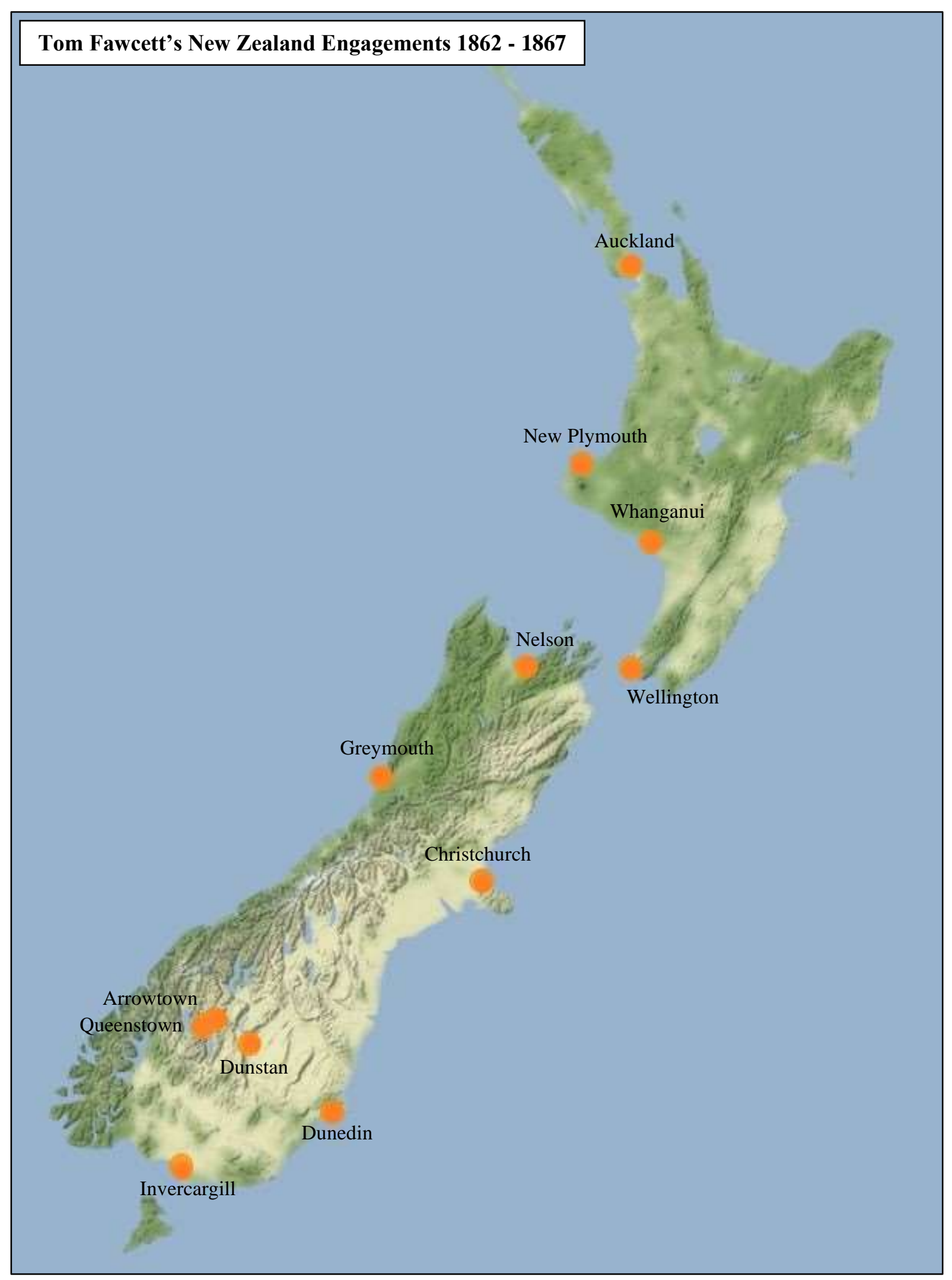

Figure 2.8: Tom Fawcett's New Zealand engagements. Theatre people attracted by gold in the south often toured elsewhere, demonstrating the extent to which gold rushes throughout Otago and the West Coast enriched and increased theatre activity in New Zealand more broadly. 
Comparing the touring patterns of sample members highlights the limited degree to which gender influenced theatrical itinerancy. Theatre offered performers, managers, and backstage practitioners, male or female, opportunities for travel which were limited in other occupations. A welltravelled resume bred esteem and increased public interest. Gender did not restrict female performers' ability to move for work. In fact, as Lippert has argued, the appeal, novelty and comparative sparsity of female performers, particularly in male dominated settings, often made itinerant movement more profitable for women who could capitalise on public intrigue to secure engagements. Female theatre stars, Lippert argues, 'occupied a privileged role' during the nineteenth century, possessing a 'gendered advantaged' which existed 'in part because there were so few of them. ${ }^{78}$

It is worth examining the extent to which Joey Gougenheim's patterns of movement reflected wider trends. Two further members of the sample - Julia Mathews and Rosa Cooper - also toured extensively. Cooper, an American tragic actress, began her career in New York before touring Britain and securing an engagement at London's Lyceum Theatre in the early 1860s. She then utilised her metropolitan experience to jumpstart a successful career on the colonial stage, making her debut in Ballarat on 23 November 1863, where her previous experience on the West End was heavily publicised. ${ }^{79}$ Shortly thereafter, she debuted in Dunedin where success in Melbourne was emphasised over her connections with the British metropole ${ }^{80}$ Cooper performed in several locations during her tenure in New Zealand, including two spells of management in Dunedin and Christchurch, before she completed her final engagement in Hokitika and departed for Sydney in 1870. By 1876, she and her husband Lionel Harding were performing in Calcutta where she was promoted as a 'clever Australian actress. ${ }^{91}$

Burlesque star Julia Mathews' extensive career followed the opposite trajectory but exhibits similar themes. Born in London, Mathews first appeared on stage as an eight-year-old pianist in $1853 .{ }^{82}$ By 1854, her family had moved to Sydney where she appeared at the Royal Victoria as an 'infant prodigy from the London theatres. ${ }^{83}$ Following a brief spell in Tasmania, where she formed connections with several contemporaries with whom she would secure employment later in her career, Mathews found fame as a burlesque actress and opera singer performing for audiences in Ballarat, Bendigo, and Dunolly through the latter 1850s. ${ }^{84}$ Following this lucrative spell on the goldfields, she secured her first Melbourne engagement, appearing at the Royal Princess' Theatre. ${ }^{85}$ She arrived in Dunedin on 26 October 1863, promoted as 'the star of Australia. ${ }^{86}$

\footnotetext{
${ }^{78}$ Lippert, p.328.

${ }^{79}$ Star (Ballarat), 24 November 1863, p.2.

${ }^{80}$ ODT, 1 October 1864, p.1; ODT, 24 December 1864, p.4.

${ }^{81}$ Newcastle Courant, 19 October 1877, p.6.

${ }^{82}$ Era, 24 July 1853, p.1.

${ }^{83}$ Empire (Sydney), 25 August 1854, p.1.

${ }^{84}$ Argus (Melbourne), 22 October 1856, p.5; Portland Guardian (Dunolly), 17 April 1857, p.2; Bendigo Advertiser, 25 May 1857, p.3.

${ }^{85}$ Argus (Melbourne), 3 February 1863, p.8.

${ }^{86}$ ODT, 26 October 1863, p.6.
} 
Mathews remained in New Zealand for three years, appearing in Dunedin and Christchurch before travelling to the West Coast to perform at Bartlett's Prince of Wales Opera House and Kilgour's Union Theatre. ${ }^{87}$ She departed for Melbourne in 1866 and returned to Britain two years later with the backing of a substantial colonial reputation. Here, she set about restructuring her professional image, forming her own small touring company in 1869. Separating from her husband in 1870, Mathews' career continued to advance. In August 1875 she embarked on a tour of the United States, opening at Wallack's Theater in New York where advertisers underscored her association with the 'Royal Opera House, Covent Garden, London and the principal theatres of England, Ireland and Scotland. ${ }^{88}$

Throughout her career, promoters utilised Mathews' itinerancy to engage prospective audiences. Her transition from London prodigy, to Australian burlesque star, and finally to coveted prima donna of the Covent Garden Opera House, demonstrates the extent to which talent and reputation offered theatre people opportunities for travel and the ability to reinvent or restructure their professional, and to some extent personal, identities. Analysis of how performers were billed also provides some insight into the operation of theatre networks, and the significance of different nodes. On a global scale, Melbourne and Sydney were more significant centres of theatre culture than Dunedin and Hokitika. Cooper, for instance, transitioned from 'American tragedienne' to Lyceum star and then to 'Australian actress' during the 1860s and 70s but was never billed elsewhere as having performed in Dunedin. Likewise, Mathews appeared in Britain and the United States as a star from the Australian stage, despite spending considerable time in New Zealand.

Though stints in Dunedin and elsewhere proved financially lucrative and aided the development of several theatrical careers, performers did not typically remain in New Zealand long term. Excluding Sandford Fawcett, who died from heart complications in Hokitika aged twenty-eight, each of the sampled performers moved on to tour elsewhere. ${ }^{89}$ Tom Fawcett, Joey Gougenheim, and Marian Dunn went only as far as Australia. Fawcett departed for Melbourne in June 1867, performing there and in Sydney before embarking on a tour of Queensland. He died in Townsville on 16 April 1870 where he was working as manager of the local Theatre Royal. ${ }^{90}$ Gougenheim hopped back and forth across the Tasman several times. In 1871, she returned to Australia permanently where she managed the Prince of Wales Opera House in Gulgong for several years before her death in Sydney in 1900. ${ }^{91}$ Unlike her counterparts, Marian Dunn had a comparatively short career. She returned to the Melbourne stage in November 1865 before retiring following her marriage to local 'peripatetic philosopher' and novelist Marcus Clarke in $1869 .{ }^{92}$

\footnotetext{
${ }^{87}$ WCT, 27 August 1866, p.2; GRA, 25 September 1866, p.2.

${ }^{88}$ New York Herald, 4 August 1875, p.1.

${ }^{89}$ ODT, 14 September 1868, p.2.

${ }^{90}$ Mackay Mercury and South Kennedy Advertiser, 7 May 1870, p.4.

${ }^{91}$ Sydney Morning Herald, 18 July 1871, p.8.

${ }^{2}$ Author of For the Term of His Natural Life; ODT, 3 August 1869, p.3.
} 
George Fawcett, Julia Mathews, Dolly Green, and Rosa Cooper all went on to try their luck further afield. Fawcett departed Dunedin for the United States, opening at New York's Park Theatre in March 1865, and toured North America for several years before also succumbing to a heart condition in Manhattan on 29 August $1889 . .^{93}$ Mathews' appearance at Wallack's Theater was followed by engagements in Chicago, Washington D.C., Cincinnati, Louisville, New Orleans, Nashville, and Memphis. Shortly thereafter, plans for an extensive tour of the Midwest and California were curtailed when she died in St Louis on 19 May 1876. The reported cause of death was 'rheumatism and malarial fever' attributable, in part, to the 'weary travelling work and constant change of climate. ${ }^{94}$ Green returned to London where she continued to perform until her death in 1926. And, finally, following a series of management engagements in New South Wales, Cooper departed for India in 1876 where she became a fast favourite at the Grant Road Theatre in Bombay and the Prince of Wales in Simla. She died in Calcutta in $1877.9^{95}$

\section{Touring Companies}

Star performers on lucrative contracts benefited from travelling regularly, but a sizeable portion of working thespians sought more long-term employment. By the 1860s, most New Zealand theatres operated under a stock-company model with managers maintaining a company of actors to perform alongside visiting stars with whom contracts were frequently negotiated. Stock-company actors were typically employed for the duration of a season, but patterns of re-engagement meant that they could remain in the same city, if not the same theatre, for several months or years.

Travelling companies, the main source of professional amusement for New Zealand audiences during the 1850s, maintained their popularity during the 1860s. Examination of these groups has proven fruitful previously. Adrienne Simpson's analysis of touring entertainments in New Zealand in 1874 identified three categories of touring company. ${ }^{96}$ The first, and most common, were small touring groups of less than twelve. Often family-based, like the Kennedy family who toured their entertainment "Songs of Scotland", these small groups were profitable and travelled easily from place to place. Medium-sized companies, generally slightly larger dramatic companies, were also fairly common. Large groups of thirty or more, typically circuses or opera companies, were spectacular but incurred significant touring costs and were consequently less common. ${ }^{97}$

Addressing the developing theatre of the 1840s and 50s, Simpson notes that, on the whole, the industry during this period was 'ad hoc in nature and amateur in status. ${ }^{98}$ Professional tours were rare,

\footnotetext{
${ }^{93}$ New York Tribune, 30 August 1889, p.2.

${ }^{94}$ GRA, 1 September 1876, p.2.

${ }^{95}$ Newcastle Courant, 19 October 1877, p.6.

${ }^{96}$ Simpson, 'Entertainment on the Map', pp.153-176.

${ }^{97}$ ibid, p. 155 .

98 ibid, p. 154 .
} 
and it was not until after the influx of population and wealth precipitated by the Otago goldrush that attending professional theatre became 'a regular part of social life. ${ }^{99}$ By the 1870 s, Simpson suggests, the increased viability of resident theatre companies meant that nearly every settlement possessed buildings of suitable size to host stage entertainments. With a population influx generated, in part, by Julius Vogel's immigration policies which saw the population double between 1871 and 1880, more permanent theatrical ventures possessed both sizeable venues and a suitable pool of potential theatregoers.

Tracing six different companies, Simpson identifies three prerequisites for the development of a 'buoyant entertainment industry. ${ }^{100}$ First, enough discretionary income for managers to invest in venues and audiences to purchase tickets at reasonable prices. Second, a population large enough to sustain regular entertainments. Third, suitable geographic access. The last played a particularly critical role in shaping touring circuits. Places like New Plymouth were often bypassed by virtue of their lack of easy access by sea. ${ }^{101}$ Analysis of touring circuits during the 1860s supports Simpson's argument. All three requirements were met in Dunedin post-1861 when the flood of wealth from the goldfields, coupled with the influx of gold-seekers, precipitated the establishment of the Theatre Royal and the Princess Theatre. Similar developments occurred in Hokitika a few years later when the rush to the West Coast encouraged James Bartlett to invest considerable time and money constructing and decorating his Prince of Wales Opera House.

\section{Lyster's Royal Italian and English Opera Company}

During the 1850s and 60s, few entertainments attracted more attention than Frederick Lyster's Royal Italian and English Opera Company's five-month tour. Following success in Sydney and Melbourne, the company's arrival in Dunedin aboard the steamer Alhambra in August 1864 sparked much excitement among Otago's 'lovers of musical art. ${ }^{102}$ Contracted by Shadrach Jones, the company began a month-long engagement at the Princess Theatre, which had been specially renovated. Initially, ticket prices appeared too steep. Entry to the dress circle was $7 \mathrm{~s} 6 \mathrm{~d}$, a sharp increase from the typical $5 \mathrm{~s}$ charged for performances by the regular dramatic company. However, promoters argued, 'considering the heavy expense' incurred in transporting the group numbering nearly forty, 'the prices [could] be looked on as moderate. ${ }^{103}$ A significant investment, managers took a considerable risk when booking an act of this nature. If audiences did not show as expected there were few safety nets in place or opportunities for compensation. Fortunately, for Jones and the Princess Theatre, the Dunedin season

\footnotetext{
99 ibid.

100 ibid.

101 ibid, p.164.

102 ODT, 24 August 1864, p.4.

103 ibid.
} 
proved successful. The first performance drew $£ 200$, and the remainder of the season continued to attract large audiences. ${ }^{104}$

The 'high-class' entertainment was lauded by the press, with the Otago Daily Times noting that the remarkable success of the season proved 'that even in such an out-of-the-way place as Otago, highclass music [could] be appreciated.' 105 The social benefits of this brand of amusement were also noted. Papers declared the operatic performance was an 'unquestionably striking feature in the social advancement of the community. ${ }^{106}$ Response to the opera demonstrates the manner in which regular dramatic entertainments were perceived by Dunedin's social elite. The North Otago Times noted that the Lyster Company's run had turned the Princess Theatre into 'quite a picture of gaiety' with the renovations undertaken prior to their arrival transforming it into 'one of the prettiest of colonial theatres. ${ }^{107}$ However, while the visual and architectural distinction was a point of note, the greatest development, they suggested, was the "contrast between the present company of the dress circle and the usual audience secured by the dramatic company, when it was a dress circle only in name.' ${ }^{108}$

Following success in Dunedin, and one show in Port Chalmers, the company left for Christchurch where they were contracted for $£ 1500$ by J. L. Hall, manager of the Royal Princess Theatre, for a twelve-night season which was later extended by six nights for a further $£ 700$. Similarly criticised for 'extortionate' ticket prices (entry to the pit alone cost 7s 6d), Hall was quick to argue that these admission fees were necessary to cover the cost of engaging the company and conveying their baggage between Lyttelton and Christchurch. Accounting for the renovations made to ensure the best possible experience for patrons, Hall claimed the income from tickets would be 'only just sufficient' to cover his expenditure. Despite these criticisms, the Christchurch shows attracted enough support for the Company to consent to give two performances in Lyttelton prior to departing for Wellington in November 1864. On their first appearance in Wellington on 4 November, 'despite the wind and rain, a full house greeted the performers... and the plaudits shewed how much the audience were gratified with the various pieces performed. ${ }^{109}$ Subsequent performances in Nelson received a similar reception, and the Nelson Examiner and New Zealand Chronicle noted that the brief visit "could not be characterized, even by the surliest of critics, as anything short of an unqualified success. ${ }^{110}$

By the time they arrived in Auckland in mid-November the Company's success was preceding them and a full column advertisement appeared on the front page of the Daily Southern Cross on the day of their first performance. ${ }^{111}$ Ticket prices again proved contentious. The manager of the Prince of Wales Theatre had, ambitiously, booked the Company for a season of twenty-four nights, doubling the

\footnotetext{
${ }^{104}$ Wellington Independent, 1 September 1864, p.3.

${ }^{105}$ ODT, 6 September 1864, p.4.

106 ibid.

${ }^{107}$ North Otago Times, 15 September 1864, p.3.

108 ibid.

${ }^{109}$ Wellington Independent, 1 November 1864, p.3.

${ }^{110}$ Nelson Examiner and New Zealand Chronicle (Nelson Examiner), 12 November 1864, p.2.

${ }^{111}$ DSC, 15 November 1864, p.1.
} 
first contract made by the Princess Theatre in Christchurch. At $£ 3000$, the costs were too steep for ticket sales to cover and despite being 'liberally patronised' the early ambition proved too extravagant. 'The fact is' the New Zealand Herald reported 'it is utterly impossible for any city of the size of Auckland to ensure a nightly house of $£ 125$ [required to cover costs] for twenty-four consecutive nights; more especially when the prices are so high as those charged. ${ }^{112}$ Manager George Dalrymple had set admission at $10 \mathrm{~s} 6 \mathrm{~d}$ for the stalls, a price which - the Herald was quick to point out - was 'higher than those charged to Her Majesty's Theatre, in London. ${ }^{113}$ Returning south following their Auckland run, the Company performed again in Nelson and Wellington before sailing on for a return season in Christchurch in January 1865. They completed their New Zealand tour in Dunedin where, despite being less well received than on their first appearance, Lyster pulled a few good houses before departing for Melbourne in February.

The touring circuit followed by Lyster's Opera Company (figure 2.9, table 1) provides a useful representation of the importance of geographic accessibility for theatrical entertainment in the nineteenth century. All locations visited by Lyster were sites of reasonable population with seaward access enabling the company to take advantage of well-established shipping routes, typically, run by steamers. Smaller settlements such as Lyttelton and Port Chalmers benefited from their proximity to larger population centres and the performances in those two locations, with the Port Chalmers show staged in the local Masonic Hall, indicates that smaller population and lack of large purpose-built theatre venues were not the issues preventing the Company touring smaller towns.

Rather, touring was time consuming and expensive, as Hall and Dalrymple's woes illustrate, and taking large performances to smaller centres unlikely to provide suitable economic reward was not financially viable. Other companies toured more extensively during this period. The San Francisco Minstrels, for example, entertained in newly established Otago gold towns between November and December 1861. It is worth noting, then, the possibility that the brand of entertainment offered by Lyster and Co. was not in-keeping with popular demand in the gold towns. Where groups like the Minstrels could hope to do well with goldfield communities, Lyster benefited from providing would be urban social elites with a chance to engage with traditional 'high culture.' Such a narrative allowed managers to justify expenditure, ticket prices, and extensive renovations, and played a significant part in shaping the Company's success.

${ }^{112}$ New Zealand Herald, 30 November 1864, p.4.
${ }_{113}$ ibid. 


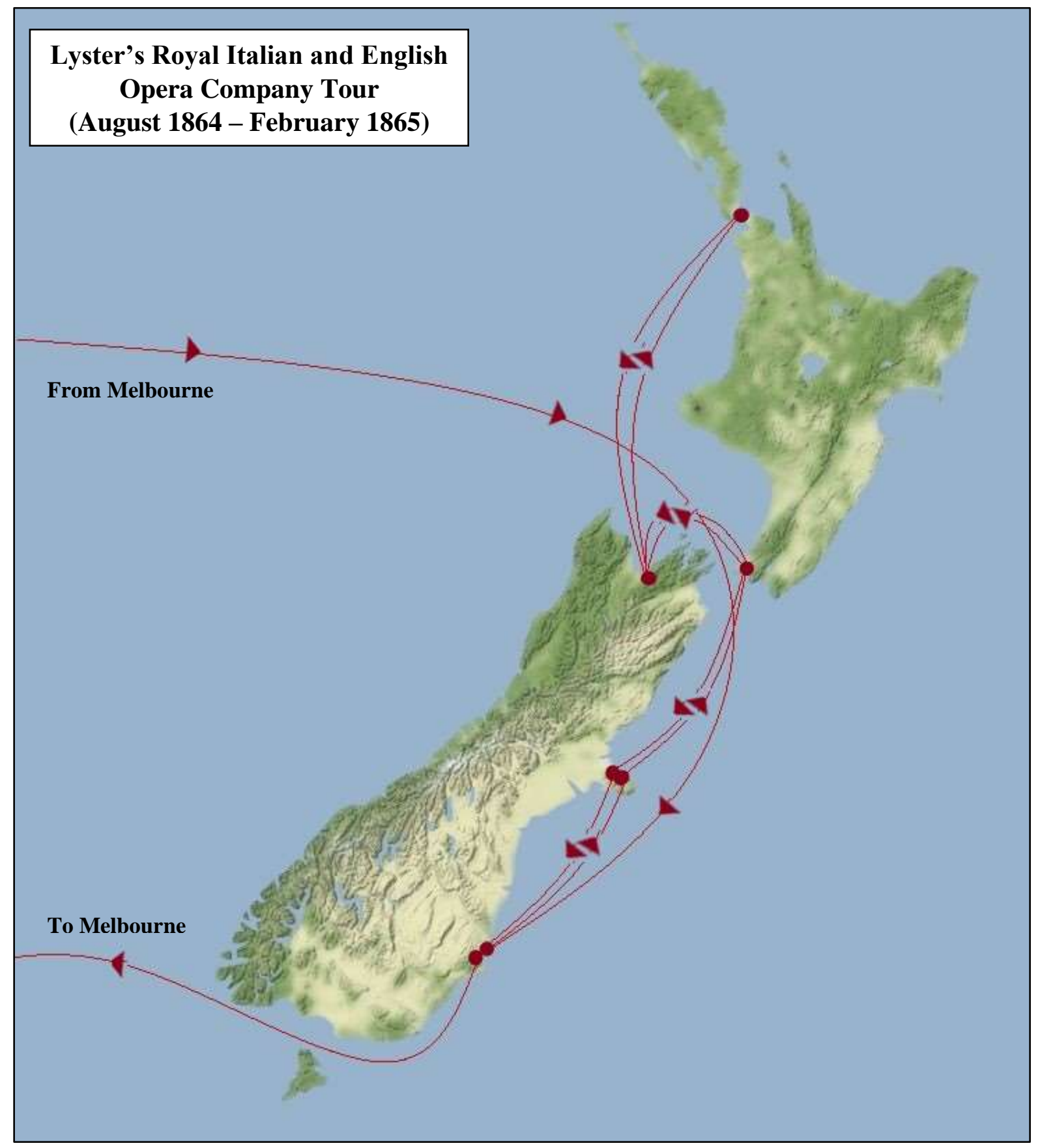

Figure 2.9: Lyster's Royal Italian and English Opera Company Tour 
Table 1: Lyster's Royal Italian and English Opera Company Itinerary

\begin{tabular}{|c|c|c|c|c|}
\hline Location & First Performance & Last Performance & Arrival Ship & Departed For \\
\hline Dunedin & 24 August 1864 & 3 October 1864 & Alhambra & Port Chalmers \\
\hline Port Chalmers & 4 October 1864 & 4 October 1864 & N/A & Christchurch \\
\hline Christchurch & 7 October 1864 & 27 October 1864 & Wellington & Lyttelton \\
\hline Lyttelton & 31 October 1864 & 1 November 1864 & N/A & Wellington \\
\hline Wellington & 4 November 1864 & 8 November 1864 & Queen & Nelson \\
\hline Nelson & 10 November 1864 & 11 November 1864 & Rangatira & Auckland \\
\hline Auckland & 15 November 1864 & 16 December 1864 & Wellington & Nelson \\
\hline Nelson & 20 December 1864 & 21 December 1864 & Wellington & Wellington \\
\hline Wellington & 23 December 1864 & 29 December 1864 & Wellington & Christchurch \\
\hline Christchurch & 3 January 1865 & 14 January 1865 & Rangatira & Lyttelton \\
\hline Lyttelton & 17 January 1865 & 18 January 1865 & N/A & Dunedin \\
\hline Dunedin & 23 January 1865 & 17 February 1865 & UNKNOWN & Melbourne \\
\hline
\end{tabular}

\section{The Lenton Troupe}

Another company touring New Zealand during this period, and offering a significantly different brand of amusement, was the Lenton Troupe - a group of acrobats and general circus performers. Arriving in February 1866, the Troupe's tour lasted two months, and they departed for Sydney from Hokitika in early April. Distinct from Lyster's Opera Company in both size and repertoire, the Lenton Troupe followed a different circuit which included the newly affluent and rapidly expanding Hokitika (figure 2.10, table 2). Contracted to appear at the Theatre Royal in Dunedin, the Troupe performed single nights at the Odd Fellows' Halls in Nelson and Wellington on their way through Cook Strait. ${ }^{114}$ These engagements were followed by a successful run in Dunedin from $12-22$ February, including an afternoon performance on Saturday 17 February for children and families. ${ }^{115}$

The Troupe's diverse entertainment - the likes of which was outside the realm of possibility for enthusiastic amateurs and thereby rarely accessible to colonial audiences - was hugely popular. With approximately ten performers the group was comparatively small but lauded by the colonial press as 'unrivalled' and 'world-renowned.' 116 The Troupe's four acrobats - brothers George, Thomas, and John Ridgway, and Leon Samwells - all garnered great praise from colonial critics. George Ridgway was a particular favourite, his mastery of the trapeze giving the West Coast Times cause to declare him

\footnotetext{
${ }^{114}$ Wellington Independent, 1 February 1866, p.5; Nelson Examiner, 3 February 1866, p.2.

115 ODT, 17 February 1866, p.4.

${ }^{116}$ Wellington Independent, 1 February 1866, p.5; Nelson Examiner, 3 February 1866, p.2; ODT, 10 February 1866, p.1.
} 
'surely the very prince and hero of acrobats. ${ }^{117}$ Other members of the Troupe included Herbert Skelton, a contortionist whose 'bending act' was much applauded, and Senor Luigi Ferrari whose trained monkeys while 'droll little brutes' proved laughable favourites. ${ }^{118}$ The monkeys were not the only animals accompanying the Troupe. Three dogs arrived in Lyttelton aboard the Airedale, but the role of the canines in the performance was less widely reported. ${ }^{119}$

Lenton and his company enjoyed a successful season and drew large crowds. In Christchurch, a performance at the Town Hall - which was large enough to accommodate the trapeze - was 'crowded to suffocation' and the first performance in Hokitika drew an audience which saw 'every part crowded' of the new Prince of Wales Opera House. ${ }^{120}$ Lenton's decision to include Hokitika is notable, and highlights both the significance of the increase in population facilitated by the goldrush and James Bartlett's investment in entertainment on the West Coast. Hokitika was not visited by Lyster's Opera Company, despite offering a potential stopover as they travelled to Melbourne in February 1865. A comparatively small settlement at that time, the soon to be bustling goldfield centre lacked both population and suitable venues. Compounded by the notoriously treacherous seaward hazard of the Hokitika Bar, the town held little attraction for touring groups. By 1866, gold-seekers converging on fields up and down the coast and rivers had generated a sizeable audience pool, and Bartlett's Opera House provided a suitable venue.

The Lenton Troupe's decision not to include Auckland in their circuit is a notable omission. While Lyster's Opera Company toured for the better part of six months, Lenton's tour lasted just over two. Even by steamer, the journey between Auckland and Wellington cut four days of potential performances and a seven-day trip south to Hokitika for a two-week season in what was by this point one of the wealthiest settlements in the colony proved more appealing. The Troupe had personally contacted Bartlett to secure the use of his venue and, familiar with the group's 'truly marvellous performances', he was quick to oblige. Lenton's itinerary highlights the extent to which gold towns, especially those accessible by sea, proved tantalising for touring companies in the nineteenth century. While access was risky, the lure of discretionary wealth and a sizeable theatre-going population placed Hokitika on the New Zealand touring circuit.

The tours of both companies highlight the extent to which, as Simpson has noted, the early entertainment industry in New Zealand was heavily biased toward southern centres. ${ }^{121}$ Wellington benefited from its proximity to Cook Strait but, excluding Auckland, no other North Island locations were visited by these two touring groups. As a result, patterns of theatrical touring support Tamson Pietsch's assertion that networks which connected 'far-flung parts of the world' did so 'in a highly

\footnotetext{
${ }^{117}$ WCT, 22 March 1866, p.2.

118 OW, 17 February 1866, p.11; ODT, 14 February 1866, p.4.

${ }^{119}$ Press (Christchurch), 26 February 1866, p.2.

${ }^{120}$ Press (Christchurch), 1 March 1866, p.2; Lyttelton Times, 22 March 1866, p.2.

${ }^{121}$ Simpson, 'Entertainment on the Map', p.163.
} 
uneven manner.' ${ }^{122}$ Touring companies navigated the Australasian theatre circuit in order to maximise their financial return. The fact that the North Island was largely excluded from these circuits while the gold in Otago and Westland brought professional entertainers to Dunedin in their droves highlights this point and demonstrates the extent to which networks of cultural transmission were shaped by the interests of different parties.

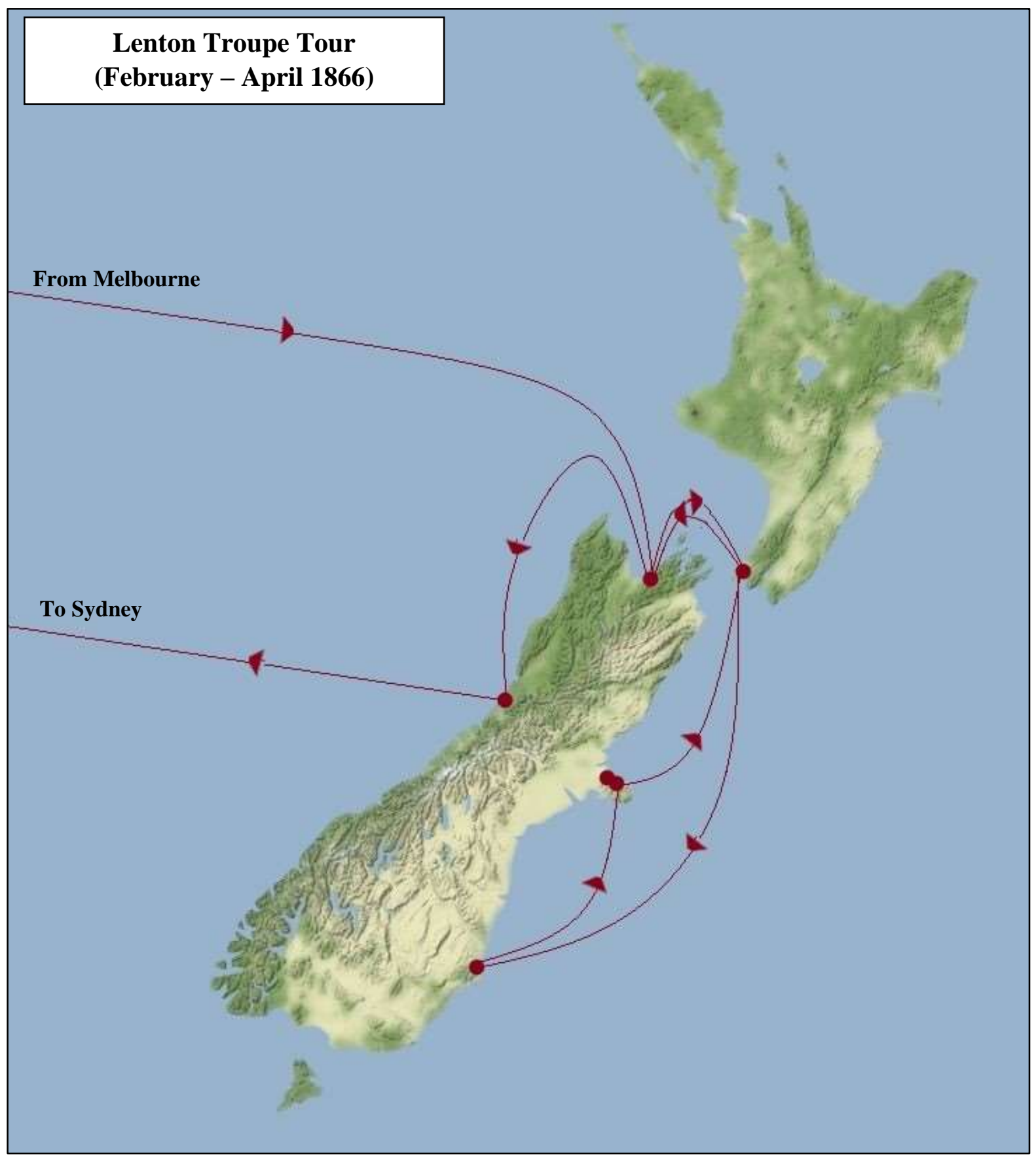

Figure 2.10: Lenton Troupe Tour

${ }^{122}$ Pietsch, p.448. 
Table 2: The Lenton Troupe Itinerary

\begin{tabular}{l|l|l|l|l} 
Location & First Performance & Last Performance & Arrival Ship & Departed For \\
\hline Nelson & 6 February 1866 & 6 February 1866 & Albion & Wellington \\
Wellington & 7 February 1866 & 7 February 1866 & Albion & Dunedin \\
Dunedin & 12 February 1866 & 22 February 1866 & Albion & Lyttelton \\
Lyttelton & 24 February 1866 & 24 February 1866 & Airedale & Christchurch \\
Christchurch & 26 February 1866 & 8 March 1866 & N/A & Wellington \\
Wellington & 10 March 1866 & 10 March 1866 & Egmont & Nelson \\
Nelson & 12 March 1866 & 12 March 1866 & Egmont & Hokitika \\
Hokitika & 19 March 1866 & 2 April 1866 & Egmont & Sydney
\end{tabular}

\section{Contemporary Popularity}

Alongside entertainment, managers recognised that patrons also used the stage to keep in touch with metropolitan trends. As a result, promoters consistently emphasised popularity in Britain or America to increase interest in their productions. The language used in promotional material enabled theatre practitioners and audiences in New Zealand to situate themselves within a global network of fashion and taste. At a basic level, this sense of place was conveyed through promotion of repertoire origin with advertisements highlighting the contemporary popularity of 'fashionable Haymarket' comediettas or 'new Lyceum' farces. ${ }^{123}$ Maintaining awareness of cultural trends in Britain was crucial, Lydia Wevers notes, for self-improving colonists attempting to assert their social status. Keeping up to date with literature and news 'was a never-ending work of cultural and historical maintenance', Wevers argues, 'in which being British (rather than 'colonial') was the unquestioned norm. ${ }^{\text {'24 }}$ Theatre served a similar purpose and popularity in Britain, or London more specifically, remained the marker of theatrical success throughout the nineteenth century.

Networks of theatre venues, and the constant movement of actors and managers, ensured that contemporary repertoire reached New Zealand with remarkable speed. Analysis of debut performance data from the Performance Database reveals that a sizeable portion of plays were staged in New Zealand within a decade of their first performance. In fact, some pieces were performed for audiences in the colonies while their debut season was still running on the West End. Theatre thus offered its colonial consumers access to repertoire currently playing in London, and other significant Anglo centres of fashion and commerce. Established classics which continued to entertain theatregoers across the Angloworld made up a smaller but sizeable portion of New Zealand's repertoire. The Rivals by Richard

\footnotetext{
${ }^{123}$ ODT, 27 June 1864, p.6.
}

${ }^{124}$ Wevers, Reading, p.49. 
Brinsley Sheridan (1751-1816), which debuted in 1775, was staged on several occasions in New Zealand during the focus period. Unsurprisingly, though perhaps less popular than expected, work by William Shakespeare was also performed.

Close examination of the contemporary popularity of plays sheds light on the cultural impact of the extensive theatre networks operating throughout the nineteenth-century Anglo-world. As they moved, theatre people carried with them access to, and knowledge of, different components of contemporary theatre culture. Be it the rights to a particular play, familiarity with a specific role, or experience producing certain effects, this knowledge and connection transported theatrical repertoire and convention to widely dispersed Anglo-settlements. Subsequently, building on Nina Auerbach's observation of widespread engagement and accessibility in Victorian Britain, theatre came 'closer than any art... to becoming a universal language... providing a common audience with common visions. ${ }^{125}$ Integrating theatre into studies of popular culture enriches our understanding of the broader role of culture in colonial societies. Examining the production and consumption of music, literature, and theatre provides scope to analyse how culture constituted relations of empire, as well as interrogating the extent to which it succeeded in transcending imperial boundaries. Recent work on sheet music by Jean Clare Gleeson highlighted New Zealand consumers' interest in popular forms of entertainment, opting for 'music of the moment' over more traditional compositions. ${ }^{126}$ Incorporating the stage into this analysis demonstrates how theatre enabled New Zealand audiences to keep pace with contemporary popular culture in Britain and North America. Additionally, examining the simultaneity of performance on a global scale contributes to discussions of space and place which continue to occupy scholars of empire.

Charting contemporary performances in Britain, the United States, Australia, and India of five plays staged in New Zealand between 1856 and 1868, the following analysis highlights the degree to which theatre enabled audiences in New Zealand to participate in wider cultural trends. John Maddison Morton's Box and Cox (1856-57 performances), Douglas Jerrold's Black-Eyed Susan (1867), Dion Boucicault's The Colleen Bawn (1867), Sheridan's The Rivals (1868), and Tom Taylor's Our American Cousin (1868) are the plays selected for analysis. The Rivals and Our American Cousin were popular comedies and Box and Cox, a successful farce. The Colleen Bawn was one of Boucicault's noted sensation dramas and its Irish themes provide a contrast to the Napoleonic War setting of Jerrold's melodrama Black-Eyed Susan. ${ }^{127}$

\footnotetext{
${ }^{125}$ Auerbach, p.6.

${ }^{126}$ Gleeson, p.i; Nelson Examiner, 14 January 1860, p.1; OW, 2 May 1863, p.1.

${ }^{127}$ Michael Slater, 'Douglas Jerrold', in Dennis Kennedy (ed.), The Companion to Theatre and Performance, (Oxford: Oxford University Press, 2010).
} 
New Zealand Performances of Black-Eyed Susan (1867)

Greymouth

Hokitika

Wellington

Christchurch

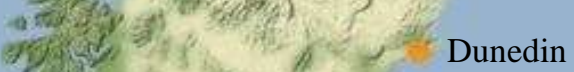

Invercargill

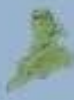

Figure 2.11: New Zealand performances of Jerrold's Black-Eyed Susan staged in 1867. 
The five pieces were written by playwrights of varying nationalities and backgrounds. Boucicault and Sheridan both heralded from Dublin, but Boucicault spent much of his professional career in the United States. ${ }^{128}$ The Colleen Bawn was one of several works by the Irish dramatist to make its global debut on the New York stage. ${ }^{129}$ Taylor, Morton, and Jerrold were all English-born and Taylor and Jerrold had worked, as editor and journalist respectively, for Punch. ${ }^{130}$ Taylor's Our American Cousin premiered at Laura Keene's Theater in New York in 1858. The other two pieces debuted in England, Black-Eyed Susan opening at the Royal Surrey Theatre in 1829 before several successful seasons at the Adelphi, and Box and Cox premiering at the Lyceum in 1847. ${ }^{131}$ While some, such as Black-Eyed Susan, were more popular with New Zealand theatre managers (figure 2.11), all five pieces were performed extensively in Anglo-theatres during the mid-nineteenth century.

Our American Cousin was among the most well-recognised comedies of the time but its contemporary, and subsequent historical, notoriety stemmed predominantly from the fact that Taylor's piece was on show at Ford's Theater in Washington D.C. when Abraham Lincoln was assassinated in 1865. Despite this unfortunate association, the comedy remained popular with Anglo audiences and continued to enjoy successful seasons throughout the remainder of the century. In 1868, when Taylor's work was performed for audiences in Dunedin, Hokitika, and Christchurch, it also appeared on stages throughout Britain, the United States, Australia, Canada, and India (figure 2.12). Rendered at the Princess Theatre in Dunedin in March, the same piece entertained theatregoers at Crosby's Opera House in Chicago, the Prince of Wales in Liverpool, and Piper's Opera House in Gold Hill, Nevada. ${ }^{132}$ A performance at the Theatre Royal in Newcastle in December featured former Dunedin favourite Lady Emily Don. ${ }^{133}$

\footnotetext{
${ }^{128}$ Richard Allan Cave, 'Dion Boucicault', in Dennis Kennedy (ed.), The Companion to Theatre and Performance, (Oxford: Oxford University Press, 2010); Jane Moody, 'Richard Brinsley Sheridan', in Dennis Kennedy (ed.), The Companion to Theatre and Performance, (Oxford: Oxford University Press, 2010). ${ }^{129}$ Dion Boucicault, The Colleen Bawn or The Brides of Garryowen, (New York: Samuel French, 1869), p.2. ${ }^{130}$ Ann Featherstone, 'Tom Taylor', in Dennis Kennedy (ed.), The Companion to Theatre and Performance, (Oxford: Oxford University Press, 2010); Slater.

${ }^{131}$ Tom Taylor, Our American Cousin, (1869), p.2; Douglas William Jerrold, Black-eyed Susan, or, 'All in the downs', (New York: Clinton T. De Witt, 1854), p.2.

${ }_{132}$ Chicago Tribune, 30 December 1868, p.4; Liverpool Mercury, 19 December 1868, p.6; Gold Hill Daily News, 3 September 1868, p.2.

${ }^{133}$ Newcastle Journal, 7 December 1868, p.2.
} 


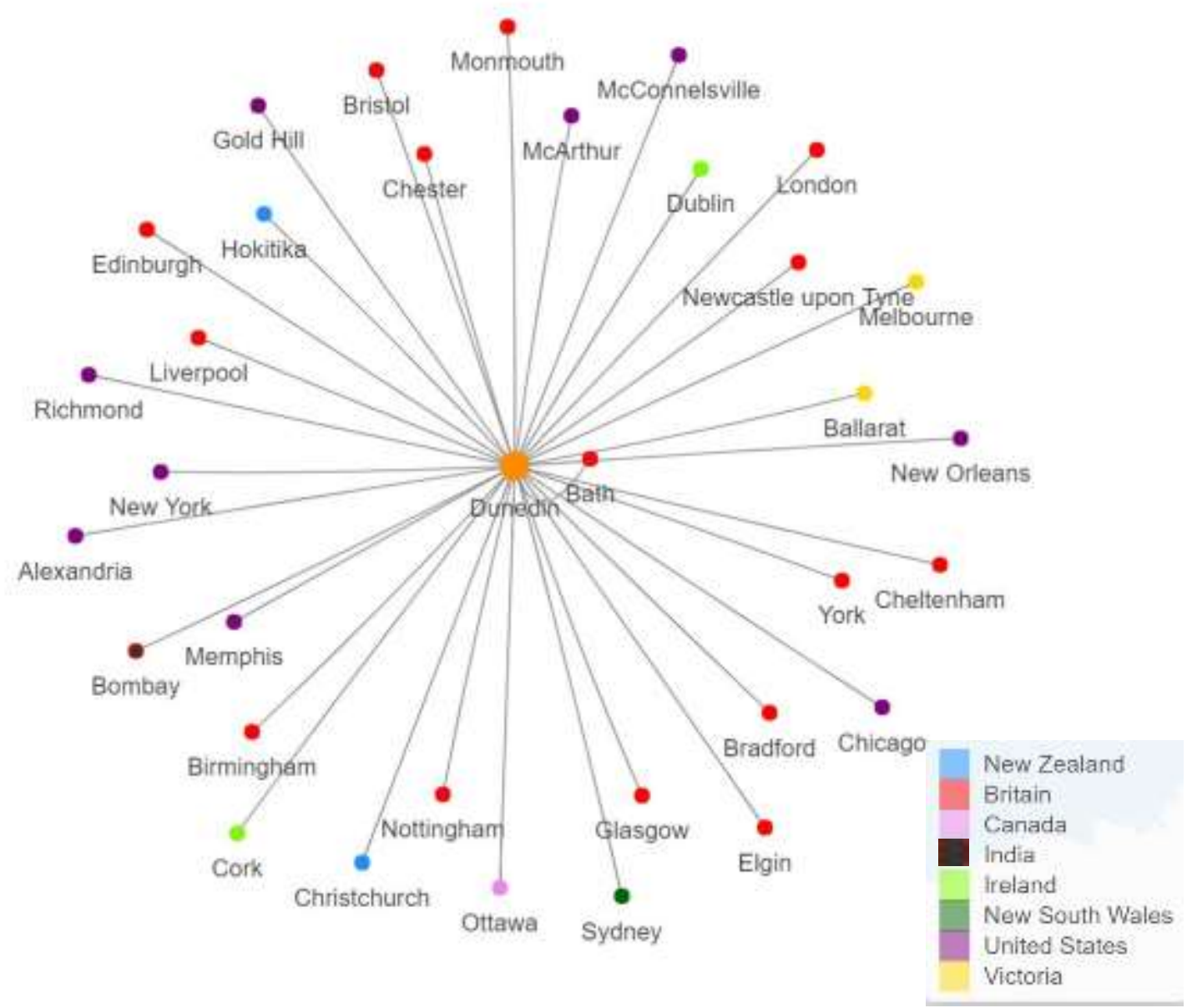

Figure 2.12: Network of performances of Tom Taylor's Our American Cousin, in 1868.

John Maddison Morton's work was particularly popular in garrison playhouses. Alongside Box and Cox (1847), military amateurs in New Zealand staged Morton's The Original (1837), The Sentinel (1837), The Irish Tiger (1846), Slasher and Crasher (1848), and A Most Unwarrantable Intrusion (1849) - all farces which had enjoyed varying degrees of success in London. Box and Cox, performed in Auckland and New Plymouth in 1856 and 1857, was staged in several other Anglo settlements during those two years. Alongside amateur productions in Nelson and Christchurch, the farce was popular with audiences in the United States (figure 2.13) and also enjoyed success in Victoria where it was staged in several smaller townships such as Forest Creek and Traralgon (figure 2.14).

Box and Cox's success highlights the extent to which garrison performers in New Zealand provided audiences with access to contemporary popular culture. Garrison theatres were temporary features of colonial society, lasting only as long as the regiment remained in a settlement or had idle time enough to devote to dramatic amusements. In New Plymouth, the garrison theatre at Marsland Hill closed as war engulfed Taranaki in the early 1860s. Restructured to house war stores, the theatre was re-opened briefly in late 1861 by the $57^{\text {th }}$ regiment. Shortly thereafter, however, the building was again 
requisitioned for more practical military purposes and the theatre was permanently closed. ${ }^{134}$ The movement of soldiers facilitated the spread of theatre culture - tracking paths, and constituting relations, of empire. Repertoire provided a tangible link between troops stationed throughout the British colonies from New Zealand, to Sydney, Cape Town, Montreal, and India. Selby and Morton were popular with garrison audiences in all locations. An 1858 performance at the Grant Road Theatre in Bombay, for example, featured a triple bill programme comprising Morton's Where There's a Will There's a Way and Take Care of Dowb, separated by Selby's Boots at the Swan. ${ }^{135}$

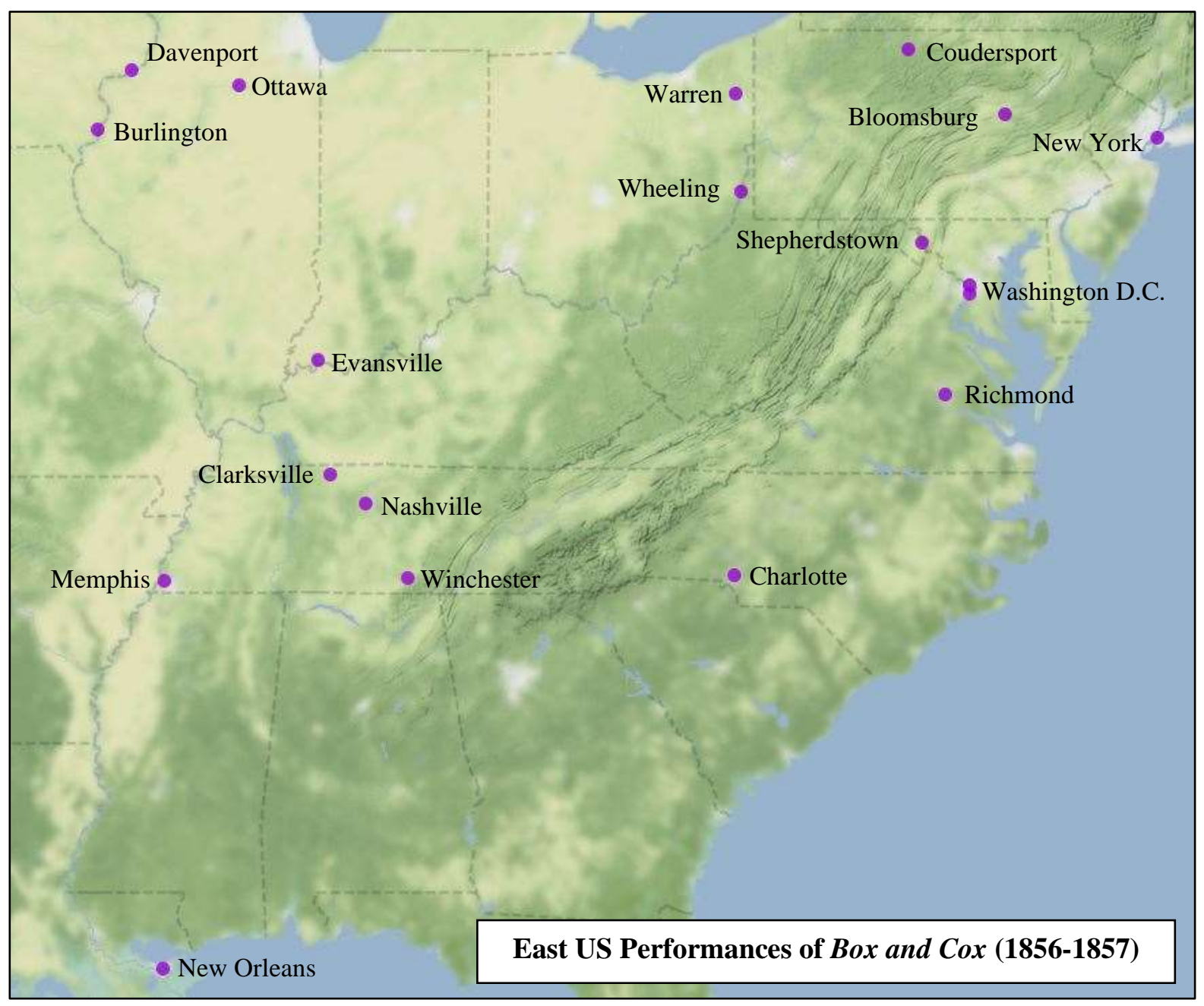

Figure 2.13: Performances of Morton's Box and Cox staged in the Eastern United States 1856/57.

${ }^{134}$ TH, 5 October 1861, p.2.

${ }^{135}$ Bombay Gazette, 12 May 1858, p.1. 

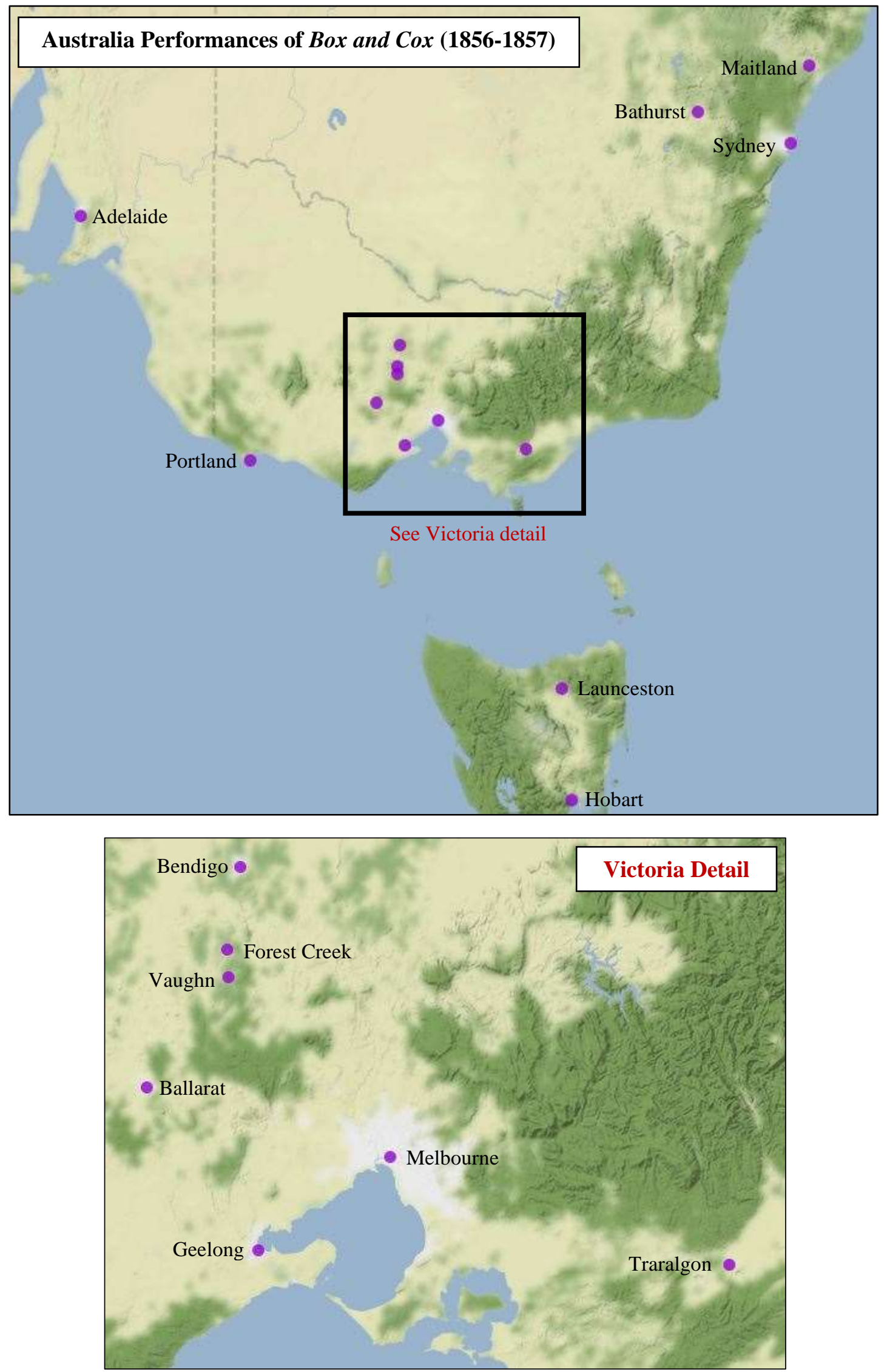

Figure 2.14: Australian Performances of Morton's Box and Cox in 1856 and 1857. The short farce was particularly popular in Victoria, staged in several smaller gold towns outside of the main theatre centres of Melbourne, Ballarat, and Bendigo. 
Sheridan's The Rivals, a comedy of manners, was staged many times in New Zealand, including several performances in Hokitika where one production in May 1866 was 'passed off very successfully' for the benefit of a full house at the Prince of Wales Opera House. ${ }^{136}$ On the West Coast, 21 per cent of plays performed between 1866 and 1869 were written by Irish playwrights, compared with 11 per cent of those staged in Wellington between 1850 and 1867. Sheridan's piece connected New Zealand's goldseekers to others on the Victorian goldfields, (with performances in Ballarat and Melbourne), British citizens in India (where it was staged in Bombay and Serampore), theatregoers on the East Coast of the United States and audiences throughout Britain. The 1868 performances of The Rivals, by this point part of the canon of legitimate drama in Britain, linked Dunedin and Hokitika to playhouses in Belfast, Dublin, London, Glasgow, and Edinburgh. Thus, while establishing connection with other colonial, or more exotic, locations, consumption of theatre culture also allowed theatregoers to experience common repertoire, stories and scenes being staged in towns and cities in Britain and Ireland.

Set in Bath, among the wealthy and fashionable English elite, The Rivals struck a sharp contrast with The Colleen Bawn, in which Boucicault employed themes of Irish nationalism, destitution, and land ownership denigration. ${ }^{137}$ Boucicault's piece found similar success with Dunedin and Hokitika audiences in 1867, and enjoyed great popularity globally. Capitalising on increasing demand for spectacle, the piece was popular with audiences in California, appearing in playhouses in four locations along the traditional valley circuit - San Francisco, Napa, Sacramento, and Marysville (figure 2.15). It also entertained audiences on the goldfields proper, with performances in Gold Hill, NV and Mokelumne Hill, CA - notable sites of goldrush activity during the 1850s. Both Boucicault and Sheridan's pieces were also popular in Ireland, where performances were widely advertised (figures $2.16 \& 2.17)$.

\footnotetext{
${ }^{136}$ Press (Christchurch), 4 June 1866, p.2.

${ }^{137}$ Deirdre McFeely, Dion Boucicault: Irish Identity on Stage, (Cambridge: Cambridge University Press, 2012), pp.13-28.
} 

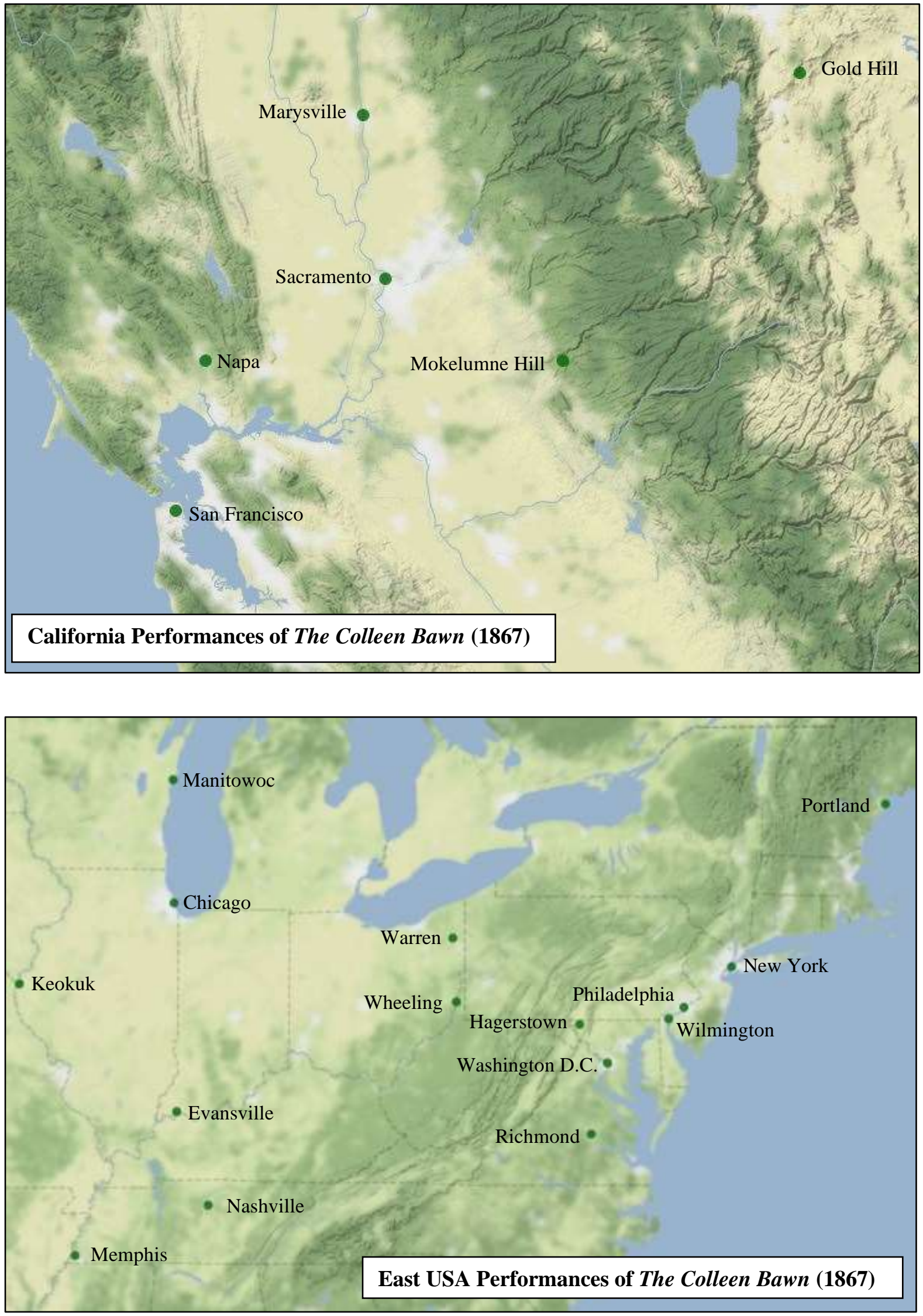

Figure 2.15: US performances of The Colleen Bawn (1867). 


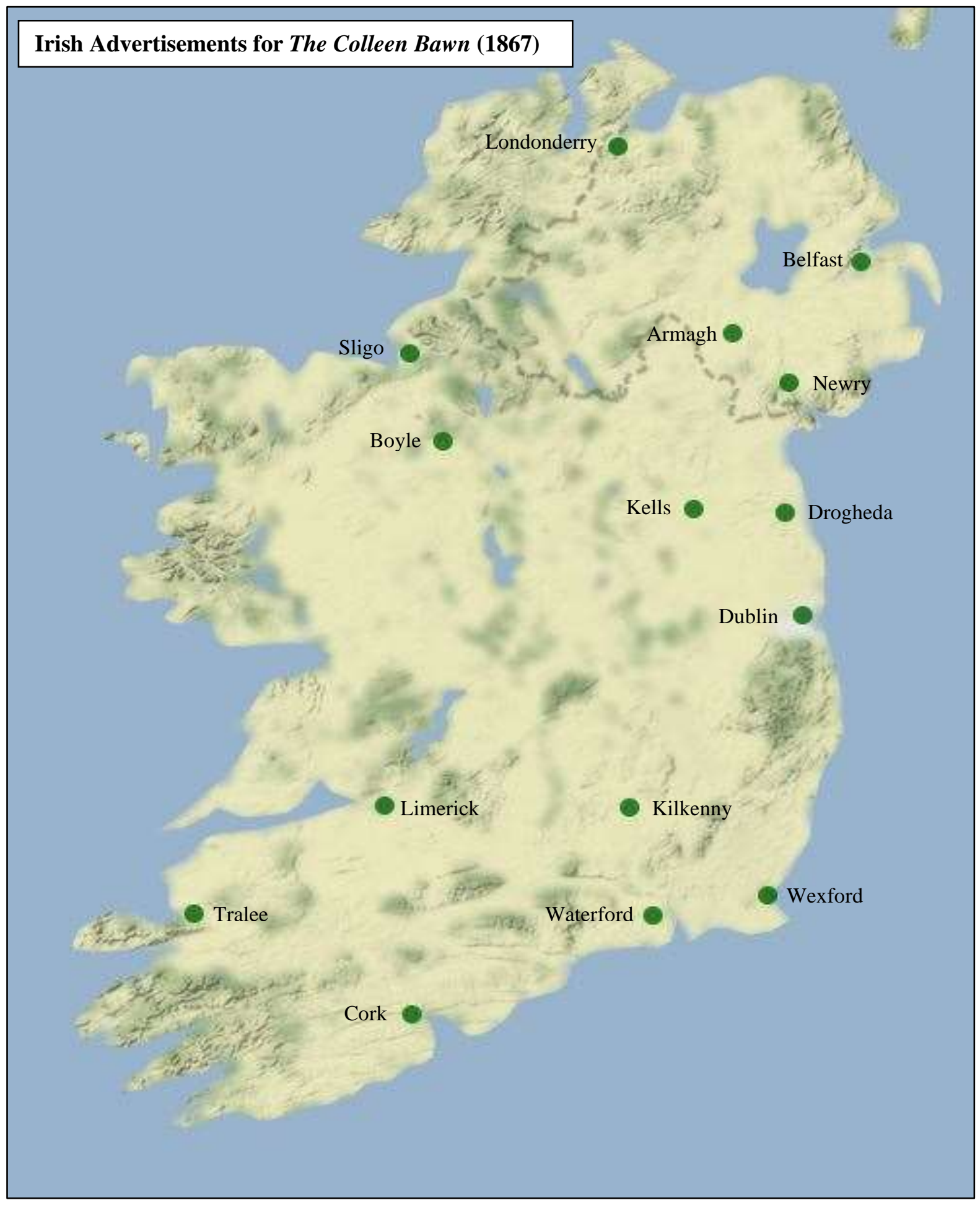

Figure 2.16: Irish advertisements for Boucicault's The Colleen Bawn in 1867. 


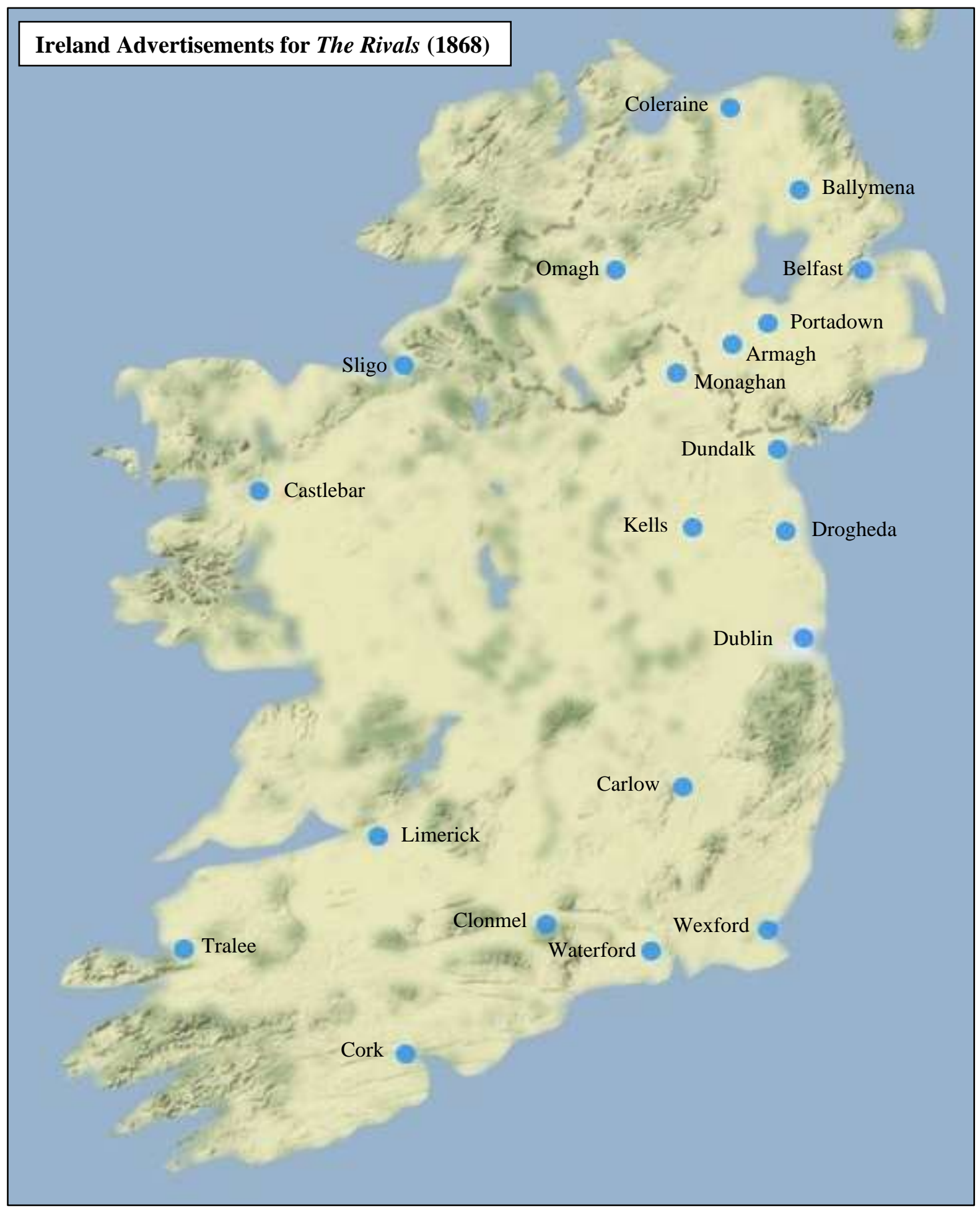

Figure 2.17: Irish advertisements for Sheridan's The Rivals staged in 1868. 
Analysing the mobility of theatre practitioners on the Western Australian goldfields, Dunstone and Grehan argue that, through the movement of Anglophone repertoire and performers, theatre spaces 'on all scales' constituted 'dislocated fields of social relations.' ${ }^{138}$ The common repertoire of Anglophone theatre constructed relationships between geographically dispersed populations, collapsing distance, and facilitating a sense of commonality with the wider Anglo-world. The extent to which the introduction of this brand of popular culture aided wider colonial agendas should be considered. Examining this process of cultural colonisation, Gibbons emphasises the role of the written word in constructing colonising narratives and visions of Pākehā society in New Zealand. ${ }^{139}$ Extending this analysis to the stage, the experience of theatregoing served dual purposes - constructing an imagined sense of place within the wider Anglo-world for theatregoers in New Zealand, and aiding in the development of a more immediate sense of community in new and transient colonial settlements through the emotive experience of the auditorium.

Theatre, novels, music and news were each fundamental elements of Anglo culture introduced by settlers to colonial societies during the nineteenth century. These cultural forms fostered a sense of shared identity within settler communities, bonding colonial populations together and preserving links with the imperial metropole and settler communities elsewhere. Binding disparate colonists through shared cultural mediums and reminding settler audiences of their place within a broader colonial narrative, theatre brought the empire to life on colonial stages in a manner which sought to naturalise colonial rule and reinforce the hierarchy of coloniser and colonised. Dion Boucicault's Jessie Brown provides an example of how theatre culture could be used to depict, and encourage audiences to sympathise with, other colonists. Empire was made in the colonial mind as well as on the land, and the introduction of Anglo theatre culture played a crucial part in this process.

Theatres were established in settlements, large and small, throughout the Anglo-world. Playgoers attending performances of Black-Eyed Susan at Kilgour's Union Theatre in Greymouth, or Our American Cousin at the Princess Theatre in Dunedin, could thus situate themselves within a wider constituency of audiences. Overcoming geographic distance, theatre constructed a network of social relations through shared experience which connected theatregoers in Greymouth with those in Dunedin, Melbourne, San Francisco, Edinburgh, and London. Theatre people, moving throughout this network, played a vital role in the construction of an imagined constituency of Anglophone theatregoers. Links between theatres throughout the Anglo-world also conveyed common repertoire, and broader social and business structures which shaped theatre work and the performance of gender. The extent to which theatres offered opportunities for employment and financial independence, often consciously inverting external gendered dynamics and challenging inherited expectations of labour and feminine domesticity, forms the focus of the next chapter.

\footnotetext{
${ }^{138}$ Dunstone and Grehan, 'Chaos' and 'Convergence', p.39.

${ }^{139}$ Gibbons, p.9.
} 


\section{Chapter 2}

\section{Theatre Work and Gender}

In February 1867, Greymouth residents seeking an evening's amusement filtered into the small theatre at Joseph Kilgour's Union Hotel. As the auditorium filled, theatregoers settled back in preparation for the upcoming performance - a rendition of Shakespeare's Romeo and Juliet featuring two contemporary stars. Rosa Cooper and Amelia Poole had received rave reviews for their performance of the classic tragedy the previous year at James Bartlett's Prince of Wales Opera House in Hokitika. ${ }^{1}$ As such, expectations were high as the curtain rose, and the two women stepped out onto the stage. Cooper, as expected, delivered a 'capital' performance as Juliet, playing with the 'delicacy and tenderness' befitting a respected performer and woman. ${ }^{2}$ Notably, Poole's Romeo was equally praised as a 'classical performance' with 'language, action and dress most appropriate and refined.' ${ }^{3}$ We 'must content ourselves' the Grey River Argus noted, 'with saying that altogether it was the best thing that has been seen on the boards in Greymouth. ${ }^{4}$

The two women appearing in leading roles were not an anomaly. Colonial theatre offered professional opportunities for both men and women throughout the nineteenth century, and women regularly became favourites with local audiences. As a place of work and commerce, the stage offers a distinctive space to analyse the performance of gender in colonial society. Performing in largely male communities to a predominantly male audience, female performers, particularly, challenged gendered codes of conduct and the operation of colonial gender norms. In addition, analysis of theatre women offers a fresh avenue to examine the diverse female experience of colonial societies. Examining the stage in garrison and gold towns, the following chapter investigates the conflict between theatre and wider gender dynamics in two predominantly homosocial environments.

Gendered imbalance in the colonial population shaped patrons' and performers' participation with the theatre as a public space. The colonial theatre remained, predominantly, a site of male sociability but women participated both as members of the audience and as performers and managers. ${ }^{5}$ Gold town populations were dominated by 'extremely transitory' young men without familial support. ${ }^{6}$

\footnotetext{
${ }^{1}$ WCT, 4 May 1866, p.2.

${ }^{2}$ GRA, 7 February 1867, p.2.

3 ibid.

4 ibid.

${ }^{5}$ David Burn, 'David Burn Diary, 10 October 1855 - 15 September 1858', Microfilm: CY 1094, Ref: 844931, Mitchell Library, Sydney; Mark Finnane (ed.), The Difficulties of My Position: The Diaries of Prison Governor John Buckley Castieau, (Canberra: National Library of Australia, 2004).

${ }^{6}$ Eichin, pp.26-27.
} 
Attending the theatre, therefore, offered men lacking female companionship the opportunity to observe a woman on stage. Analysis of the extent to which the scarcity of women in colonial settlements shaped public and critical response to female performers and managers enhances understanding of theatre as a space shaped by broader socialised gender norms and restrictions. Carolyn Eichin argues that, in California, population dynamics resulted in the presentation of theatrical programmes 'designed to meet male tastes. ${ }^{7}$ Commodifying female sexuality to appeal to male audiences, the uptake of variety theatre and subsequent boom in entertainments which 'promoted transgressive behaviours' and challenged wider interpretations and structures of gender provides an insight into the degree to which the stage reflected and defied its social surroundings. ${ }^{8}$

Theatres provided public spaces for entertainment and socialisation, but they were also places of business. This chapter examines the stage as a gendered place of work in colonial society. Beginning with an analysis of female performers and their public image in Britain, the study contends that, while subject to social expectations and restrictions, actresses in colonial New Zealand enjoyed a comparatively tolerant environment which largely respected the distinction between public entertainer and private woman. Examining theatre as business, the financial precarity of theatre employment and various challenges which faced colonial managers is discussed. Focusing on several women who played a significant role in ensuring the ongoing existence of a professional theatre scene in 1860s Dunedin, the chapter analyses how female theatre managers were viewed and measured in comparison with their male counterparts and colonial expectations of female domesticity. Exploring how gender was expressed or challenged on stage provides some space to examine the extent to which the distinction between performance and reality gave theatre license to invert wider social norms.

Gold town entertainments and the tradition of military dramatics offer an insight into the purpose and mechanics of theatre in male-dominated communities. Largely catering to the garrison, the military stage was a predominantly male space. Throughout the 1850s, however, garrison troupes in Auckland performed alongside female amateurs, and in New Plymouth female patrons were encouraged to attend, allowing these women limited but notable entry to the saliently masculine sphere of the British army. ${ }^{9}$ Unlike its amateur counterpart, profit-driven professional theatre sat within an explicitly commercial realm. Irrespective of genre, women performing publicly for pay unsettled wider social sensibilities which valued female domesticity. Debt was also a common feature of theatre work, and the financial precarity of theatre business played a significant part in shaping the lived experience of practitioners. Commercial professional theatre was, therefore, both morally and economically risky leaving performers vulnerable to accusations of immorality and leading many aspiring managers into financial strife.

\footnotetext{
${ }^{7}$ ibid, p.49.

8 ibid, pp.51-52.

${ }^{9}$ DSC, 19 September 1851, p.2; TH, 10 January 1857, p.2.
} 


\section{Women as Performers}

In Britain and Australia, actresses were subject to intense public scrutiny. Attitudes towards female performers in New Zealand, however, were comparatively relaxed. Female stars achieved just as much success as their male counterparts and their professional talents attracted supportive audiences across the colony. While some continued to argue against the propriety of women appearing on stage, for the most part their place within the theatre structure was well accepted and generally popular. In 1865, a religious publication condemning theatre as 'immodest, immoral and impious', and the actress as 'an outcast of society' who bore 'a doubtful character and a suspected name', was challenged by the editors of the West Coast Times for its 'violent strictures' and 'narrow point of view.' 10 'It is clear that the writer', the press noted, 'can have little practical knowledge of the actual condition and incidents of the modern Theatre. ${ }^{11}$

Theatre often consciously inverted gender norms in the name of amusement, prompting anxiety over the performance of gender on stage particularly by actresses who walked a fine line between respectability and indecency. ${ }^{12}$ As 'symbols of women's self-sufficiency and independence', the stage offered women a degree of autonomy rarely achieved in other occupations, but theatre's history of dubious morality profoundly affected contemporary perception of theatre women. ${ }^{13}$ Actresses lived public lives, hired for entertainment, which imperilled their reputations and blurred the boundary between the private and public sphere. While they enjoyed a degree of financial independence, the lives of female performers and theatre managers were inherently shaped by the fact that their place of work existed outside the realm of 'socially sanctioned occupations' for women. ${ }^{14}$

The stage offered women independence and power which, Kerry Powell argues, intoxicated actresses and 'imperilled' male dominance. ${ }^{15}$ Analysing the gendered dynamics of Victorian theatre in Britain, Powell suggests that, despite gaining access to various freedoms and opportunities, theatre women were also subject to repressive codes of gender. ${ }^{16}$ Posing a threat to the gendered structure of Victorian society by exerting control over the emotions of male patrons and directly challenging wider norms of female domesticity, actresses were often disassociated from ideal notions of womanhood. ${ }^{17}$ The apparent incongruence or 'irreconcilable opposition' between the public life of the actress and the idealised role of wife and mother regularly ostracised theatre women. ${ }^{18}$ Social and critical responses to

\footnotetext{
${ }^{10}$ WCT, 16 November 1865 , p. 2 .

11 ibid.

${ }^{12}$ Viv Gardner, 'Introduction', in Vivien Gardner and Susan Rutherford (eds.), The New Woman and Her Sisters: Feminism and Theatre 1850-1914, (Ann Arbor: University of Michigan Press, 1992), p.7.

${ }^{13}$ Davis, Actresses as Working Women, p.69.

14 ibid.

${ }^{15}$ Kerry Powell, Women and Victorian Theatre, (Cambridge: Cambridge University Press, 1997), p.3.

16 Powell, 'Power and Politics', pp.675-685.

17 ibid, pp.677-678; Powell, 'Gendering Victorian Theatre', p.357.

18 Powell, 'Power and Politics', pp.678-680.
} 
women on stage reflected broader discomfort with female independence. Playing on this popular anxiety, some contemporary repertoire attempted to reinforce gendered restrictions and male control. ${ }^{19}$

Contemporary equivocation of performers and prostitutes further restricted the supposed freedoms of theatre women. In an attempt to reassert control over actresses, Kirsten Pullen argues, 'the whore stigma was used to limit female experience and expression. ${ }^{20}$ With 'entertainment' available to all who could pay the fee, the commodification of both actress and prostitute enabled critics to draw damning parallels between the two groups. ${ }^{21}$ Arguments which condemned theatres and their workforce for association with the 'social evil' were not entirely unfounded.22 Powell suggests that the 'problematic...distinction between playhouse and whorehouse' was significant in this regard. ${ }^{23}$ Prostitutes frequented Britain's playhouses to solicit clients. Their presence negatively influenced the public perception of venues and performers and added credibility to anti-theatre criticism.

'Grades of respectability' separated leading ladies from chorus girls in Britain where female performers were often sexualised in an effort to undermine their independence. ${ }^{24}$ The noted histrionic abilities of the former commanded a certain respect from their audience, but comparatively little separated the latter from the common prostitute in public discourse. Tracy Davis argues that professional credentials and popularity acted as buffers which prevented speculation on a theatre woman's character irrevocably damaging her reputation..$^{25}$ Leading ladies of the legitimate stage, and highly popular performers of the more illegitimate, faced comparatively few accusations of immorality. Those singled out and condemned as whores and women of 'loose morals' were generally 'the lowest paid and least prestigious. ${ }^{26}$

Complaints constructed along class lines were unsubstantiated, not because they fabricated connections between theatres and prostitution but because those associations were weighted against the working class. Examining audiences, Jim Davis and Victor Emeljanow argue that accusations of immorality were utilised to undercut the respectability of certain groups of theatregoers. ${ }^{27}$ Prejudice against East End audiences was shaped by erroneous assumptions that 'any young person' in the gallery of a working-class venue 'must be either a thief or a prostitute. ${ }^{28}$ Tracy Davis notes, however, that 'no theatre, however lofty in patronage or repertoire, was free of prostitutes in the auditorium. ${ }^{29}$ Such patterns held true in colonial society. In 1864, evidence against Dunedin vagrant Allan McGuire

\footnotetext{
${ }^{19}$ Corsun, pp.21-37.

${ }^{20}$ Kirsten Pullen, Actresses and Whores: On Stage and in Society, (Cambridge: Cambridge University Press, 2005), p.2.

${ }^{21}$ Eichin, p.35; Powell, 'Gendering Victorian Theatre', p.358.

${ }^{22}$ Bratton, West End Stage, p.24.

${ }^{23}$ Powell, 'Gendering Victorian Theatre', p.358.

${ }^{24}$ Davis, Actresses as Working Women, p.77.

25 ibid.

${ }^{26}$ ibid, p.78.

${ }^{27}$ Davis and Emeljanow, pp.93-108.

${ }^{28}$ ibid, p.98.

${ }^{29}$ Davis, Actresses as Working Women, pp.81-82.
} 
revealed that he was 'nightly in and about the Theatre, in bad company' and regularly 'accompanied prostitutes to Cafes at the close of the performance. ${ }^{30}$ However, the paucity of professional colonial playhouses helped shelter the establishments and their female actors from any concentrated or ongoing accusations of immorality.

While colonial theatre resembled and, often, actively sought to replicate its metropolitan counterpart, the social factors which influenced its production and consumption differed from those at play in Britain. In colonial Bengal, Rimli Bhattacharya argues, the mere presence of women on stage was utilised as grounds for opposition by anti-theatre critics. ${ }^{31}$ Other colonial settings could be less restrictive, but theatre continued to exist in a morally ambiguous sphere. A stage career offered opportunities for travel which were, Eichin argues, particularly attractive and empowering for women. ${ }^{32}$ Fostering international reputations, extraordinary mobility, combined with the comparative lack of women in early colonial settlements, shaped the performance of gender on stage and theatre's interplay with the world beyond the auditorium. In a society intent upon proving its own respectable domesticity and settlement, theatre people's inherent transience and constant mobility was enough to set them at odds with wider colonial agendas in New Zealand.

In Australia, as in Britain, where the propriety of performers' private lives was a regular topic of discussion for both tabloids and middle-class drawing rooms, Jane Woollard notes that theatre women had to work hard to maintain their public reputations. ${ }^{33}$ The extent to which their line of work identified them as challengers to social constructions of respectable femininity often manifest as 'personal attacks in the press, snide comments from reviewers about their dress or figure, and assumptions about their personal morality and sexual availability. ${ }^{34}$ In New Zealand, by contrast, female performers were able to preserve the division between public and private woman to a remarkable degree. Catherine Bishop has noted that, while scandal and rumour may have remained a topic of conversation for the dining table or billiard room, few assertions of this nature appeared in the press where actresses were judged more on their professional ability than their figures or lives offstage. ${ }^{35}$ Some gendered criticism remained. Following a performance of Time Tries All in Auckland in 1856, David Burn wrote of leading lady Emily Glyndon that she was 'neither a pleasing actress or pretty woman. ${ }^{36}$ For the most part, however, public review focused most intently on a performer's histrionic success.

\footnotetext{
${ }^{30}$ ODT, 1 January 1864, p.5.

${ }^{31}$ Rimli Bhattacharya, 'Promiscuous Spaces and Economies of Entertainment: Soldiers, Actresses and Hybrid Genres in Colonial India', Nineteenth Century Theatre and Film, Vol.41, no.2, November 2014, p.52.

${ }^{32}$ Eichin, p.77.

${ }^{33}$ Woollard, p.10.

${ }^{34}$ ibid, p. 12.

${ }^{35}$ Bishop, p.262.

${ }^{36}$ David Burn, 'David Burn Diary, 10 October 1855 - 15 September 1858', Microfilm: CY 1094, Ref: 844931, Mitchell Library, Sydney.
} 
In addition to the generally more reserved behaviour of the press, a certain degree of stardom helped protect the reputations of women who made their living on the stage in colonial settings. Even in New Zealand, where criticism was less lurid, established standing as an actress was an advantageous buffer against accusations of immorality. The symbiotic relationship between press and theatre also ensured that newspaper proprietors supported the interests of both businesses. Analysis of how personal reputation, and the distinction between stage and reality, shaped gendered criticism highlights the extent to which more degrading forms of commentary were largely absent in New Zealand. The colonial career of popular burlesque performer Julia Mathews provides a useful case study in this regard.

Arriving from Melbourne in 1863, Mathews was an instant hit with theatregoers in Dunedin. Her double-bill debut performance as Josephine in the operatic drama The Daughter of the Regiment and Fra Diavolo in H.J. Byron's burlesque of the same name filled the Princess Theatre with a 'very brilliant' house which included a significant portion of 'the elite of Dunedin' and many women 'in full dress. ${ }^{37}$ Mathews continued to perform at the Princess with great success until April 1864 when she retired from the stage for a short period following her marriage to amateur dramatist William Henry Mumford. ${ }^{38}$ Retaining the maiden name under which she had established her reputation, she returned to the stage in July 1865 during her husband's tenure as lessee of the Princess Theatre. ${ }^{39}$ Mumford quickly ran into financial trouble, and in August 1866 the couple left Dunedin for Hokitika, where Julia had secured a contract with James Bartlett. ${ }^{40}$

Despite the genre actually privileging satire over more risqué conventions which dominated popular perception, female burlesque performers were treated with especial suspicion by critics in Britain and the United States who condemned their performance of female sexuality as a distinct threat to social stability. ${ }^{41}$ Perceived disregard for gender norms incensed some critics in New Zealand as well. Shortly after commencing her engagement in Hokitika, Mathews was targeted by several 'gross and inexcusable' accusations levied by a correspondent of the Colonist. ${ }^{42}$ The author, "Cameo", cast doubt upon Mathews' personal character, centring his criticism on her professional use of her maiden name which he felt sullied her husband's reputation. The complaints attracted swift condemnation from both the press and theatregoing public. The West Coast Times declared that Cameo, who was apparently well versed in 'theatrical matters and etiquette', should be ashamed for slandering 'a lady so universally respected' by objecting to her use of 'the professional name under which she first gained celebrity. ${ }^{43}$ A second correspondent, styling themselves Veritae, noted that Mathews was 'unequalled and unsurpassed on the Australian boards' as a star of comical burlesque. ${ }^{44}$ Aladdin, a third vocal defender

\footnotetext{
${ }^{37} O D T, 27$ October 1863, p.5.

${ }^{38}$ ODT, 25 April 1864, p.5.

${ }^{39} O D T, 24$ July 1865 , p.4.

${ }^{40}$ WCT, 27 August 1866, p.2.

${ }^{41}$ Pullen, p.93.

${ }^{42}$ WCT, 29 August 1866, p.2.

${ }^{43}$ ibid.

${ }^{44}$ WCT, 29 August 1866, p.3.
} 
declared Cameo would do well to remember 'that the lady who [was] the subject of his vile aspersions, [was] known and respected throughout the Australian colonies for her private virtues and great accomplishments. ${ }^{45}$

Cameo's opinion that Mathews' retention of her maiden name constituted a sign of moral corruption was very much in the minority. His argument that neglect of her married name degraded the masculinity of her husband, provides evidence, nonetheless, to support Powell's argument that female independence in the theatre could threaten wider gender structures and social constructions of masculine dominance. The practice of performing under one's own name was common in theatrical circles. Many famous British actresses retained the names under which they had established their independent reputations, and the lack of similar critique paid to local favourite Rosa Cooper (who performed alongside her husband Lionel Harding) highlighted Cameo's double-standard. ${ }^{46}$ Notwithstanding its normality in the theatre, the practice stood in stark opposition to more conventional social norms. Cameo's criticism garnered more backlash than support, but it provides evidence, nonetheless, of an insecurity generated by the dissonance between gender norms within the theatre and those which structured life outside the auditorium.

It is worth considering the extent to which the relative sparsity of women on the goldfields may have influenced public response to Cameo's accusations. The freedoms accessible to women, particularly young Pākehā women, in the gold towns often came at cost to their reputations. ${ }^{47}$ Dance halls and other entertainment venues offered high wages, but the raucous character of amusement left performers vulnerable to accusations of immorality. Women employed in the theatre were viewed as respectable providers of more reputable entertainment. In goldrush San Francisco, women enjoyed a 'gendered advantage' in cementing their position as theatrical stars because they were so few. ${ }^{48}$ The novelty of a feminine presence, combined with a prevailing 'male loneliness' and curiosity, enabled female performers to construct an image of celebrity with comparative ease. ${ }^{49}$ Barmaids even enjoyed a degree of celebrity status, and women as a whole were looked upon as novel symbols of social refinement. ${ }^{50}$ Criticism which degraded the reputation of the most esteemed of gold town entertainers, the celebrated actress, drew passionate condemnation from various corners.

\footnotetext{
${ }^{45}$ WCT, 30 August 1866, p.2.

${ }^{46}$ WCT, 29 August 1866, p.2; WCT, 29 August 1866, p.3.

47 Brookes, p.98.

${ }^{48}$ Lippert, p.328.

49 ibid; Alexander Bathgate, Colonial Experiences or Sketches of People and Places in the Province of Otago, New Zealand, (Glasgow: Maclehose and MacDougall Glasgow University Press, 1874), p.99; Gordon Ell, Gold Rush: Tales and Traditions of the New Zealand Gold Fields, (Auckland: Bush Press, 1995), p.68.

${ }^{50}$ William F. Heinz, Bright Fine Gold, (Wellington: Reed, 1974), p.183; Philip Ross May, Hokitika: Goldfields Capital, (Christchurch: Pegasus Press, 1964), p.37.
} 


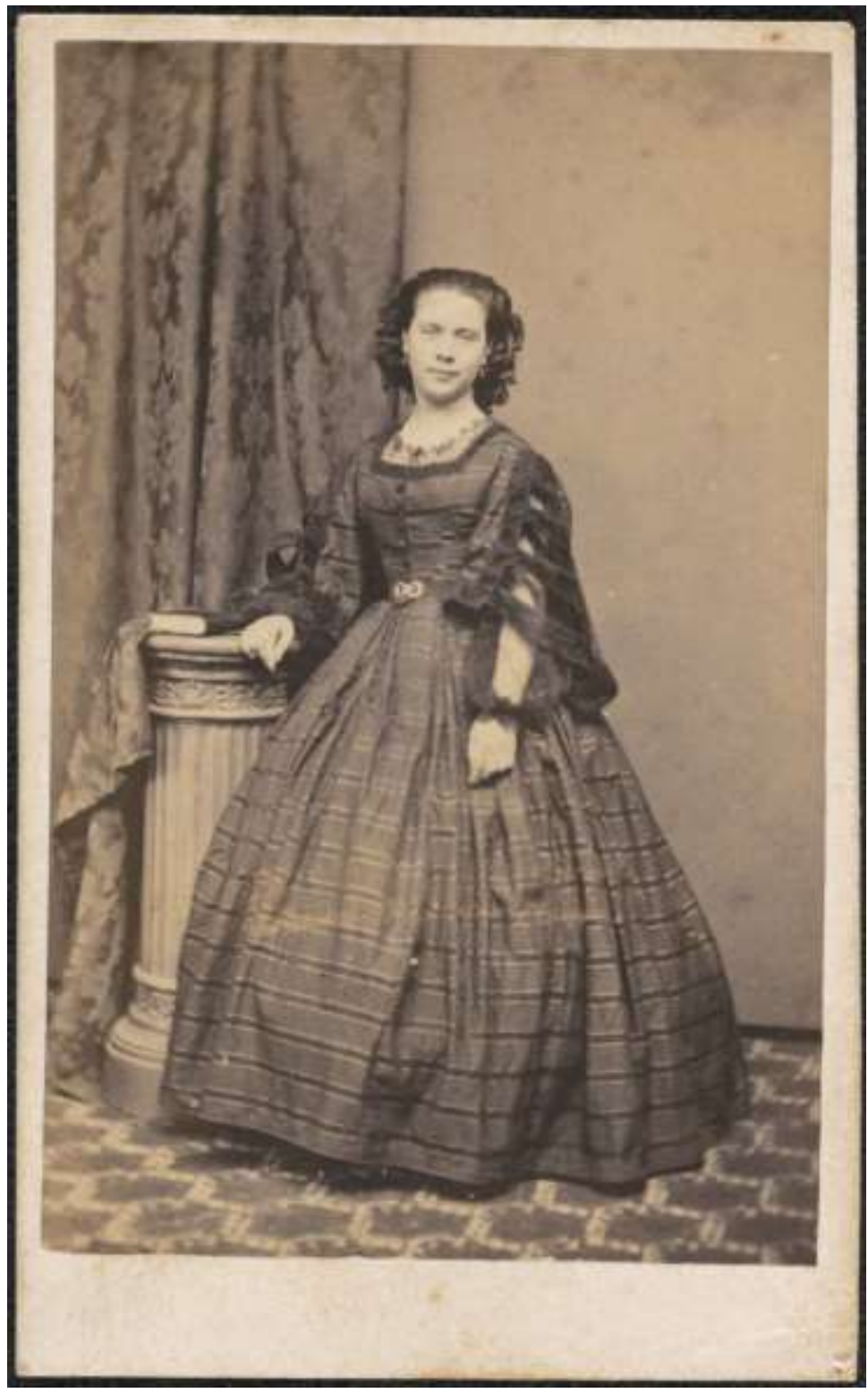

Figure 3.1: Julia Mathews in 1863

Source: 'Portrait of actress, Julia Mathews', 1863, Ref: PIC/15840,

National Library of Australia.

\section{Cross-Gender Performance}

The performance and production of amateur theatre by soldiers of the British army was a wellestablished tradition by the time the $58^{\text {th }}$ and $65^{\text {th }}$ regiments arrived in New Zealand in the midnineteenth century. Finding its genesis on British naval vessels, military dramatics began as exclusively male activities. Female roles were rendered by male members of the company and such performances, while comic, were not interpreted as affronts to the military performance of gender. Translating such practices to garrisoned settings, Alex Boutilier notes that, despite having access to capable female 
amateurs, garrisoned men in Halifax still 'found it necessary or even pragmatic, to act in women's roles. ${ }^{51}$ As the number of women performing, both professionally and as amateurs, increased throughout the nineteenth century, 'male domination of the theatre' slowly died out and women appeared more frequently on stage. ${ }^{52}$

Auckland's garrison theatre at Albert Barracks provided regular amusement for military and civilian playgoers during the late 1840 s and early 1850 s. The standard of entertainment was commendable on the whole, 'the only difficulty being', one playgoer recalled, 'that there were no ladies obtainable. ${ }^{53}$ Thus, the patron noted, 'the delineator of the blushing heroine was often some smoothfaced young fellow whose size and somewhat awkward gait caused hearty laughter. ${ }^{54}$ Cross-gender impersonations by military men were accepted garrison tradition and subsequently did little to degrade the masculinity of the performer. By the mid-1850s, an increase in the theatrical population in Auckland enabled garrison troupes to engage the services of amateur actresses - such as Emily Glyndon who became a regular feature of Auckland's garrison and civilian theatre - to fulfil female roles. ${ }^{55}$ In civilian settings, where female performers were comparatively abundant by the mid-nineteenth century, crossgender performance was almost entirely restricted, by theatrical convention, to genres such as burlesque and pantomime.

Less common than its male counterpart, cross-gender performance by women was viewed with greater suspicion by critics who interpreted the practice as a threat to masculine authority. Popular with writers and directors of comic genres, the interpretation and response to cross-gender performance by women in colonial theatre deserves some attention. Jacky Bratton suggests theatre women engaging in cross-gender performance were viewed as 'more transgressive' than their male counterparts because of the gendered hierarchy which existed outside the auditorium. ${ }^{56}$ Women, critics claimed, performed male roles for specific reasons and concern that this represented an attempt to renegotiate structures of interpersonal power saw the practice swiftly undercut with costume and conventions of display which exposed and re-sexualised the actress.

Powell argues that cross-gender performance was more readily accepted in genres which did not pose a threat to established social barriers. ${ }^{57}$ While serious impersonation was criticised for its defeminising, even dehumanising, effect, eroticised burlesques offered the safety of identifiable distinction between reality and performance. Cross-gender impersonations in burlesque and pantomime were established theatrical conventions and thus readily accepted by colonial audiences. ${ }^{58}$ Serious

\footnotetext{
${ }^{51}$ Boutilier, p. 107.

52 ibid, p. 108.

${ }^{53}$ An Old Hand, 'Memories of the Past, Auckland from 1847', in New Zealand Pamphlets Vol.21, Ref: AC911, AWMM, p.30.

54 ibid.

${ }^{55}$ DSC, 29 August 1856, p.2.

${ }^{56}$ Jacky Bratton, 'Mirroring Men: The Actress in Drag', in Maggie B. Gale and John Stokes (eds.), The

Cambridge Companion to the Actress, (Cambridge: Cambridge University Press, 2007), p.235.

${ }^{57}$ Powell, 'Gendering Victorian Theatre', p.357.

${ }^{58} O W, 1$ January 1864, p.3; GRA, 21 March 1867, p.2.
} 
impersonation received more mixed reviews, but some public and critical appreciation was expressed for women playing parts more traditionally reserved for men. Few female performers attracted more attention for their renditions of traditionally male roles than Amelia Poole who toured New Zealand with her husband Charles during the mid-1860s. As an actress of noted ability, Poole's reviews were generally positive. In instances where she tackled more serious male impersonations, however, critical commentary provides a useful insight into public expectations of female performers and the broader impact of gender inversion on stage.

Poole's first New Zealand appearance as Romeo in Hokitika in 1866 was widely commended. Opposite Rosa Cooper's 'wonderfully touching and effective' Juliet, 'Mrs Poole played Romeo', the West Coast Times reported, 'as only a true artist could have rendered it', and the pair received a 'well deserved ovation' from a sizeable audience. ${ }^{59}$ The Pooles departed for Dunedin after their Hokitika season, and in June 1866, having delighted audiences as Leah in popular sensation drama Leah the Forsaken, Amelia Poole announced her intention to appear as twin brothers Fabian and Louis de Franchi in Dion Boucicault's The Corsican Brothers. The announcement was met with interest, but the public needed some persuading. 'A lady's undertaking to play Louis and Fabian di Franchi is certainly a novelty that does not promise a very satisfactory result', the Otago Daily Times commented, but 'Mrs Poole really looked well as Fabian and played with considerable point and power. ${ }^{60}$ Poole's rendering of these roles to an acceptable standard was noted and the extent to which her ability as an actress protected her from public criticism is worth considering.

Following success as Romeo and the de Franchi brothers, Poole's performances became more transgressive. While continuing to intrigue the theatregoing public, some elicited a less favourable response from the press. In July 1866, theatregoers responded with 'considerable curiosity' when she appeared at the Princess Theatre as Hamlet. ${ }^{61}$ While not yet attempted in New Zealand, several women had played the Prince of Denmark during the late eighteenth and early nineteenth centuries with varying degrees of success.$^{62}$ Despite receiving three curtain calls, Poole's performance sat awkwardly with the press. This unease was articulated by the Otago Daily Times which noted that while the production overall had been 'most creditable', it was 'not possible to lose sight of the fact that the sorrows and the passions of a man [were] being uttered or depicted by a woman. ${ }^{63}$ An appearance as Othello received a similarly tepid response. Reviews noted that 'while the whole reading was marked by intelligence and great care...no actress should make the attempt to play such a character - that such an attempt never could be otherwise than unsatisfactory to an audience, and physically distressing to the attempter. ${ }^{94}$

\footnotetext{
${ }^{59}$ WCT, 3 May 1866, p.2.

${ }^{60}$ ODT, 26 June 1866, p.4.

${ }^{61} O D T, 2$ July 1866, p.4; ODT, 3 July 1866, p.4.

${ }^{62}$ Jill Edmonds, 'Princess Hamlet', in Vivien Gardner and Susan Rutherford (eds.), The New Woman and Her Sisters: Feminism and Theatre 1850-1914, (Ann Arbor: University of Michigan Press, 1992), pp.59-76.

${ }^{63}$ ODT, 3 July 1866, p.4.

${ }^{64}$ ODT, 21 August 1866, p.4.
} 
While some centred their criticism on the overall emotional complexity of the roles in question, others highlighted physical deficits. Correspondents for the Grey River Argus concluded that her Hamlet had been stunted by 'her physique not being equal to the part. ${ }^{95}$

Poole reprised both Hamlet and Othello in Christchurch later that year where she found, the Lyttelton Times reported, that the 'the public verdict was not in her favour.' ${ }^{66}$ An October performance of Hamlet at Christchurch's Theatre Royal drew particularly gendered criticism. 'There seems a sort of craze among the Australian actresses', the Press reviewer noted, 'to contrive a new sensation by departing from their natural roles and appearing in male characters. ${ }^{67}$ With women apparently both physically and emotionally incapable of rendering the nuance of serious male roles the practice, the critic argued, was a 'complete mistake':

In the first place, directly the disguised Hamlet steps forward on the stage, the voice and personal appearance, as well as every attitude and gesture, disclose the fact that the supposed prince is a woman in man's dress, at once exciting recollections of burlesque or extravaganza which jar awkwardly and even painfully with the solemnity of the scene and the familiar beauty of the poet's verse. Nor, supposing this difficulty is got over, is it ever likely that the conception or portrayal of the character will be a true one. It will be essentially feminine. Hamlet will be made to act, not as a real Hamlet would have done, but as a woman would act in the same circumstances - rightly enough perhaps for a woman, but in a man unnatural and absurd. Such was the case last night... The whole performance to any lover of Shakespeare, or to any one with a true idea of dramatic art, was a miserable affair. We shall be delighted to welcome Mrs Poole in any other (female) character, but we certainly hope... that we shall not be asked to see her a second time in Hamlet. ${ }^{68}$

Poole's reprise of Othello in early November was also greeted with suspicion and general lack of support from the press, epitomised by the Lyttelton Times' snide remark that the piece promised to satisfy 'those who [preferred] novelty to Shakespeare. ${ }^{69}$ The Press conceded, however, that while they retained their 'original objections to women appearing in male characters in anything but burlesque or extravaganza, and most of all in Shakespeare', Poole's Othello was 'infinitely superior' to her Hamlet. ${ }^{70}$

Analysis of Poole's varied reviews provides an insight into the gendered dynamics of theatrical performance in a colonial context. Theatrical convention enabled women to assume male roles in certain genres which already drew stark distinction between reality and the imagination of the stage. Burlesque and pantomime, for example, were deliberately outlandish and easily distinguished from reality. In serious dramas such distinction was not always so straightforward. Poole succeeded in treading this fine line with her performance in The Corsican Brothers, but melodrama already sat somewhere between respectable amusement and spectacle. Women appearing as men were typically promoted as novelty

\footnotetext{
${ }^{65}$ ODT, 3 July 1866, p.4; GRA, 17 July 1866, p.3.

${ }^{66}$ Lyttelton Times, 16 November 1866, p.5.

${ }^{67}$ Press (Christchurch), 23 October 1866, p.2.

${ }^{68}$ ibid.

${ }^{69}$ Lyttelton Times, 5 November 1866, p.2.

${ }^{70}$ Press (Christchurch), 6 November 1866, p.2.
} 
and critics baulked when such novelty was incorporated in the coveted works of Shakespeare. Even here, however, responses varied. The disparity in criticism received for Poole's performances of Hamlet and Othello, compared with her renditions of the lovesick Romeo, highlights the extent to which the position of characters along a scale of masculinity may have impacted public response.

Theatre, despite offering women greater opportunity for employment and freedom of expression than many other occupations, remained a predominantly male realm. While respected for their appropriately gendered performances, critics questioned the capability of female performers attempting to render more emotionally complex characters. In particularly esteemed roles, especially in tragedy and respectable drama, the perceived intricacy of male emotional experience was often emphasised in critical commentary. Lacking access to the full range of human emotion, the tragic anguish of the likes of Hamlet and other iconic characters of the legitimate stage, was, as the Press review indicates, deemed well beyond the reach of even the most talented female performer.

Accepted differences in the performance of gender between theatre and the world outside the auditorium largely protected female performers from gendered criticism. However, entertainments which consciously and actively transgressed gender norms within the theatre itself, such as Poole's Hamlet and Othello, did attract gendered criticism from the press. In Dunedin, while Poole received three curtain calls for her Hamlet, the Otago Daily Times restricted their praise to acknowledgement that the performance had been 'most creditable' quickly followed by an assertion that the emotional depth required by the character ensured that a female rendition 'could never be satisfactory' and would be necessarily marked by a "pervading sense of incongruity. ${ }^{71}$ The stage offered a liminal yet somewhat socially sanctioned space where gender could be inverted in the name of amusement, but discrepancy in critical and popular response demonstrates the continued ambiguity of female-male impersonation.

\section{Theatre Management}

The theatre business was marked by both opportunity and risk. While providing more artistic autonomy for theatre professionals than acting work, management came with its own challenges. Subject to the fickle swing of audience interest, theatres and those who worked within them, lived in a consistently precarious state. Playhouses relied on patronage, and their viability was significantly influenced by audience wants, fashions, and wider patterns of movement which created an unpredictable pool of theatregoers. In the gold towns, particularly, transient populations posed a threat to the financial stability of burgeoning professional amusement. For managers in these precarious settings, periods of success were shadowed by the ever-present threat of financial failure. ${ }^{72}$ Those who misread the appetite, or overestimated the size, of their prospective audience found the business unforgiving. Analysing the

\footnotetext{
${ }^{71}$ ODT, 3 July 1866, p.4.

72 Bernard Ince, 'Spectres of Debt in the Victorian Theatre: A Case Study of Management Failure', Nineteenth Century Theatre and Film, Vol.41, no.1, Summer 2014, pp.68-84.
} 
tenures of several colonial theatre managers provides an insight into the precarities and opportunities of theatre business in New Zealand.

\section{James Bartlett's Prince of Wales Opera House}

During the mid-1860s, the European population of the West Coast swelled by more than ten thousand, an influx unparalleled in New Zealand. ${ }^{73}$ The majority of Westland's early inhabitants were a highly transient population comprised of young, single men of diverse national origins. ${ }^{74}$ Attracted by mineral wealth in the rivers and beaches, the crowds swiftly transformed the tent settlement at Hokitika. Unlike San Francisco, Melbourne, and Dunedin which had expanded as a result of gold discoveries, the goldrush was entirely responsible for Hokitika's creation. ${ }^{75}$ By 1865 , land previously uninhabited by Europeans had been rapidly transformed into a lively centre where miners and those servicing the goldfields found gainful employment. Julius Haast described the transformation:

The principal street, half a mile long, consisted already of a large number of shops, hotels, banks and dwelling-houses, and appeared as a scene of almost indescribable bustle and activity. There were jewellers and watchmakers, physicians and barbers, hotels and billiard-rooms, eating and boarding-houses, and trades and professions of all description...Carts were unloading and loading, and sheep and cattle driven to the yards; there was shouting and bell-ringing, deafening to the passers-by; criers at every corner of the principal streets which were filled with people - a scene I had never before witnessed in New Zealand. ${ }^{76}$

It was into this hubbub that aspiring theatre manager James Bartlett arrived in November 1865. Bartlett was already acquainted with goldfield life. His early dramatic career had included appearances at the Theatre Royal in Ballarat and by 1863 he had established himself in Melbourne, touring Victorian gold towns as part of the Haymarket Theatre company. ${ }^{77}$ Bartlett soon moved up the theatrical ranks, appearing in Sydney in June 1864 as Acting Manager of the Prince of Wales Theatre. ${ }^{78}$ In January 1865, he married Maria Jane Moon, daughter of Sydney businessman Henry Moon. ${ }^{79}$

Bartlett's departure from Australia in October 1865 was colourfully described by the Sydney Punch as he left Port Jackson for the glitter and riches of the West Coast goldfields 'with six boxes, two carpet bags and a half, Shakespeare and Charles Mathews' works in the cabin, and a theatre and public house under each arm. ${ }^{80} \mathrm{He}$ planned to establish a professional theatre, complete with hotel and billiard rooms, to capitalise on the demand for amusement proffered by the inhabitants of Hokitika. ${ }^{81}$ Bartlett's

\footnotetext{
${ }^{73}$ Murray McCaskill, 'The Gold Rush Population of Westland', New Zealand Geographer, Vol.12, no.1, April 1956, p.32.

74 ibid.

${ }^{75}$ May, Hokitika, p.12.

${ }^{76}$ Julius Haast quoted in May, Hokitika, p.12.

77 Star (Ballarat), 3 March 1862, p.3; Bendigo Advertiser, 20 March 1863, p.2.

${ }^{78}$ Empire (Sydney), 18 February 1864, p.5.

${ }^{79}$ Sydney Morning Herald, 21 January 1865, p.1.

${ }^{80}$ Sydney Punch, 2 October 1865, p.8.

${ }^{81}$ WCT, 26 October 1865, p.2.
} 
progress was closely monitored by the press. Reports that components of a pre-constructed theatre building 'capable of holding 1400 people' had shipped from Sydney sparked particular excitement. ${ }^{82}$ The plans were ambitious, not only was the theatre designed to seat almost a fifth of the town's population, it was to include gas lighting - a first on the West Coast - and other modern improvements necessary to 'induce patronage' and 'provide for the comfort of visitors. ${ }^{83}$

Soon, however, difficulties arose, beginning with dispute over the purchase of a site on Revell Street. ${ }^{84}$ Shortly thereafter, Bartlett's partnership with his Acting Manager William Dind dissolved and his New Year's Day opening was delayed indefinitely. ${ }^{85}$ On 5 January 1866, he began advertising the construction of a new theatre building, this time funded by his father-in-law in Sydney. ${ }^{86}$ By February, work on Hokitika's new 'architectural feature' of 'very conspicuous proportions', was under way. ${ }^{87}$ Architect C. G. Smith had designed eighteen theatres throughout the colonies and the United States. The Hokitika theatre measured 150 feet by 42 feet, with a front elevation 35 feet high and entryways 'wide enough in plenty' for 'expansive crinolines. ${ }^{88}$ Tackling the elements with a wooden ceiling lined 'to deaden the rattle of the rain on the roof' and a veranda 10 feet deep, the establishment was complete with café, billiard saloon, and ladies' refreshment and cloak rooms.

The Prince of Wales Opera House opened to audiences on 19 March 1866 with the arrival of the Lenton Troupe, who were completing their tour of New Zealand before departing for India. Ticket prices ranged from $2 \mathrm{~s}$ for the pit to $£ 3-3-0$ for private boxes seating a party of six. ${ }^{89}$ The first engagement was a success and, commenting on a benefit held by the Troupe in Bartlett's honour at the end of March, the editors of the West Coast Times expressed their hope that the public would 'testify their full appreciation' for Bartlett's enterprise in having the gall to undertake 'the most spirited and costly theatrical experiment yet attempted in Westland. ${ }^{90}$

The dramatic season opened on 27 March 1866 with comic sketch $L M N O P Q$ starring Rosa Cooper and Lionel Harding. The next month of performances were largely comedic, beginning with a triple-bill on 11 April comprising Tom Taylor's farce A Blighted Being, John Maddox's comic drama A Curious Case, and Frank Talfourd's domestic sketch The Household Fairy. Early responses were overwhelmingly positive. Subsequent programmes grew more ambitious, incorporating the likes of Boucicault's The Corsican Brothers and Shakespeare's Richard III. Having introduced legitimate drama to the West Coast, Bartlett's service in placing 'on the stage many of the best and most popular of the dramas and comedies of the British stage' was much applauded. ${ }^{91}$ The speed with which the

\footnotetext{
${ }^{82}$ WCT, 14 November 1865, p. 3 .

${ }^{83}$ WCT, 10 February 1866, p.3.

${ }^{84} W C T, 23$ December 1865, p.3.

${ }^{85}$ WCT, 19 December 1865, p.3.

${ }^{86}$ WCT, 5 January 1866, p.1.

${ }^{87}$ WCT, 10 February 1866, p.3.

88 ibid.

${ }^{89}$ WCT, 2 March 1866, p.3.

${ }^{90}$ WCT, 31 March 1866, p.2.

${ }^{91}$ WCT, 12 May 1866, p.6.
} 
company delivered new pieces was also acknowledged, with one critic suggesting that 'in no house in any colony or at home, [had] a rapid succession of pieces been ever produced with greater smoothness and effect. ${ }^{92}$

Analysis of attendance reveals the general success of Bartlett's first dramatic season. In the absence of any record of ticket sales, estimates of audience size can be made using qualitative reports in the press. House size, ranked on a 9-point scale and charted across time, highlights fluctuations in attendance over the duration of the season. The press did not always comment on audience size. When they did, however, consistent phrases were used which allow the qualitative data to be operationalised, roughly, with a numeric scale ranging from 1 (very bad) to 9 (full):

$\mathbf{1}=$ Very bad

$\mathbf{2}=$ Poor or 'very thin'

$\mathbf{3}=$ Small or 'thin'

$\mathbf{4}=$ Very moderate or 'tolerable'

5 = Moderate

$\mathbf{6}=$ Fair or 'moderately good'

$7=$ Good

$\mathbf{8}=$ Very good or 'well-filled'

$\mathbf{9}=$ Full, 'crowded' or 'capital'

Structuring the data as such enables it to be charted and analysed to identify factors which influenced attendance. Benefit performances, engagements of new actors, and 'other' variables such as weather, all impacted theatre attendance. While imperfect, analyses conducted in this manner provide an insight into audience size and composition, which regularly eludes historical analysis.

Bartlett's diverse programme of acrobatics, light farce, and legitimate tragedy attracted several full houses (figure 3.2). Benefit performances, and patronage from local organisations boosted audience numbers on several occasions and, while the company of actors assembled by the enterprising manager did not satisfy all critics, they were generally applauded for their efforts. Poor weather detrimentally impacted some houses. For the most part, however, the press applauded the number of hardy theatregoers who assembled regardless of regularly inclement weather and even, on 4 June 1866, despite the 'pouring rain and heavy storm. ${ }^{93}$

\footnotetext{
92 ibid.

${ }^{93}$ WCT, 5 June 1866, p.2.
} 


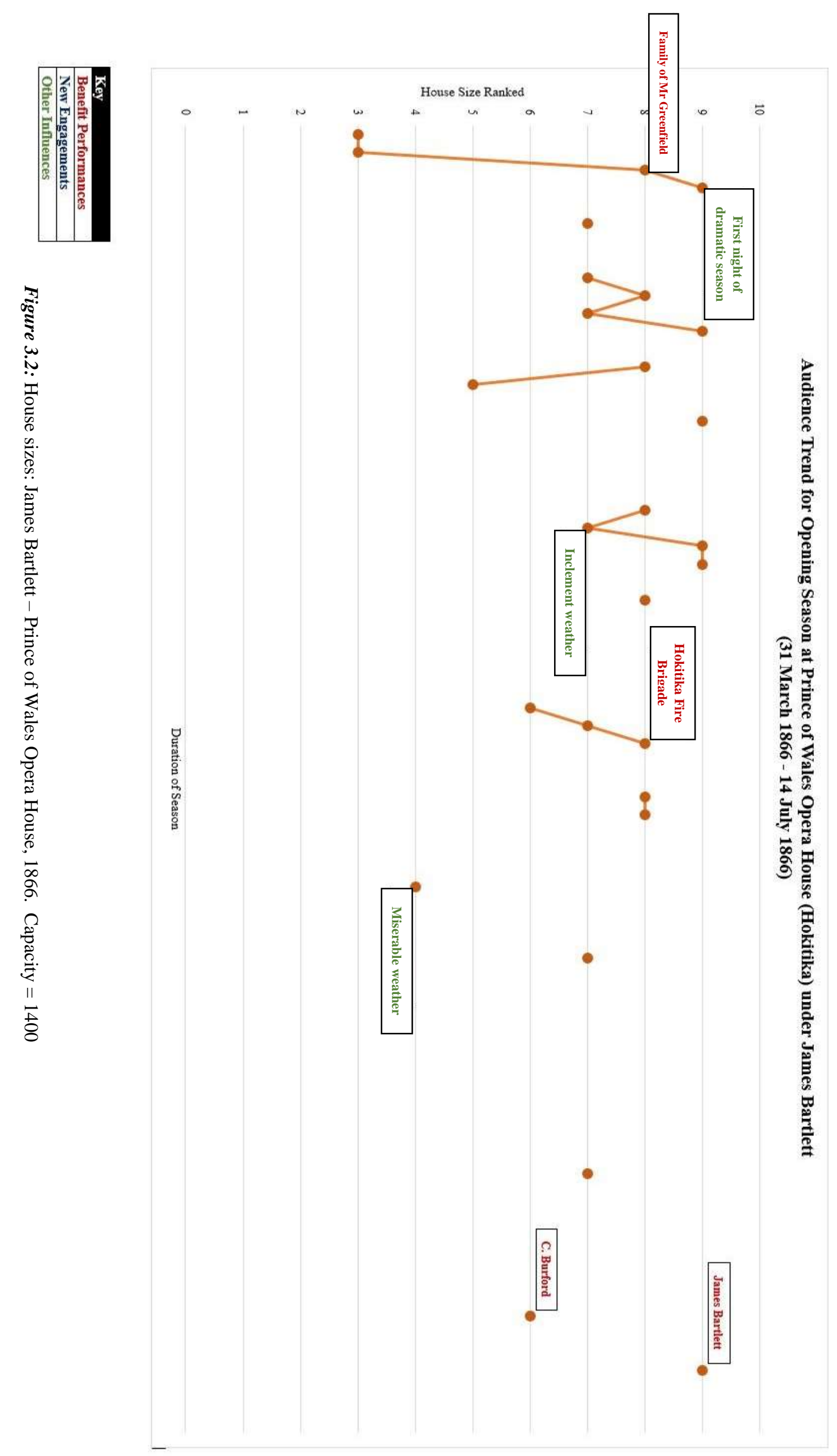


Gold-driven migration, which facilitated Hokitika's rise to national prominence, also brought about its decline. As the rushes abated between 1867 and 1868, Bartlett's constituency of theatregoers rapidly diminished. ${ }^{94}$ The departure of many miners for goldfields further north had a significant impact on the demand for entertainment in Hokitika. In 1866, the Prince of Wales company had performed 91 different pieces. Performances dropped rapidly over the next two years until 1869 when just 30 performances were staged. Seeking to diversify, Bartlett assumed the management of Hokitika's City Theatre, and advertised it for lease for public lectures and balls. ${ }^{95}$ By August 1867, however, audiences were drying up. The press reported that the town had been 'very dull' and while the theatres were open, they only occasionally received good houses. ${ }^{96}$ Signs of trouble continued the following year as the string of poor audiences threatened the viability of the Prince of Wales. Having experienced 'checkered fortunes' for some months, there was speculation that the Opera House would close its doors entirely. ${ }^{97}$ It was hoped that the smaller City Theatre would be able to attract audiences large enough to sustain itself. The Prince of Wales did, however, survive with the timely arrival of Fanny and Martin Simonsen and their opera troupe.

Rebranded the Duke of Edinburgh Theatre following a spell of Fenian agitation and an assassination attempt against the Queen's eldest son in early 1868, the establishment began to rely heavily upon performances by visiting touring groups. ${ }^{98}$ The West Coast Times detailed the state of affairs:

We had two theatres, and we have now only one. The Prince of Wales Opera House, recently christened the Duke of Edinburgh Theatre, is a fine commodious building, perfect in all its appliances; but the speculation of its spirited proprietor has not proved a success. No doubt it is Mr Bartlett's destiny to achieve greater fortune as an actor than as a theatre proprietor. A speculation upon the large scale attempted in the Prince of Wales was necessarily a very doubtful one. ${ }^{99}$

Despite a successful season by Mr and Mrs J. L. Hall, and a benefit performance for Bartlett which drew a house crowded with 'all the elite of the town', legal difficulties with business partner L. E. Threlkeld - to whom Henry Moon had sold his share in 1866 - compounded Bartlett's woes. ${ }^{100}$ By early July 1868, both the Duke of Edinburgh and the Princess Theatre (formerly the City) had closed temporarily, with the West Coast Times concluding that Bartlett's enterprise had been 'on too large a scale for the requirements of the town. ${ }^{101}$ Bartlett had given Hokitika residents access to both legitimate drama and more contemporary sensation pieces popular with British and Irish audiences. Despite engaging many stars of the colonial stage, the scale of his investment had exceeded the capacity of his

\footnotetext{
${ }^{94}$ McCaskill, p.49.

${ }^{95}$ WCT, 8 October 1867, p.3.

${ }^{96}$ WCT, 2 August 1867, p.5.

${ }^{97}$ WCT, 2 March 1868, p.5.

${ }^{98}$ WCT, 2 April 1868, p.6.

${ }^{99}$ WCT, 29 April 1868, p.5.

${ }^{100}$ WCT, 30 May 1868, p.6; WCT, 1 July 1868, p.6.

${ }^{101}$ WCT, 1 July 1868 , p.6.
} 
constituency of theatregoers. While the venture received considerable support early on, the transient goldfield population could not sustain an entertainment venue this large. Bartlett remained in Hokitika until April 1869 when, following a final season of comedic and predominantly Irish works, his house and some personal effects were sold at public auction. ${ }^{102}$

\section{Debt and Tom Fawcett's Theatre Royal}

Operating in a volatile commercial environment demanding constant novelty, debt was a common bane for colonial theatre managers. The threat of insolvency was particularly pressing for those who founded ventures in goldrush settlements fluctuating between boom and bust. Being largely amateur, military performers had few financial liabilities and were not accountable to external creditors. In gold town locations, however, the constant ebb and flow of income coupled with the glittering prospect of success lead several professional performers and managers into financial strife

The passage of the New Zealand Debtors and Creditors Act in 1862 allowed all debtors to petition for release from jail and discharge of debts in exchange for an assignment of assets proving they were unable to pay their liabilities in full. ${ }^{103}$ In cases where theatre practitioners and managers were forced to file for insolvency, these assignments offer a unique insight into the "exigencies of jobbing performers' operating in a colonial context. ${ }^{104}$ Examination of a series of debtors petitions filed by members of the theatrical profession during the 1860 s demonstrates the significant economic precarity of this brand of employment, and highlights the various costs involved in producing and promoting professional entertainment in colonial New Zealand.

The debtors petition of Tom Fawcett (known offstage as Thomas Wright Rowe) is among the insolvency claims filed between 1864 and 1866 examined. ${ }^{105}$ Fawcett first fell into financial difficulty in early 1864 when his venture in Queenstown, for which he had secured the professional services of several Dunedin stars, collapsed. By 1863, across Otago, more than eleven settlements supplied the goldfields. Among them, Clyde and Alexandra serviced Dunstan miners, and Roxburgh and Lawrence served diggers at Teviot and Tuapeka. Following gold discoveries along the Arrow and Shotover Rivers in 1862 which precipitated a secondary rush from the earlier diggings, Queenstown cemented itself as a significant inland supply town (figure 3.3). Government officials noted the remarkable growth of the lakeshore settlement in a report presented to the House of Representatives in 1863 commenting on the expansion of this now 'large and important township. ${ }^{106}$ Land which, just seven months earlier, had housed a 'solitary homestead' was now 'the abode of a busy and energetic population. ${ }^{107}$

\footnotetext{
102 WCT, 12 April 1869, p.3.

${ }^{103}$ Peter J. Coleman, A Blot in the Statute Book: Imprisonment for Debt in New Zealand 1840-1990,

(Wellington: NZHistoryJock, 2016), p.79; Debtors and Creditors Act, 1862.

${ }^{104}$ Davis, Economics of the British Stage, p.197.

105 'ROWE, Thomas Wright - Dunedin - Comedian', 1864, Dunedin Debtors Petition Files, Ref: R19952576,

Dunedin, Archives New Zealand (ANZ), Schedule B.

106 'Report on the Otago Gold Fields', AJHR, 1863, Session I, D-06, p.12.

107 ibid.
} 


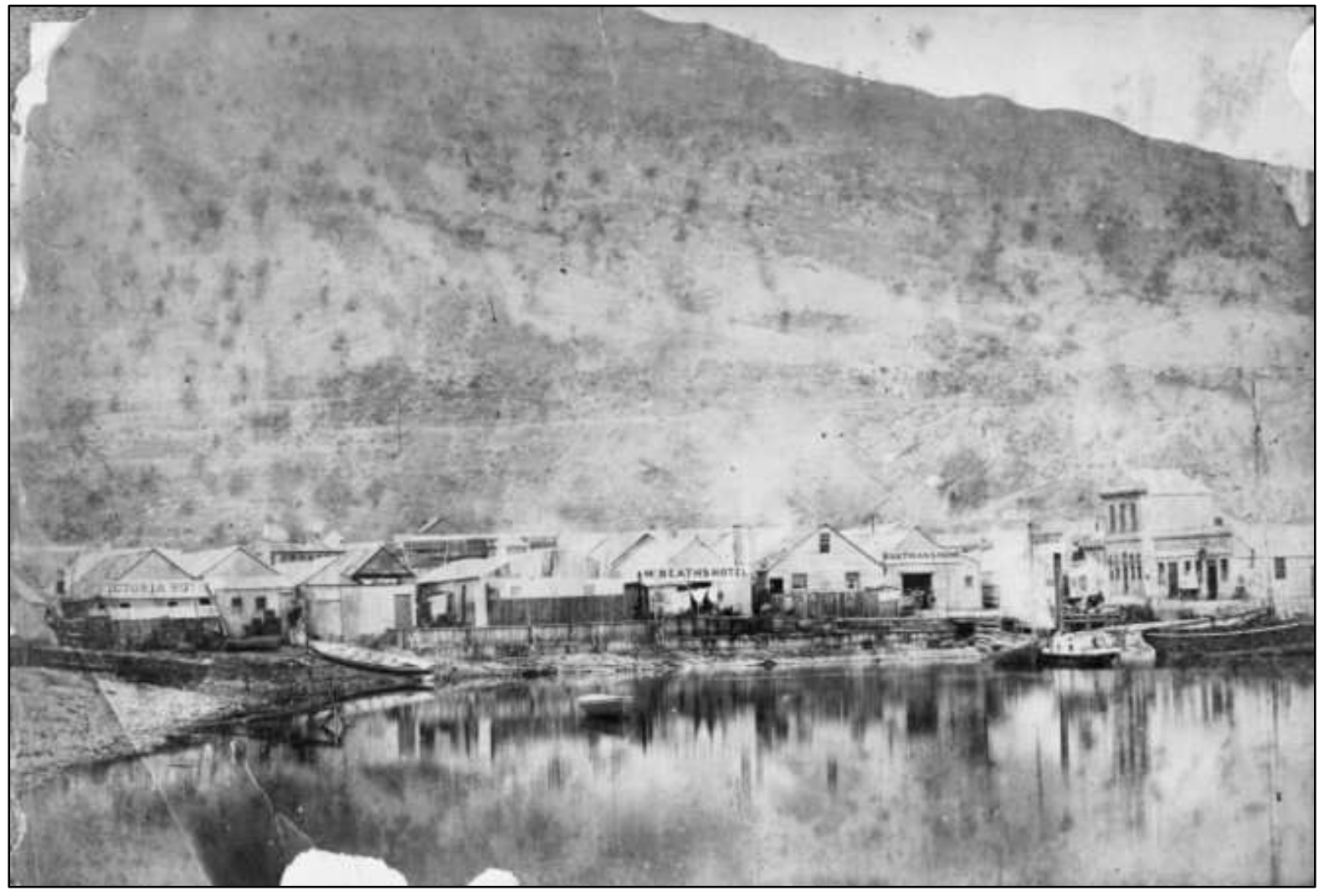

Figure 3.3: Queenstown c.1860s.

Source: 'Queenstown', ca 1860s, Ref: 1/2-049217-F, Alexander Turnbull Library.

Travelling musical satirists Charles Thatcher and Madame Vitelli had stopped briefly in Queenstown in May but since then entertainment had been slim. On 15 August 1863, an advertisement for a theatrical performance by a troupe of actors who had previously entertained audiences in Melbourne and Dunedin appeared in the recently established Lake Wakatip Mail. Fawcett, and other professionals, had just completed an extensive tour of the Otago diggings and, in September, the opening of the Theatre Royal marked the beginning of Queenstown's first, albeit short-lived, professional theatre. Seeking to provide Queenstown theatregoers with 'a class of entertainment worthy of their patronage', Fawcett introduced a season ticket scheme 'somewhat novel on the goldfields' which enabled him to engage the services of several performers from Dunedin's Princess Theatre. ${ }^{108}$

The resulting company had experience performing for goldfield audiences. Among them was Emma St Clair, who had enjoyed success in Bendigo, Ballarat, and Dunolly during the 1850s. ${ }^{109}$ Kate Grant, W.G. Carey, Tom's future wife Eliza Royal, and his brother Sandford completed the company. ${ }^{110}$ A comedic bill comprising the comedietta Delicate Ground and popular farces The Rough Diamond

\footnotetext{
${ }^{108}$ LWM, 23 September 1863, pp.4-5.

${ }^{109}$ Bendigo Advertiser, 15 August 1867, p.3; Maryborough and Dunolly Advertiser, 23 October 1857, p.1; Star (Ballarat), 7 December 1857, p.3.

${ }^{110}$ LWM, 26 September 1863, p.4.
} 
and The Spectre Bridegroom opened the season on 26 September $1863 .{ }^{111}$ Fawcett's comic selections were supported by the press who declared that the manager had 'shown commendable discrimination' in constructing his programme. 'Though such trifles are scarcely calculated to show his company off to any great advantage', the paper noted, 'yet the gratification of the audience will surely be better attained by a side-splitting farce or sparkling comedy, than by condemning them to yawn through some lumbering five-act tragedy or drama.' ${ }^{112}$

Early signs looked promising. Opening night attracted a house 'crowded to suffocation' but 'determined to appreciate the beauties, and overlook the defects of the entertainment', and crowded houses continued throughout October, with audiences clambering to witness performances deemed 'not unworthy of Dunedin. ${ }^{113}$ In November, Rob Roy and Cinderella were well received, and recent arrival Robert Baldwin Dale drew much praise for his rendition of Bob Ticket in The Alarming Sacrifice which would have 'done credit to Buckstone himself.' 114 A friendly competition between Carey, Dale, and Fawcett saw three renditions of Othello later in the month, with each taking turns at the leading role. ${ }^{115}$ The year concluded with The Corsican Brothers, the mechanical effects of which 'exceeded expectations' as critics noted it had been 'seldom...better performed - and never on an up-country stage.' 116

With early success, the company soon faced competition for audiences. In late October, a group of shareholders invested in Thomas Steward's proposal to construct a large wooden theatre on Ballarat Street and in mid-November, Henri Barnet, formerly of the Prince of Wales Theatre in Melbourne, announced the opening of an establishment under the same name at the Boatman's Arms on Beach Street. ${ }^{117}$ It was not, however, until late December that the first real sign of difficulty emerged when the following appeared in the Lake Wakatip Mail:

We may remark en passant, that Mr Fawcett has striven hard for the amusement of the Queenstown public since his arrival here, and many may thank him for rendering the evenings less dreary and tedious than they were wont to be, and for whiling away many an hour of ennui or fatigue. He has done his best, and we are sorry to see his exertions so scantily appreciated and repaid as they should be. As the only really legitimate place of amusement in Queenstown, the theatre deserves to be more widely patronised. ${ }^{118}$

The call was answered, and the ensuing pantomime, Bombastes Furioso, was well patronised. Shortly afterwards, however, a disagreement between Fawcett and the proprietor of the Royal Hotel forced the company to move to Barnet's Prince of Wales Theatre. ${ }^{119}$ Through January 1864 the transient nature of

\footnotetext{
111 ibid, p.5.

112 ibid, p.4.

${ }^{113}$ LWM, 30 September 1863, p.4; LWM, 7 October 1863, p.4; LWM, 17 October 1863, p.4.

${ }^{114} L W M, 11$ November 1863, p.4.

${ }^{115}$ LWM, 25 November 1863, p.4.

${ }^{116}$ LWM, 26 December 1863, p.4; Flanders, pp.333-335.

${ }^{117}$ LWM, 21 October 1863, p.4; LWM, 14 November 1863, p.5.

${ }^{118}$ LWM, 26 December 1863, p.4.

${ }^{119}$ LWM, 30 December 1863, p.4.
} 
the wider population continued to threaten business and the constituency of theatregoers ultimately proved 'hardly large enough' to sustain a professional dramatic company even with the occasional 'influx of miners' which could 'by no means be depended upon.' ${ }^{120}$ In mid-February, the company abruptly departed for Invercargill in the hopes of repairing their fortunes.

At the end of April, Fawcett sought protection under the Debtors and Creditors Act (1862) when he filed for insolvency in Dunedin citing debts amounting to £313-15-0. Fawcett attested that his debts stemmed, largely, from the lack of patronage in Queenstown, which had failed to cover personal costs for board and lodging and professional expenses for drapery and ironwork. He was also liable to creditors in Dunedin, owing a printing and advertising debt of $£ 6$ to Messrs Mills, Dick and Co of Stafford Street, and $£ 60$ to Shadrach Jones, Fawcett's principal creditor, for cash loans received between 1862 and $1863 .^{121}$

The sudden boom and bust of the Queenstown Theatre Royal highlights the precarities of theatrical employment in a goldrush town. The constituency of theatregoers was incredibly mercurial and entertainers, much like other services, were susceptible to wider changes in population precipitated by the success, or otherwise, of nearby diggings. In 1863, the population of the Wakatipu goldfields was estimated at just over 7,000 (with 2,000 engaged in trade or other auxiliary occupations). ${ }^{122}$ While the goldfield was rich, the population was widely dispersed and transport routes to larger supply towns were hazardous, and often flooded. Entertainment was in high demand, but the stability and accessibility of the theatregoing population could not support a permanent professional company. Touring proved the better option, giving performers access to the transient mining populations without the inherent risks involved in significant capital investment.

Goldfield managers like Fawcett and Bartlett were not the only ones to encounter financial strife. Others faced equally trying circumstances in Dunedin. Underscoring the significance of the business relationship between press and playhouse, advertising was a particularly common source of debt. Stuart O'Brien, who took over as manager of the Princess Theatre in April 1866, amassed advertising debts of $£ 72-11-0$ by the time he filed for insolvency five months later. ${ }^{123}$ The majority of O'Brien's deficit, some $£ 47$, was owed to the proprietors of the Otago Daily Times but he also owed fees to W.J. Henningham of the smaller Evening Star (£7-19-0), William Besemeres of the News Letter (£1-0-0), and to Mills, Dick and Co for the printing of playbills and posters (£16-1-6). Sandy Greig, the theatre billsticker, also claimed his salary of $£ 2-10-0 .{ }^{124}$

\footnotetext{
${ }^{120} O D T, 6$ February 1864, p.5.

121 'ROWE, Thomas Wright - Dunedin - Comedian', 1864, Dunedin Debtors Petition Files, Ref: R19952576,

Dunedin, ANZ, Schedule B. Jones invested significant capital in developing the entertainment scene in Dunedin. Ultimately, however, he too filed for insolvency in 1864.

122 'Report on the Otago Gold Fields', AJHR, 1863, Session I, D-06, p.19.

123 'O’BRIEN, Francis Stuart - Dunedin - Comedian', 1866, Dunedin Debtors Petition Files, Ref: R19952974, Dunedin, ANZ, Schedule B.

124 ibid.
} 
Close examination of O'Brien's insolvency petition provides an insight into theatre business expenditure in colonial New Zealand. By the time he appeared before the Resident Magistrate following his tenure at the Princess Theatre, O'Brien owed fees to two of Dunedin's music sellers - George Richard West (£5) and W.C. Begg (16s) - for their services and the hire of a piano. He also owed hairdresser Davis £1-4-0 for wigs, £22-1-0 to gas engineer Stephen Hutchinson, and £40 to comedian George Coppin for dues to the Dramatic Authors' Fund (a form of copyright protection for playwrights) which were paid on an annual basis. ${ }^{125}$ Highlighting the diversity of O'Brien's workforce and providing a valuable insight into the daily workings of the theatre as a place of business, several employees came forward with salary claims amounting to £164-16-6. As manager and lessee, O’Brien was personally liable to cover the wages of his staff alongside the maintenance of his own wardrobe and the venue itself. Actors' stock of personal effects, including costumes, remained their own property. O'Brien was forced to declare his own professional wardrobe as an asset valued at $£ 50 .{ }^{126}$ During the 1866 season, he maintained a stock company of eleven to support star engagements Charles and Amelia Poole, contracted for £23-15-0. Other salaried employees included Achille Henry (musician), H.J. Willis (scenic artist), S. Greig (billsticker), F. Woods (painter), R.H. Fox and William Morris (cheque takers), Frank Carr (money taker), F. Fuiner (waiter), and ushers Edward Feely and J. James. ${ }^{127}$

O'Brien was not the only manager to face difficulties. In March 1866, William Henry Mumford had also filed for insolvency, citing 'heavy liabilities' incurred introducing professional talent to Dunedin leaving debts of $£ 636-2-0 .{ }^{128}$ Nearly a sixth of his total debts, $£ 101-15-0$, were owed to the Otago Daily Times. Despite clear deficiencies in fiscal management, Mumford attributed a sizeable portion of his deficit to a professional excursion to Christchurch which had fallen flat when 'three months of uncertain weather,' generated a falling off in receipts. His hot temper had also forced him into several sticky situations, however, evidenced by more than $£ 50$ owing to barristers and solicitors. A particularly well publicised confrontation with his business partner George Donne in 1865 resulted in an appearance before the Resident Magistrate when the heated exchange concluded with Mumford 'presenting a loaded pistol' at his companion's head. ${ }^{129}$

While their capital investment made them particularly vulnerable, managers were not the only theatre practitioners to struggle financially. ${ }^{130}$ Scenic artist John Stanley Willis filed for insolvency in 1866 with debts of more than $£ 130$ following the dissolution of his business partnership. ${ }^{131}$ Singular misfortunes could also wreak havoc. Robert Baldwin Dale, for example, watched his entire theatrical

\footnotetext{
125 'The Dramatic Author's Society', Herald (Melbourne), 19 September 1868, p.3.

126 'O’BRIEN, Francis Stuart', 1866, Dunedin Debtors Petition Files, Ref: R19952974, Dunedin, ANZ,

Schedule C.

127 ibid, Schedule B.

128 'MUNFORD', William Henry - Dunedin - Theatre Manager', 1866, Dunedin Debtors Petition Files, Ref: R19952920, Dunedin, ANZ, Schedule B.

${ }^{129}$ ODT, 6 September 1865, p.5.

${ }^{130}$ Davis, Economics of the British Stage, p.197.

131 'WILLIS, John Stanley - Dunedin - Scenic Artist', 1866, Dunedin Debtors Petition Files, Ref: R19952978, Dunedin, ANZ.
} 
wardrobe go up in smoke when his hotel burnt down in 1864, and jobbing actor William Ryan found his inconsistent income insufficient to cover unexpected costs, citing 'want of employment [and] sickness in family' when he filed for insolvency in 1866. ${ }^{132}$ Analysis of debts and business failure provides a crucial insight into the risks and precarity of theatre work during the nineteenth century. Theatre managers were public figures and their job was both diverse and time-consuming. In addition to organising and directing rehearsals, managers negotiated contracts with actors and other personnel, selected programmes, supervised all production details, and liaised with printers and newspaper editors. ${ }^{133}$ Each aspect introduced costs which could easily build up if the manager's programme did not attract audiences large enough to cover their expenses.

\section{Female Managers}

Despite the added risks, women also worked in the business side of theatre. Between 1830 and 1914, Tracy Davis estimates that more than 330 women occupied theatre management positions in Britain. ${ }^{134}$ Regardless of how they came to occupy those roles, these women challenged conventional constructions of femininity. ${ }^{135}$ The pliability of theatre work enabled both men and women to advance from stage to management with comparative ease. However, Jo Robinson argues that the transition from the 'feminine' work of actress to the 'masculine' role of manager, 'had the potential to shake up existing theatrical and commercial practices. ${ }^{136}$ Examining female theatre managers in colonial New Zealand, the remainder of this chapter assesses the extent to which their experience resembled that of their male counterparts and how their assumption and performance of management responsibilities was shaped by general impressions of theatre as a viable occupation for women.

In the United States, the 'determined women' who took on management roles which challenged 'evolving standards of proper and acceptable work for women' caused headaches for those seeking to define the 'proper' role of women in nineteenth-century North America. ${ }^{137}$ Women were able to work in theatre management, Jane Curry argues, because the industry as a whole 'lived and worked somewhat outside the boundaries of respectable society' and consequently had 'greater flexibility in defining women's work.' ${ }^{138}$ As evidenced by the challenges facing female actors, entry into the theatrical

\footnotetext{
132 'DALE, Robert Baldwin - Comedian - Dunedin', 1864, Dunedin Debtors Petition Files, Ref: R19952689, ANZ, Dunedin Regional Office; 'RYAN, William - Dunedin - Comedian', 1866, Dunedin Debtors Petition Files, Ref: R19952985, Dunedin, ANZ.

${ }^{133}$ Jane Kathleen Curry, Nineteenth-Century American Women Theatre Managers, (London: Greenwood Press, 1994), p.1.

${ }^{134}$ Tracy C. Davis, 'Female Managers, Lessees and Proprietors of the British Stage (to 1914)', Nineteenth Century Theatre and Film, Vol.28, no.2, December 2000, pp.115-144.

${ }^{135}$ Gardner, 'Introduction', p.10; Jo Robinson, 'The Actress as Manager', in Maggie B. Gale and John Stokes (eds.), The Cambridge Companion to the Actress, (Cambridge: Cambridge University Press, 2007), p.158.

${ }^{136}$ Robinson, p. 158 .

${ }^{137}$ Curry, p.1.

138 ibid, p.4.
} 
profession was, in itself, a direct affront to Victorian middle-class respectability. ${ }^{139}$ Having already challenged the foundation of social respectability, theatre women, Curry notes, 'were probably less likely to have their managerial ambitions checked by social pressure' and female managers went largely unquestioned, particularly in provincial playhouses. ${ }^{140}$

Catherine Bishop's study of colonial businesswomen in New Zealand devotes some attention to those whose business she describes as 'the antithesis of modest colonial femininity.' ${ }^{141}$ Examining women who spent their working lives pushing gendered expectations - a small section addresses those who made their living in the burgeoning theatre industry. ${ }^{142}$ These performers were 'truly transgressive', Bishop argues, and challenged ideals of 'proper' womanhood by making their living 'boldly demanding attention for their talent...and, perhaps even more boldly, demanding payment. ${ }^{143}$ Discussing Mrs W.H. Foley (Catherine Huggins) who founded Auckland's Theatre Royal with her husband in the mid1850 s before touring the colony with great success during the 1860s, Bishop alludes to a lively female presence in theatrical management. ${ }^{144}$ Foley's adulterous affairs and exotic globe-trotting, however, paint her more as an exuberant outlier than as part of a wider pattern of female theatre management. At Dunedin's Princess Theatre, four different women served as director between 1865 and 1867, and Mrs J.M. Wolfe was sole lessee for five months from February to July 1865 following her husband's death. All four directors were so-called 'actress-managers', women who progressed to management through careers as successful performers. ${ }^{145}$ The following will examine the processes by which these women came to occupy management roles and the degree of success they enjoyed, measured by house size and critical response from the press.

The first woman to take the helm was Rosa Cooper. Having toured extensively in Victoria, Cooper was already popular with colonial audiences when she arrived in Dunedin on 23 December 1864. 'Report speaks highly of this lady's performances in Melbourne', the Otago Daily Times noted, and the correspondent felt confident that Cooper would be equally successful in creating 'a favourable impression' with the theatregoing population of goldrush Otago. ${ }^{146}$ Engaged by Joseph Wolfe, who had also found fame on the Victorian goldfields, Cooper made her first appearance on 26 December, as Helen Macgregor in an adaptation of Walter Scott's Rob Roy before a 'capital house...in high Boxing Night temper. ${ }^{147}$ Success continued throughout her first month and she sustained various lead roles opposite the current leading man of the company, P.C. Cunningham.

\footnotetext{
${ }^{139}$ Davis, Actresses as Working Women, pp.69-78.

${ }^{140}$ Curry, p.5; Davis, 'Female Managers', pp.115-144.

${ }^{141}$ Bishop, p.261.

142 ibid, pp.261-268.

143 ibid, p. 262.

144 ibid, pp.264-266.

${ }^{145}$ Robinson, pp.157-172.

146 ODT, 24 December 1864, p.4.

147 ODT, 27 December 1864, p.4.
} 
In late February 1865, Wolfe, a popular favourite since his arrival in 1862, fell severely ill. ${ }^{148}$ With the manager incapacitated, direction of the rapidly approaching autumn season fell to Cooper who accepted the position, 'with a view to the benefit of [Wolfe's] family and wife.' ${ }^{149}$ The season opened on Saturday 25 February 1865 with John Baldwin Buckstone's The Wreck Ashore and William Brough's Conrad and Medora. Addressing the audience during the interval, Cooper appealed to Dunedin's theatregoers for their support in ensuring a successful season. ${ }^{150}$ 'When one who has striven earnestly and well to give to the public a high class of theatrical entertainment is so deeply and affectingly concerned', the Otago Daily Times added in support of Cooper's plea, 'the circumstances should assuredly operate to make the season a successful one.' ${ }^{151}$ The Monday following the opening performances, however, Wolfe died and the Princess Theatre moved, for the first time, under the lessee and directorship of two women - his wife and Rosa Cooper. ${ }^{152}$

In her extensive analysis of the British stage, Davis argues that 'family-firm' structures of management often significantly benefited women. ${ }^{153}$ Kinship networks, which played a significant role in the development of professional theatre in Britain, were the most prevalent form of theatre management until the Companies Act of the 1860s ushered in an era of increasingly corporatist management which inhibited female agency. ${ }^{154}$ Family-firm structures were advantageous to women, Davis argues, because they 'optimized the likelihood that a widow or daughter would inherit and run a business as the titular entrepreneur following a period behind the scenes. ${ }^{955}$ This pattern carried over into colonial society as well. Having evidently gained some experience during her husband's tenure, Mrs Wolfe's assumption of the Princess Theatre lease provides a quintessential example of succession and the influence of family-based business structures.

Closed on the evening of Wolfe's death, the Princess remained under Cooper's direction until the middle of April. During that period, there were ninety-two performances - all in double or triple bill formats. Throughout the two-month season, of more than fifty different pieces, just nine plays were staged more than twice. Such a turnover in repertoire was typical for colonial theatres. While playhouses in larger metropoles could sustain popular interest with seasons of several weeks, even months, of a single piece, the small theatregoing population of colonial Dunedin did not offer managers that luxury. Touring groups could up and move if a location proved unprofitable, for settled theatrical companies without such flexibility, novelty was essential for retaining the patronage of their finite constituency of theatregoers. ${ }^{156}$

\footnotetext{
148 ODT, 23 February 1865, p.6.

${ }^{149} O D T, 25$ February 1865, p.4.

${ }^{150}$ ODT, 27 February 1865, p.4.

${ }^{151} O D T, 25$ February 1865, p.4.

152 Robinson, pp.161-162.

${ }^{153}$ Davis, Economics of the British Stage, p.242.

154 ibid, p. 10 .

155 ibid, p.242.

${ }^{156}$ Simpson, 'Entertainment on the Map', p.159.
} 
Throughout March, Henry Byron's burlesques The Maid and the Magpie and Ill-Treated Trovatore featured heavily in Cooper's programme which capitalised on the comedic talents of company members John Dunn and Robert Dale. Despite price reductions aimed at encouraging better patronage, houses were thin, and a benefit for Mrs Wolfe on 10 March recorded the only full house of the season. ${ }^{157}$ The arrival of Mr and Mrs Charles Dillon on 25 March held much promise. Burlesques, farces, and short comedies had failed to elicit suitable patronage. A shift to more legitimate forms held potential to draw larger crowds. Charles Dillon possessed an established reputation which he had carefully cultivated on the London stage. Having enjoyed a successful spell in Australia, he and his wife had built a colonial theatre career on the back of their West End success.

For the remainder of the season, Cooper took full advantage of Dillon's short contract, staging several serious dramas and seven different works of Shakespeare. In a bid to improve houses, Dillon's record of excellence, and connection to the legitimate stage of the British metropole, was consciously emphasised. Advertising for the first of two productions of King Lear noted his previous performances of the titular role rendered 'with the most unqualified success in London, Edinburgh, Dublin, New York, Philadelphia, Melbourne, and Sydney.' ${ }^{158}$ Shortly afterwards, following a production of The Merchant of Venice played to a house 'not very full', Cooper intimated that 'in consequence of the short engagement' it would 'be impossible for [Dillon] to repeat any of his great characters. ${ }^{\text {, }}{ }^{159}$ Attempts to appeal to the theatregoing public did not precipitate an upsurge in attendance and Dillon's 'great characters' ultimately failed to attract more than middling houses. Overall, despite engaging one of the contemporary stars of colonial theatre, Cooper's season was not notably successful, and she was unable to turn the tide of poor houses (figure 3.4).

Cooper resigned as director of the Princess Theatre in April 1865, moving to Canterbury to fulfil an engagement at Christchurch's Theatre Royal. Shortly after arriving in Christchurch, she and her husband Lionel Harding adapted the Coker's Hall in Cathedral Square and reopened the establishment as the Royal Prince of Wales Theatre in December $1865 .{ }^{160}$ This venture quickly fell into financial difficulty, however, and by March 1866 the Press reported that Cooper and Harding had followed the rush to the West Coast goldfields. ${ }^{161}$ Following a spell on the West Coast, which included performances in Hokitika and at Kilgour's Union Theatre in Greymouth, Cooper and Harding left for Sydney in 1870 and assumed the management of the Adelphi Theatre which they converted into 'a cheap and respectable place of entertainment. ${ }^{162}$

\footnotetext{
${ }^{157}$ ODT, 11 March 1865, p.4.

${ }^{158}$ ODT, 3 April 1865, p.1.

${ }^{159}$ ODT, 7 April 1865, p.4; ODT, 6 April 1865, p.1.

${ }^{160}$ Press (Christchurch), 27 December 1865, p.1.

${ }^{161}$ Press (Christchurch), 16 March 1866, p.2; Timaru Herald, 23 March 1866, p.5; WCT, 24 March 1866, p.3.

${ }^{162}$ GRA, 23 February 1867, p.2; Bell's Life in Sydney and Sporting Chronicle, 8 January 1870, p.3.
} 


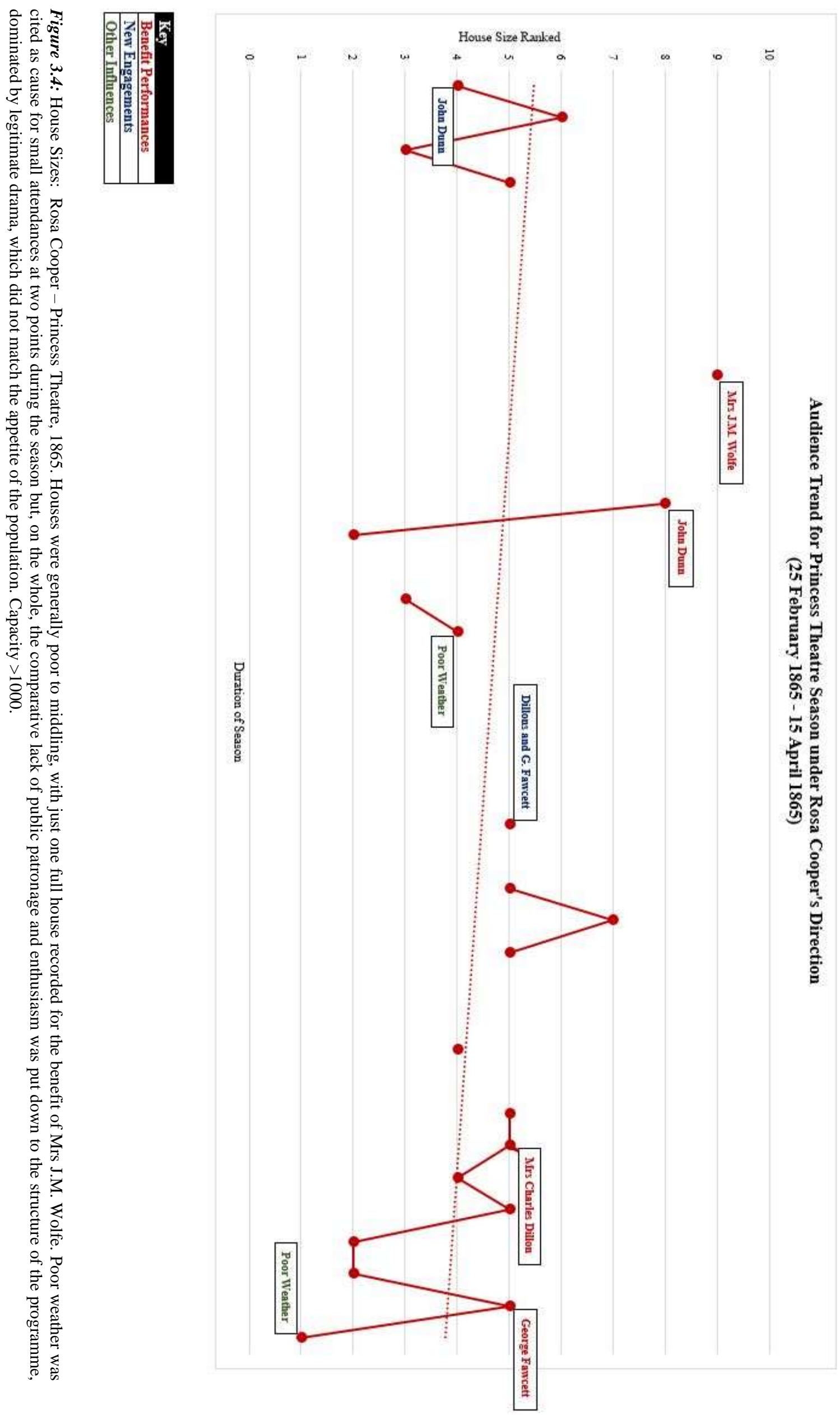




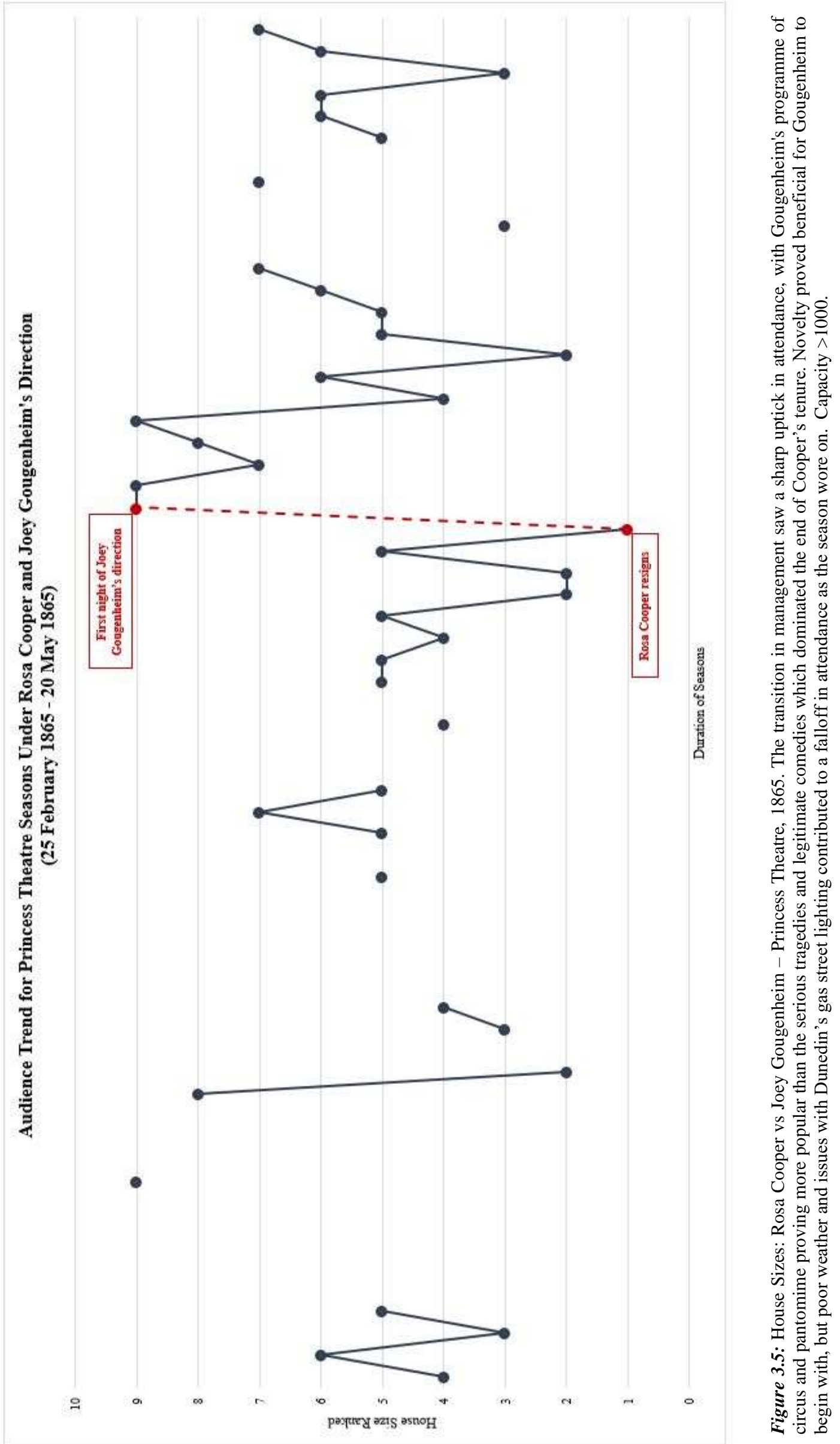


Following Cooper's departure, Mrs Wolfe, continuing in her role as sole lessee, engaged another colonial star to take over the role of 'directress.' 163 Joey Gougenheim was a comic actress of considerable experience and, at 31, already a 'long established' favourite of the American and Australian stage. ${ }^{164}$ Having previously directed theatres in Melbourne and San Francisco, she was familiar with the management scene. ${ }^{165}$ Arriving in New Zealand aboard the Aldinga with 'fame as an actress in light comedy', she was received with familiar affection when she debuted in Tom Taylor's Court and Stage on 26 November 1864. ${ }^{166}$

In April 1865, Gougenheim inherited a venue struggling to pull audiences. Her final performance under Joseph Wolfe the previous December had been staged before a house 'but thinly attended' and Wolfe's endeavours to improve audiences in the latter half of 1864 had failed to 'draw anything like remunerative houses. ${ }^{167}$ Cooper's season had fared little better, culminating in a final night plagued by unpleasant weather and 'very badly attended' in consequence. ${ }^{168}$ As manager, Gougenheim radically altered the repertoire on offer. Combining her own comic skills with the engagement of successful ballet and pantomimists the Leopold Brothers and the Wieland Brothers trapeze act, the previous programme of legitimate theatre was replaced with one tending toward farcical comedies and feats of physical mastery.

The transition in repertoire gave the Otago Daily Times cause to comment that it was 'a remarkable fact' that the 'finished' acting of Charles Dillon could fail to 'draw more than average houses' while a bill of 'ballet, pantomime and the flying trapeze' saw the Princess Theatre 'crowded in every part.' 169 The novelty of the playbill attracted 'crowded' and 'capital' houses in its first week before issues with the gas lighting on Dunedin's streets and further bouts of unfavourable weather both literally and figuratively dampened proceedings. ${ }^{170}$ Houses began to decrease before she resigned in late May, but Gougenheim's programme, which was both light and full of novelty, remained more successful with Dunedin audiences than Cooper's heavy lean toward legitimate drama (figure 3.5).

A short season directed by Lady Emily Don between March and April 1866 will be discussed shortly. On 1 October 1866, a fourth female director, Dolly Green, took over the venue under inauspicious circumstances following the string of 'very slender' houses which had forced Stuart O'Brien to file for insolvency. ${ }^{171}$ Green agreed to assume the management of the Princess on behalf of the company rather than allowing the venue to close temporarily. 'We believe' the Otago Daily Times noted, 'that Miss Dolly Green will prove a good tactician as directress, and that a better name, for its

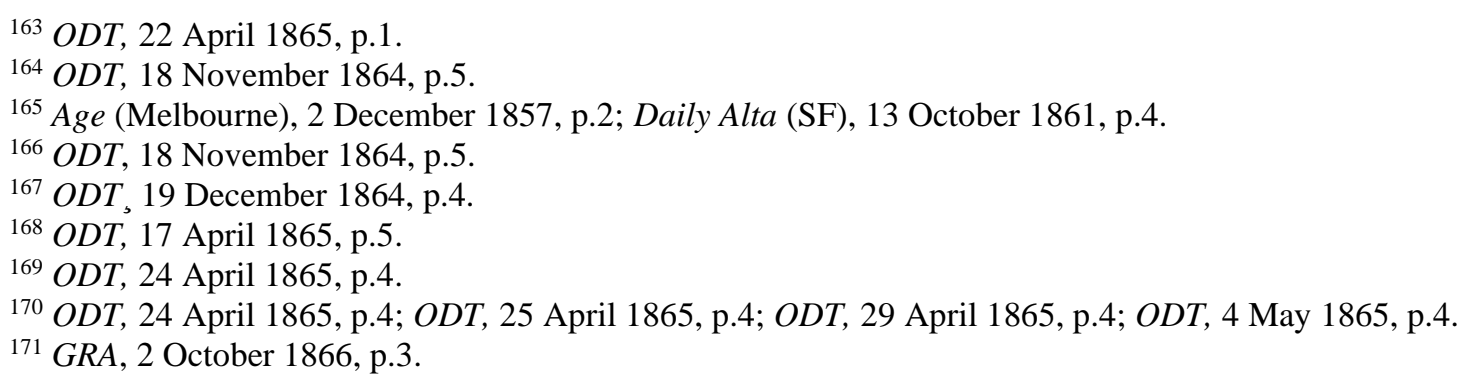


mere effect, could not have been put forward by the company. ${ }^{172}$ Attempting to encourage an upswing in attendance, Green's first move was to lower the prices of admission, allowing half-price access to the boxes before the final piece began after 9 o'clock and reducing entry to the pit to just $1 \mathrm{~s} .{ }^{173}$ The house on opening night was 'not large' despite the price amendments and insistence from the Otago Daily Times that the programme was one that promised to 'attract a crowded house.' 174

Competition between Dunedin's two theatre venues, the Princess and the Theatre Royal, was offered as explanation for the apparent incongruence between the bills on offer and the success enjoyed by each playhouse. A month into Green's period of direction, the Otago Daily Times picked up the familiar argument. 'Dunedin, three years ago' the paper noted 'could not successfully maintain two theatres... attempts since have proved painful failures; and it is useless to attempt to blink the fact, that two theatres cannot now be supported. ${ }^{\prime 15}$ The Dunedin correspondent for the Grey River Argus had voiced similar concerns weeks earlier, questioning how 'in the name of all that is dramatic' Dunedin's theatrical population could hope to sustain two playhouses when 'one theatre would not pay. ${ }^{176}$ Green secured a few large houses, including a crowded house when Gougenheim was re-engaged to appear in The Dowager, a comedic role with which she had garnered public favour in $1865 .{ }^{177}$ A benefit for Green sponsored by the 'ladies of Dunedin' in late October also attracted a full house. ${ }^{178}$ On the whole, performances achieved decidedly moderate houses throughout the season, though fair houses were attracted by performances of Charles Mathews' farce Who Killed Cock Robin?, which - running concurrently on the London stage - was advertised as a fashionable piece (figure 3.6). ${ }^{179}$

Neither Cooper, Gougenheim, nor Green dramatically improved the prospects of the Princess Theatre. It is critical to note, however, that their gender was never utilised as an explanation for runs of poor attendance. As the analysis of debtors' petitions demonstrates, many of their male counterparts produced similar, if not worse, results. Prior to Cooper and Gougenheim's tenures, Wolfe was struggling to break even, and O'Brien had filed for insolvency before Green took charge. The colonial theatre business was not easy to navigate for managers of any description, and male managers battled just as much as their female counterparts to draw full houses. Selected by fellow company members, Green was appointed as director in advance of, and indeed by, several male contemporaries. Gougenheim, for her part, reinvigorated the venue for a short period with her programme of comic and acrobatic entertainments before several uncontrollable complications diminished attendance.

\footnotetext{
${ }^{172}$ ODT, 2 October 1866, p.4.

${ }^{173} O D T, 1$ October 1866, p.1; ODT, 2 October 1866, p.4.

${ }^{174}$ ODT, 2 October 1866, p.4.

175 ODT, 20 November 1866, p.5.

176 GRA, 2 October 1866, p.3.

177 ODT, 26 December 1866, p.1; ODT, 27 December 1866, p.4.

178 ODT, 23 October 1866, p.1; ODT, 24 October 1866, p.4.

${ }^{179}$ ODT, 26 October 1866, p.1.
} 


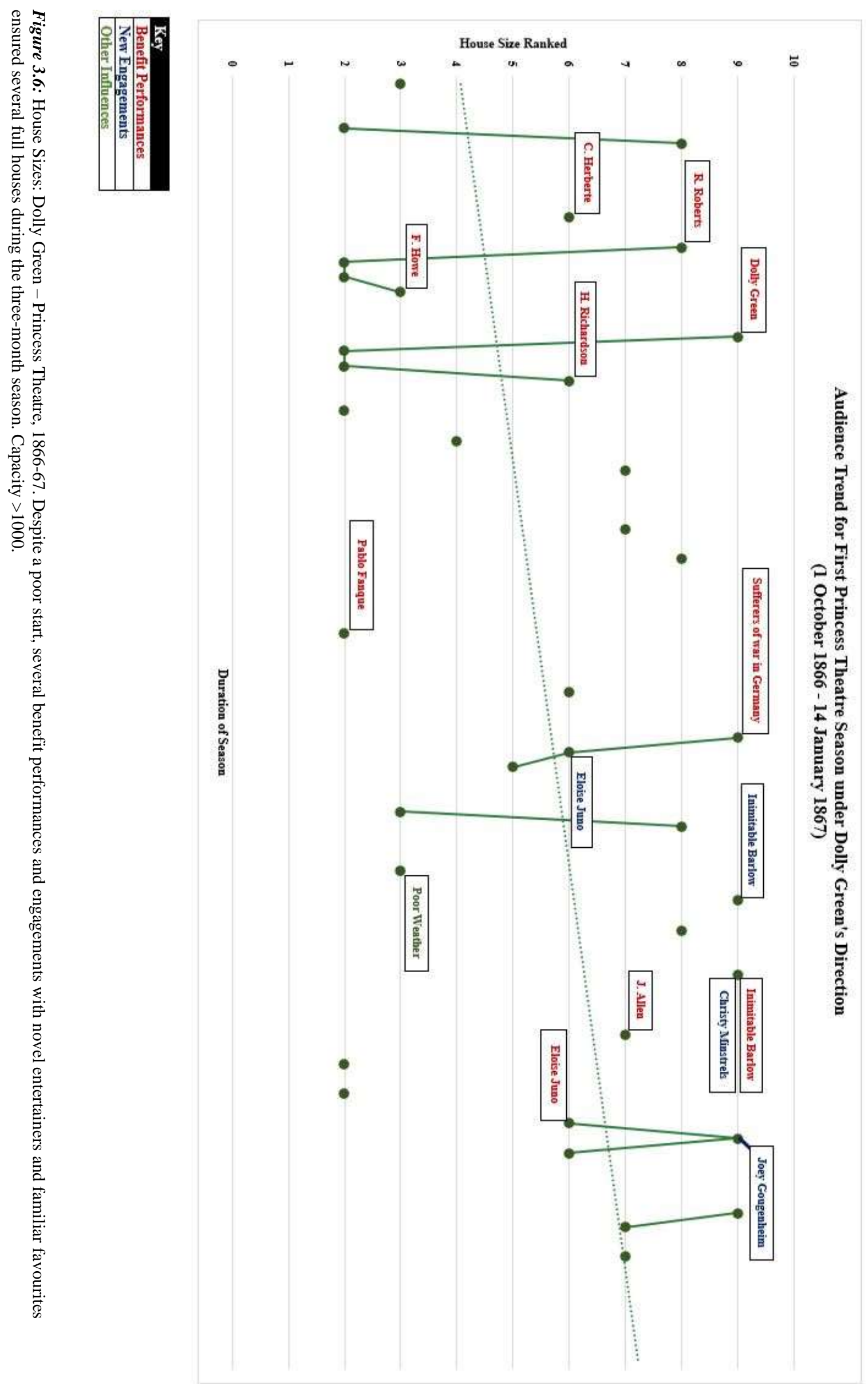




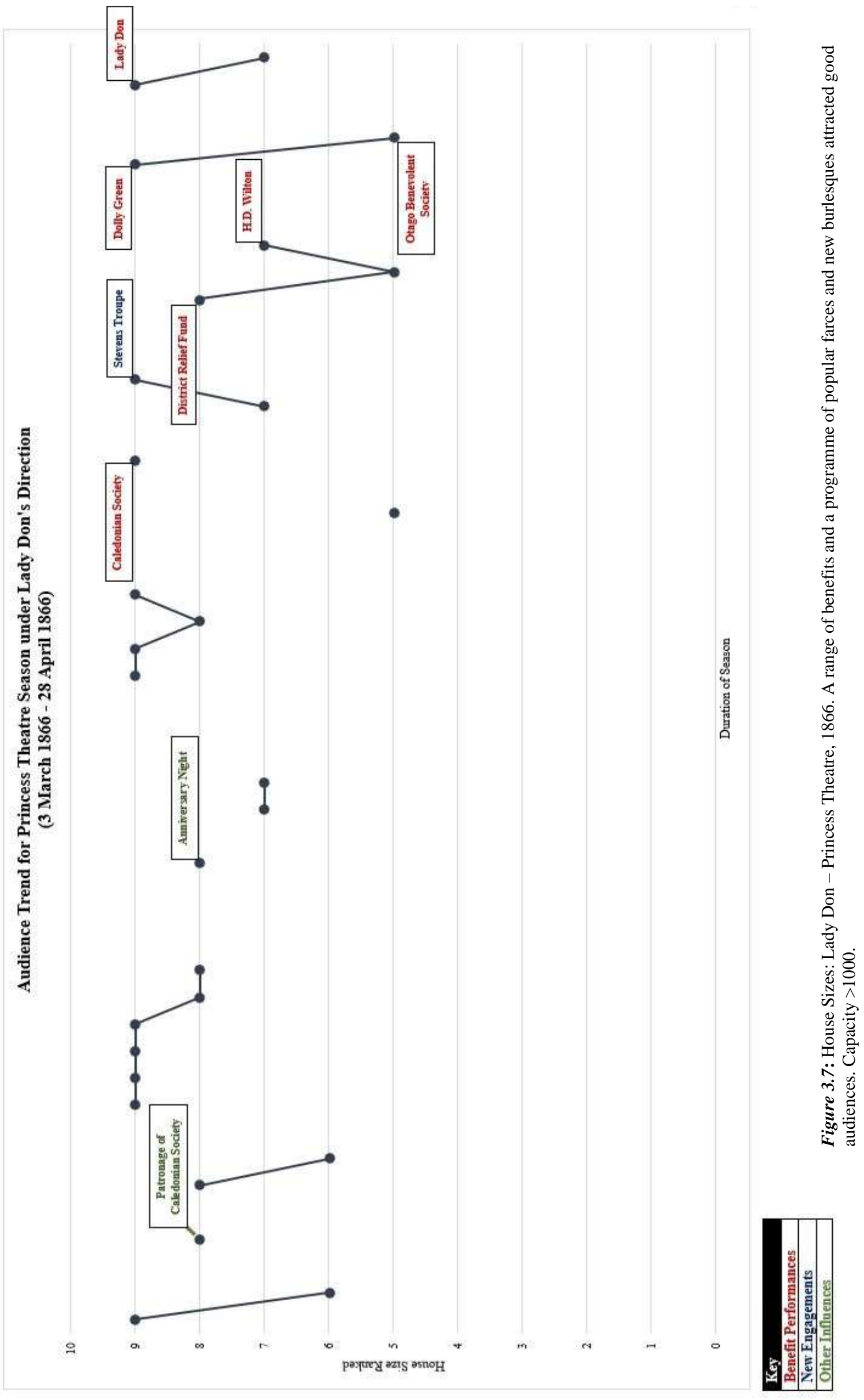


The most successful female manager to entertain Dunedin audiences during the 1860 s was Lady Emily Don who benefited significantly from her established reputation as an actress. Daughter of popular English comedian John Sanders, Lady Don arrived in Dunedin on 26 January 1866, engaged by William Henry Mumford to perform with the Princess Theatre company. ${ }^{180}$ Having established her reputation in Australia performing alongside her husband before his death, her New Zealand debut was a 'genuine success', met with 'tumults of applause' from 'a house crowded to the ceiling. ${ }^{181}$ On 1 March 1866, the Otago Daily Times announced that Mumford's debts, which included failure to cover his actors' wages, had caught up with him. ${ }^{182}$ The next day, a short announcement heralded a change of management and Lady Don opened her season as sole manager the following evening. ${ }^{183}$

Staging a range of spectacular pieces, including an eleven-night run of Ali Baba or the Forty Thieves featuring a 'miniature army' of thirty-eight local boys, Lady Don produced a most successful season (figure 3.7). ${ }^{184}$ Performances in aid of the Caledonian Society and various members of the company drew particularly good houses and the season as a whole was deemed 'in the highest degree satisfactory to all concerned in it' incorporating 'many pieces in a style far exceeding anything before seen in the Colony. ${ }^{185}$ Before departing for Callao in May, a benefit performance held in her honour saw the theatre 'crowded in every part. ${ }^{186}$ Lady Don's season was so popular that her successor Stuart O’Brien faced a significant challenge in soothing public reaction to her departure. ${ }^{187}$

Programme selection most significantly shaped the success of management tenures, and this pattern held true irrespective of the gender of the manager. Directors and 'directresses' both encountered difficulties with repertoire, and those who sought to produce a season laden with legitimate tragedies regularly fared worse than their counterparts who opted for a more comical, less serious, approach. Cooper's contract with Charles Dillon met with surprisingly little success, from a critical point of view and Stuart O'Brien encountered similar challenges following Lady Don's success. After a 'creditable production' of The Merry Wives of Windsor attracted only a small audience, the press suggested that 'after so long a feast in which the light, sparkling, and laughable [had] predominated, there [was] not much present inclining to the more solid legitimate drama.' 188 'Dunedin is not the only place' the Otago Daily Times noted, 'in which there is greater relish for the works of H.J. Byron, the Brothers Brough, and Planche, than for those of Shakespeare. ${ }^{189}$

\footnotetext{
${ }^{180}$ ODT, 27 January 1866, p.4.

${ }^{181}$ ODT, 30 January 1866, p.1.

${ }^{182}$ ODT, 1 March 1866, p.4

183 ODT, 2 March 1866, p.1; ODT, 3 March 1866, p.1.

${ }^{184}$ ODT, 13 March 1866, p.4.

185 ODT, 25 April 1866, p.4.

${ }^{186}$ ODT, 28 April 1866, p.4.

${ }^{187}$ ODT, 11 May 1866, p.4.

188 ibid.

189 ibid.
} 
Management allowed performers to exercise greater artistic control over their own careers, freeing them from contractual constraints to perform parts assigned by other directors. ${ }^{190}$ All four women discussed here took advantage of such freedoms. Cooper, during her tenure, produced several short farces and legitimate tragedies which played to her theatrical strengths. Likewise, Gougenheim's emphasis on comedy allowed her to fulfil roles in which she was both comfortable and well-practiced. Five performances of Charles Mathews' The Dowager saw Gougenheim assume the title role and forty burlesques staged during Lady Don's two-month season capitalised on the manager's own celebrity in the genre.

With a taste of the freedoms which management offered, all four women undertook further work in theatre direction. Cooper managed various theatres in Sydney and Newcastle prior to her departure for Calcutta. Gougenheim, who had leased theatres in Melbourne and San Francisco before arriving in New Zealand, went on to establish and manage the Prince of Wales Opera House in Gulgong, New South Wales. ${ }^{191}$ Green spent the early 1870s touring her own entertainment Seven Ages of Women through provincial Otago before departing for Melbourne to begin a tour of Australia. ${ }^{192}$ And Lady Don, 'recognised as one of the finest singers ever heard in Australia', returned to England and managed the Theatre Royal in Nottingham for a short time before financial pressures forced her to take engagements at music halls prior to her death in Edinburgh, aged 43, in $1875 .{ }^{193}$

Theatre management was a viable prospect for aspiring women in 1860s New Zealand where they were largely critiqued according to their business decisions rather than their gender. Programme selection remained the predominant topic of discussion in the press, and female directors were measured, like their male counterparts, principally by their choice of repertoire. To a significant degree, the Princess Theatre owed its continued existence during the mid-1860s to enterprising female managers. Each of the four women discussed here inherited the direction of the theatre in a time of uncertainty or economic stress. Taking different approaches, with varying levels of fiscal success, all four succeeded in keeping the doors open - no small achievement in a colonial setting constantly demanding novelty and diversity from its entertainment venues.

The theatrical world of mid-nineteenth century New Zealand offered women opportunities unparalleled in other areas. Even as women struggled with the implications of great sex-imbalances in many provinces characterised by the British military presence and goldrush migration, the opportunities for professional theatre women did not differ significantly from those available in metropolitan Britain.

\footnotetext{
${ }^{190}$ Robinson, p.165.

${ }^{191}$ Age (Melbourne), 2 December 1857, p.2; Daily Alta (SF), 13 October 1861, p.4; Sydney Mail and New South Wales Advertiser, 9 September 1871, p.883.

${ }_{192}$ Mount Ida Chronicle, 11 March 1870, p.2; Evening Star (Dunedin), 16 March 1870, p.2; Cromwell Argus, 16 March 1870, p.4; Dunstan Times, 18 March 1870, p.2; Tuapeka Times, 24 March 1870, p.4; Star (Ballarat), 12 December 1870, p.2; Kyneton Guardian, 17 December 1870, p.2; Argus (Melbourne), 29 December 1870, p.2; Australasian (Melbourne), 31 December 1870, p.19.

${ }^{193}$ Evening News (Sydney), 28 December 1875, p.3; Herald (Melbourne), 27 September 1875, p.3.
} 
Actresses and theatre managers were treated with remarkable respect by the colonial press. As Davis has noted, the protective power of an established reputation played a significant role in informing critical response. The scarcity of women in colonial settings was also significant. In largely homosocial environments, the opportunity to see women perform on stage attracted male theatregoers and elevated performers to celebrity status, allowing them to build significant professional reputations as colonial stars which offered some protection against lewd accusations and intrusion into their private lives.

In colonial settings, as in Britain, the self-sufficiency of theatre women, both financially and in terms of professional reputation, underscored social discomfort or anxiety around their social role as women. While they continued to challenge conventional constructions of modest femininity, female performers were less regularly condemned for their ambiguous performance of gender in colonial New Zealand than in Britain. Sexualisation of performers and genres was used elsewhere to degrade the reputations, and restrict the freedoms, of theatre women, but such commentary was notable in New Zealand largely for its absence. The comparatively low level of moral scrutiny endured by colonial performers, at least in the public sphere, is readily observed in the lack of general equivocation between performance and prostitution. Prostitutes continued to openly utilise colonial theatres as public spaces to solicit clients. However, in New Zealand this parallel was rarely, if ever, employed to condemn theatre women, individually or collectively, or to discredit theatre more broadly.

Established reputations provided some buffer. The extent to which it was possible to emphasise distinction between theatre and reality also played a part in preserving the ambiguous propriety of female performers. The speed with which the press jumped to the defence of Julia Mathews in Hokitika is a notable example, with supporters quick to define and defend her use of her maiden name as theatrical convention rather than a transgression of external gender dynamics. It is worth noting also, that while Amelia Poole's renditions of Hamlet and Othello were challenged on gendered terms, in appropriate genres or roles female impersonation of male characters on stage was generally accepted. Theatre women earnt an income, established professional reputations on their own terms, and occupied a recognised space in public life. Elsewhere, the benefits of a theatrical career were more heavily constrained by external societal convention, but this proved less of a barrier in colonial New Zealand where professional entertainment was scarce.

Nonetheless, theatre women still did not fit colonial definitions of femininity associated with stability and domesticity. Actors' necessary itinerancy and lack of settlement did not coalesce with the image of the ideal colonial woman. The professional lifestyle of the stage, which operated unseasonable hours late at night, also positioned performers and 'directresses' in opposition to the gendered roles of wife and mother. If performers and managers did care for children, this side of their life was rarely publicised. Joey Gougenheim, who had four children between 1866 and 1870, took extended breaks from the stage after each birth which received little attention from the press. Moving back and forth between Dunedin, Victoria, Auckland, and New South Wales, the family was accompanied by a female servant whose assistance presumably enabled Gougenheim to return to work. Some theatre women left 
the stage after marriage. Marian Dunn, for example, daughter of a successful theatre family who was developing a reputation with Melbourne audiences, retired after marrying peripatetic philosopher Marcus Clarke in $1869 .{ }^{194}$

Analysis of performers and theatre managers extends traditional understandings of female employment in colonial society. Theatre work was the exception not the norm. Nonetheless the fact that women were able to participate as both performers and managers with public support highlights the extent to which the theatre, and its position as an industry 'somewhat outside the boundaries of respectable society' allowed women to negotiate structures of gender from a different platform. ${ }^{195}$ The degree to which the colourful, often raucous, world of the auditorium further threatened agendas promoting respectable settlement will be examined in the following chapter.

${ }^{194}$ ODT, 3 August 1869, p.3.

${ }^{195}$ Curry, p.4. 


\section{Chapter 3}

\section{'The Better the Stage, the Better the Town': Theatre and Colonial Respectability}

In 1868, a long letter from a prospective resident of Auckland appeared in the Daily Southern Cross. Initially attracted by reports of lucrative goldfields in the Coromandel, the correspondent had been pleasantly surprised by the state of public amusements in the city and congratulated the settlement once condemned for its remarkable dullness. 'I look forward to a great future in Auckland, and should like to see your institutions flourish,' in addition, the author noted:

I look upon your theatre as a credit to the spirit and enterprise of its projectors, and the first-rate plays placed upon the stage, and the very orderly and well-conducted audiences, as an evidence of the people. The better the stage, the better the town. ${ }^{1}$

Auckland's theatre scene had flourished since the introduction of regular dramatic entertainments by the $58^{\text {th }}$ regiment in the late 1840s. As the settlement expanded, colonial theatre entrepreneurs Mrs W.H. Foley, George Buckingham, and various other visiting entertainers had invested considerable capital and time developing a lively civilian theatre scene. Foley's Theatre Royal, constructed at great pace in February 1856, attracted and delighted theatregoers with its professional entertainment. ${ }^{2}$ By 1868 , the Royal had been supplanted by the Prince of Wales at the repurposed Brunswick Hall on Queen Street.

The repertoire on offer at the Prince of Wales was indicative, the Daily Southern Cross correspondent suggested, of Auckland's educated public, and provided favourable testament of the progress of society in the former capital. With its wide social reach, extending beyond the written word in both access to printed material and barriers of literacy, contemporaries viewed theatre and its success or failure as a unique representation of civic progress and public intelligence, values, and taste. 'I hold', the prospective settler concluded:

that the stage should be one of the strongest of all secular aids towards intellectual refinement of the people... if they who wish well to English literature disdain to stretch out a hand in friendship to the players, they not only assist to the ruin of what has hitherto been one of the chiefest [sic] strongholds of good wit, but their neglect snaps

\footnotetext{
${ }^{1}$ DSC, 23 October 1868, p.4.

${ }^{2}$ David Burn, 'David Burn Diary, 10 October 1855 - 15 September 1858', Microfilm: CY 1094, Ref: 844931, Mitchell Library, Sydney.
} 
one of the strongest bonds of union between true literature and the main body of the people. ${ }^{3}$

Emphasising its importance as a civic institution, the author highlighted the centrality of theatre within the social life of Auckland. The stage communicated directly with its audience and the opportunity for collective social engagement epitomised the significance of theatre as a vehicle for education and intellectual refinement.

Two broadly opposing narratives informed social responses to theatre in Victorian Britain and colonial society. On one hand, supporters argued that theatre exerted a civilizing influence through performances of a refining character - opera, legitimate dramas and comedies - which educated patrons from across the social spectrum and offered opportunities to exhibit or accrue social capital. On the other was the notion that theatre corrupted the mind and threatened the very foundations of respectable society. Entwined with drunkenness, prostitution, and general disorder, theatre, particularly bawdy variety performances and sensation melodramas staged in lower-class establishments, posed a unique threat to social civility. Thus, theatre acted as a barometer of broader cultural and social sophistication whilst simultaneously hovering on the verge of a descent into degeneracy and vice.

In London, divisions between West and East End playhouses were constructed along class lines. The high art of the West End offered moral instruction and attracted audiences who personified selfregulation and decorum. By contrast, popular working-class theatre was viewed as disreputable, illegitimate, and dangerous. ${ }^{4}$ Suspicion about the moral quality and degrading or elevating effects of theatre carried over into settler society. In North America, theatre did not find a ready home in what was 'an immediately hostile environment. ${ }^{5}$ Puritan concerns about the exposure of the body on stage and display of intemperate emotions were particularly pronounced. In colonial New England, 'boundaries were to be respected, not transgressed, and the theatre...had always been about transgression. ${ }^{6}$ While less widespread than in the United States, similar sentiment was expressed in New Zealand. Some colonists, especially those with close connections to the Evangelical and Protestant churches, fearing the effect theatre would have on the piety and moral righteousness of the population, offered particularly vocal opposition. Anxiety over the corrupting power of amusement and venues where social mixing went unchecked, had a profound effect on colonial discourse. ${ }^{7}$ However, promotion of the theatre as a source of education, social improvement, and civility also enjoyed significant support.

The following chapter takes these contrasting views of theatre as corrupting or civilizing to analyse the extent to which discussion of, and attendance at, the theatre was entangled within a broader discourse of colonial respectability. An analysis of how theatre was perceived by patrons, critics, and

\footnotetext{
${ }^{3}$ DSC, 23 October 1868, p.4.

${ }^{4}$ M. Scott Phillips, 'Rational Entertainment, Music Hall and the Nineteenth-Century British Periodical Press',

Theatre History Studies, Vol.22, 2002, pp.195-213; Davis and Emeljanow, pp.93-108.

${ }^{5}$ Bigsby and Wilmeath, p.1.

${ }^{6}$ ibid, pp.1-2.

7 ibid, p.2.
} 
promoters assesses the extent to which these colonial perceptions built upon existing metropolitan rhetoric. Analysis of theatre's regulation examines the comparatively sparse instances of government intervention in New Zealand to interrogate the official stance on theatre as a source of entertainment. The analysis then takes us into the auditorium, investigating the behaviour of colonial audiences, how they responded to the stage, and the significance of the theatre as a space of public gathering, imagination, and excitement. Examining how managers responded to social and legal pressures to maintain 'civilized' venues and stage rational amusements opens space to assess how theatregoing's promotion and regulation reflected broader standards of respectable behaviour. Incorporating an analysis of disorder, the chapter concludes with some discussion of how playhouses were used by different groups and the extent to which criticism of and support for theatre and theatregoing was influenced by a developing discourse of respectable amusement.

\section{Victorian Respectability and Colonial Perceptions of Theatre}

Several factors underpinned anxieties and arguments put forth by those opposed to theatres as providers of public amusement. Some argued that the frivolity of theatre promoted idleness and lured 'rational minds' away from productive pursuits. The heightened emotion of stage and auditorium further threatened personal and social productivity by depicting, and providing public space for, raucous behaviour at odds with broader codes of conduct. In addition, the extent to which theatregoing exposed patrons to social and physical threats beyond the stage - thefts, violence, drunkenness, prostitution, and general disorder - was enhanced in colonial settings where access to fewer entertainment venues saw patrons from across the social spectrum crammed together in the same auditorium. Addressing the inherent 'social uneasiness' surrounding touring theatricals, Berkin notes that theatres were presented 'not only as novel and egalitarian, but also as dubious sites of transformation and social mixing."

Concern that theatre corrupted and degraded wider society was not restricted to large urban centres. In 1844, one visitor to Auckland's newly established Victoria Theatre recorded their astonishment at the volume of 'loudly repeated expressions of pollution' and 'successions of fights and uproar. ${ }^{9}$ Deemed 'most discreditable to the management', the venue had descended into such disarray, the author suggested, that it was shocking that law enforcement had not 'interfered in some way to enforce something like decorum and decency. ${ }^{, 10}$ Responding to concern about the conduct of patrons frequenting the playhouse, the press expressed hope that the state of affairs would not prejudice the public against theatre in general. 'We should be sorry', the editors noted, 'to see any rational amusement prevented so long as it is conducted with respectability.' ${ }^{11}$

\footnotetext{
${ }^{8}$ Berkin, p.4.

${ }^{9}$ Auckland Chronicle and New Zealand Colonist (Auckland Chronicle), 4 April 1844, p.3.

10 ibid.

${ }^{11}$ ibid.
} 
Respectability was an elastic concept. Analysing its definition in contrast to vice in Victorian Britain, Mike Huggins notes that the two ideologies operated interdependently. 'Reformers needed unrespectable pleasures', Huggins argues, 'to act as a counter-point to make their own lives feel worthwhile...respectability and un-respectability needed each other. ${ }^{12}$ Respectability, and the performance thereof, permeated all aspects of British society shaping how people from all classes worked and socialised. Viewing leisure as a 'vehicle for character building and self-improvement', Peter Borsay argues that the advent and promotion of 'rational' amusement epitomised entertainment and recreation during the mid-Victorian period. ${ }^{13}$ Leisure offered a means of converting wealth into status, and public spaces such as theatres became 'arenas in which cultural consumption and display took place. ${ }^{14}$ Different brands of amusement variously promoted or undermined wider notions of respectable behaviour. Struggling to distinguish themselves from more raucous music hall amusements, theatres occupied an uncertain position for prospective patrons seeking to utilise public space and conspicuous leisure time to cultivate an image of respectability. 'As people had to leave the security of their homes to venture to public spaces,' Carolyn Eichin argues, 'anxiety about the respectability of a venue came under scrutiny. ${ }^{, 15}$

In garrison settings, theatre offered an innocent and productive activity which helped divert attention of the rank and file from drink and other disreputable leisure pursuits. Garrison life was monotonous, and boredom threatened discipline. 'Military theatres have experienced the judicious support of many Commanding Officers', the Daily Southern Cross noted in 1850:

for the occupation afforded to many, not merely in acting, but in scene painting, carpentering, tailoring, and all the varied requirements of the histrionic art, not only engages the leisure of the parties so employed, but attracts a considerable share of attention from a large number of spectators anxious to witness and ready to appreciate a comrade's performance... As an auxiliary of civilization, as an incentive to excellence in taste, as the promoter of vigour and eloquence in composition, we have ever held the dramatic art to be preeminent. Its teachings are invariably those of virtue; its unfoldings constantly exhibit, (and that in the most striking colours), the sin and the folly of vice... are not its inculcations as likely to produce their effect upon the mind of the soldier as upon that of the civilian? ${ }^{16}$

While the stage held some license to critique and satirise as well as entertain, garrison theatres trod a finer line than their civilian counterparts and the entertainment on offer adhered to strict guidelines of propriety. Announcing the opening of the military theatre at Whanganui in 1857, the press noted that the venture would provide 'a rational, innocent source of amusement' where 'nothing immoral,

\footnotetext{
${ }^{12}$ Mike Huggins, Vice and the Victorians, (London: Bloomsbury, 2016), p.177.

${ }^{13}$ Peter Borsay, A History of Leisure: The British experience since 1500, (Houndmills: Palgrave Macmillan, 2006), p.90.

${ }^{14}$ ibid, p.90.

${ }^{15}$ Eichin, p.81.

${ }^{16}$ DSC, 9 April 1850, p.2.
} 
irreligious, or even political [would] be attempted or allowed. ${ }^{17}$ Theatre, when produced with propriety, exerted a 'wholesome influence' and provided rational entertainment for garrisoned troops. ${ }^{18}$

Histories of British theatre regularly adopt a progressive narrative which paints the development of entertainment during the nineteenth century as a continuous march toward greater respectability and social refinement. Such interpretations, which culminate in the triumphant rise of the respectable West End as Victorian theatre climbed 'slowly out of a swamp of mob rule and workingclass domination' are, as Michael Booth has noted, oversimplified and largely ignore the significant diversity of theatrical amusement which continued to cater to demands of different audiences as the century progressed. ${ }^{19}$

Repertoire and patronage significantly shaped public perception of theatres, and playhouses could go one of two ways when it came to promoting respectability. On one hand, Eichin argues, theatres geared toward more 'cultivated' audiences devoted themselves to 'uplifting legitimate theatricals' and implemented seating patterns which actively distinguished between different classes of playgoer. ${ }^{20}$ The consumption of rational amusement offered patrons a means of cultivating their own respectable image. For some playhouses, however, the commercial nature of professional theatre saw respectability side-lined by profit-driven managers focused on the impact of repertoire on house receipts. Such venues typically presented more salacious material and paid little heed to how this repertoire impacted the character of their paying patrons. ${ }^{21}$

Divisions between venues were readily observed in Britain where assumptions about the propriety and quality of music hall amusements directly influenced the reputation of performance-based entertainment more broadly. ${ }^{22}$ Fearing that their own venues were being 'swamped' by 'novel entertainments without proper boundaries and with no discernible improving content', Jacky Bratton argues that legitimate theatre managers utilised the entrenched stereotype of the bawdy music hall to construct their public image in opposition to those establishments. ${ }^{23}$ Openly combining amusement with relaxation, eating, and drinking, music halls attracted a lower class clientele which was commonly depicted as vulgar and inferior. Such interpretations carried over into colonial society. In 1874, expressing concern about the character of entertainment venues in the city, Dunedin Resident Magistrate John Bathgate argued against licensed houses having the 'privilege of concert rooms or music halls' on the grounds that, in addition to Dunedin's two professional theatres rendering them

\footnotetext{
${ }^{17} \mathrm{TH}, 11$ July 1857, p.3.

${ }^{18} \mathrm{TH}, 5$ October 1861, p.2.

${ }^{19}$ Michael R. Booth, Theatre in the Victorian Age, (Cambridge: Cambridge University Press, 1991), p.9.

${ }^{20}$ Eichin, p.81.

${ }^{21}$ ibid.

${ }^{22}$ Dagmar Kift, The Victorian Music Hall: Culture, Class and Conflict, (Cambridge: Cambridge University Press, 1996); Phillips, pp.195-213.

${ }^{23}$ Bratton, West End Stage, pp.12-13.
} 
unnecessary, such venues were generally 'found to be the resort of thieves and prostitutes, and productive of crime. ${ }^{24}$

Those who presented plays with no obvious refining or moralising impact for commercial gain, could be accused of profiting from the moral degradation of their patrons and broader society. Emphasis on 'rational amusement' allowed proponents of the theatres to define themselves and their taste against the rowdy entertainment of music halls and other low-class establishments. Following the Auckland Chronicle correspondent's condemnation of the Victoria Theatre for its patrons' 'disgraceful' conduct, the paper highlighted the potential for the opposite to prevail. George Buckingham's Fitzroy Theatre, which had temporarily closed its doors, was presented as a case in point. 'While Mr Buckingham's Theatre was open', the editor noted, 'we had a truly respectable place of amusement... and I have no doubt that upon his re-opening the Public will give him many golden opinions that they appreciate his determination to uphold the respectability of so rational an amusement. ${ }^{25}$

Colonial theatregoers, performers, and managers operated with awareness of the respectability exemplified by London's West End, which categorised and hierarchised repertoire, venues, and patrons. The number of music halls in Britain, and particularly London, grew exponentially during the nineteenth century, further cementing repertoire divisions between venues. In colonial New Zealand, the demand for novelty and comparative sparsity of venues meant that repertoire was often mixed. As a result, the distinction between theatre and more disreputable forms of entertainment was not as strong, nor so easily identified, in colonial towns. Nonetheless, colonial managers devoted considerable time and effort to distinguishing themselves and their establishments from more raucous and degrading amusements. Challenging pre-existing assumptions about the inferiority of colonial entertainment, managers actively emphasised their awareness of, and adherence to, metropolitan standards. Announcing the imminent opening of his Prince of Wales Opera House in Hokitika in 1866, for example, James Bartlett declared his intention to ensure his establishment operated in a manner in keeping with metropolitan expectations. 'The greatest order will be maintained throughout the whole establishment' Bartlett announced a few days before opening night, 'and everything conducted on the same plan as the principal Theatres at the West End of London. ${ }^{26}$

By 1870, Reverend Robert Ward noted with much disdain, a troublesome appetite for theatrical entertainment had engulfed New Zealand. 'The theatre is here', Ward reported, 'not in the perfection of its trappings and song and eloquence, which may be occasionally seen and heard in the principal play-houses of Great Britain, but though of lower pretensions, the attractions are strong, and we fear that the harm done is great. ${ }^{, 27}$ Time wasted in the frivolous pleasure of playgoing threatened the hard-

\footnotetext{
${ }^{24}$ John Bathgate to the Honourable Minister of Justice, 5 June 1874, 'Licensing Act of 1873 (Instructions and Correspondence Relating to)', AJHR, 1874, Session I, H-21, pp.3-4.

${ }^{25}$ Auckland Chronicle, 4 April 1844, p.3.

${ }^{26}$ WCT, 15 March 1866, p.3.

${ }^{27}$ Rev. Robert Ward, Life Among the Maories of New Zealand: Being a Description of Missionary, Colonial and Military Achievements, (London: G. Lamb, 1872), p.261.
} 
working diligence of the colonial population. Opposition to theatre, which drew significant support from religious factions of colonial society, often centred on its intoxicating tendency to draw rational minds away from other duties and more respectable leisure pursuits.

Gold towns themselves threatened the respectability of wider settler society in part, Benjamin Mountford argues, because the extent to which goldrush society inverted established social structures, and organised forms of settlement, made many uneasy. ${ }^{28}$ In addition, goldrush populations were fundamentally unsettled and engaged in labour where success was perceived to depend more upon luck and chance than hard work. ${ }^{29}$ Entertainments servicing these communities were equally suspect. Arriving on the West Coast in 1866, Caroline Chevalier noted that Hokitika's population of 'queer dreadful men' was well serviced by '90 public houses. ${ }^{30}$ John Watmuff observed a similar scene in Dunedin in 1862 where hotels were filled with 'men drunk \& getting drunk gambling, cursing \& swearing. ${ }^{31}$ Gold towns were disorderly, unsettled, and chaotic. Some characteristics which marked them as a threat to proper settlement also made them an ideal target market for entertainers. ${ }^{32}$ Transient wealth, coupled with a population eager to spend and seeking amusement, attracted many prospective performers and managers. In settlements which were already hotbeds of social vice, theatre could offer a comparatively respectable source of leisure. No matter what their intention, however, the viability of managers' programmes was subject to the demands of their constituency of theatregoers.

Colonial towns were highly sensitive to ideas of progress and reputation. The extent to which the character of repertoire was taken as direct reflection of the social calibre of its audience played a significant part in shaping responses to theatre in New Zealand. With the nature and success of different genres interpreted as indications of the intelligence and sophistication of the broader population, some groups went to great lengths to ensure that the entertainment on offer was in step with whatever definition of respectability they endeavoured to project. Those identifying themselves as supporters of theatre recognised the threat that disorderly audiences and lewd productions posed to the reputation of both the venues and those who patronised them. Opponents condemned the playhouses as frivolous, raucous, and outright dangerous while proponents argued that theatre and amusement were vital for public growth. Dunedin residents fell on both sides of the argument as disputes occupied correspondence columns of the local press during the 1860s.

Debate over the value of theatre was ignited by the establishment of Dunedin's two professional playhouses. Writing to the editor of the Colonist in August 1862, a correspondent styling himself

\footnotetext{
${ }^{28}$ Benjamin Mountford, 'The Pacific Gold Rushes and the Struggle for Order', in Benjamin Mountford and Stephen Tuffnell (eds.), A Global History of Gold Rushes, (Oakland: University of California Press, 2018), pp.99-100.

${ }^{29}$ Goodman; Herbert, pp.339-368.

${ }^{30}$ Caroline Chevalier, 'Chevalier, Caroline: A short description of a journey across the South Island of New Zealand from East Coast to West Coast and back from West to East Coast', Ref: MS-0143, Hocken Library, Dunedin, p.43.

${ }^{31}$ John Henry Watmuff, 'The journals of John Henry Watmuff - New Zealand extracts, 1861-1864/transcribed by Stephen Arnold (1861-1864(2006))', Ref: Misc-MS-2000, Hocken Library, Dunedin.

${ }^{32}$ S.N. Brown in E.M. Story, 'Stories of the Gold Diggings', Ref: fMS-Papers-7868, ATL.
} 
'Enquiry' berated the new establishments and theatregoing public. ${ }^{33}$ Fearing that the frivolity and vice promoted by this brand of entertainment would fatally undermine the moral integrity of the staunch Presbyterian settlement, the writer declared that there was 'not one benefit, not one advantage...likely to accrue' from the venues threatening the decent, god-fearing people of Otago:

Personal experience has taught me that attendance on the Theatre invariably dissipates the mind, and leads it away from God, the source of all good. The excitement of the Theatre produces a kind of intoxication worse in its permanent effects than that produced by alcoholic drinks. The one affects the mind only through the body, and hence the mind protests against the slavish subjection of its powers, to the lust of the flesh; but the other is a lust of the mind itself, intoxicating it, and laying it open to the influence of other vile passions. ${ }^{34}$

Biblical condemnation of theatres and theatregoers was a recurring theme. Parishioners of Knox Church had been treated to the likening of the pit of the theatre to the bottomless pit of Hell a short time before Enquiry's tirade appeared in the press. Such rebukes, however, consistently attracted responses from supporters of the playhouses. One respondent declared that 'until the denouncers of the theatres [were] able to bring something in the shape of tangible reasoning to bear support of their position', he, as a frequent patron, would 'not feel disposed' to give up what he believed to be 'an innocent enjoyment. ${ }^{35}$ Others were more forceful in their defence. One declared:

The Drama, far from injuring society, is one of the great instruments of its refinement and exaltation...it lifts the mind above ordinary life, gives it respite from depressing cares, and awakens the consciousness of its affinity with what is pure and noble. In its legitimate and highest efforts, it has the same tendency and aim as Christianity. ${ }^{36}$

Enquiry argued that theatre was productive of vice and disorder, declaring that the fiction central to theatre degraded both moral and cognitive function, acting as a 'slow poison' which painted 'vice with a thin veil.' Supporters of the new dramatic amusements, by contrast, argued that the imaginative power of the stage had a positive effect on society, alleviating monotony and even acting as a moralising force.

Those who vehemently defended theatre as a public good did not seek to do so by utterly dispelling the notion that it could generate vice and disorder. Rather, they emphasised the influence of individual character. One 'friend of the Drama' wrote to the Lyttelton Times in 1857 to express such an opinion. 'It has been asserted', the writer noted, 'that public amusements, and particularly those of the theatre, are open to serious objections of encouraging vice and immorality; but where shall we not find opportunities for the encouragement of immoral feeling if we allow it to influence us? ${ }^{37}$ Enquiry's opponents expressed similar sentiment. The Otago Daily Times, which reaped commercial benefits from the playhouses, responded as such to the letter which they had republished in their columns. 'We

\footnotetext{
${ }^{33}$ Republished in $O D T, 11$ August 1862, p.6.

${ }^{34}$ ODT, 11 August 1862, p.6.

${ }^{35}$ ODT, 16 August 1862, p.5.

${ }^{36}$ ODT, 11 August 1862, p.5.

${ }^{37}$ Lyttelton Times, 2 September 1857, p.4.
} 
fearlessly aver', the editors stated, 'that the drama is a most meritorious institution and the fact that "Enquiry" and others, see evil in it, reflects on themselves, and not on the object of their reflections. ${ }^{38}$

\section{Legal Regulation: The Licensed Theatres' Ordinance (1862)}

Dunedin politicians quickly set about putting systems in place to monitor the ever-expanding number of entertainment venues in 1862. While outright bans were rare, some legal measures offered police and other officials a direct means of regulating amusement, thereby preserving their settlement's reputation. Analysing theatre regulation in Britain, Judith Flanders argues that the powers granted under the 1737 Licensing Act to censor plays before their production reflected the extent to which theatre threatened the stability and decorum of society at large. 'In fact,' she argues, 'if theatre had not been so much fun for the very people who feared its influence on others, it probably would have been banned entirely. ${ }^{39}$

The lengths lawmakers were willing to go to restrict and dictate the content of the stage highlights the power theatre held as a colourful and accessible source of public amusement. In Britain, stringent censorship laws and far-reaching state controls differentiated theatre from other forms of popular culture. Literature had not been subject to censorship prior to publication since the late seventeenth century and even within the Licensing Act (1695) playwrights were more heavily censored than other writers. As the theatregoing population expanded during the nineteenth century, pressure to amend legislation accused of stifling the development of legitimate drama also grew. The Theatres Regulation Act (1843) relaxed some restrictions in Britain and deconstructed patent theatre monopolies on the production of legitimate drama, but the stage continued to be treated with suspicion by lawmakers. ${ }^{40}$ Theatre's extensive reach and significant popularity 'represented anarchy', Flanders argues, but despite various pieces of legislation introduced and modified to keep pace with the everchanging medium, 'control of its exuberant, riotous heart was never entirely achieved.' ${ }^{41}$

In New Zealand, attempts to regulate theatre developed alongside concern over the threat to civilized settlement posed by unchecked goldrush migration. The demographic and urban landscape of Dunedin altered drastically during the 1860s, and Otago politicians quickly set about introducing several measures 'urgently demanded by the necessities of the times' to exert some control over the rapidly expanding population. ${ }^{42}$ Twenty-five bills, aimed at regulating all manner of expanding public services and occupations, were tabled by the Provincial Solicitor in 1862. Among them was the

\footnotetext{
${ }^{38}$ ODT, 11 August 1862, p.4.

${ }^{39}$ Flanders, p.292; David Thomas, 'The 1737 Licensing Act and Its Impact', in Julia Swindells and David Francis Taylor (eds.), The Oxford Handbook of the Georgian Theatre, 1737 - 1832, (Oxford: Oxford University Press, 2014), p.101.

${ }^{40}$ Schoch, p.332.

${ }^{41}$ Flanders, pp.292-293.

42 'Votes and Proceedings of the Provincial Council of Otago', Otago Provincial Government Gazette, Session XVI, 1862, (Dunedin: Printed by Authority, Daniel Campbell, 1863), p.2.
} 
Licensed Theatres' Bill, the passage of which introduced a level of government oversight of public amusement then without precedent in colonial New Zealand.

The Licensed Theatres' Ordinance (1862), designed to regulate 'places of public exhibition and entertainment', enabled the Otago Provincial Government to manage, to some degree, the entertainment on offer in the region. ${ }^{43}$ Requiring all venues staging amusements for 'hire gain or reward' to purchase a yearly license at no more than $£ 5$ per month, the Ordinance offered the Provincial Government an opportunity to capitalise economically on the increasing popularity of the theatres. Wide-reaching in scope, the regulations required a license for the performance of any 'interlude, tragedy, opera, comedy, stage play, farce, burletta, melodrama, pantomime, or any stage dancing, tumbling or horsemanship or any other entertainment of the stage whatsoever' which people paid to attend. Critically, the Ordinance also defined 'any stage play or other entertainment of the stage' performed alongside the sale of 'spiritous or fermented liquors' as entertainment for hire. ${ }^{44}$

While less restrictive, the Ordinance bore some striking similarities to Robert Walpole's Licensing Act introduced in Britain in 1737. Both statutes targeted commercial amusement, staged for 'hire Gain or reward', and barred performances in unlicensed venues. The English legislation also heavily restricted the number of new licenses which could be issued, and managers in Walpole's London faced $£ 50$ fines for staging unlicensed entertainments. While the Otago Provincial Council left pathways for licensing, there were repercussions for managers who did not comply. ${ }^{45}$ In Otago, the focus was not so much on preventing an increase in venues for public amusement as ensuring that the amusement was of a tenor in keeping with the projected tone of the settlement. The Ordinance sought to safeguard the 'preservation of good manners, decorum or public peace', through regulation of both the content and patronage of the playhouses. ${ }^{46}$

To ensure the propriety of repertoire, the Ordinance explicitly targeted 'stage entertainments offensive to morals. ${ }^{47}$ Fines of $£ 50$ threatened any who produced amusements of a 'lewd, indecent or immoral description' and the Superintendent reserved the right to prohibit the presentation of pieces deemed in breach of those regulations. ${ }^{48}$ Seeking to extend the preservation of public decency to the auditorium, licensed managers permitting 'lewd or disorderly conduct' to go unchecked, or allowing the assembly of 'any common prostitutes or persons of notoriously bad character', were liable for a $£ 20$ fine in addition to the potential suspension of their license. ${ }^{49}$ To ensure these measures were respected, police were granted free access to any licensed venue..$^{50}$

\footnotetext{
${ }^{43}$ Licensed Theatres' Ordinance, 1862, Otago Provincial Government.

44 ibid, s.2.

${ }^{45}$ Thomas, p.96; Licensed Theatres' Ordinance, 1862, Otago Provincial Government.

${ }^{46}$ Licensed Theatres' Ordinance, 1862, Otago Provincial Government, s.6.

47 ibid, s.5.

48 ibid, s.5-6.

49 ibid, s.7.

50 ibid, s.8.
} 
Lawmakers recognised that theatres, as secular spaces open to the public at late hours where alcohol was consumed and emotions heightened, could be conducive to crime. Introducing provisions for preventing the assembly of 'persons of bad character', the legislation and its proponents also addressed the classist and moralistic objections raised by opponents of public theatrical amusements. The perceived corrupting influence of female immorality shaped overall attempts at moral preservation, with the prohibition of assembly of 'any common prostitutes' underscoring the continued, and threatening, association between playhouse and whorehouse in colonial society.

From a revenue standpoint, the ordinance was not especially lucrative. Theatrical appetites in Dunedin itself were well satisfied by the two professional playhouses, and smaller towns throughout Otago typically made do with irregular visits from touring companies. In 1863, theatre licenses contributed just $£ 25$ to the provincial coffers, compared with $£ 1280$ for publicans and $£ 166$ for auctioneers. ${ }^{51}$ A gradual rise in revenue, however, indicates the steady growth of theatre throughout Otago in the following years. In the half-year from April to September 1864, theatre license revenue increased to $£ 30$, before more than doubling to $£ 65$ for the same period in $1865 .{ }^{52}$

Attempts were made to enforce the new regulations. At least two groups of performers faced charges for breaching the stipulations of the Ordinance during the 1860s though neither case resulted in a conviction. Edward Lyons, proprietor of the Corinthian Hotel, successfully argued against a charge that he had staged a theatrical entertainment without a license by noting that, while a performance had taken place and money had been taken at the door, the character of the entertainment did not satisfy the established requirements for licensing. ${ }^{53}$ Similarly, in 1869, the Gourlay family successfully argued that the entertainment they had performed at Dunedin's Masonic Hall was 'not considered a stage, but a drawing room one. ${ }^{54}$ Dismissal of these cases, among others, raised questions about the uneven operation of the Ordinance and left managers of venues subject to the paid license requirements grumbling about their additional expenditure.

Louis Court, new manager of the Princess Theatre, filed a petition of complaint with the Provincial Government in 1869, arguing that the Princess, as a permanent establishment, was disadvantaged in comparison with visiting entertainers. ${ }^{55}$ Court, who paid license fees of $£ 60$ per year on top of $5 \mathrm{~s}$ a night for the services of policemen, expended more capital than those who visited the region only fleetingly to reap profits which they then invested elsewhere. ${ }^{56}$ Considering his petition in 1870, the Provincial Council concluded that Court had just grounds to complain and proposed an

\footnotetext{
${ }^{51}$ Otago Provincial Government Gazette, Vol. vi, no. 280, 1863, p.562.

52 Otago Provincial Government Gazette, Vol. viii, no. 330, 1864, p.110; Otago Provincial Government Gazette, vol. xi, no. 391, 1865, p.233.

53 ODT, 1 May 1868, p.5.

${ }^{54}$ ODT, 12 May 1869, p.5.

55 'Petition - Louis Court (1): For redress over partial operation of Licensed Theatres Ordinance - 13 May 1869', 1869, Otago Provincial Council Papers, Ref: R19002521, Dunedin, ANZ; 'Select Committee - Private Petitions: Interim Report No 4 on Petition of Louis Court - 18 May 1869', 1869, Otago Provincial Council Papers, Ref: R19002484, Dunedin, ANZ.

56 ODT, 5 May 1870, p.2.
} 
amendment to the original legislation which encompassed a wider range of entertainments staged in both permanent and temporary venues.

Not all agreed with the proposed changes. T. L Shepherd, member for the goldfields, noted that the 1862 ordinance had ultimately given 'protection to one particular party' and appeared to be 'calculated to suppress legitimate speculation' of touring entertainments 'regarded by many persons as far more enjoyable. ${ }^{57} \mathrm{He}$ argued that introducing licensing fees for all entertainments would have "the effect of abolishing amusements which had been much appreciated by the citizens, and which many persons residing in the country districts came to Dunedin to witness.' Extension of requirements for licensing fees, Shepherd argued, would dissuade this class of travelling entertainer from visiting Dunedin, ultimately injuring the city 'not only as regarded amusements, but in a pecuniary point of view.' 58

J. Hughes, member for Lawrence, voiced similar concerns and highlighted the detrimental effect the proposed amendments would have on entertainments for charitable purposes which, often organised by women, were generally to be encouraged. With particularly fervent opposition, Mataura representative W. A. Mosely branded the proposed amendment a 'most tyrannical piece of legislation. ${ }^{59}$ Addressing the deficiencies of both existing and proposed regulations, C. E. Haughton, member for Lakes, argued that the ordinance threatened the diversity of entertainment on offer, suppressing entertainments 'of a beneficial character, but which would only draw good houses for perhaps three or four nights. ${ }^{60}$ Others supported Haughton's claims, arguing that the ordinance ultimately 'prohibited a class of entertainment which were healthful' and 'agreeable to a very large and respectable portion of the community. ${ }^{61}$

The initial Amendment was rejected by 18 to 8 . Later that month, however, a follow-up petition from John Sibbald requesting an exemption for the Princess Theatre raised the issue again. ${ }^{62}$ Discussion of Sibbald's grievance left the Provincial Council pondering complete repeal of the 1862 Ordinance on the grounds that its uneven operation detrimentally affected certain venues. However, concluding that such a course of action would endanger 'public safety and public morals', they reached a compromise and introduced single night licenses for $5 \mathrm{~s}$, occasionally excepting 'entertainments given for the benefit of public institutions. ${ }^{63}$ The 1870 Amendment Ordinance also extended the definition of entertainment to include several new forms. Burlesque, which had become a particularly popular genre was included

\footnotetext{
57 ibid.

58 ibid.

59 ibid.

60 ibid.

61 ibid.

62 'Petition - John Sibbald (1): That the Princess Theatre may be exempted from Licensed Theatres Ordinance 1862 - 13 May 1870’, 1870, Otago Provincial Council Papers, Ref: R19002729, Dunedin, ANZ.

${ }^{63}$ Evening Star (Dunedin), 27 May 1870, p.2.
} 
for the first time. So too was 'that kind of entertainment known as the drawing-room entertainment' which, as Gourlay had successfully argued, was not covered by the previous regulations. ${ }^{64}$

\section{Rational Amusement}

The extent to which repertoire influenced audience composition was a common topic of discussion among those seeking to assert theatre's respectability. ${ }^{65}$ 'Higher class' entertainment attracted a more reputable crowd. Those emphasising the civilizing effects of dramatic entertainment faced staunch opposition from critics arguing that theatre degraded the moral health of society. The brand of entertainment on offer was regularly used to justify arguments for one side or the other and a hierarchical structure of social acceptance, which positioned crass variety entertainments against the high cultural experience afforded by opera and legitimate drama, came to dominate popular discourse. The contrasting reputations of different genres meant that theatre, as a whole, was viewed as morally ambiguous throughout the wider Anglo-world as opponents conflated refined legitimate dramas with sensation melodrama and riotous burlesque.

In addition to extending state control over playhouses, Walpole's 1737 Licensing Act constructed divisions between 'legitimate' spoken-word drama, performed in patent playhouses, and the 'illegitimate' forms entertaining audiences in non-patent venues. Granted exclusive rights to stage legitimate amusement, the Theatres Royal Drury Lane and Covent Garden dominated 'rational theatre' for the next century and the likes of Shakespeare and Sheridan became closely associated with the West End venues. Non-patent theatres, emerging in increasing numbers to cater to a vast array of new theatregoers and seeking to sidestep their exclusion from staging spoken-word drama, successfully petitioned for the right to produce plays with a musical element. ${ }^{66}$ Reaching a wider and more diverse audience, burlettas, melodramas, and extravaganzas produced by non-patent establishments became highly popular. Theatre in Britain was thus divided into legitimate entertainment associated with the refined theatregoing population of London's West End, and vastly more popular illegitimate forms entertaining audiences further afield who were prejudicially presented as rowdy, disreputable, and outright criminal. Legitimate drama was designed to educate, refine and civilize. Illegitimate forms, by contrast, catered to an unruly populace merely seeking leisure and cheap amusement.

While legitimate drama retained its reputation as the civilized pinnacle of English dramatics it was by no means the most popular entertainment on offer. Even once other playhouses obtained the right to produce legitimate works in 1843, illegitimate forms continued to prove more lucrative. As Richard Schoch has argued, 'a theatre's illegitimate, but vastly more popular offerings effectively

\footnotetext{
${ }^{64}$ Licensed Theatres' Ordinance, 1870, Otago Provincial Government; Otago Provincial Government Gazette, Session XVII, no.310.

${ }^{65}$ Davis and Emeljanow, pp.93-108; Phillips, pp.195-213.

${ }^{66}$ Thomas, p.104.
} 
subsidised its moral obligation to produce Shakespeare. ${ }^{67}$ Some theatres dismissed this 'moral obligation' entirely. In her analysis of the economics of British theatre, Tracy Davis argues that managers, on the whole, 'operated in their own self-interest, and not for the greater glory of dramatic literature, theatre aesthetics, or proletarian culture. ${ }^{68}$ Whatever ambitions they may have harboured to cultivate an appreciation for rational amusement, managers' personal finances took precedence. The same was true in New Zealand. While several managers set out to stage legitimate dramas and promote the respectability of their establishments, when this proved unprofitable many turned to 'inferior' brands of amusement to line their pocketbooks.

Arriving in Dunedin in 1862, Clarance Holt reported feeling a certain social duty in designing his programme. 'In a colony like New Zealand', he noted, 'I shall endeavour most strenuously to keep up the tone of the theatre, and uphold the dignity of our art. ${ }^{69}$ Holt intended to offer only legitimate amusement, believing it would be 'unwise' to introduce popular melodrama and other 'low entertainment' into the company repertoire. ${ }^{70}$ Shortly after opening, however, it became apparent that a second playhouse, the Princess Theatre owned by Shadrach Jones, was hampering Holt's profits. 'The prices were low and the entertainment, although of an inferior quality to what we were giving, attracted a vast number of persons who would otherwise have supported us', Holt noted. ${ }^{71}$ Success of the rival establishment posed a significant threat 'owing to the smallness of their expenses and their low prices of admission.' The programme designed by managers Tom and Sandford Fawcett proved incredibly popular and, while both theatres struggled with the limited constituency of theatregoers, Holt and his business partner James Le Roy soon swapped their refined programme for a more spectacular bill, staging back to back seasons of Boucicault's famed sensation dramas The Colleen Bawn and The Octoroon.

Peter Kuch argues that managers in colonial society utilised legitimate drama to promote theatre as a source of civic improvement. ${ }^{72}$ While the benefits of legitimate drama were certainly emphasised by the press, many managers like Holt and Le Roy found that such pieces did not so effectively cater to public taste. Reference to the legitimate fare on offer at local venues was regularly accompanied by comment that such a programme should have been better patronised than it was. Despite this fact, legitimate drama was still consistently promoted as the most civilized and intelligent form of amusement. With the opening of the new Theatre Royal in Auckland in 1856, for example, the Daily Southern Cross noted that the proprietors' apparent lean toward legitimate forms was one which 'in a community so generally intelligent' as that of Auckland was 'the course that must, ultimately, be the

\footnotetext{
${ }^{67}$ Schoch, p.332.

${ }^{68}$ Davis, Economics of the British Stage, p.4.

${ }^{69}$ Clarance Holt, 'Twice Around the World or Recollections of an Old Actor', Ref: MS0224/2/1, NLA, p. 372.

70 ibid.

${ }^{71}$ ibid, pp.375-376.

${ }^{72}$ Peter Kuch, 'Irish Playwrights and the Dunedin Stage in 1862: Theatre Patrons Performing Civility', Journal of New Zealand Studies, no.15, 2013, p.90.
} 
successful one. ${ }^{73}$ The following year, local theatregoer David Burn sought to direct the Royal back on course when he declared that, having witnessed 'a poor house and still poorer performance', the management could not 'hope to prosper so long as they continue[d] to play nothing but melodramas of the worst class. ${ }^{74}$

Similar sentiment was expressed in Greymouth in 1867 where Union Hotel proprietor Joseph Kilgour had 'always evinced a ready desire to provide first class entertainment. ${ }^{75}$ Despite engaging a 'really excellent company', meagre houses led the press to intervene. 'We would urge the public to encourage Mr Kilgour in his efforts to provide them with legitimate recreation', the Grey River Argus declared, 'and not let it be said that a deserving company cannot find appreciation in a town like Greymouth. ${ }^{76}$ In Hokitika, James Bartlett had also been praised for his legitimate programmes. His opening season was popular with local critics. The West Coast Times reported in June 1866 that the theatre was 'a public boon', providing entertainments 'of the highest class, such as are offered to the audiences of the first-class theatres of London, and other great English towns. ${ }^{77}$

Those emphasising the social benefits of the stage also placed significant emphasis on the production of legitimate drama. Having witnessed the growing popularity of the playhouses in 1862, the editors of the Otago Daily Times noted that theatre offered 'one of the most valuable means of public education' especially when managers provided 'as high a class of entertainment, as the general character of the audience render[ed] possible. ${ }^{78}$ In addition, support for tours of the likes of Lyster's Opera Company illustrates the extent to which 'high culture' was privileged and created by popular perceptions of respectability. Evidently attracting a more sophisticated class of playgoer, Lyster's Company transformed the Princess Theatre into 'quite a picture of gaiety' with a dress circle, the press noted, which was populated by those who enabled it to finally live up to its name. ${ }^{79}$ Recognition that such a programme attracted a more civilized audience than melodrama and farce emphasises the perceived social consequences of legitimate theatre divisions which permeated colonial society.

\footnotetext{
${ }^{73}$ DSC, 11 March 1856, p.3.

${ }^{74}$ David Burn, 'David Burn Diary, 10 October 1855 - 15 September 1858', Microfilm: CY 1094, Ref: 844931, Mitchell Library, Sydney.

${ }^{75}$ GRA, 23 February 1867, p.2.

${ }^{76} G R A, 26$ September 1867, p.2.

${ }^{77}$ WCT, 16 June 1866, p.6.

${ }^{78}$ ODT, 24 August 1864, p.4.

${ }^{79}$ North Otago Times, 15 September 1864, p.3.
} 


\section{Legitimate Theatre in Garrison Locations c.1850-1859}
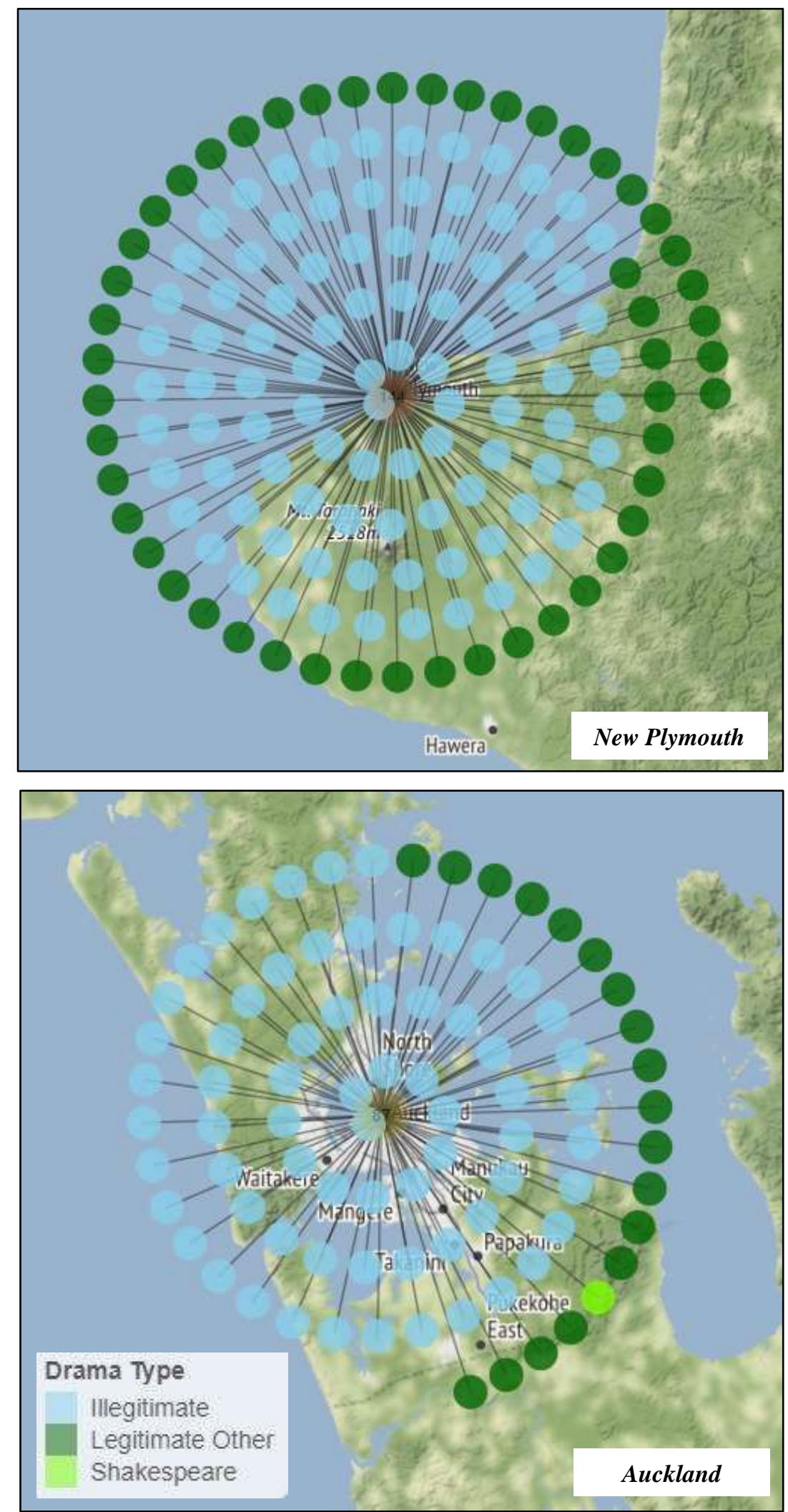

Figure 4.1: Legitimate vs illegitimate drama in garrison locations. Illegitimate forms (mapped in blue) dominated garrison repertoire while Shakespeare (lime green) was not common. Full map: www.entertainingprospects.weebly.com/maps1.html 


\section{Legitimate Theatre in Smaller Gold Town Locations c.1860-1869}
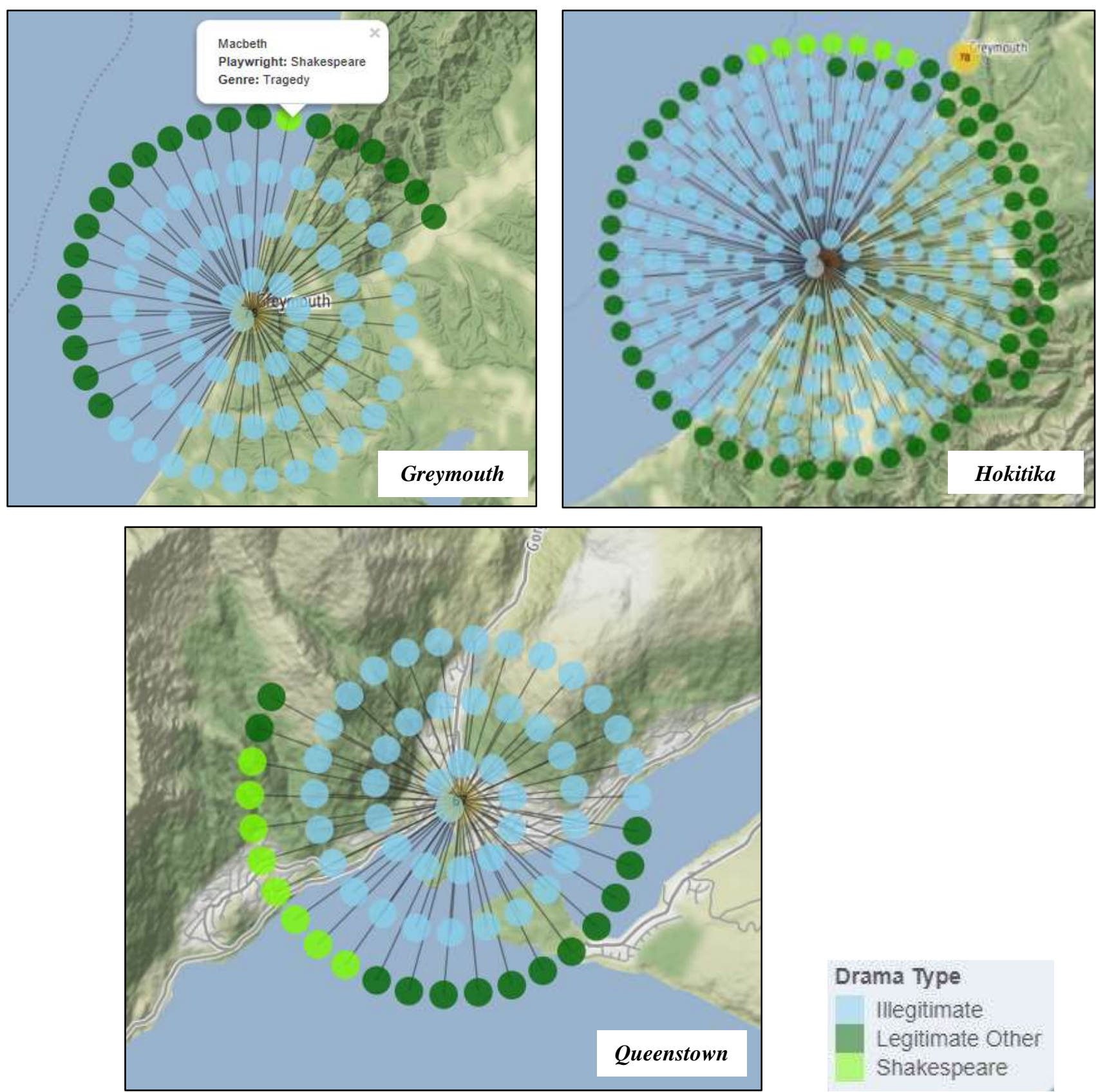

Drama Type

Illegitimate

Legitimate Other

Shakespeare

Figure 4.2: Legitimate vs illegitimate drama in gold town locations. Illegitimate forms (blue) dominated entertainment, although more legitimate repertoire, particularly Shakespeare (lime green), enjoyed greater popularity. Full map: www.entertainingprospects.weebly.com/maps 1.html 
The performance and appreciation of legitimate entertainment may have helped to construct an image of cultivated and respectable society, but popular illegitimate genres continued to prove more lucrative. Most theatregoers in goldrush Otago and along the West Coast sought entertainment first and foremost, and illegitimate fare was generally more amusing and attractive to patrons. Novelty significantly enhanced patronage, as indicated by analysis of the success or otherwise of various theatre managers, and illegitimate productions - packed with spectacle, music, and vibrant colour - were intrinsically more novel. Stuart O'Brien found that there was not 'much present inkling to the more solid legitimate drama' and only succeeded in attracting moderate houses after taking the reins at the Princess in the wake of the feast of 'light, sparkling and laughable' pieces performed under Lady Don's direction. ${ }^{80}$ Joey Gougenheim, conversely, facilitated an uptick in attendance by shifting from Rosa Cooper's programme of heavy dramas to one dominated by 'ballet, pantomime, and the flying trapeze. ${ }^{81}$

Analysis of the performance data compiled for New Plymouth, Auckland, Hokitika, Greymouth, and Queenstown reveals that illegitimate genres dominated repertoire across the board (figures $4.1 \& 4.2$ ). Shakespeare, a marker of cultural sophistication, was staged occasionally by gold town managers. However, very few performances of this kind were rendered by military amateurs. In April 1850, a report in the Daily Southern Cross discussed the utility of military theatre as a leisure occupation. ${ }^{82}$ It had always been, the writer noted, viewed as 'judicious practice' to 'ameliorate the soldiers' comfort and condition by every prudent and possible concession' and to 'encourage every rational measure calculated to soften the toils of duty and to attach the men to the service. ${ }^{183}$ Amateur theatricals offered one means to 'beguile the irksomeness of a garrison life. ${ }^{84}$ As such, while the amusement was kept strictly proper, theatre's primary purpose in these settings was to alleviate the monotony of everyday life rather than cultivate ambitions of moral and social refinement. Repertoire focused on self-improvement was largely dominated by more spectacular or amusing productions (figures $4.3 \& 4.4$ ).

Of the 149 productions staged by military amateurs of the $65^{\text {th }}$ regiment stationed at Marsland Hill in New Plymouth between 1857 and 1861, the vast majority were popular farces and melodramas. Burlesques, popular with gold town audiences in the 1860 s, were comparatively sparse. Just three short burlettas were staged in military theatres, all of which were performed by the amateurs stationed at Marsland Hill. At the other end of the spectrum, no attempt was made to stage any works of Shakespeare in Taranaki. In Auckland, just one production of Katherine and Petruchio, David Garrick's adaptation of Shakespeare's The Taming of the Shrew, represented any attempt to introduce Shakespearean works into the wider programme. The fact that many performances in these locations were benefits for

\footnotetext{
${ }^{80} O D T, 11$ May 1866, p.4.

${ }^{81}$ ODT, 24 April 1865, p.4.

${ }^{82}$ DSC, 9 April 1850, p.2.

83 ibid.

${ }^{84}$ ibid.
} 
charitable causes may have influenced the repertoire on offer. Farces and melodramas attracted larger audiences, and thus promised a better economic return.

In the gold towns of the south, a similar trend was observed. In Greymouth, where Joseph Kilgour was praised for offering high class entertainment, just one of seventy-eight performances was Shakespearean, a production of Macbeth staged in July 1867. In Hokitika, a little larger than its West Coast companion, seven productions of the Bard's works were performed between 1866 and 1869, five of which were produced shortly after Bartlett's Prince of Wales Opera House opened in 1866. Queenstown, with Tom Fawcett's short venture in 1863-64, offered the largest proportion of Shakespeare performances, with eight out of sixty-seven, including four renditions of Othello. A shift away from including Shakespeare as a means of promoting respectability was not restricted to garrison and gold town theatres. In Wellington, for example, the programmes of several seasons between 1850 and 1867 across various venues included just eleven works of Shakespeare, including four performances of Macbeth.

High rates of production of farce and more sophisticated dramas and comedies held true across theatres in both garrison and gold towns. In the garrison settlements, melodrama was also popular and, in fact, surpassed comedy at the Albert Barracks in Auckland. In Dunedin, burlesque emerged as a prominent genre, with more than 160 performances staged between 1862 and 1869 . Work by Henry Byron proved particularly popular. His adaptation of Aladdin enjoyed successful seasons in 1862 and 1865, and Cinderella entertained audiences at the Princess Theatre from October to December 1862 before returning for shorter seasons in 1863 and 1867. The genre was also popular with Hokitika audiences, partly, perhaps, due to the strong links with playhouses in Dunedin forged by the movement of thespians and gold-seekers.

In most cases, theatre managers made a concerted effort to highlight the respectability of their repertoire to promote the overall moral and social benefits of theatre as a whole. While opponents continued to criticise the theatres as houses of disorder and degradation, much of the fare on offer was utilised by the press and their correspondents to emphasise the public benefit which could be accrued from properly managed venues. Staging and attending legitimate dramas continued to be promoted as a form of social refinement, bested only by opera which surpassed all other dramatic forms when it came to promoting societal civility and appreciation for high culture. Theatrical divisions in repertoire, and their corresponding social implications, largely mirrored those of the British metropole. The limited number of theatre venues, however, meant that whilst in Britain such distinctions could be demarcated in public space with different theatres offering distinct brands of entertainment and thereby appealing to a specific clientele, such distinction was not possible in New Zealand. Many venues staged entertainments from across the theatrical spectrum, and the relative success of different genres played a significant role in shaping the subsequent repertoire on offer. 


\section{Auckland (Albert Barracks) Performances by Genre 1851-1858}

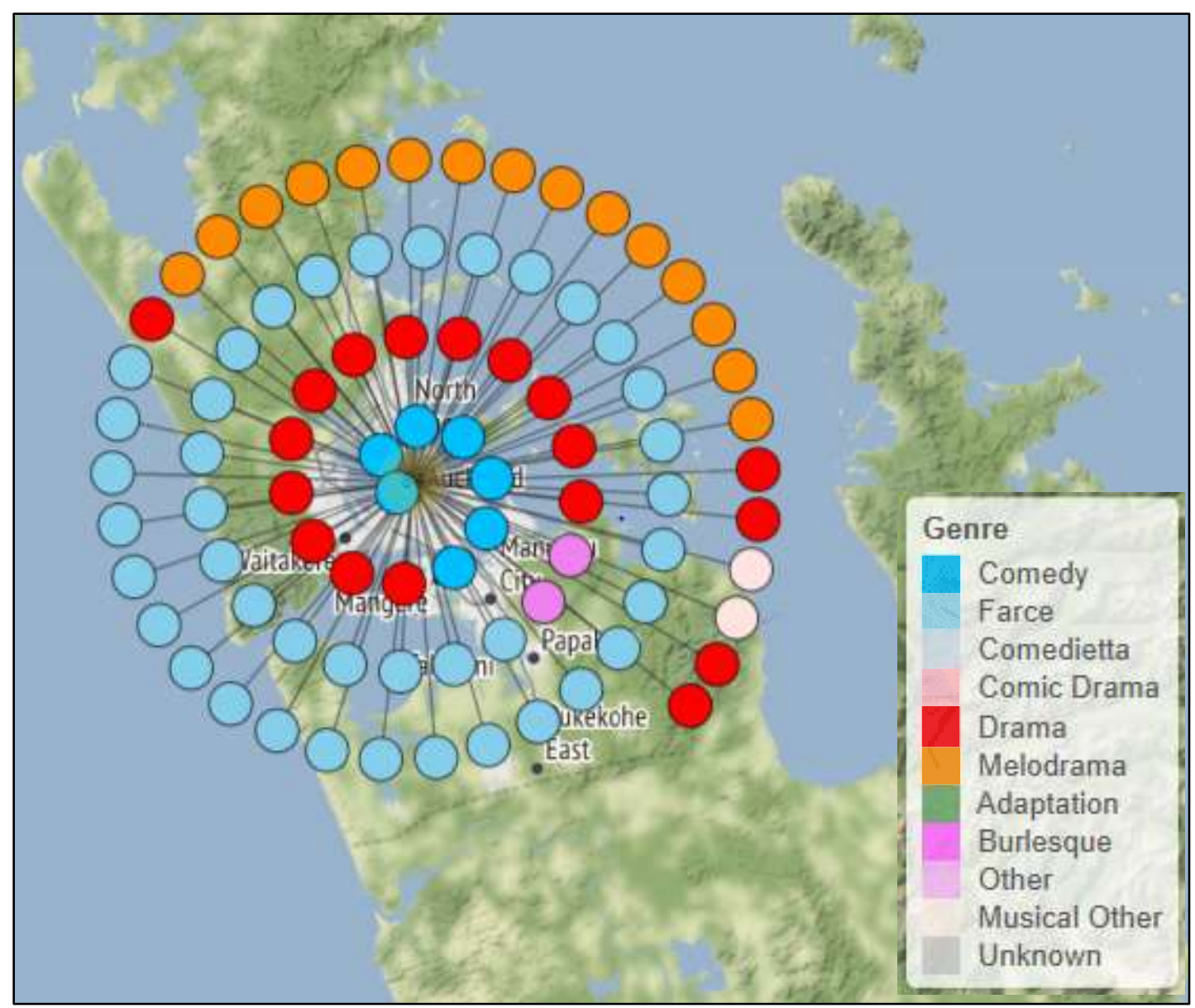

Figure 4.3: Genre Analysis: Auckland. Eighty-four performances were staged by military amateurs at Albert Barracks between 1851 and 1858. Farce and drama were the most popular genres, followed by a significant number of shorter melodramas. Charles Selby was the most popular playwright, followed by John Baldwin Buckstone and James Maddison Morton. The programme was dominated by English playwrights, who accounted for a study high of 85 per cent of productions. Full map: www.entertainingprospects.weebly.com/maps1.html 


\section{New Plymouth (Marsland Hill) Performances by Genre 1857 - 1861}

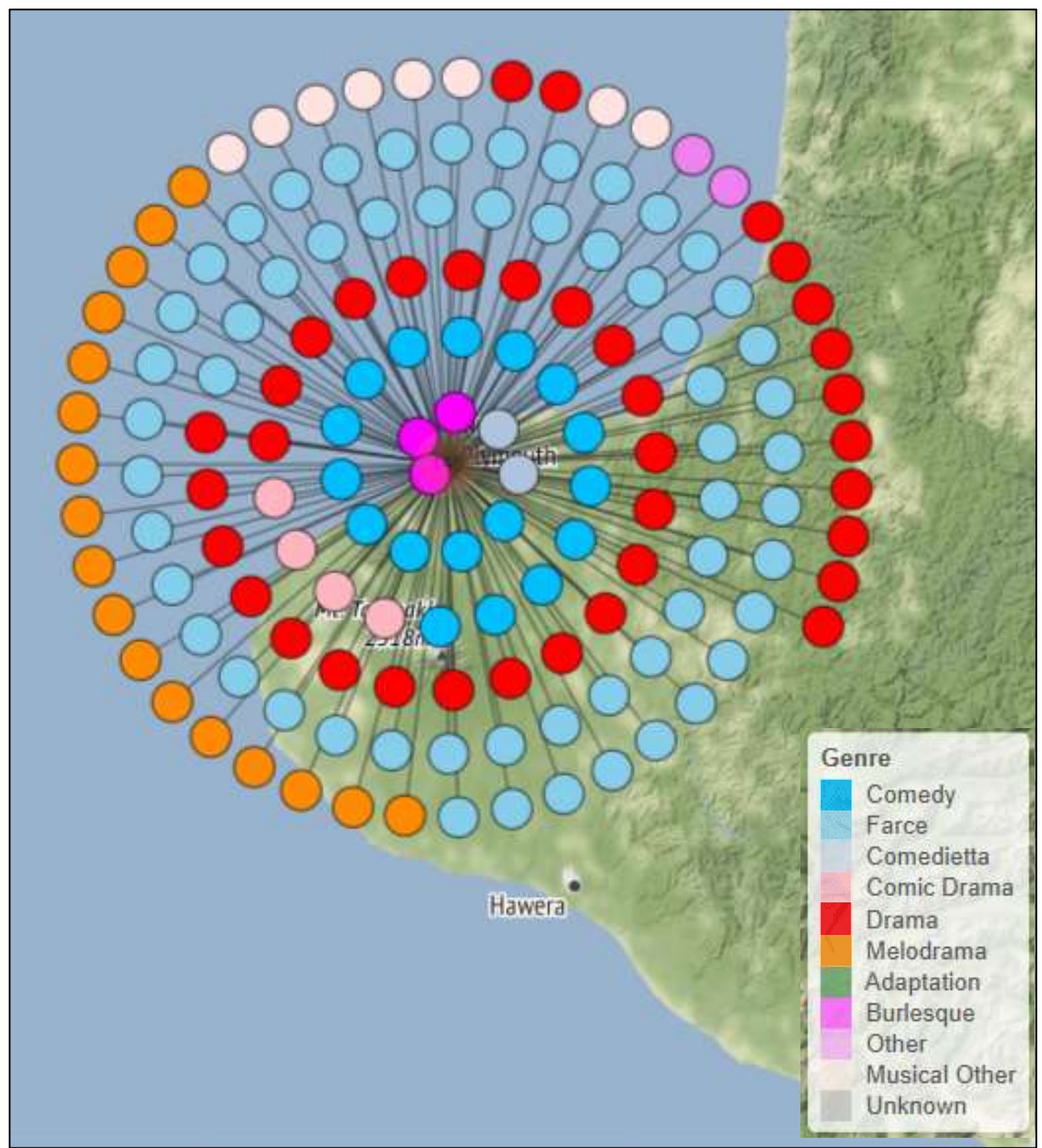

Figure 4.4: Genre Analysis: New Plymouth. One hundred and forty-nine performances were staged at Marsland Hill between 1857 and 1861. Like Auckland, farce, drama and melodrama were the most popular genres. Melodramas such as Buckstone's Luke the Labourer and John Thomas Haines' The Idiot Witness entertained audiences during 1857. Selby and Buckstone were the most performed playwrights in New Plymouth, and English work dominated the programme - accounting for 80 per cent of performances. Full map: www.entertainingprospects.weebly.com/maps1.html 


\section{Queenstown Performances by Genre 1863-1864}

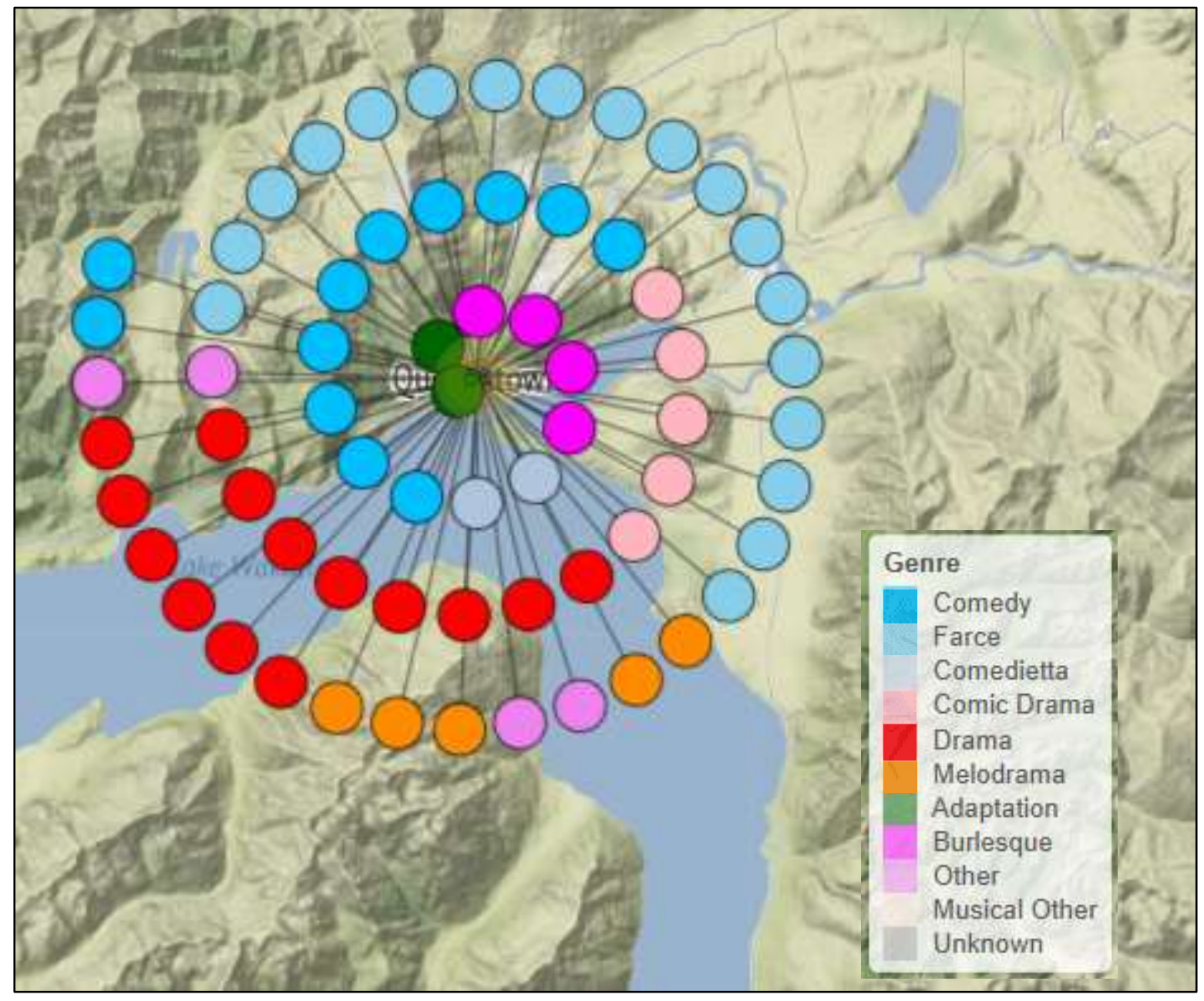

Figure 4.5: Genre Analysis: Queenstown. Sixty-six performances were staged in Queenstown between 1863 and 1864. Farce and serious drama were the most popular genres. Buckstone and William Shakespeare were the most performed playwrights, and the proportion of Shakespeare performances far exceeded the study average. English playwrights dominated, accounting for 54 of the 66 performances. Full map:

www.entertainingprospects.weebly.com/maps1.html 


\section{Hokitika Performances by Genre 1866-1869}

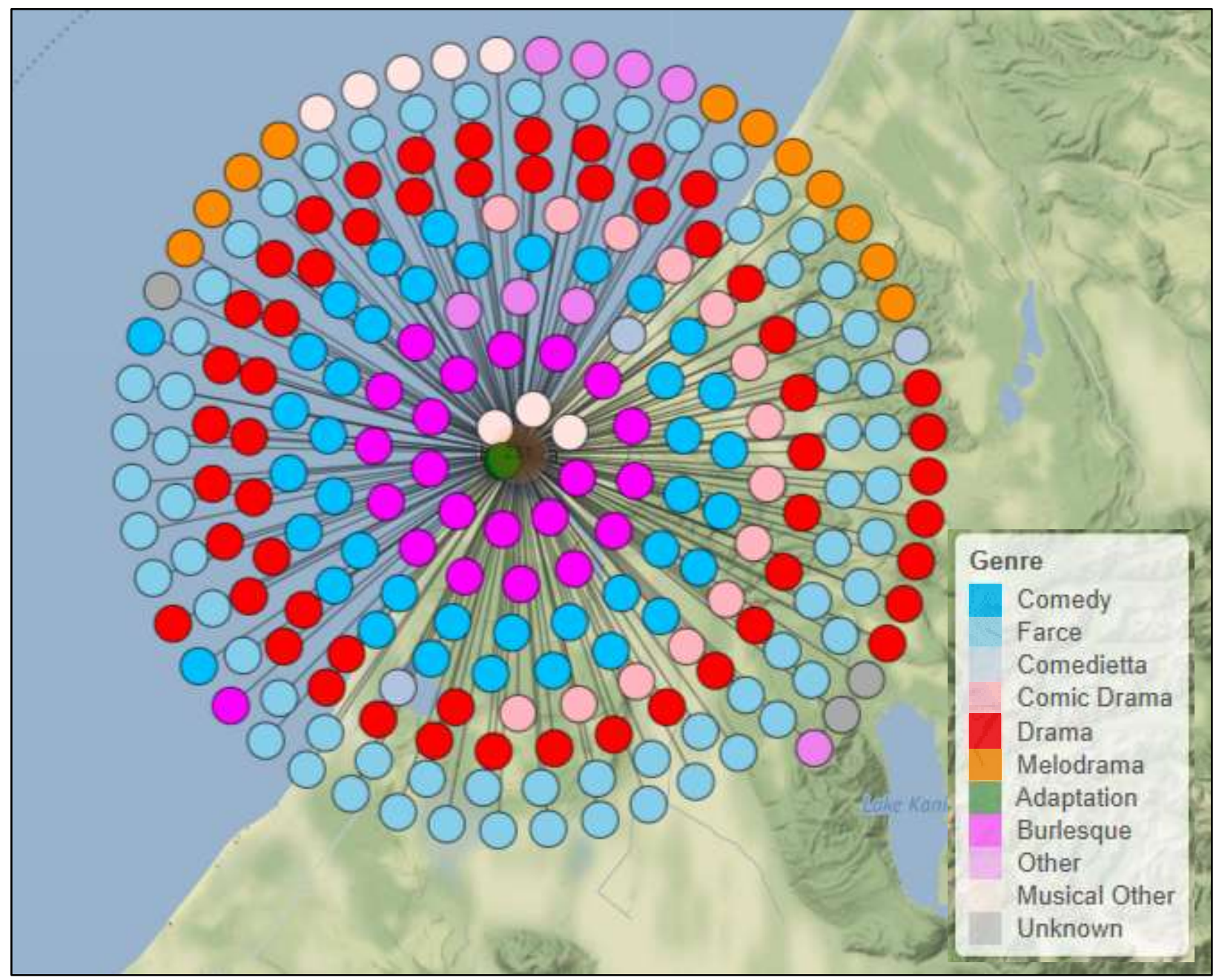

Figure 4.6: Genre Analysis: Hokitika. Two hundred and thirty-one performances were staged in Hokitika between 1866 and 1869. Farce was the most popular genre, followed by drama, comedy, and burlesque. Dion Boucicault was the most performed playwright. The Coriscan Brothers (1852) was performed three times during the inaugural season at the Prince of Wales Opera House. Farces by Buckstone and Morton were also popular. Morton's Box and Cox was performed five times as was Buckstone's The Rough Diamond. While English pieces remained dominant, work by Irish playwrights enjoyed particular success in Hokitika, accounting for 21 per cent of plays compared with the study average of 12 per cent. American playwrights were also better represented, with 9 per cent of performances compared with the study average of 5 per cent. Full map: www.entertainingprospects.weebly.com/maps1.html 


\section{Greymouth Performances by Genre 1866-1868}

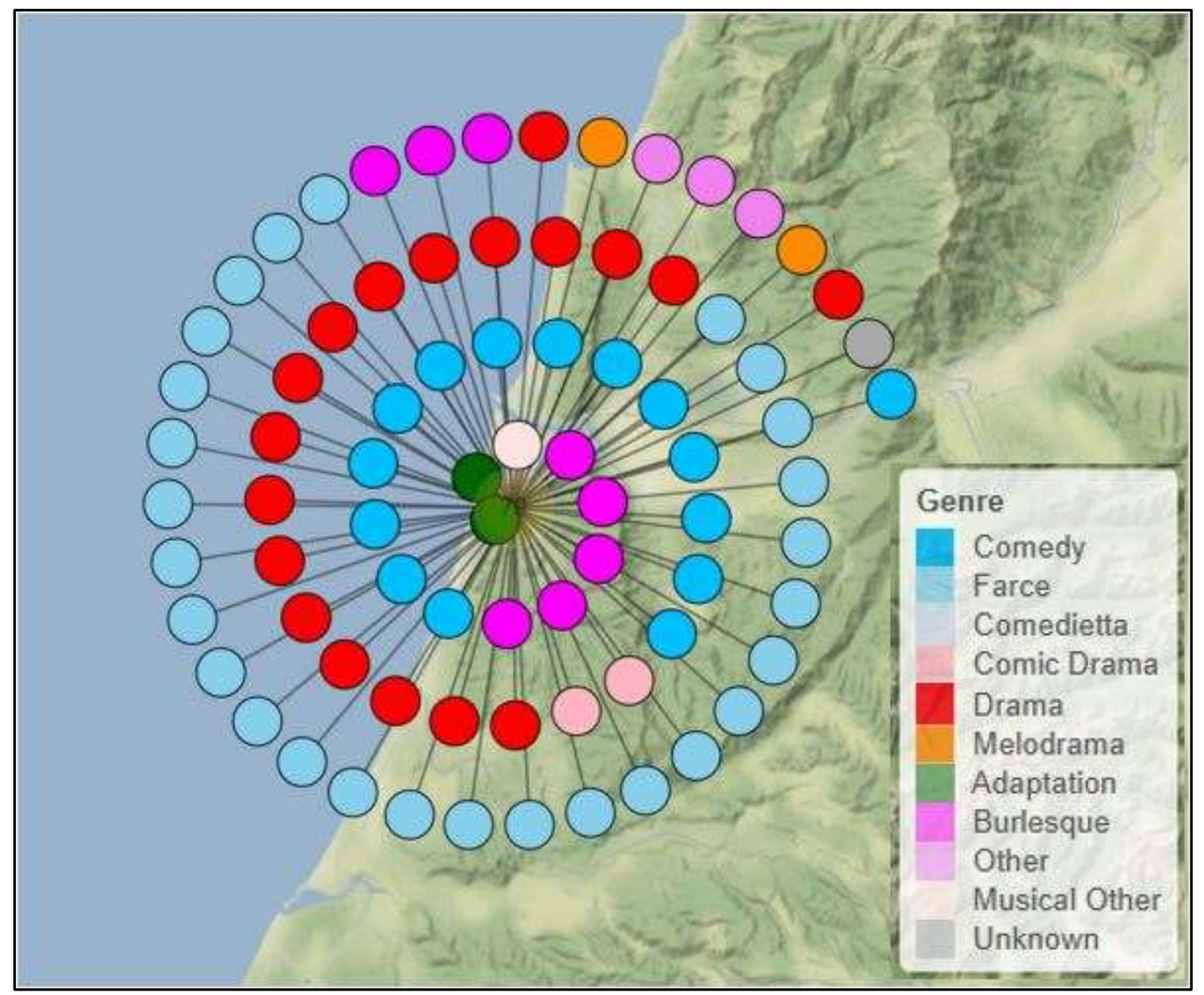

Figure 4.7: Genre Analysis: Greymouth. Seventy-nine performances were staged in Greymouth between 1866 and 1868. Farce, drama, and comedy were the most popular genres, followed burlesque. Boucicault also enjoyed success in Greymouth, joined by fellow Irish playwright Tyrone Power. Power's The Omnibus was staged five times, and Boucicault's Andy Blake was also popular. However, English-born Selby, a favourite with garrison audiences, claimed the most performances in Greymouth with farces Boots at the Swan, The Bonnie Fish Wife, and The Widow's Victim all performed between 1866 and 1868. English playwrights remained predominant, but their proportion of productions dropped to a study low of 59 per cent. Americans enjoyed more success, accounting for 11 per cent of the total compared with the study average of 5 per cent. Full map: www.entertainingprospects.weebly.com/maps1.html 


\section{Respectable Patrons and Venues}

The desire to attract respectable patrons drove many managers' promotional efforts, informing both repertoire selection and the enforcement of particular codes of conduct within the auditorium. Despite permeating all aspects of life during the Victorian period, the proper performance of respectability was contested and often contradictory. In fact, Richard Schoch notes, quite what mid-Victorians meant by 'respectability' was 'always a bit unclear, even to them. ${ }^{85}$ There were, however, several consistent attributes which characterised the British middle-class definition of respectable conduct. Cleanliness and hard work coupled with self-sufficiency, thrift, piety, and correct speech were, Schoch argues, among those 'few social attributes' which 'figured in nearly all accounts of respectable behaviour. 86

The conception of cleanliness as a precursor to respectability had some impact on theatre criticism in New Zealand. Speculating on the propriety of Bartlett's Prince of Wales Opera House in 1866, the West Coast Times suggested that the manager would do well to ensure that those entering the dress circle had, among other things, 'become acquainted with soap at least once within the previous six months. ${ }^{87}$ Such a suggestion was, perhaps, more literal for theatregoers in goldrush Hokitika than those attending the Theatre Royal Covent Garden. Nonetheless, the implementation of Victorian standards of cleanliness - both morally and physically - heavily imbued with a moralistic critique of existing theatre audiences, demonstrates the extent to which the theatre, as a site of social amusement, was expected to impart and uphold a standard of respectable behaviour.

Dress, gender, and seating patterns also informed contemporary impressions of audience propriety. The Otago Daily Times, lamenting a degradation in the general class of Princess Theatre patrons in October 1863, recalled that it had previously been 'somewhat the fashion for ladies to appear in full dress' adding that it was pleasing 'to see so numerous a muster of the fair sex' in the private boxes and dress circle to witness Julia Mathews' debut. ${ }^{88}$ While female performers and managers were often treated with suspicion and criticised for their lack of adherence to traditional gendered hierarchies, female patrons, generally, experienced the opposite. Women, particularly well-mannered middle-class women, were the epitome of the civilized playgoer. As a result, any habits or programmes which dissuaded them from attending were critiqued for their lack of respectability.

In Invercargill, commentators for the Southland Times critiqued the settlement's existing entertainment venues as degraded haunts of 'roystering bachelors' which 'ladies at any rate would not care to affect. ${ }^{99}$ To many, developments intended to attract a 'respectable' class of audience were synonymous with those appealing directly to women. Even in garrison locations, the ability to appeal to female theatregoers was interpreted as a marker of respectable entertainment. Following the opening

\footnotetext{
${ }^{85}$ Schoch, p.331.

86 ibid.

${ }^{87}$ WCT, 27 August 1866, p.2.

${ }^{88}$ ODT, 27 October 1863, p.5.

${ }^{89}$ Southland Times, 28 September 1863, p.2.
} 
performance at the Royal Military Theatre in Marsland Hill, for example, the Taranaki Herald advised that 'a less frequent use of oaths and flash expressions [would] increase the enjoyment of the ladies, and ensure more extensive patronage by the respectable classes. ${ }^{90}$ Offstage, venues allowing patrons to smoke in the auditorium were criticised for the detrimental effect that the resulting clouds of tobacco smoke had on the comfort of fellow theatregoers. Fearing that permitting smoking would dissuade respectable patrons from attending, many managers went to some effort to curb the practice. In Hokitika, James Bartlett's enforcement of the smoking ban in his venue 'to which ladies [were] invited', was applauded by those hoping to cultivate a sophisticated theatregoing public. ${ }^{91}$

Audience behaviour had a profound effect on the theatregoing experience and was thus noted by both patrons and critics. Reporting on an amateur performance in Auckland in 1858, John Rogan reserved his few lines of commentary for the audience rather than the action onstage. Attracting 'all the grandees of Auckland', including Colonel Wynyard, commanding officer of the $58^{\text {th }}$ regiment, Rogan lamented the increasingly boisterous behaviour of several attendees who 'became very noisy and rude' toward the end of the performance and caused 'the Elite to retreat before the play was over.' ${ }^{92}$ Performances at the garrison theatre in Auckland regularly attracted the patronage of the city's developing social elite. Colonel Wynyard was a regular patron and his attendance was noted by both the press and fellow theatregoers. ${ }^{93}$ Respectable audiences were expected to express their appreciation for a more sophisticated class of culture than that offered by the hotel dance or music hall but to do so in a way which kept pace with expectations of reserved emotional expression and public behaviour. Attracting the patronage of civilized members of society relied on ensuring the propriety of the remainder of the house.

By the late 1860s, the theatregoing public patronising Auckland's professional establishments no longer drew its strength from social elites. Writing to the editor of the Daily Southern Cross in 1868, 'Anthropos' noted the preponderance of the working and middle classes in the auditorium of the Prince of Wales Theatre:

When we find that the real supporters of the drama in this place are mainly to be found among the middle and working classes, and that the audiences drawn together nightly are principally composed of these classes - when we find such a play as Macbeth one of the greatest efforts of the genius of the great bard, put upon the stage in a manner that would do credit to any London theatre, and admirably sustained throughout by an able and efficient company, taken all in all, surely we can arrive at no other conclusion than in saying that, though the elite may know what good acting is, it is only the working and middle classes who really know how to appreciate it... ${ }^{94}$

\footnotetext{
${ }^{90} \mathrm{TH}, 10$ January 1857, p.2.

91 WCT, 29 August 1866, p.2.

${ }^{92}$ John Rogan to Donald McLean, 16 February 1858, Donald McLean Papers, Ref: MS-Papers-0032-0540,

ATL, https://paperspast.natlib.govt.nz/manuscripts/MCLEAN-1009392.2.1.

${ }^{93}$ David Burn, 'David Burn Diary, 10 October 1855 - 15 September 1858', Microfilm: CY 1094, Ref: 844931, Mitchell Library, Sydney; DSC, 19 September 1851, p.1; TH, 14 February 1857, p.3.

${ }^{94}$ DSC, 11 November 1868, p.4.
} 
A disreputable image could detrimentally impact the viability of colonial playhouses, a fact readily observed in theatre managers' concerted efforts to promote and maintain the respectability of their venues. Managers adhered to a particular set of social standards, implementing similar procedures or restrictions throughout the colony to preserve the propriety of their establishments. Taking the issue to the auditorium, managers went to significant lengths to ensure the comfort of their audience. The sensory experience of theatregoing was enthralling, but it could also be unpleasant. In Wellington in 1866, members of the local Garrick Club made a point of advertising that the theatre would be 'fumigated at intervals with Rimmell's Patent Vaporiser' which contained 'all the most delicious perfumes of the day. ${ }^{95}$ Further highlighting concerns about olfactory experience, the need for proper ventilation became a common topic of complaint among theatregoers. ${ }^{96}$

Prohibiting objectionable behaviours that impeded audience comfort played a large role in attracting a more respectable audience. Behaviour which could be reasonably expected and tolerated within the auditorium varied slightly according to the locality and stated purpose of the venue. There were, however, several complaints which emerged across the colony. Few habits attracted more criticism than smoking in the auditorium. At a practical level, the vast majority of colonial theatres were wooden structures, many of which adjoined hotels or public houses. The risk of fire was a common concern, and theatre proprietors took great pains to ensure procedures were in place to combat any incendiary crises. Nonetheless, several notable playhouses succumbed to the risk. Dunedin's Theatre Royal was destroyed in late 1867 when a fire consumed many businesses on Princes Street, and the Princess Theatre followed suit in $1875 .{ }^{97}$ While no official cause was ascertained for the latter, reports indicated that the demise of the settlement's first professional playhouse was initiated by a 'lighted match or tobacco' which had been smouldering next to the upstairs entrance to the dress circle. ${ }^{98}$

Colonial responses to smoking were gendered and significantly shaped by existing attitudes in Victorian Britain. Analysing the practice in the context of middle-class gentlemen's clubs, Alexandra Mitchell highlights the extent to which smoking acted both as recreation and marker of class. ${ }^{99}$ Different smoking habits became relevant symbols of class throughout the eighteenth and nineteenth centuries and the consumption of inferior tobacco was indicative of class position. ${ }^{100}$ Smoking was associated with vice throughout the early Victorian period, but by the latter half of the nineteenth century it had become an accepted pastime popular with men from all classes. ${ }^{101}$ Male social spaces, such as gentlemen's clubs, were given 'odour and visible shape' by tobacco smoke, and smoking as a leisure

\footnotetext{
${ }^{55}$ Evening Post, 27 April 1866, p.2.

${ }^{96} \mathrm{TH}, 14$ February 1857, p.3.

97 ODT, 2 April 1867, p.4; ODT, 30 August 1875, p.7.

98 ODT, 30 August 1875, p.7.

99 Alexandra Mitchell, 'Middle-Class Masculinity in Clubs and Associations: Manchester and Liverpool, 18001914', PhD thesis, University of Manchester, 2011.

${ }^{100}$ Rudy Jarrett, The Freedom to Smoke: Tobacco consumption and identity, (Montreal: McGill-Queen's University Press, 2005), p.6.

${ }^{101}$ Mitchell, p.230; Jarrett.
} 
activity constructed a distinct gendered divide. ${ }^{102}$ As a sociable activity, Mitchell argues, smoking formed 'an integral part of a masculine social world' and smoking rooms were typically characterised by the distinctive performance of bachelor masculinity. ${ }^{103}$ Smoking in the presence of women, however, remained bad form, and critics continued to argue that it was something to be 'practiced in inconvenient places and not too publicly. ${ }^{104}$ Women entering the tobacco-filled space of a gentlemen's smoking room, Rudy Jarrett argues, 'put their respectability into question.' 105

Smoking bans were discussed in distinctly moralistic terms by the press, who emphasised the detrimental influence smoking in the auditorium had on the respectability of the audience rather than on their physical health and safety. Bans were enforced on a case by case basis. ${ }^{106}$ However, by the 1860s, the practice was prohibited, to some degree, in most professional theatres throughout the colony. The threat to public morals was recognised by managers and patrons alike, with one letter to the editor of the Press noting that the prevalence of smoking in theatres in Christchurch discouraged many prospective patrons from attending:

I know that many persons will not go to our theatre, and other places of amusement, because of the unbearable whistling, smoking and other objectionable habits which are there indulged in without restraint...To my mind, liberty is the right to do what you please so long as you do nothing to annoy others, and I trust the police and the managers of such place will take measures to eject all who persist in these rowdy habits. A very few examples would end the disgusting practices. ${ }^{107}$

Seeking to assuage some of these fears, managers used smoking prohibitions to promote the propriety of their venues. In Wellington, advertisements assured prospective patrons that 'the strictest order and decorum' would be enforced 'and smoking strictly prohibited.' ${ }^{108}$ In August 1860, Wellington's Royal Olympic noted that the police would be in attendance 'to enforce strict propriety and prevent smoking. ${ }^{109}$

Despite their best efforts, the regularity with which smoking was debated in colonial theatre circles indicates that it was an ongoing problem for managers. The persistence of the nuisance at Auckland's Prince of Wales Theatre attracted press attention on several occasions throughout the $1860 \mathrm{~s}$ and early 1870s. Mention was first made in 1864, when theatre critics for the New Zealand Herald noted that the one fault of the venue was the fact that the smoking prohibition was not strictly

\footnotetext{
102 Jarrett, p.6.

${ }^{103}$ Mitchell, pp.211, 230; John Tosh, A Man's Place: Masculinity and the middle-class home in Victorian England, (New Haven: Yale University Press, 1999), p.187.

${ }^{104}$ G.L. Apperson, The Social History of Smoking, (London: Martin Secker, 1914), pp.156, 164.

105 Jarrett, p.6.

${ }^{106}$ New Zealand Spectator and Cook's Strait Guardian, 19 January 1850, p.2.

${ }^{107}$ Press (Christchurch), 7 June 1870, p.3.

${ }^{108}$ Wellington Independent, 9 March 1860, p.2.

${ }^{109}$ Wellington Independent, 7 August 1860, p.2.
} 
enforced. ${ }^{110}$ The issue was addressed again in May 1869, when it sparked the ire of the Daily Southern Cross:

How is it that the Auckland public are such Gothics and Vandals as to persist in smoking in the theatre? Notwithstanding the placards on the walls requesting them not to do so, every now and then clouds of smoke emerge from the denizens of the pit; and the efforts to suppress it, although no doubt vigilantly exercised, appear, up to the present, to be unavailing. ${ }^{111}$

Despite this condemnation, matters did not improve. In March 1870, the Auckland Star reported that Stuart O'Brien had intervened when smoking patrons would not desist by 'forcibly drawing attention to it from the stage.' ${ }^{112}$ O'Brien's attempt at putting 'a stop to the disgusting habit' was applauded by the Star correspondent but the issue re-arose several times in subsequent editorials. ${ }^{113}$

Even in theatres catering to gold town populations perceived to be both carefree and lawless, bans were put in place and actively advertised. In Hokitika, James Bartlett employed a strict smoking prohibition which set his Prince of Wales Opera House apart from the town's other entertainment venue, the City Theatre. The latter establishment, Philip May records, allowed 'unlimited smoking and drinking...during the performance', the result being that 'people in the upstairs boxes almost suffocated. ${ }^{114}$ At the Prince of Wales, Bartlett's ban was effective in shaping his desired audience. One West Coast Times commentary noted:

The regulation of the management prohibiting smoking in any part of the house, was last night rigidly enforced. It would perhaps be more correct to say that it was generally acquiesced in, and the result demonstrated the practicability of preventing an annoyance which does more than anything else to deter a large class of the community frequenting the ordinary places of public entertainment in Hokitika. ${ }^{115}$

Attracting an audience which met particular social expectations of civility and decorum was vital for establishments hoping to reinforce their own propriety in public discourse. Bartlett largely succeeded in this regard and the reputation of the Prince of Wales was rarely called into question.

The extent to which smoking prohibitions moulded into classist critiques levied by theatregoers seeking to reinforce distinctions between respectable and disreputable patrons deserves some attention. In Auckland in September 1870, the press reported that individuals 'indulging in smoking within the theatre' threatened the comfort of the rest of the audience whilst simultaneously revealing their own inferior status:

At times last night the air was stifling in the dress circle with the fumes from below. Pride, if no higher motive, should prevent those who indulge in such practices from

\footnotetext{
${ }^{110}$ New Zealand Herald, 19 April 1864, p.4.

${ }^{111}$ DSC, 26 May 1869, p.3.

${ }^{112}$ Auckland Star, 30 March 1870, p.2.

113 ibid.

${ }^{114}$ May, p.40.

${ }^{115}$ WCT, 12 April 1866, p.3.
} 
showing that they smoke cheap and nasty cigars, or tobacco little better than that used for sheep-wash. ${ }^{116}$

Critics condemned the objectionable behaviour of the 'denizens of the pit' and in Christchurch in 1870, the Press correspondent was pleased to report that management at the Theatre Royal had taken 'stringent measures...to check the very annoying practice of smoking in the pit. ${ }^{117}$ Commentaries regularly highlighted the detrimental effect that smoking in the pit or stalls had on the inhabitants of the dress circle. Certainly, those seated higher in the theatre space were more at risk of being adversely affected, but it is notable that very few critics identified any objectionable behaviour of this nature among their contemporaries.

In Queenstown, criticism over smoking in Tom Fawcett's Theatre Royal highlighted both the practical and moral risks of allowing such behaviour to go unchecked. Speaking following 'several communications' which were 'not without good foundation', the editor of the Lake Wakatip Mail felt compelled to address complaints about those engaging in this 'ungentlemanly habit.' ${ }^{118}$ Not only was the practice detrimental to the moral health of the audience - there being ladies present in the auditorium - it had a profound effect on the performers themselves. Excepting the presence of women, the paper declared, smoking would be 'less reprehensible' if only indulged in during dramatic performances, 'when the inconvenience to the actors would not be of so much account. ${ }^{119}$ As it was, smokers in the stalls seriously impaired the ability of resident songstress Eliza Royal to reach her full potential. 'It is really a pity', the critic stated, 'to notice the evident exertion under which the singers practice their vocation, labouring under the effects of such an impenetrable fog in their faces. ${ }^{120}$ The critique likened the experience of performing in such an environment to singing 'with one's head up a chimney, under the stimulating effect of a fire of green wood' and noted that the 'glory' of the performers was thus 'proportionately reduced.' ${ }^{121}$ As the press noted:

Till the frequenters of this theatre can so far control their habits as to refrain from this practice they have only themselves to blame if, instead of the glowing and impassioned strains of our great operatic composers, they get but tame ballads, the simplicity of which enables the singer to acquit herself with tolerable ease. ${ }^{122}$

\section{Theatre Disorder}

Audience behaviour both buttressed and undermined the hard work of managers striving to promote an image of respectability. Alongside the provision of entertainment, theatres offered space for social

\footnotetext{
${ }^{116}$ DSC, 28 September 1870, p.2.

${ }^{117}$ DSC, 26 May 1869, p.3; Press (Christchurch), 21 April 1870, p.2.

${ }^{118}$ LWM, 14 October 1863, p.4.

119 ibid.

120 ibid.

121 ibid.

122 ibid.
} 
mixing where people of different classes came into close contact. The playhouse was a space of amusement and opportunity, but also of disorder, danger, and risk. Venues thus occupied a morally dubious position, and patrons knew that attendance entailed certain hazards. In the gold towns, where mineral wealth was both plentiful and ephemeral, this anxiety was heightened. Capitalising on audience demand for refreshments, many playhouses also sold alcohol. Drunkenness was, therefore, a regular headache for managers, and many theatres engaged the services of local police to manage any outbreaks of disorder. Analysis of cases brought to court during the 1860s provides some insight into patterns of disorder which threatened the propriety of local venues.

Condemnation of theatres as sites of moral degradation, civil disobedience, and general disorder was not mere fabrication. The public space of the theatre was used by different groups for various purposes, and the focus was not always on what was occurring on stage. Crowded auditoriums offered a host of possibilities for those engaging in less reputable activities. The liminal space of the vestibule, dividing the imagined world of the auditorium from the reality of the street, was also a risky space inhabited by light-fingered and intoxicated patrons and loiterers. For some, the theatre provided entertainment and escapism; for others, it offered anonymity and a chance to scope out prospective targets. In June 1866, for example, the West Coast Times reported that members of the infamous Burgess Gang had been seen 'oftener than once present in the dress circle of the Prince of Wales Opera House. ${ }^{123}$ While in this instance the nearby police camp emerged as the eventual target, unsuspecting theatregoers were not always so fortunate.

Dunedin's theatres had been open little more than a month when the first charge was brought before Resident Magistrate Alfred Chetham Strode, by Constable James Nimon, in April 1862. The case was, to all intents and purposes, a minor one as defendant, William Livingstone, was charged with having thrown two empty soda water bottles into the pit from his seat in the balcony. The constable's testimony stated that Livingstone was 'the worse for liquor at the time' and noted that some theatre patrons were 'in the habit of taking soda-water bottles, filled with liquor' into the auditorium and disposing of them, as Livingstone had done, when they were emptied. ${ }^{124}$ Livingstone's case was dismissed by the court on the condition that he did not repeat the offence.

Constable Nimon was to appear in several further court reports that year. The second incident occurred in May when he was assaulted by Thomas Wallace while attempting to enforce the Princess Theatre's ban on smoking. The prosecution argued that Wallace had 'conducted himself in a most disgraceful manner' throughout the performance and pushed Nimon to the ground when confronted. He was arrested outside the theatre as he departed and charged $£ 3$ for his troubles. Corroborating Nimon's testimony, further witnesses noted that the theatre was often used as a respite for disreputable sorts, it being 'the custom of many people to repair to the Theatre where they did just as they pleased, in

${ }^{123} O W, 2$ June 1866, p.11.
${ }^{124} O D T, 12$ April 1862 , p.4. 
consequence of only one constable being stationed there. ${ }^{125}$ Reports of disorder influenced police policy. By June, when Nicholas Newton and John Pelling were charged with drunkenness and disorderly conduct, there were three police witnesses in attendance. Nimon, being one, testified that Pelling's conduct had been 'excessively bad and disgraceful' and that the defendant had 'used abusive language towards Detective Hitchins. ${ }^{, 26}$ The pair, drunk at the time, were fined 20 s apiece.

Alongside drink-related incidents, petty theft was common. ${ }^{127}$ Throughout the 1860 s, Dunedin's theatregoers reported the disappearance of watches, pocketbooks, and opera glasses. ${ }^{128}$ Several potential perpetrators were identified, and some were charged. Other victims were less accusatory. Henry Diamond, for example, announced that he had misplaced his pocket-book, containing $£ 40$, after attending a performance at the Princess Theatre in November 1862, and John Watkins used the Police Gazette to notify the public of the loss of his raincoat, with $£ 3$ to $£ 4$ worth of gold in the pocket, in October $1864 .{ }^{129}$ However, thefts taking place within the theatre were not the only threats to theatregoers' belongings. Several cases heard by the Resident Magistrate highlight the use of the theatre as a site for prospective criminals scoping out promising targets.

Thieves frequented the vestibule of the theatres and often targeted those who were a little worse for wear from liquor or had collected change for refreshments purchased from the theatre bar. In April 1863, miner James Campbell was accosted by William Bloomfield and Alex McCutcheon in the street outside the Princess Theatre at the close of the performance. Detective Farrell, the officer on duty that evening, testified that he had observed the defendants 'paying particular attention to the prosecutor', who was under the influence of alcohol, before the audience had left the building. ${ }^{130}$ In July that same year, seaman James McKay held off two assailants who attempted to rob him in the sale yards of the Provincial Hotel after they had witnessed him collect his change for a drink purchased at the playhouse. $^{131}$

Despite efforts to promote respectability, theatres were still interpreted as public spaces where the usual checks and balances of appropriate social behaviour were less rigidly enforced. Cases of general disorder highlight the kernel of truth underpinning perceptions of playhouses as threats to social morality and civic order. In October 1863, James Gilchrist was charged with breaching the peace and fined 20s for striking a fellow member of the audience 'without any seeming provocation' while leaving the auditorium. ${ }^{132}$ Gilchrist also appeared in the Dunedin Police Court, receiving a second 20s fine, in

\footnotetext{
125 ODT, 3 May 1862, p.5.

${ }^{126}$ ODT, 2 June 1862, p.5.

127 'Schmidt vs Charles Wilkie - Stealing from the Person', Dunedin Trial Files, Ref: R25319275, Dunedin, ANZ.

${ }^{128}$ Otago Police Gazette, 24 November 1862, p.113; Otago Police Gazette, 1 October 1864, p.90; Otago Police Gazette, 14 March 1864, p.32.

${ }^{129}$ Otago Police Gazette, 24 November 1862, p.115; Otago Police Gazette, 1 October 1864, p.92.

${ }^{130}$ ODT, 13 April 1863, p.5.

${ }^{131}$ ODT, 10 July 1863, p.5.

${ }^{132}$ ODT, 31 October 1863, p.9 supp.
} 
July 1869 for throwing a package of sausages onto the stage during a performance. ${ }^{133}$ Earlier that year, Paul Frank had been fined $£ 5$ for throwing a live rat at actress Annie Towers during a performance at Auckland's Duke of Edinburgh Theatre. The incident, described by the Daily Southern Cross as 'a very serious one', resembled a previous incident when 'a certain person had...thrown a bunch of carrots upon the stage, leading to lawsuits and all sorts of things. ${ }^{134}$

Complaints about the use of obscene language also appeared with regularity and, despite their reputation for civility and propriety, several female patrons proved troublesome in this regard. Anne Nolan and Rebecca Gideon were both charged with such an offence in May 1864, but the case was dismissed. ${ }^{135}$ Later, in June, Sarah Kildey and Mary Brown were charged with disorderly conduct for fighting in the vestibule of the Princess Theatre and each fined 30s. ${ }^{136}$ Fights were common. Following the charge against Kildey and Brown at least eight others were convicted of a similar offence. ${ }^{137}$ While the connection between drink and disorder was not made explicit in these cases it was certainly a compounding factor elsewhere. Several theatregoers ended up before the courts on charges of drunkenness during the 1860 s. $^{138}$

With reasonable admission prices, often beginning at $1 \mathrm{~s}$ or $2 \mathrm{~s}$, and little to prevent others loitering in the vestibule, theatres offered an accessible public space for disreputable characters to congregate. The fact that the comparatively limited police presence was consciously utilised by people of questionable intent is significant. This use of theatres by those on the margins of society was also occasionally emphasised in court trials. John Brady, charged with vagrancy in 1869 , for example, was identified by Detective Farrell as having fallen into the habit 'of attending the vestibule of the Theatre, and picking up drunken men. ${ }^{139}$ During the trial of another vagrant, Allan McGuire, in January 1864 Dunedin police noted that the defendant was 'nightly in and about the Theatre, in bad company.' ${ }^{140}$ Theatres, as public spaces open late hours, were continuously forced to combat associations with more disreputable pastimes.

In London, strong social criticism was levied against theatres because of the intrinsic link which was perceived to exist between playhouses and prostitution, drunkenness and gambling. ${ }^{141}$ It is clear, from the evidence presented here, that such patterns of behaviour carried over into the settler colonial society of 1860s Dunedin. As well as being a form of commerce, prostitution was also 'a crime against

\footnotetext{
${ }^{133}$ GRA, 17 July 1869 , p.2.

${ }^{134}$ DSC, 12 March 1869, p.4.

${ }^{135}$ ODT, 27 May 1864, p.5.

${ }^{136}$ ODT, 9 June 1864, p.6.

${ }^{137}$ ODT, 25 February 1868, p.4; ODT, 18 May 1869, p.3; ODT, 23 June 1869, p.2; ODT, 16 November 1869, p.2.

${ }^{138}$ ODT, 2 June 1862, p.5; ODT, 22 April 1869, p.3; ODT, 20 July 1869, p.3; ODT, 18 September 1869, p.3.

${ }^{139}$ ODT, 15 June 1869, p.2.

140 ODT, 1 January 1864, p.5.

${ }^{141}$ Bratton, West End Stage, p.24; Davis and Emeljanow, p.98.
} 
middle class morality. ${ }^{142}$ In Britain, the respectability of various playhouses or music halls was regularly debated and torpedoed in the press and the plethora of entertainment venues ensured that the reputation of a given venue could shape patrons' decisions to attend. ${ }^{143}$ In colonial New Zealand, where access to theatrical entertainment was limited, there was less opportunity to be selective. Disorder and moral health were debated at a broad level, and certainly some facets of society steered clear of the playhouses when particular programmes were advertised, but, with theatres staging such diverse repertoires, there were few who took objection to individual establishments in a manner resembling the character assassination which pitted the British periodical press.

Supporters and critics of theatre each emphasised the need to provide and foster a taste for rational amusement. Being both popular and widely accessible, theatre was hotly debated because its various successes and failures stood as salient and influential markers of public intellect, taste, and refinement. Demonstrating the significance of theatre as a delineator of popular respectability, orators on both sides sought to highlight the moral threat posed by certain brands of amusement. Those opposed to theatre on principle used these genres to condemn the entire medium, but proponents worked tirelessly to emphasise the distinction between the civilizing influence of respectable theatre and the threat to social mores posed by more raucous and vulgar forms. Playhouses, their patrons, managers, and performers, were topics of debate, and targets of regulation, in part because the public amusements on offer reflected and debated the general character, intelligence, and values of colonial society. The substantial efforts undertaken by managers and government officials to regulate audience behaviour and repertoire, coupled with the extent to which discussion of the virtues and vices of theatre and drama permeated public discourse, highlight theatre's place as a consequential component of colonial culture and marker of civic progress.

\footnotetext{
${ }^{142}$ Heather Lucas, 'Square Girls: Prostitutes and Prostitution in Dunedin in the 1880s', BA(Hons) research essay, University of Otago, 1985, p.1.

${ }^{143}$ Phillips, pp.195-213.
} 


\section{Conclusion}

Theatres established throughout New Zealand during the mid-nineteenth century offered colonial audiences, even those in smaller settlements, access to a vast array of live performance and popular dramatic amusements. Playhouses were prominent features of colonial towns which physically enlivened the architectural streetscape and brought patrons and performers together in the dim-lit space of the auditorium. Staging both contemporary repertoire and more traditional fare which attracted colonists seeking to promote their social sophistication, theatres entertained audiences from across the social spectrum. Distinct from the outside world, the imaginative space of the auditorium offered amusement and relaxation which gave theatregoers a temporary escape from the monotony and often harsh realities of colonial life. In addition, however, theatres were also sites of business, social mixing, heightened emotion, drunkenness, and disorder.

Military dramatics and goldrush wealth profoundly affected the character, and accelerated the growth, of theatre in New Zealand between 1850 and 1870. While evidence of the activity and reception of military amateurs is relatively sparse, concerted analysis of the existing record has demonstrated the scale and significance of theatrics staged in New Zealand's garrison camps during the mid-nineteenth century. The boundary between garrison and wider settler society in New Zealand was porous. With time and resources to devote to producing theatre, examination of military amateur dramatics provides a crucial insight into the activity of the garrison during the comparatively quiet 1850s. Garrison theatres provided theatrical amusement in settlements generally considered too small to sustain resident professional companies. In doing so, they laid crucial foundations for the development of professional theatre by cultivating a taste for drama and proving that, even in New Zealand's smaller towns, there were receptive audiences large enough to sustain regular entertainments. Professional performers were quick to recognise these developments. In Auckland, for example, Foley's Theatre Royal and several other establishments developed quickly during the later 1850s to capitalise on the demand for amusement proffered by frequent patrons of the garrison playhouse.

Goldrush migration during the 1860s cemented New Zealand's place within a broader Anglo theatre network, expanding access to theatre in New Zealand by increasing the quality and number of venues as well as performers. Opportunities to perform for fresh audiences eager to spend their newfound wealth attracted performers from throughout Australasia and further afield. Beginning in 1862, the allure of gold catapulted Otago and the West Coast to the forefront of New Zealand's theatre scene for the remainder of the decade. Performers and managers such as Joey Gougenheim and James Bartlett, drawn by gold town demands for amusement, enriched the theatre scene throughout the colony by expanding access to professional entertainment as they travelled. Introducing current theatre repertoire reflecting trends in metropolitan Britain, Australia, and the United States, both soldiers and 
gold town performers played a crucial role in bringing New Zealand audiences within broader networks of cultural and material exchange which shaped empire and the wider Anglo-world.

The performers and managers who inhabited New Zealand's colonial playhouses brought with them existing reputations cultivated on touring circuits throughout New South Wales, Victoria, the United States, and Britain. Contrary to some contemporary criticism, actors treading the boards in Otago and elsewhere were not of an inferior quality to their metropolitan counterparts. In fact, with gold and enthusiastic audiences facilitating New Zealand's inclusion within broader touring circuits, network and spatial analyses demonstrate that many entertainers gracing the colonial stage were contemporary stars who had delighted patrons in San Francisco, New York, and on London's West End. Most arrived from Australia and, throughout the 1860s, Dunedin served as a regular point of entry to the colony as a whole. Joey Gougenheim, Mr and Mrs Charles Dillon, and Charles and Amelia Poole were among those who arrived in Dunedin with reputations cultivated in Britain and the United States. Ships arriving from Melbourne and Sydney which carried goods and livestock to sustain the physical development of the colony also conveyed dramatic literature, performers, and props which cultivated cultural life and fostered the development of professional theatre in New Zealand.

Empire was made through networks. ${ }^{1}$ Theatre networks, driven by novelty, commerce, and opportunity, extended access to shared forms of popular culture which shaped the perception of imperial space. The movement of theatre people and repertoire illustrated by the spatial analyses in this study, map the scale and shape of these links which encompassed Britain, Ireland, and North America as well as Britain's settler and crown colonies. The network of performance which brought Haymarket comediettas, London favourites, and startling stage effects to audiences in New Zealand was multidirectional. As performers from the West End and provincial English theatres trod the Otago boards in 1863, for example, Queen Victoria was welcoming William Jenkins and his Māori touring group to Osborne House on the Isle of Wight. ${ }^{2}$

Theatre networks flowed and foundered as the fortunes of performers and venues waxed and waned according to the support, or lack thereof, from patrons demanding novel entertainments. These networks were exceedingly active and highly mobile, bustling with activity as players and managers travelled, sometimes daily, from place to place. The movement of performers was driven by access to audiences. Factors which drove the development of suitable audience pools, however, varied significantly. Theatre networks did not have singular drivers, but all followed broader patterns of movement propelled by various factors, such as gold and pastoral wealth, which created sizeable and enthusiastic constituencies of theatregoers. The networks illustrated in this thesis present a microcosm, in both time and location, of a much broader pattern of activity.

\footnotetext{
${ }^{1}$ Laidlaw.

${ }^{2}$ Chanel Clarke, 'Dressing for the Camera: Queen Victoria's Māori Subjects and the Māori Party Tour of England, 1863', NZJH, vol.52, no.1, 2018, pp.90-113.
} 
Theatregoing served dual purposes - constructing an imagined sense of place within the wider Anglo-world for theatregoers in New Zealand and aiding in the development of a more immediate sense of community in new and transient colonial settlements through the emotive experience of the auditorium. Situating audiences within a vast constituency of Anglo theatregoers, playhouses offered patrons access to a common Anglo theatre repertoire. Produced by itinerant theatre people tracking paths of cultural and material exchange, the theatrical fare on offer was diverse but largely comprised contemporary productions which were performed in venues throughout the empire and wider Angloworld. Popular melodramas, such as The Colleen Bawn and The Corsican Brothers, reached New Zealand with remarkable speed and were rendered with all the original effects, occasionally by some of the original performers. Networks of cultural and material exchange thus shaped the theatregoing experience in colonial New Zealand by providing audiences access to both talented entertainers with established professional reputations and contemporary popular repertoire.

Collapsing distance between dispersed audiences, theatre also shaped interpretations of imperial space and brought patrons into contact with the empire at large. The movement of repertoire played a significant part in this process, enabling colonial audiences to participate in the cultural trends of the British metropole and effectively condensing the imagined space between colonial playhouses and the West End. Very few productions featuring New Zealand characters, depicting local events, or written by local playwrights were produced during the focus period, most were British or American in origin. Marty Gould argues that theatre was useful in conveying imperialist discourse to metropolitan Britons. ${ }^{3}$ Assessing a colonial context, this study has demonstrated that the stage also brought New Zealand audiences into close proximity with events of empire, enlivened with all the colour, sound, and visual effects that the mechanics allowed. Dion Boucicault's depiction of the 1857 Indian Rebellion in sensation drama Jessie Brown is one example of how playhouses contributed to a body of popular culture which made empire, in all its crises and sensations, in the colonial imagination as well as in Victorian Britain. ${ }^{4}$

Arguments that colonial society was made not just materially but in the contemporary mind, through words and reinvention, benefit from concerted analysis of theatre in this context. Peter Gibbons has noted the degree to which the consumption and production of literature and print informed processes of colonisation. ${ }^{5}$ Theatre, likewise, enabled the ongoing introduction of Anglo repertoire, often following success in London, and thereby reinforced imagined connection with the British metropole. Some performances also depicted and sought to naturalise hierarchical representations of colonial power and violence. The breadth of engagement demonstrates that theatre was a prominent, accessible, and popular form of Anglo culture in colonial societies. Some evidence suggests that Māori also participated as theatregoers in these venues if not producers. Considering Becker's argument that the

\footnotetext{
${ }^{3}$ Gould, p.2.

${ }^{4}$ Bender; Wagner.

${ }^{5}$ Gibbons, p.9.
} 
reclamation of theatre space was used as a means of challenging colonial agendas in India, futher analysis of New Zealand would do well to more critically assess how Māori and Pākehā responded to theatres as spaces of public performance and promoters of Anglo culture. ${ }^{6}$

As places of business, theatres challenged conventional expectations of gendered work by offering women financial independence and opportunities for advancement. Theatrical conventions often challenged orthodox gender norms. However, despite risking condemnation and the possibility of being equivocated with prostitutes, women found viable employment in New Zealand's colonial playhouses and several rose to prominent positions within the theatre structure. Theatre, like other colonial amusements, was a risky venture and relied on consistent support from a limited pool of patrons. Insolvency petitions filed by several theatre managers demonstrate that theatre work was financially hazardous. Nonetheless, the likes of Lady Don and Joey Gougenheim achieved some success in theatre management, and, in New Zealand, theatre women were broadly accepted and seldom had their personal reputations called into question or their performances critiqued solely on the basis of gender.

Open late hours and offering space to congregate, playhouses brought disparate groups of people, with various intentions, together in a manner which often unsettled broader colonial agendas geared toward promoting social respectability. Contrasting interpretations of theatre as variously civilizing and corrupting shaped public interaction with the stage. To a significant degree, the discourse of respectability used to critique theatre and theatregoing reflected broader anxieties about the reputation of colonial settlements. Staging 'rational' entertainment enabled theatres to serve as prominent markers of civic progress and social sophistication but the line they walked was thin. Performances which threatened to corrupt or defy social sensibilities and existing codes of conduct, coupled with the extent to which the stage was interpreted as a barometer of social civility, saw playhouses treated with suspicion. Vocal critics, like Dunedin's “Enquiry” and Reverend Robert Ward, viewed theatre and its widespread popularity as a threat to productivity and social order, giving patrons and performers alike license to waste otherwise productive time with needless frivolity and affronting the colonial ethos of work and improvement. The heightened emotion of the stage, coupled with the consumption of alcohol, also corroded broader social discipline and restraint. Charges of drunkenness, theft, and disorderly conduct brought against patrons demonstrate the various ways playhouses were used and the degree to which theatregoing carried various moral and physical risks.

Victorian discourses of respectability had a profound effect on the operation and regulation of theatres. Playhouses and their workforce were subject to both legal and social regulation which sought to counter the perceived threat theatres posed to manners, decorum, and public peace. Targeting both patrons and repertoire, Otago's introduction of the Licensed Theatres' Ordinance in 1862 highlighted the degree to which theatres concerned authorities struggling to cope with the social impacts of large

\footnotetext{
${ }^{6}$ Becker, pp.699-725.
} 
scale goldrush migration. Debates over productive leisure enhanced promotion of legitimate dramas and other 'rational' amusements, and managers went to some effort to preserve the decorum of their venues. Bans on smoking proliferated as proprietors sought to ensure audience comfort and cultivate a respectable class of playgoer. Despite its widespread popularity, ongoing legal and social regulation demonstrate that theatre continued to occupy an uneasy position within colonial society, especially in Otago where proprietors of professional venues remained under the watchful eye of the Provincial Council.

Throughout, this thesis has experimented with spatial analysis and quantitative methods to address core questions, and extend archival material significantly limited by theatre's ephemeral nature. Analyses charting the movement of theatre people and repertoire, and subsequent links between New Zealand playhouses and established centres of culture elsewhere have vividly demonstrated the extent to which entertainment in colonial New Zealand operated within a broader network of cultural exchange. Examination of house size has highlighted the precarity of theatrical employment, and the limited extent to which the success or failure of theatre managers was impacted by gender. Finally, close examination of genre across the settlements at the centre of this study highlights the diversity and commonality of repertoire performed in colonial New Zealand and the degree to which managers used entertainment to buttress broader attempts to reinforce colonial respectability. In addition to offering some answers to the key research questions, these methods provide an insight into the utility of applying more quantitative tools to analyse fundamentally qualitative material and gain access to elements which often elude historical analysis.

On 28 October 1867, a large audience assembled at Hokitika's Prince of Wales Opera House - despite the strong gale outside - for Rosa Cooper's farewell performance. ${ }^{7}$ Arriving in Dunedin amidst the bustle of goldrush activity in 1864, Cooper had spent more than eighteen months performing for audiences in Greymouth and Hokitika. Now, the frenetic energy of the rush which had drawn thousands to the banks of the Hokitika River had begun to dissipate as the alluvial riches of the creek beds ran dry and reports of a payable field at Thames accelerated departures. By November, for the first time since the beginning of the rush, those leaving the West Coast exceeded arrivals. ${ }^{8}$

Stepping forward into the footlights as the curtain fell, Cooper delivered a short address acknowledging her time in Hokitika. 'The first dramatic lines of dialogue delivered on this stage', she noted, reflecting on the opening of Bartlett's costly establishment in March 1866, 'were spoken by myself, and since that time, with but a few weeks intermission, I have nightly had the honour of appearing before you. ${ }^{9}$ Bound for Sydney, Cooper expressed 'a deep and sincere regret in parting from very many dear and valued friends.' 'And now ladies and gentlemen', she concluded, 'let me say

\footnotetext{
${ }^{7}$ WCT, 1 November 1867, p.2.

${ }^{8}$ Philip Ross May, The West Coast Gold Rushes, (Christchurch: Pegasus Press, 1962), pp.232-233.

${ }^{9}$ WCT, 1 November 1867, p.2.
} 
farewell. It is a disagreeable word at any time to speak, but doubly so when spoken for the last time; and if I linger on the word it is because I would say much more "but fear to say it". To you, then, and all kind friends in Hokitika I bid farewell. ${ }^{10}$

Cooper's departure signalled the beginning of the end of an era of prosperity for professional theatre on the West Coast. While Bartlett and various colleagues battled on for more than a year, the golden period of energy and wealth which had so transformed the previously quiet coastline was drawing to a close. By 1869, Bartlett's establishment had closed its doors and the majority of the performers and craftsmen who had brought the works of Shakespeare, Sheridan, and countless others to life for gold-seekers in search of amusement had packed their bags and moved to search for work in the colony's growing urban centres or left New Zealand entirely.

Elsewhere, professional and amateur theatre continued to grow as the consolidation of steamship routes and Julius Vogel's immigration policies expanded the theatre population and prospective audiences. ${ }^{11}$ Building upon foundations laid by amateurs and early professionals, the practice of theatregoing now formed a regular part of social life. Even with the introduction of motion pictures later in 1896 and the development of purpose-built cinemas throughout the early twentieth century, theatre remained a prominent part of cultural life in New Zealand. The enterprise of military amateurs and goldrush entertainers during the 1850s and 1860s had succeeded in laying the foundations of an energetic entertainment industry.

\footnotetext{
10 ibid.

${ }^{11}$ Chris Brickell, 'Men Alone, Men Entwined: Reconsidering Colonial Masculinity', Journal of New Zealand Studies, no.13, 2012, pp.11-33. Brickell's study of amateur theatre in Masterton incorporates network analyses to demonstrate the significance of theatre as a driver of sociability and connection.
} 


\section{Appendix I: Performance Database}

The Performance Database, with data is drawn from reports, notices, advertisements, and reviews which appeared in contemporary newspapers, underpins much of the quantitative and spatial work presented in this thesis. The newspapers, available digitally through Papers Past, were systematically analysed using keyword searches followed by a manual eyesight scan. The core publications used were the Daily Southern Cross (Auckland), Otago Daily Times (Dunedin), Grey River Argus (Greymouth), West Coast Times (Hokitika), Taranaki Herald (New Plymouth), and Lake Wakatip Mail (Queenstown).

Publications were initially searched by keyword (i.e. 'theatre', 'Prince of Wales Opera House', 'Burlesque', 'Colleen Bawn' 'Boucicault') and data for performances between 1850 and 1870 was transcribed. Next, a systematic search of papers was conducted, examining each issue of newspapers from all focus locations excluding Dunedin for which the database already contained a significant sample. Close examination of this nature enabled gaps in the dataset to be filled. While some newspaper issues were missing from the Papers Past collection, the database provides a near complete record of theatrical performances staged in the smaller focus settlements.

The information collated by the database extends examination beyond the particulars of the play to include ticket prices, notes on audience reception, details of debut performances, and a record of whether the performance was staged for a charitable purpose. As such, the database opens several avenues for further analysis. Geographic data for each performance allows for spatial examination of the prevalence and diversity of theatrical entertainment within New Zealand. Price data allows for examination of the accessibility of theatre as a form of public amusement. Debut performance data also provides an insight into the contemporary popularity of the repertoire on offer in New Zealand's colonial playhouses, allowing for close examination of the movement of plays through the Anglotheatre network discussed in chapter one.

The analyses conducted using this data collated from dispersed and often ephemeral sources, highlight the utility of applying more systematic analysis to fundamentally qualitative material. The database has enabled examination of the geographic spread of theatre and the contemporary popularity of repertoire staged in New Zealand's playhouses, thereby enriching understanding of theatre as an accessible form of popular culture during the mid-nineteenth century and the significance of various networks of culture and commerce which brought New Zealand within the broader cultural space of the empire and wider Anglo-world. 
The final Database contains a full record of newspaper-advertised performances for Hokitika (1866 1869), Greymouth (1866 - 1868), Queenstown (1863 - 1864), and military performances in Auckland (1851 - 1858) and New Plymouth (1857 - 1861). Data for Dunedin is incomplete but provides a useful sample of performances staged between 1861 and 1869. There are 1622 total records structured as follows:

\begin{tabular}{|l|l|l|}
\hline Column & Details & Example Entry \\
\hline Column A: Play & Title of production & A Blighted Being \\
\hline Column B: Theatre & Theatre where production was performed & $\begin{array}{l}\text { Prince of Wales } \\
\text { Opera House }\end{array}$ \\
\hline Column C: Town/City & $\begin{array}{l}\text { Settlement where production was } \\
\text { performed }\end{array}$ & Hokitika \\
\hline Columns D - F: Date & Date of performance & 11 Apr 1866 \\
\hline Column G: Genre & Genre of performance & Farce \\
\hline Columns H - O: Price & Ticket prices for different seats & $\begin{array}{l}\text { £3/3s boxes, 5s } \\
\text { dress circle, } 4 s \\
\text { stalls, 2s pit }\end{array}$ \\
\hline Column P: Notes Prices & Any special prices i.e. $1 / 2$ for children & \\
\hline Column Q: Ticket Notes & Where tickets could be purchased & \\
\hline Column R: Reception & Critical/Audience response & \\
\hline Column S: Audience Notes & Size of house & \\
\hline Column T: Garrison/Gold Town & Whether location is garrison or gold town & Gold town \\
\hline Column U: Debut year & Year of debut performance or publication & 1854 \\
\hline Column V: Where Performed & Location of debut performance & London \\
\hline Column W: Playwright & Name of playwright & Tom Taylor \\
\hline Column X: Nationality & Nationality of playwright & English \\
\hline Column Y: Source & Newspaper information obtained from & WCT \\
\hline Column Z: Company & Performers, if specific group mentioned & \\
\hline Column AA: Benefit & $\begin{array}{l}\text { If performance is a benefit and if so, for } \\
\text { who }\end{array}$ & Mr Greenfield \\
\hline
\end{tabular}




\section{Appendix II: Spatial Maps}

The spatial maps presented throughout this thesis were constructed in R (see code below) and R Shiny. $\mathrm{R}$ is an open source programming language used for statistical computing and data visualisation. The $\mathrm{R}$ Shiny package extends R's web interactivity framework to produce web applications with various interactive features. Data for the visualisations was drawn from the Performance Database. Coordinates were added to relevant data series from the original dataset to construct the worksheet underpinning each map. Popups were included in most maps to provide more detail for each node. The Genre Analysis map was produced using R Shiny which enabled an interactive time slider input to be added. All other maps were produced using the leaflet package in R. The dataset for each map followed a similar structure. Data for the legitimate drama map, for example, was structured as follows:

\begin{tabular}{|l|l|l|}
\hline Column & Details & Example Entry \\
\hline Column A: play & Name of play & A Blighted Being \\
\hline Column B: location & Where play was performed & Hokitika \\
\hline Column C: lat & Latitude coordinates & -42.71666 \\
\hline Column D: lon & Longitude coordinates & 170.96666 \\
\hline Column E: genre & Genre of performance & Farce \\
\hline Column F: legitimate & If play was "legitimate" drama & No \\
\hline Column G: playwright & Playwright name & Tom Taylor \\
\hline Column H: colour & Node colour & skyblue \\
\hline Column I: written & Year play was written & 1854 \\
\hline
\end{tabular}

\section{Sample Code:}

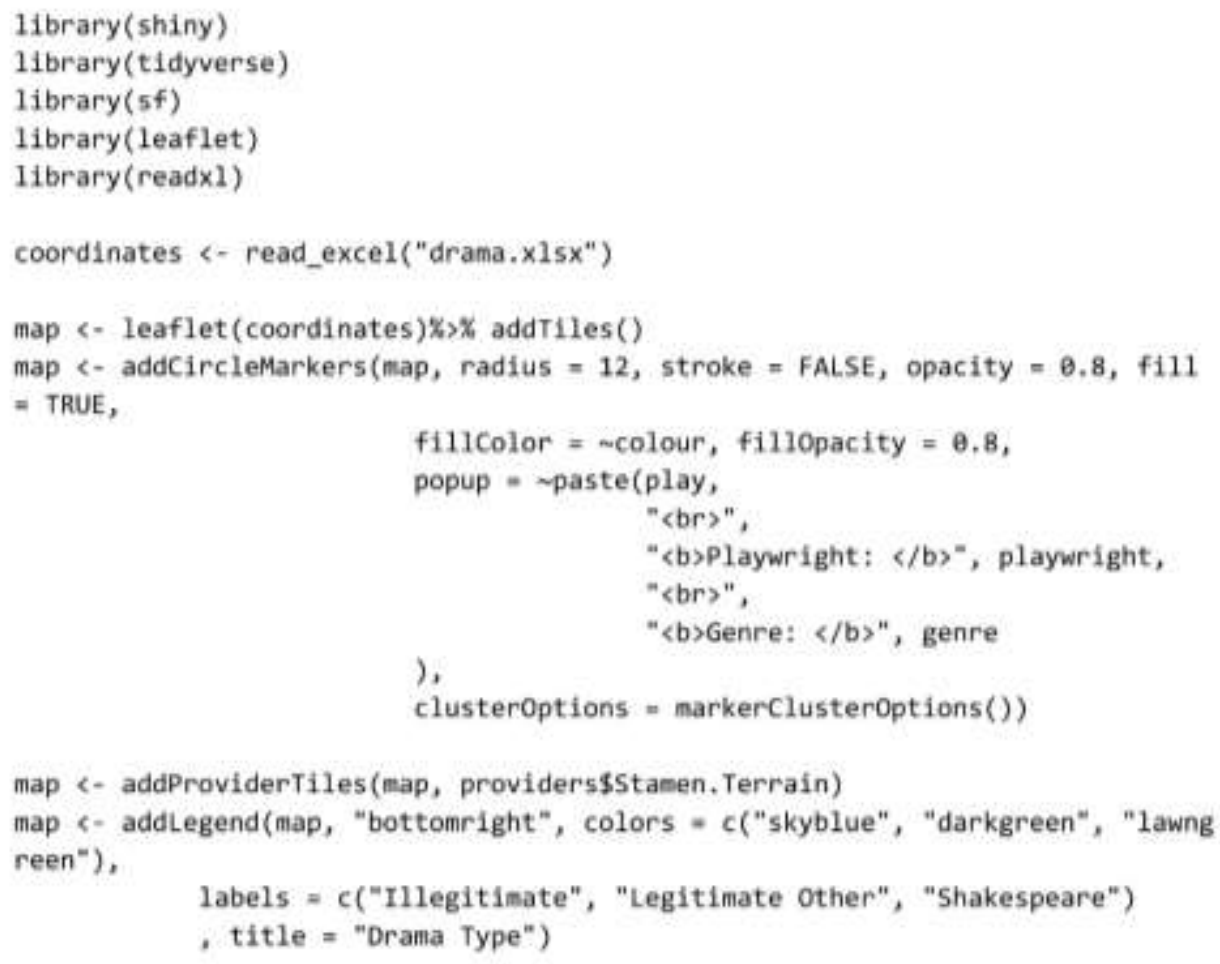




\section{Bibliography}

Digital maps and networks: www.entertainingprospects.weebly.com

\section{Primary Sources}

\section{a) Newspapers and Periodicals}

Papers Past (New Zealand): https://paperspast.natlib.govt.nz

Auckland Chronicle and New Zealand Colonist, 1844

Auckland Star, 1870

Cromwell Argus, 1870 - 1876

Daily Southern Cross (Auckland), 1850 - 1869

Dunstan Times, 1870 - 1876

Evening Post (Wellington), 1866

Evening Star (Dunedin), 1870 - 1876

Grey River Argus (Greymouth), 1866 - 1876

Lake Wakatip Mail (Queenstown), 1863 - 1864

Lake County Press, 1876

Lyttelton Times, 1866

Mount Ida Chronicle, 1870

Nelson Examiner and New Zealand Chronicle, 1864 - 1866

New Zealand Herald (Auckland), 1864

New Zealand Spectator and Cook's Strait Guardian (Wellington), 1850

North Otago Times, 1864

Otago Daily Times $1862-1875$

Otago Police Gazette, 1862 - 1864

Otago Provincial Government Gazette, 1862 - 1870

Otago Witness, 1864 - 1908

Press (Christchurch), $1865-1870$

Southland Times (Invercargill), 1863

Taranaki Herald, 1857 - 1861

Timaru Herald, 1866 - 1876

Tuapeka Times, 1870 - 1876

Wellington Independent, 1860 - 1866

West Coast Times (Hokitika), 1866 - 1876

Westport Times, 1876

Trove (Australia) - https://trove.nla.gov.au

Adelaide Express, 1864

Age (Melbourne), 1857

Argus (Melbourne), 1862 - 1872

Australasian (Melbourne), 1870

Bell's Life in Sydney and Sporting Chronicle, 1870

Bendigo Advertiser, 1857 - 1867

Empire (Sydney), 1854 - 1864

Evening News (Sydney), 1875

Geelong Advertiser, 1864

Herald (Melbourne), 1862 - 1875

Kyneton Guardian, 1870 
Launceston Examiner, 1864

Mackay Mercury and South Kennedy Advertiser, 1870

Maryborough and Dunolly Advertiser, 1857

Mercury (Hobart), 1862 - 1865

Portland Guardian (Dunolly), 1858

Star (Ballarat), 1857 - 1874

Sydney Mail and New South Wales Advertiser, 1871

Sydney Morning Herald, 1856 - 1871

Sydney Punch, 1865

British Newspaper Archive - https://www.britishnewspaperarchive.co.uk/

Bombay Gazette, 1858

Era, $1853-1874$

Illustrated London News, 1855

Kenitsh Chronicle, 1861

Liverpool Mercury, 1868

Newcastle Courant, 1877

Newcastle Journal, 1868

Chronicling America - https://chroniclingamerica.loc.gov/

Chicago Tribune, 1868

Daily Dispatch (Richmond, VA), 1860

Evening Star (Washington D.C.), 1861

Evening Telegraph (Philadelphia), 1866

Gold Hill Daily News, 1868

Nashville Patriot, 1860

New Orleans Daily Crescent, 1859

New York Tribune, 1859 - 1889

New York Herald, 1875

California Digital Newspaper Collection - https://cdnc.ucr.edu/

Daily Alta (San Francisco), 1855 - 1861

Marysville Daily Herald, 1855

Nevada Democrat (Nevada City, CA), 1861

Placer Herald (Auburn, CA), 1858

Sacramento Daily Union, 1855 - 1861

San Jose Mercury, 1861

\section{b) Unpublished}

\section{Archives New Zealand (ANZ), Dunedin Regional Office}

'DALE, Robert Baldwin - Dunedin - Comedian', 1864, Dunedin Debtors Petition Files, Ref: R19952689, Dunedin, ANZ.

'MUNFORD, William Henry - Dunedin - Theatrical Manager', 1866, Dunedin Debtors Petition Files, Ref: R19952920, Dunedin, ANZ. 
'O'BRIEN, Francis Stuart - Dunedin - Comedian', 1866, Dunedin Debtors Petition Files, Ref: R19952974, Dunedin, ANZ.

'Petition - John Sibbald (1): That the Princess Theatre may be exempted from Licensed Theatres Ordinance 1862 - 13 May 1870’, 1870, Otago Provincial Council Papers, Ref: R19002729, Dunedin, ANZ.

'Petition - Louis Court (1): For redress over partial operation of Licensed Theatres Ordinance - 13 May 1869', 1869, Otago Provincial Council Papers, Ref: R19002521, Dunedin, ANZ.

'ROWE, Thomas Wright - Dunedin - Comedian', 1864, Dunedin Debtors Petition Files, Ref: R19952576, Dunedin, ANZ.

'RYAN, William - Dunedin - Comedian', 1866, Dunedin Debtors Petition Files, Ref: R19952985, Dunedin, ANZ.

'Schmidt vs Charles Wilkie - Stealing from the Person', Dunedin Trial Files, Ref: R25319275, Dunedin, ANZ.

'Select Committee - Private Petitions: Interim Report No 4 on Petition of Louis Court - 18 May 1869’, 1869, Otago Provincial Council Papers, Ref: R19002484, Dunedin, ANZ.

'WILLIS, John Stanley - Dunedin - Scenic Artist', 1866, Dunedin Debtors Petition Files, Ref: R19952978, Dunedin, ANZ.

\section{Ephemera}

'Collection of theatre broadsides relating to Lady Don and her tours of Tasmania, Victoria, New South Wales, New Zealand and the United States of America', 1864-1866, Ref: PA Broadside 53/1-45, National Library of Australia (NLA).

'Handbill for Military Theatre, Albert Barracks', 58 ${ }^{\text {th }}$ (Rutlandshire) Regiment of Foot - Papers, 19

December 1855, Ref: MS-102-OS-2, Auckland War Memorial Museum (AWMM).

'Military Theatre', 27 August 1855, Ephemera, Ref: EPH-W3-16, AWMM.

'Military Theatre, Marsland Hill', 1857, Archives, Ref: ARC2004-203, Puke Ariki.

'Second and Third Pages of Military Theatre Programme', 1857, Ref: MS-Papers-2808-02, ATL.

W. Collins - Taranaki News Office, 'Military Theatre, Marsland Hill [Playbill]', 3 July 1857, Archives, Ref: A59.664, Puke Ariki.

W. Collins - Taranaki News Office, 'Military Theatre', 19 June 1857, Ephemera, EPH-W3-14, AWMM.

\section{Personal Papers}

An Old Hand, 'Memories of the Past, Auckland from 1847', in New Zealand Pamphlets Vol.21, Ref: AC911, AWMM.

Burn, David, 'David Burn Diary, 10 October 1855 - 15 September 1858', Microfilm: CY 1094, Ref: 844931, Mitchell Library, Sydney. 
Chevalier, Caroline, 'Chevalier, Caroline: A short description of a journey across the South Island of New Zealand from East Coast to West Coast and back from West to East Coast', Ref: MS0143, Hocken Library, Dunedin.

Dr Peter Wilson to Donald McLean, 1 May 1854, New Plymouth, Ref: MS-Papers-0032-0649, ATL. Finnane, Mark (ed.), The Difficulties of My Position: The Diaries of Prison Governor John Buckley

Castieau, (Canberra: National Library of Australia, 2004).

Hay, William and Mary, 'Letters from William and Mary Hay, Hokitika', Ref: MS-Papers779, ATL.

Holt, Clarance, 'Twice Around the World or Recollections of an Old Actor', Ref: MS0224/2/1, NLA. J.L. Campbell to Dr J. Campbell, 30 May 1851, in R.C.J. Stone, Young Logan Campbell, (Auckland: Auckland University Press, 1982).

Pickard, Arthur Frederick, 'Diary, Private A F Pickard', 1860-1863, Ref: 76173, MTG Hawke's Bay. Rogan, John to Donald McLean, 16 February 1858, Donald McLean Papers, Ref: MS-Papers-00320540, ATL, https://paperspast.natlib.govt.nz/manuscripts/MCLEAN-1009392.2.1.

Story, Edith Mary, 'Stories of the Gold Diggings', Ref: fMS-Papers-7868, ATL.

Watmuff, John Henry, 'The journals of John Henry Watmuff - New Zealand extracts, 18611864/transcribed by Stephen Arnold (1861-1864(2006))', Ref: Misc-MS-2000, Hocken Library, Dunedin.

William Halse to Donald McLean, 2 May 1854, New Plymouth, Ref: MS-Papers-0032-0318, ATL

\section{Photographs}

'Portrait of actress, Julia Mathews', 1863, Ref: PIC/15840, NLA.

'Queenstown', ca 1860s, Ref: 1/2-049217-F, ATL.

\section{c) Published}

Bathgate, Alexander, Colonial Experiences or Sketches of People and Places in the Province of Otago, New Zealand, (Glasgow: Maclehose and MacDougall, Glasgow University Press, 1874).

Ballantine, James, The Life of David Roberts, R.A.: Compiled from His Journals and Other Sources, (Edinburgh: Adam and Charles Black, 1866).

Boucicault, Dion, Jessie Brown or The Relief of Lucknow, (New York: Samuel French, 1858).

Boucicault, Dion, The Colleen Bawn or The Brides of Garryowen, (New York: Samuel French, 1869). Jerrold, Douglas William, Black-eyed Susan, or, “All in the downs, ” (New York: Clinton T. De Witt, 1854).

Taylor, Tom, Our American Cousin, (1869).

Ward, Rev. Robert, Life Among the Maories of New Zealand: Being a Description of Missionary, Colonial and Military Achievements, (London: G. Lamb, 1872). 


\section{Appendices to the Journal of the House of Representatives (AJHR)}

John Bathgate to the Honourable Minister of Justice, 5 June 1874, 'Licensing Act of 1873

(Instructions and Correspondence Relating to)', AJHR, Session I, H-21, pp.3-4.

'Report on the Otago Gold Fields', AJHR, 1863, Session I, D-06.

\section{Otago Provincial Council}

'Votes and Proceedings of the Provincial Council of Otago', Otago Provincial Government Gazette, Session XVI, 1862, (Dunedin: Printed by Authority, Daniel Campbell, 1863).

\section{d) Legislation}

Debtors and Creditors Act, 1862.

Licensed Theatres' Ordinance, 1862, Otago Provincial Government.

Licensed Theatres' Ordinance, 1870, Otago Provincial Government.

\section{Secondary Sources}

\section{a) Articles}

Ballantyne, Tony, 'Mobility, Empire, Colonisation', History Australia, Vol.11, no.2, January 2014, pp.7-37.

—_ 'On Place, Space and Mobility in Nineteenth-Century New Zealand', New Zealand Journal of History (NZJH), Vol.45, no.1, 2011, pp.50-70.

Barker, Kathleen, 'A Provincial Tragedian Abroad', Theatre Research International, Vol.11, no.1, 1986, pp.31-48.

Becker, Tobias, 'Entertaining the Empire: Theatrical Touring Companies and Amateur Dramatics in Colonial India', The Historical Journal, Vol.57, no.3, 2014, pp.699-725.

Bhattacharya, Rimli, 'Promiscuous Spaces and Economies of Entertainment: Soldiers, Actresses and Hybrid Genres in Colonial India', Nineteenth Century Theatre and Film, Vol.41, no.2, November 2014, pp.50-74.

Booth, Michael R., 'Gold Rush Theater: The Theatre Royal, Barkerville, British Columbia', The Pacific Northwest Quarterly, Vol.51, no.3, 1960, pp.97-102. 
Brickell, Chris, 'Men Alone, Men Entwined: Reconsidering Colonial Masculinity', Journal of New Zealand Studies, no.13, 2012, pp.11-33.

Brown, Jared A., 'A Note on British Military Theatre in New York at the End of the American Revolution', New York History, Vol.62, no.2, 1981, pp.177-187.

Clarke, Chanel, 'Dressing for the Camera: Queen Victoria's Māori Subjects and the Māori Party Tour of England, 1863', NZJH, vol.52, no.1, 2018, pp.90-113.

Corsun, Elizabeth, 'Boxed-In: Women and Mid-Nineteenth Century Farce', Nineteenth Century Theatre and Film, Vol.41, no.1, May 2014, pp.21-37.

Davis, Tracy C., 'Female Managers, Lessees and Proprietors of the British Stage (to 1914)', Nineteenth Century Theatre and Film, Vol.28, no.2, December 2000, pp.115-144.

Dunstone, Bill and Helena Grehan, 'Making Maps "Speak": E-Mapping Performance on Western Australia's Coolgardie Goldfield, 1894-98', Australasian Drama Studies (ADS), no.62, April 2013, pp.89-99.

Dunstone, William and Helena Grehan, '“Chaos" and "Convergence" on the Western Australian Goldfields: The Politics of Performance in the 1890s', ADS, no.70, April 2017, pp.35-56.

Gibbons, Peter, 'Cultural Colonization and National Identity', NZJH, Vol.36, no.1, 2002, pp.5-17.

Herbert, Christopher, 'Life's Prizes are by Labor Got: Risk, Reward, and White Manliness in the California Gold Rush', Pacific Historical Review, Vol.80, no.3, 2011, pp.339-368.

Ince, Bernard, 'Spectres of Debt in the Victorian Theatre: A Case Study of Management Failure', Nineteenth Century Theatre and Film, Vol.41, no.1, Summer 2014, pp.68-84.

Kuch, Peter, 'Irish Playwrights and the Dunedin Stage in 1862: Theatre Patrons Performing Civility', Journal of New Zealand Studies, no.15, 2013, pp.90-100.

Macdonald, Charlotte, 'Woolwich to Wellington: From Settler Colony to Garrisoned Sovereignty', NZJH, Vol.53, no.1, April 2019, pp.50-76.

Macdonald, Charlotte and Rebecca Lenihan, 'Paper Soldiers: The Life, Death and Reincarnation of Nineteenth-Century Military Files Across the British Empire', Rethinking History, Vol.22, no.3, 2018, pp.375-402.

McCaskill, Murray, 'The Gold Rush Population of Westland', New Zealand Geographer, Vol.12, no.1, April 1956, pp.32-50.

McDermott, Douglas, 'Touring Patterns on California's Theatrical Frontier, 1849-1859', Theatre Survey, Vol.15, no.1, 1974, pp.18-28.

Phillips, M. Scott, 'Rational Entertainment, Music Hall and the Nineteenth-Century British Periodical Press', Theatre History Studies, Vol.22, 2002, pp.195-213.

Pietsch, Tamson, 'Rethinking the British World', Journal of British Studies, Vol.52, no.2, April 2013, pp.441-463.

Senelick, Laurence, 'Signs of the Times: Outdoor Theatrical Advertising in the Nineteenth Century', Nineteenth Century Theatre and Film, Vol.45, no.2, November 2018, pp.173-211. 
Senior, Elinor, 'The British Garrison in Montreal in the 1840s', Journal of the Society for Army Historical Research, Vol.52, no.210, Summer 1974, pp.111-127.

Simpson, Adrienne, 'Putting Entertainment on the Map: The New Zealand Touring Circuits in 1874', ADS, Vol.26, April 1995, pp.153-176.

Traue, J. E., 'Reading as a "Necessity of Life" on the Tuapeka Goldfields in Nineteenth-Century New Zealand', Library History, Vol.23, no.1, 2007, pp.41-48.

Vineberg, Robert, 'The British Garrison and Montreal Society 1830-1850', Canadian Military History, Vol.21, no.1, Winter 2012, pp.3-16.

Wagner, Kim A., “'Treading Upon Fires': The 'Mutiny'-Motif and Colonial Anxieties in British India', Past \& Present, Vol.218, no.218, 2013, pp.159-197.

Warrington, Lisa, 'Archiving New Zealand Theatre - TADB, The Theatre Aotearoa Database', ADS, no.60, 2012, pp.223-228.

'Generally Regarded with a Lenient Eye: Amateur Theatre in Dunedin, 1862-1868', Journal of New Zealand Studies, no.15, 2013, pp.101-113.

—_We Are Amused: Theatre Comes to Dunedin, December 1861-April 1862', ADS, Vol.62, April 2013, pp.41-55.

Wevers, Lydia, 'Dickens in New Zealand', Literature Compass, Vol.11, no.5, 2014, pp.321-327.

Woollard, Jane, 'The Elasticity of Her Spirits: Actresses and Resilience on the Nineteenth-Century Colonial Stage', ADS, no.70, 2017, pp.7-34.

Worrall, David, 'Theatre in the Combat Zone: The Military Theatricals at Philadelphia, 1778', Linguaculture, Vol.2, pp.11-22.

\section{b) Books and Chapters}

Apperson, G.L., The Social History of Smoking, (London: Martin Secker, 1914).

Auerbach, Nina, 'Before the Curtain' in Kerry Powell (ed.), The Cambridge Companion to Victorian and Edwardian Theatre, (Cambridge: Cambridge University Press, 2004), pp.3-14.

Ballantyne, Tony, Moving Subjects: Gender, Mobility and Intimacy in an Age of Global Empire, (Urbana: University of Illinois Press, 2009).

Webs of Empire: Locating New Zealand's Colonial Past, (Vancouver: University of British Columbia Press, 2010).

Belich, James, Replenishing the Earth: The Settler Revolution and the Rise of the Angloworld, (Oxford: Oxford University Press, 2009).

Bender, Jill, The 1857 Indian Uprising and the British Empire, (Cambridge: Cambridge University Press, 2016). 
Benson, Eugene and L. W. Conolly, The Oxford Companion to Canadian Theatre, (Toronto: Oxford University Press, 1989).

Bigsby, Christopher and Don B. Wilmeath, 'Introduction' in Don B. Wilmeath (ed.), The Cambridge History of American Theatre, (Cambridge: Cambridge University Press, 1999), pp.1-19.

Bishop, Catherine, Women Mean Business: Colonial Businesswomen in New Zealand, (Dunedin: Otago University Press, 2019).

Booth, Michael R., Theatre in the Victorian Age, (Cambridge: Cambridge University Press, 1991).

Borsay, Peter, A History of Leisure: The British Experience Since 1500, (Houndmills: Palgrave Macmillan, 2006).

Bratton, Jacky, 'Mirroring Men: The Actress in Drag' in Maggie B. Gale and John Stokes (eds.), The Cambridge Companion to the Actress, (Cambridge: Cambridge University Press, 2007), pp.235-252.

The Making of the West End Stage: Marriage, Management and the Mapping of Gender in London, 1830-1870, (Cambridge: Cambridge University Press, 2011).

Brookes, Barbara, A History of New Zealand Women, (Wellington: Bridget Williams Books, 2016).

Cave, Richard Allan, 'Dion Boucicault' in Dennis Kennedy (ed.), The Companion to Theatre and Performance, (Oxford: Oxford University Press, 2010).

Coleman, Peter J., A Blot in the Statute Book: Imprisonment for Debt in New Zealand 1840-1990, (Wellington: NZHistoryJock, 2016).

Curry, Jane Kathleen, Nineteenth-Century American Women Theatre Managers, (London: Greenwood Press, 1994).

Davis, Adam, The Furthest Garrison: Imperial Regiments in New Zealand 1840-1870, (Solihull: Helion \& Company, 2019).

Davis, Jim and Victor Emeljanow, 'Victorian and Edwardian audiences' in Kerry Powell (ed.), The Cambridge Companion to Victorian and Edwardian Theatre, (Cambridge: Cambridge University Press, 2004), pp.93-108.

Davis, Tracy, The Economics of the British Stage, (Cambridge: Cambridge University Press, 2000). Actresses as Working Women: Their Social Identity in Victorian Culture, (London: Routledge, 1991).

Donohue, Joseph (ed), The Cambridge History of British Theatre: Volume 2: 1660 to 1895, (Cambridge: Cambridge University Press, 2004).

Downes, Peter, Shadows on the Stage: Theatre in New Zealand: The First 70 Years, (Dunedin: J. McIndoe, 1975).

Dunlap, William, A History of the American Theatre from Its Origins to 1832, (Champaign: University of Illinois Press, 2010).

Eckersall, Peter and Helena Grehan, The Routledge Companion to Theatre and Politics, (Milton: Taylor \& Francis Group, 2019). 
Edmonds, Jill, 'Princess Hamlet' in Vivien Gardner and Rutherford, Susan (eds.), The New Woman and Her Sisters: Feminism and Theatre 1850-1914, (Ann Arbor: University of Michigan Press, 1992), pp.59-76.

Eichin, Carolyn Grattan, From San Francisco Eastward: Victorian Theater in the American West, (Reno: University of Nevada Press, 2020).

Ell, Gordon, Gold Rush: Tales and Traditions of the New Zealand Gold Fields, (Auckland: Bush Press, 1995).

Engle, Ron, and Tice L. Miller (eds), The American Stage, (Cambridge: Cambridge University Press, 1993).

Featherstone, Ann, 'Tom Taylor' in Dennis Kennedy (ed.), The Companion to Theatre and Performance, (Oxford: Oxford University Press, 2010).

Flanders, Judith, Consuming Passions: Leisure and Pleasure in Victorian Britain, (London: HarperPress, 2006).

Gardner, Vivien, and Susan Rutherford (eds.), The New Woman and Her Sisters, (Ann Arbor: University of Michigan Press, 1992).

Goodman, David, Gold Seeking: Victoria and California in the 1850s, (St Leonard's: Allen \& Unwin, 1994).

Gould, Marty, Nineteenth-Century Theatre and the Imperial Encounter, (New York: Routledge, 2011).

Green, Anna, Cultural History, (London: Palgrave Macmillan, 2007).

Hall, Catherine, and Sonya Rose, At Home with the Empire, (Cambridge: Cambridge University Press, 2006).

Heinz, William F., Bright Fine Gold, (Wellington: Reed, 1974).

Huggins, Mike, Vice and the Victorians, (London: Bloomsbury, 2016).

Hurst, Maurice, Music and the Stage in New Zealand: A Century of Entertainment, 1840-1943, (Auckland: Charles Begg, 1944).

Hutchinson, Sam, Settlers, War and Empire in the Press, (London: Palgrave Macmillan, 2018).

Jarrett, Rudy, The Freedom to Smoke: Tobacco consumption and identity, (Montreal: McGill-Queen's University Press, 2005).

Kift, Dagmar, The Victorian Music Hall: Culture, Class and Conflict, (Cambridge: Cambridge University Press, 1996).

Laidlaw, Zoë, Colonial Connections, 1815-45: Patronage, the Information Revolution and Colonial Government., (Manchester: Manchester University Press, 2005).

Levine, Philippa, Gender and Empire, (Oxford: Oxford University Press, 2004).

Lippert, Amy K. DeFalco, Consuming Identities: Visual Culture in Nineteenth-Century San Francisco, (Oxford: Oxford University Press, 2018). 
MacKenzie, John (ed.), Imperialism and Popular Culture, (Manchester: Manchester University Press, 1986).

MacKenzie, John M., Popular Imperialism and the Military, (Manchester: Manchester University Press, 1992).

Massey, Doreen, Space, Place and Gender, (Minneapolis: University of Minnesota Press, 1994).

May, Philip Ross, Hokitika: Goldfields Capital, (Christchurch: Pegasus Press, 1964).

The West Coast Gold Rushes, (Christchurch: Pegasus Press, 1962).

McFeely, Deirdre, Dion Boucicault: Irish Identity on Stage, (Cambridge: Cambridge University Press, 2012).

Milling, Jane, and Peter Thomson (eds.), The Cambridge History of British Theatre; Volume 1:

Origins to 1660, (Cambridge: Cambridge University Press, 2004).

Moody, Jane, and Daniel O'Quinn (eds), The Cambridge History of British Theatre, 1730-1830, (Cambridge: Cambridge University Press, 2004).

Moody, Jane, 'Richard Brinsley Sheridan' in Dennis Kennedy (ed.), The Companion to Theatre and Performance, (Oxford: Oxford University Press, 2010).

Mountford, Benjamin, 'The Pacific Gold Rushes and the Struggle for Order' in Benjamin Mountford and Stephen Tuffnell (eds.), A Global History of Gold Rushes, (Oakland: University of California Press, 2018), pp.88-108.

O'Malley, Vincent, The New Zealand Wars Ngā Pakanga o Aotearoa, (Wellington: Bridget Williams Books, 2019).

O'Quinn, Daniel, 'Theatre and Empire' in Jane Moody and Daniel O'Quinn (eds.), The Cambridge Companion to British Theatre, 1730-1830, (Cambridge: Cambridge University Press, 2009), pp.233-246.

Olssen, Erik, A History of Otago, (Dunedin: John McIndoe Ltd, 1984).

Platts, Una, The Lively Capital, (Christchurch: Avon Fine Prints, 1971).

Powell, Kerry, 'Gendering Victorian Theatre' in Joseph Donohue (ed.), The Cambridge History of British Theatre Volume 2: 1660 to 1895, (Cambridge: Cambridge University Press, 2004), pp.352-368.

- (ed.), The Cambridge Companion to Victorian and Edwardian Theatre, (Cambridge: Cambridge University Press, 2004).

_ 'Victorian Theatre: Power and Politics of Gender' in Juliet John (ed.), The Oxford Handbook of Victorian Literary Culture, (Oxford: Oxford University Press, 2015), pp.675-685.

Women and Victorian Theatre, (Cambridge: Cambridge University Press, 1997).

Pullen, Kirsten, Actresses and Whores: On Stage and in Society, (Cambridge: Cambridge University Press, 2005). 
Richards, Jeffery, 'Drury Lane Imperialism' in Peter Yeandle, Katherine Newey, and Jeffery Richards (eds.), Politics, Performance and Popular Culture: Theatre and Society in NineteenthCentury Britain, (Manchester: Manchester University Press, 2016), pp.174-194.

Robinson, Jo, 'The Actress as Manager' in Maggie B. Gale and John Stokes (eds.), The Cambridge Companion to the Actress, (Cambridge: Cambridge University Press, 2007), pp.157-172.

Sarlós, Robert K., 'Performance Reconstruction: The Vital Link Between Past and Future' in Thomas Postlewait and Bruce A. McConachie (eds.), Interpreting the Theatrical Past: Essays in the Historiography of Performance, (Iowa City: University of Iowa Press, 1989), pp.198-229.

Schoch, Richard W., 'Theatre and Mid-Victorian Society, 1851-1870' in Joseph Donohue (ed.), The Cambridge History of British Theatre Volume 2: 1660 to 1895, (Cambridge: Cambridge University Press, 2004), pp.331-351.

Simpson, Adrienne, Opera's Farthest Frontier: A History of Professional Opera in New Zealand., (Auckland: Reed Publishing, 1996).

Slater, Michael, 'Douglas Jerrold' in Dennis Kennedy (ed.), The Companion to Theatre and Performance, (Oxford: Oxford University Press, 2010).

Stone, R.C. J., Young Logan Campbell, (Auckland: Auckland University Press, 1982).

Summerfield, Penny, 'Patriotism and Empire: Music-Hall Entertainment 1870-1914' in John Mackenzie (ed.), Imperialism and Popular Culture, (Manchester: Manchester University Press, 1986), pp.17-48.

Thomas, David, 'The 1737 Licensing Act and Its Impact' in Julia Swindells and David Francis Taylor (eds.), The Oxford Handbook of the Georgian Theatre, 1737-1832, (Oxford: Oxford University Press, 2014).

Tosh, John, A Man's Place: Masculinity and the middle-class home in Victorian England, (New Haven: Yale University Press, 1999).

Tosh, John Manliness and Masculinities in Nineteenth-Century Britain: Essays on Gender, Family and Empire, (New York: Pearson Longman, 2005).

Vince, R.W., 'Theatre History as an Academic Discipline' in Thomas Postlewait and Bruce A. McConachie (eds.), Interpreting the Theatrical Past: Essays in the Historiography of Performance, (Iowa City: University of Iowa Press, 1989), pp.1-18.

Warren, Robin O., Women on Southern Stages, 1800-1865: Performance, Gender and Identity in a Golden Age of American Theater, (Jefferson: McFarland, 2016).

Wevers, Lydia, Reading on the Farm, (Wellington: Victoria University Press, 2010).

Williams, Raymond, Keywords: A vocabulary of culture and society, (Oxford: Oxford University Press, 1985).

Wilmeath, Don B., and Christopher Bigsby (eds.), The Cambridge History of American Theatre, (Cambridge: Cambridge University Press, 1999). 


\section{c) Theses}

Appleton, Nicholas Ryan, 'Staging an Empire: How Late Victorian Theatre Represents Public Perceptions of the British Empire', MA thesis, University of Maryland, College Park, 2019.

Berkin, Nicole, 'Economies of Touring in American Theatre Culture, 1835 - 1861', PhD thesis, City University of New York, 2015.

Boutilier, Alex D., 'The Citadel on Stage: The rise and decline of garrison theatre in Halifax', MA thesis, Saint Mary's University, 2005.

Davis, Adam, 'The Imperial Garrison in New Zealand with particular reference to Auckland', PhD thesis, University of Luton, 2004.

Gleeson, Jean Clare, 'Owner Bound Music: A study of popular sheet music selling and music making in the New Zealand home 1840-1940', PhD thesis, Victoria University of Wellington, 2019.

Liebich, Susann, 'Connected Readers: Reading Practices and Communities across the British Empire, c.1890-1930', PhD thesis, Victoria University of Wellington, 2012.

Lucas, Heather, 'Square Girls: Prostitutes and Prostitution in Dunedin in the 1880s', BA(Hons) research essay, University of Otago, 1985.

Mitchell, Alexandra, 'Middle-Class Masculinity in Clubs and Associations: Manchester and Liverpool, 1800-1914', PhD thesis, University of Manchester, 2011.

Taylor, Dorothy Jean, 'Laura Keene in America 1852-1873', PhD Thesis, Tulane University, 1966. 